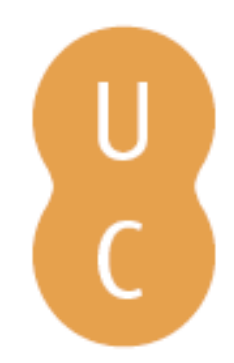

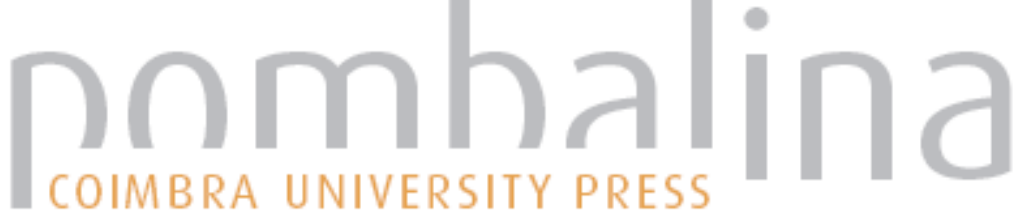

\section{Imprensa Estudantil Coimbrã}

Autor(es): $\quad$ Prata, Manuel Alberto Carvalho, ed. lit.

Publicado por: Imprensa da Universidade de Coimbra

URL

persistente:

URI:http://hdl.handle.net/10316.2/32277

DOI:

DOI:http://dx.doi.org/10.14195/978-989-26-0425-1_4

Accessed : $\quad$ 26-Apr-2023 08:52:00

A navegação consulta e descarregamento dos títulos inseridos nas Bibliotecas Digitais UC Digitalis, UC Pombalina e UC Impactum, pressupõem a aceitação plena e sem reservas dos Termos e Condições de Uso destas Bibliotecas Digitais, disponíveis em https://digitalis.uc.pt/pt-pt/termos.

Conforme exposto nos referidos Termos e Condições de Uso, o descarregamento de títulos de acesso restrito requer uma licença válida de autorização devendo o utilizador aceder ao(s) documento(s) a partir de um endereço de IP da instituição detentora da supramencionada licença.

Ao utilizador é apenas permitido o descarregamento para uso pessoal, pelo que o emprego do(s) título(s) descarregado(s) para outro fim, designadamente comercial, carece de autorização do respetivo autor ou editor da obra.

Na medida em que todas as obras da UC Digitalis se encontram protegidas pelo Código do Direito de Autor e Direitos Conexos e demais legislação aplicável, toda a cópia, parcial ou total, deste documento, nos casos em que é legalmente admitida, deverá conter ou fazer-se acompanhar por este aviso. 
Manuel Alberto Carvalho Prata

Coordenação

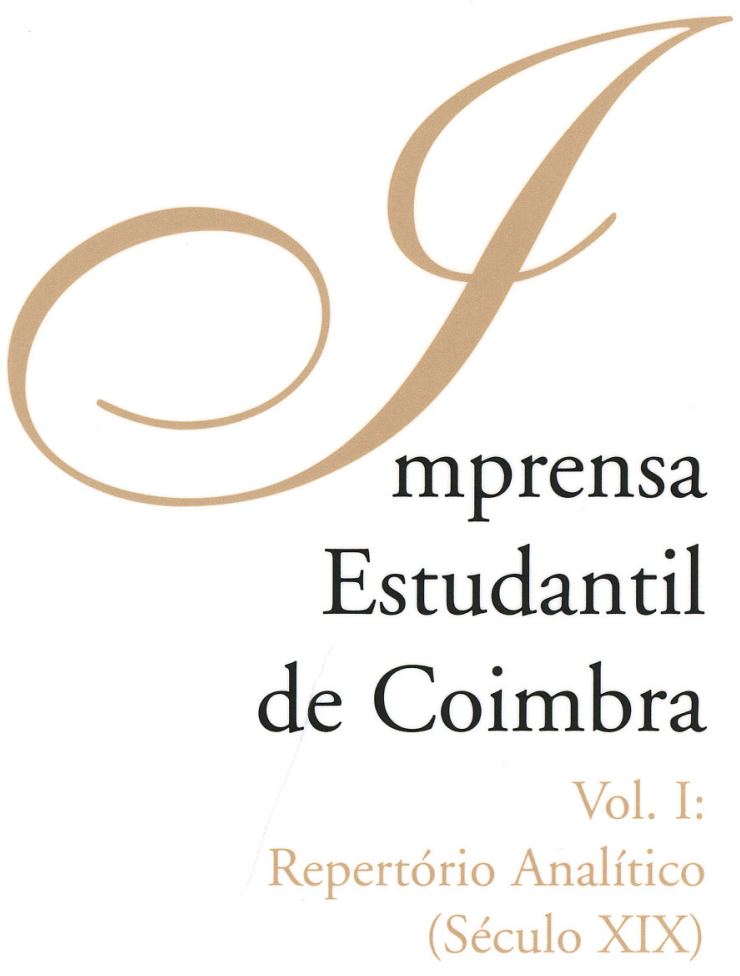

$\mathrm{Coimbra}$ - Imprensa da Universidade • 2006 


\title{
Imprensa Estudantil Coimbrã
}

Repertório Analítico

(Século XIX)

\author{
Vol. 1
}


(Página deixada propositadamente em branco) 


\section{1 - A ACADEMIA}

Semanário de Literatura

Coimbra, Imprensa da Universidade

1 Dezembro 1866 - 28 Fevereiro 1867

Responsável: F. da Silva Machado

Colaboradores: J. Lopes Praça, João de Deus, J. Simões Dias, Emídio Navarro, João Penha, M. Emídio Garcia, Teófilo Braga, Francisco Adolfo Coelho, F. de Medeiros, Serras da Conceição, Lopo Vaz de Sampaio e Melo, C. Andrade de Albuquerque.

Formato: 17, 5 x $27 \mathrm{~cm}$

Periodicidade: Semanal

Preço: Coimbra - 600 réis-trimestre

Província -650 réis-trimestre

Páginas: 96
Cotas:

BN: J. 147//1B.;

J. $841 / / 1 \mathrm{~B}$;

J. 2165P.

BGUC: $10-9-7$

BPMP: P-B-2165 [1]

BMC: GHC-2/5

\section{Objectivo}

«Os jornais de Coimbra são como os pirilampos - luminosos e rápidos. A luz que derramam não é tanta, que deslumbre; a rapidez com que desaparecem, essa sim espanta.

... A Academia não promete ir aos astros para não se perder. Nas faixas da humildade se envolve, e a humildade tem o direito à benquerença de todos.

Não arvora bandeira, porque a não tem; não se alista em Aerópagos, porque os não conhece; não representa os estudantes de Coimbra, porque não recebeu mandato.

Tem o nome de Academia, porque representa o trabalho e a boa vontade de alguns, para quem a capa e a batina ainda não deixaram de ser brazão de honra» (A Academia, n. ${ }^{\circ}$ 1, 1 de Dezembro de 1866, p. 1).

\section{Conteúdo}

Embora os objectivos não estejam claramente definidos, A Academia procura derramar luz, no sentido de uma melhor ilustração e instrução. 
Nos doze números que compõem a colecção, a estrutura é a mesma, quer quanto ao formato, quer quanto ao número de páginas em cada número. Nos artigos de $A$ Academia perpassam dois grandes domínios do saber: um diz respeito à História. Assinado por Manuel Emídio Garcia que nos fala da figura e da obra do primeiro ministro de D. José e do Liberalismo Português, em artigos intitulados «O Marquês de Pombal. Sua ciência, política e sistema de administração - ideias liberais que o dominam - plano e primeiras tentativas democráticas» e «Liberdade e Reacção», repartidos por vários números. Embora reconheça ter sido o Marquês de Pombal uma inteligência esclarecida e um hábil político, o que Emídio Garcia mais procura é fazer uma revivificação da imagem do estadista, em prol das necessidades de uma legitimação histórica do combate laico. Daí que ele tenha escrito: «O despotismo, a tirania de que se argue Pombal era calculada e imposta pelas necessidades, como o único meio de chegar à liberdade» (n. ${ }^{\circ}$ 10, p. 73, col.2).

Em «Liberdade e Reacção», procede a uma análise global do processo liberal, desde os primórdios até 1836, para concluir das vantagens do novo regime.

Ainda no âmbito da História, mas agora na especialidade de História da Educação, F. de Medeiros, no artigo «Esboço Histórico. Da instrução popular entre os povos antigos», depois de afirmar que «as leis da educação dum povo devem sempre conformar-se com o princípio fundamental do Estado» (n. ${ }^{\circ} 5$, p. 34, col. 2), dá-nos uma retrospectiva do que foi a instrução nos povos da antiguidade, nomeadamente: hebreus, egípcios, cartagineses, chineses, indianos, babilónios, persas, gregos (Esparta e Atenas) e romanos.

O segundo domínio tem a ver com a área da filosofia, onde Lopes Praça, no artigo «Apontamentos. Sobre o momento histórico da filosofia entre nós», repartido por diversos números, procura não «longas digressões sobre o movimento geral da filosofia», mas sobretudo em apontar "os traços suficientes para ligar os pensadores portugueses com os estrangeiros» (n. ${ }^{\circ}$ 1, p. 1, col. 1). Aqui se fala de Pedro da Fonseca, Sebastião do Couto, Baltazar Álvares e Manuel de Góis, este «um dos homens que mais concorreu para a muita celebridade do colégio conimbricense» (n. ${ }^{\circ}$ 10, p. 76, col. 1).

Já não com a mesma relevância, mas igualmente importantes são as áreas, da Economia e Finanças e da Filologia. Relativamente àquelas, Emídio Navarro, no artigo «A Liberdade e o Monopólio», discorre sobre crises monetárias e bancárias, liberdade de trabalho e liberdade de associação, monopólio bancário e liberdade de crédito. 
No campo da Filologia, Francisco Adolfo Coelho, em «Diversões Filológicas», depois de algumas considerações sobre a matéria, lamenta o nosso atraso, porque «raríssimas obras filológicas têm sido publicadas entre nós» (n. ${ }^{\circ}$ 7, p. 52, col. 2).

De assinalar a secção permanente ou quase permanente de «Revista», onde se noticiam acontecimentos vários da vida académica e citadina e se fazem apreciações de obras dadas à estampa.

Completam esta publicação algumas poesias e um romance.. 


\section{2 - ACADEMIA}

Jornal da Classe Académica Conimbricense (1)

Coimbra, Casa Minerva(2)

1 Dezembro 1878 - 22 Maio 1879
Cotas:

BN: J.2088//12M.

BGUC: -

BPMP: -

BMC: GHC-21/1

Redactores: Luís de Figueiredo Guerra, Marco de Avelar, Vasco Moniz, Serrão Moniz, Augusto Ramos, Afonso Vargas, Rebelo Alves Correia e outros.

Formato: $27,5 \times 42$

Periodicidade: Semanal

Preço: Avulso - 40 réis • Semestre $-1 \$ 200$ réis

Páginas: 4

\section{Objectivo}

«Aparece pela primeira vez à luz do dia o nosso esperançoso jornal, orgão dedicado da classe académica e obreiro incansável da reorganização social. Vem afirmar, no vasto campo da imprensa, que a classe académica forceja por acompanhar o movimento ascendente e progressivo dos tempos actuais - a evolução crescente do pensamento humano. No esplendoroso século dezanove, o século das grandes conquistas e dos ousados cometimentos, seria um crime cruzar os braços, uma baixeza permanecer na indiferença.

Cada um vista as armas que melhor souber manejar e lute... Estamos no período da antítese, no combate incessante das ideias, na luta porfiada dos princípios.

Nos vastos campos da actividade humana sopra rijo o vento do progresso. A humanidade avança pelo impulso poderoso da ideia nova e pelos esforços sobrehumanos dos apóstolos da civilização.

Nós, jovens académicos, educados num meio saturado das mais rasgadas aspirações, empunhemos também o alvião da reforma, para na justa medida

\footnotetext{
(1) A partir do n. ${ }^{\circ}$, de 19 de Janeiro de 1879 , o subtítulo desaparece.

(2) Alguns números foram, depois, editados na Imprensa Literária.
} 
das nossas forças, derrocarmos o antigo edifício social, que se nos afigura velho e escalavrado, ameaçando ruínas.

E neste intuito faremos guerra crua e sem quartel ao erro que invade os crâneos e aos privilégios que ofendem o Direito.

Pugnaremos pela causa justa e santa da Verdade e do Bem. Não nos incutem medo as iras dos poderosos, nem nos empana a vista o brilho, sedutor das vestes da realeza.

...Vá também cada um de nós à busca do seu ideal; o perfeito é o limite para que devem tender os nossos esforços. Dissipemos as trevas que ainda hoje entenebrecem milhares de inteligências... Entremos todos de mãos dadas no banquete em que comungam todos os povos da Europa: sigamos a corrente que agita o século, e que transforma o mundo» (Academia, n. ${ }^{\circ}$ 1, Coimbra, 1 de Dezembro de 1878, pp. 1-2).

\section{Conteúdo}

Organizada por um conjunto de estudantes, adeptos das ideias positivistas e das ideias republicanas, esta publicação pretende ilustrar e instruir, revolucionar mentalidades e, consequentemente, contribuir para uma reforma da sociedade.

Nos dezanove números que compõem a colecção, este periódico mantém, sensivelmente, a mesma estrutura. Embora sem títulos, na grande maioria dos casos, a primeira página é, normalmente, preenchida com um artigo de fundo, onde se abordam, preferencialmente, questões de ordem política. É nestes editoriais que a publicação melhor se define, pelo menos, politicamente. Aqui se criticam o rei e o regime monárquico, quando se afirma que «o rei constitucional é uma recordação venerável do passado, é a inscrição dum templo antigo colocada na fronteira de um edifício moderno" (n. ${ }^{\circ} 7$, p. 2 , col. 1) e que «as castas e as distinções de nascimento são velharias absurdas» (n. ${ }^{\circ}$ 2, p. 1, col. 1) e se louvam «a ideia republicana, os princípios democráticos que são a síntese das leis as mais justas, das aspirações as mais cordatas e dos sentimentos os mais puros» (n. ${ }^{\circ}$ 17, p. 1, col. 3), ou, então, os esforços de Gambeta e o movimento republicano francês, que denominam "cabeça pensante do mundo moderno" (n. ${ }^{\circ}$ 8, p. 1, col. 2), aos quais «os estudantes não podiam deixar de exprimir... adesão ao acto mais solene da vida de um povo» (Idem). E porque, no contex- 
to do positivismo e em matéria política, o exemplo é importante, salienta-se, também, o artigo intitulado "Victor Hugo", a quem chamam «o maior poeta deste século, o cantor... dos direitos do povo, o apóstolo da Humanidade» (n. ${ }^{\circ} 11$, p. 1, col. 1).

Dado o tipo de publicação e os objectivos que procura, os vários artigos e textos inseridos em Academia abarcam domínios múltiplos do saber. Neles se reflecte, se tecem considerações e se explanam teorias e pontos de vista sobre temáticas e questões como:

- História: cultura dolménica; medição do tempo - calendários (maometano, judaico, juliano e gregoriano); os árabes na Península Ibérica; o terceiro-estado - sua evolução e importância; os cristãos-novos; a colonização da Ilha Terceira, nos Açores; a escravatura; a data de 1 de Dezembro de 1640; as relações entre Portugal e a Inglaterra (Tratado de Methoween, a acção do Marquês de Pombal, o governo de D. Maria, das invasões francesas a 1820); a pessoa e as virtudes de D. Pedro V.

- Política e Sociedade: afirmação e defesa das ideias republicanas; críticas à monarquia e seus princípios; críticas à sociedade actual (a constatação do nosso atraso, o indiferentismo, o socialismo); críticas também à Casa de Bragança; a organização judicial; condição social da mulher; o problema da roda e dos hospícios; o comunalismo.

- Questão Social: a propriedade (origens - a posição socialista e outras teorias); o trabalho infantil (criança, educação e sociabilidade); a criança e a oficina; a necessidade de uma legislação adequada - exemplos de países europeus, a situação portuguesa, onde, nesta matéria, é «tudo silencioso e estéril» (n. ${ }^{\circ}$ 7, p. 3, col. 2).

- Academia: conflitos académicos: futricas, as forças policiais e a posição assumida pelo Governo Civil de Coimbra.

No domínio de uma cultura utilitária e prática, de referir os seguintes artigos: «Civilização das Formigas»; «Modo de conservar as rosas»; «As marés» e «Estudos Arábicos», onde se fala dos caracteres cúficos e moedas hispano-árabes.

A existência ainda de um folhetim, poesia, apreciações de representações teatrais e alguma publicidade, nomeadamente a livros dados à estampa como, por exemplo, Rumores Vulcânicos de Teixeira Bastos, onde se sente, na apre- 
ciação que lhe fazem, «o vigoroso espírito da revolução e o magnífico influxo da liberdade» (n. ${ }^{\circ}$ 3, p. 4, col. 3) e Aurora da Revolução de Angelina Vidal.

Completa-se este periódico com duas secções praticamente permanentes: «Noticiário», onde se dão a conhecer notícias várias sobre assuntos múltiplos e «Boletim Universitário. Faculdade de Direito». 


\section{3 - A ACADEMIA}

Coimbra, Minerva Central

14 Janeiro 1897 - 8 Fevereiro 1897
Cotas:

BN: -

BGUC: O.S. 1039

BPMP: -

BMC: GHC.-19/3

Director: Mário B. Henriques da Silva;

Administrador: Manuel Jardim; Ulisses da Veiga

Mateus

Redactores: Ulisses da Veiga e M. da V. Mateus

Secretário: Luís Madureira

Formato: 17 x $23 \mathrm{~cm}$

Periodicidade: Quinzenal

Preço: 40 réis mensais

Páginas: 4

\section{Objectivo}

«O nosso jornal tem por fim mimosear os nossos leitores com um bocadinho de distracção; não tratando de política, porque não nos achamos competentes para isso, mas refutando ou aceitando, com voz unânime, as acções honestas ou vis, em que acharmos conveniente meter-nos e também nos acharmos competentes.

Somos um grupo de rapazes que tivemos ao mesmo tempo a mesma ideia e que, receando ainda executá-la, contudo a pusemos em prática, sem nos importarmos com o futuro» (A Academia, n. ${ }^{\circ}$ 1, Coimbra, 14 de Janeiro de 1897, p. 1, col. 1).

\section{Conteúdo}

É um pequeno jornal, composto a duas colunas, que, segundo os seus redactores, alunos do liceu, tem como objectivo fundamental levar aos leitores um pouco de distracção e alguma informação. E, de facto, assim é. Em textos muito simples e muito curtos dão-se a conhecer: notícias várias (de personalidades, organismos académicos, saraus, publicações, novos poetas, etc), contos, história (as Guerras Púnicas). 
A existência ainda de alguma poesia, folhetins ( $O$ Brasileiro Soares de Luís de Magalhães e a Indiana de Tomás Ribeiro), de uma secção «Para Rir», com piadas e chalaças, e outra de «Publicações», onde se referenciam as publicações recebidas. 


\section{4 - A ACADEMIA DE COIMBRA}

Ciências, letras e factos

Coimbra, Imprensa Literária

3 Março 1886 - 8 Agosto de 1886
Cotas:

BN: J.200/3B

BGUC: 0.S.1023

BPMP: -

BMC: GHC-2-S

Redactores: Ângelo Ferreira, Eduardo Pires de Lima, Francisco Bastos, João de Caires, João da Mota Gomes, Silvestre Falcão

Colaboradores: Acácio da Fonseca, António Fogaça, Sanches da Gama, F. Rodrigues de Gusmão Júnior, J. Silva Cordeiro, Júlio de Lima Duque, Paulo Franco

Formato: $21,5 \times 27,8 \mathrm{~cm}$

Periodicidade: Semanal

Preço: Avulso: 40 réis • Assinatura: 12 meses - 400 réis

Páginas: 8

\section{Objectivo}

«O periódico que ora oferecemos ao público intervem em um momento gravíssimo da vida académica, e quando mais coesa vai a luta entre os defensores do retrocesso e o grupo que há dias encetou um período de renascimento para a nossa academia, chamando-a a associar-se às ideias mais grandiosas que o desenvolvimento da civilização for patenteando e incitando-a a afirmar perante o país que não está de todo exausta a força que outrora a recomendou à geral admiração. E a Academia de Coimbra vem em defesa dessa ideia, lançada à apreciação pública com a mais sincera das convicções e com o entusiasmo que naturalmente acompanha a actividade mental da mocidade.

A imperiosa necessidade de semelhante empreendimento era de há muito reconhecida pelos espíritos mais independentes, impressionados a cada passo pela decadência a que chegou uma classe que nem sequer já tem força para nobilitar-se na sustentação das suas elevadas tradições...

A nova folha abrangerá todos os ramos da actividade intelectual: a modesta investigação científica e a despretenciosa obra literária, como a apreciação crítica dos factos mais importantes da vida académica. Não nos domina a pretensão de uma completa originalidade em nossos estudos científicos; antes nos limitaremos a afirmar em humildes ensaios a nossa inteira adesão aos princípios de 
ciência que o século proclama como as suas mais brilhantes conquistas. Afastar-se-ão preferências por determinadas escolas literárias, porque o nosso periódico, sendo especialmente destinado a mostrar ao país que a presente geração académica não são de todo indiferentes as lutas travadas lá fora no terreno da discussão artística, carece de apresentar composições demonstrativas do modo como entre nós se estudam e compreendem os variados sistemas literários. Excluiremos entretanto o radicalismo artístico, a lírica sentimentalidade como o realismo desbragado; não porque nos falte coragem para a luta, senão porque desejamos imprimir à nova folha a harmonia necessária à efectivação das nossas aspirações.

Eis o nosso programa... (A Academia de Coimbra, n. ${ }^{\circ}$ 1, Coimbra, 3 de Março de 1886, pp. 1-2).

\section{Conteúdo}

Como refere nas palavras que lhe servem de apresentação, esta revista estudantil, defensora dos ideais positivistas, procura desenvolver no seio da academia o culto das novas ideias, lutando assim contra uma certa apatia intelectual que se fazia sentir.

A estrutura interna desta publicação é a mesma ao longo dos seus doze números, quer no formato, quer no número de páginas de cada um. A existência também de uma secção permanente, intitulada «Ecos da Porta Férrea», onde se dá conta de acontecimentos vários da vida académica, alguns deles acompanhados de uma certa apreciação crítica. É o caso, entre outros, das «demasiadas familiaridades» que o Prof. de Química tem com os seus alunos, pelo que a «aula não é desde muito um modelo de socego, atenção e respeito» (n. ${ }^{\circ} 5$, p. 8 , col. 2); críticas também para folhetos e ideias que correm na Academia, nomeadamente aos novos poetas e prosadores, a quem chamam de «os épicos de água doce» (n. ${ }^{\circ} 1$, p. 8, col. 1).

Nos artigos de A Academia de Coimbra perpassam dois grandes temas: o debate em torno da influência que o cristianismo teve na abolição da escravatura. Trata-se de um conjunto de artigos, repartidos por vários números, da autoria de Eduardo Pires de Lima e Pedro Nogueira; conscientes das virtudes da nova ciência e fazendo a apologia do método positivo, o outro centra-se em reflexões sobre problemas vários da sociedade e do conhecimento científico. 
Num desdobramento temático mais estreito, é possível identificar questões como:

- Política e Sociedade: o pensamento político de Herbert Spencer; Ordem, Progresso e viver para os outros versus Liberdade, Igualdade e Fraternidade; a base falsa da nossa representação política; poder executivo e poder legislativo; a questão do sufrágio, como e por quem deve ser exercido; crise e mudança social;

- Ciência e Sociedade: Economia e Finanças - tributação e princípios gerais sobre a classificação de impostos; classificação dos impostos, por diversos autores e sua apreciação crítica; Ciências Naturais - Geologia: considerações acerca da classificação geológica; Zoologia - unidade e diversidade; consanguinidade, casamento e jurisprudência;

- Educação: Os jesuítas em Coimbra e sua acção.

Para além de um conjunto apreciável de poemas e do anúncio das publicações recebidas, completam esta revista a publicação de documentos relativos aos seguintes factos: mensagem que os estudantes de Direito enviaram, em 1859, a António Luís de Seabra, por causa da conclusão do projecto do Código Civil e resposta que o ilustre jurista lhes retribuiu; mensagem que a Academia de Coimbra enviou ao Dr. Júlio da Gama Pinto, professor de Medicina na Universidade de Heidelberg. 


\section{5 - O ACADÉMICO}

Publicação Mensal Científica e Literária

Coimbra, Imprensa da Universidade

Março de 1860 - Maio de 1860
Cotas:

BN: J.397B.; J.1659//2V.; P.P. $18005 \mathrm{~V}$.

BGUC: 10-9-7

BPMP: P-B-2605

BMC: G.H.C-20/1

Redactores: João de Deus Ramos, Eduardo José Coelho, Antero de Quental, Eugénio de Barros Ribeiro, Alberto da Cunha Sampaio, Alberto Teles de Ultra-Machado, Francisco Fernandes de Guimarães Fonseca, Severino de Sousa Azevedo, José Maria da Cunha Seixas

Formato: $18,5 \times 26,8 \mathrm{~cm}$

Periodicidade: Mensal

Preço: Avulso: 240 réis • Ano: $1 \$ 800$

Páginas: 96

\section{Objectivo}

«Quem do escasso património que possue reparte com o seu irmão - faz, sem dúvida, uma obra meritória aos olhos de Deus, e aquista o louvor da sua consciência...

O Académico dá em prol da sua boa acolhida a ideia de abraçar em seu grémio as santas aspirações da geração nova, tendentes a facultar a instrução ao povo e a regenerá-lo, afim que ele consiga o seu virtuoso destino, o de não ser reputado como uma classe ínfima, porém como a classe primeira e verdadeiramente única, aspirações e desejos estes, que tanto enobrecem a época em que vivemos, e que são incontestavelmente o timbre mais glorioso do século dezanove.

Ora, para cumprir esta missão caridosa e profícua, não se tornam essenciais grandes recursos de talento extraordinário; basta uma vontade enérgica e apurada no trabalho, e um coração dedicado com todas as veras à liberdade dos que sofrem.

E essa vontade e esse coração havemos nós, porque desejamos o grande dia da «igualdade para todos» e conhecemos que não se pode chegar lá sem o aperfeiçoamento moral de todos. 
Se, como de facto, não conseguirmos muito, resta-nos a consolação de cooperarmos com os outros que mais valeram; e se no servir a pedra para o grande edifício da civilização comum, não teremos de recriminar-nos pela nossa inactividade» (O Académico, n. ${ }^{\circ}$ 1, pp. 5-6).

\section{Conteúdo}

Trata-se de uma pequena publicação, que não foi além do fatídico n. ${ }^{\circ} 3$, e que, segundo nos dizem os seus responsáveis, visa contribuir, fundamentalmente, para a educação e instrução do povo, no sentido de uma maior liberdade e emancipação de todos. Diga-se, no entanto, que estes objectivos não se inscrevem, à semelhança do que fazem outros periódicos, no âmbito materialista do século. Antes pelo contrário. Reconhecendo-se a existência de uma certa corrupção e imoralidade a alastrar por quase todas as classes sociais, que «o espírito sente-se desfalecer e ceder o passo às ovações pomposas da matéria» (n. ${ }^{\circ} 1$, p. 8) e, citando ainda o Evangelho, onde se afirma que «nem só de pão vive o homem, mas de toda a palavra de Deus», aquela aposta centra-se, essencialmente, num esforço tendente a «mostrar que, acima de grosseiros interesses, se alteia pura sempre e altiva a ideia de imortalidade, e que esta ideia deve dominar as acções humanas, dando-lhes uma direcção mais espiritual e sublime» (Idem, p. 10), porque o homem é filho dilecto de Deus. Pretende-se, assim, tornar o homem mais homem.

Nos artigos de $O$ Académico transparece uma relativa preocupação social e moral. Em «Alvitres às classes laboriosas. Caixas Económicas» e «A Economia política, o pauperismo e o socialismo» tecem-se considerações, não só sobre problemas práticos do quotidiano, mas também sobre modelos sociais. Defende-se a criação de caixas económicas como sendo «a bolsa onde o pobre depõe com confiança economias penosamente adquiridas» (n. ${ }^{\circ}$ 1, p. 29) e, citando exemplos estrangeiros e portugueses, apontam-se maneiras de evitar a pobreza. Entre outras, uma aposta no desenvolvimento das Associações de Socorros Mútuos.

Fazendo a distinção entre verdadeira e falsa ciência e identificando esta com o socialismo, repudia-se este, porque «agasta-se, irrita-se ao ouvir só pronunciar a palavra desigualdade, e, sobre-elevando-se ao próprio Deus, cria, em seus delírios reformistas, uma sociedade fantástica, artificial, impossível» (n. ${ }^{\circ}$ 2, p. 38). 
Em «Esbocetos biográficos» faz-se a apologia dos grandes homens, como o Infante D. Henrique, «cujas vidas foram uma aspiração constante para o bem da sua pátria..., um sintoma certo do progresso desse povo e da sua moralização» (n. ${ }^{\circ} 1$, p. 25).

A temática feminina e, consequentemente, a educação da mulher estão igualmente presentes, no artigo "A mulher e a ciência». A concepção que aqui se explana de mulher é uma concepção de algum modo conservadora. Reconhece-se que existe «entre a mulher e a ciência uma antipatia, um como divórcio natural» (n. ${ }^{\circ}$ 1, p. 31). Constata-se, também, que mulheres houve, como Madame Sand, Stael, Sevigné e outras, que dedicaram às ciências o seu melhor e, por isso, «a história presta-lhes verdadeiro culto de respeito e gratidão» (Idem).

Conclui-se, no entanto, que este número é bastante diminuto, sinal seguro e prova evidente "que a natureza as criou para outro fim - para o amor... e parece-nos que a mulher conquistada pela ciência, é perdida para o amor» (Idem, p. 32).

Completam esta publicação poesias várias, uma descrição da serra de Sintra e seu palácio e o artigo intitulado «O jornal», onde se evidencia a importância que a imprensa, sobretudo o jornal, tem na educação e ilustração de um povo. Chamando ao jornal «o livrinho popular» (n. ${ }^{\circ} 3$, p. 77 ), ao povo «civiliza-o e instrue-o» (Idem, p. 76). 


\section{6・ ALBUM LITERÁRIO}

Jornal Literário e Noticioso

Coimbra, Imprensa da Universidade

5 Janeiro 1866 - 25 Março 1866
Cotas:

BN: J.239//5B.jJ.313//5P.

BGUC: $10-5-18$

BPMP: P-A-1008

BMC: GHC-4-S

Director: Manuel Fernandes Margalho

Colaboradores: J. Simões Dias, Martins de Carvalho, Avelino Calisto, J. Ferreira Machado, J. J. Sousa Cavalheiro, A. Ferreira de Freitas, J. C. Aguiar, Lopes Praça, Amélia Jany, Henrique de Macedo, Costa Goodolfim, António Xavier Sousa Cordeiro, José Martins Duarte Júnior

Formato: $16 \mathrm{x} 22 \mathrm{~cm}$

Periodicidade: Trimensal

Preço: Ano - 1\$200 - Coimbra • $1 \$ 440$ - Província

Páginas: 72

\section{Objectivo}

«O Album Literário desenrola hoje a bandeira da sua existência ao sol majestoso da civilização.

Hoje que por todos os ângulos da humanidade se ostenta brilhante a luz do progresso, e que ela parece haver-se difundido por todas as camadas da sociedade, era para lastimar que a mocidade conimbricense não tomasse o seu lugar nos debates civilizadores e ostentasse em toda a sua plenitude os recursos de que dispõe, prestando assim homenagem às ideias do século e curvando-se ante o esplendor do progresso humano...

Desde que a luz evangélica se difundiu por toda a superfície do globo... e que no Gólgota se hasteou o pendão sacro-santo do progresso, as lutas terríveis da matéria cederam seu lugar às lutas luminosas do espírito...

O Cristo da religião é ainda o mesmo Cristo da civilização... A imprensa... é hoje... a primeira alavanca do progresso, o motor principal da civilização humana...

Não era muito que a mocidade apresentasse à sociedade um jornal seu... Não pode ela proferir seu veredictum sobre os intrincados problemas..., mas pode apresentar sua opinião, à custa de seus estudos... Avante pois! Estudai, 
que é com o estudo, que se decidem as mais elevadas questões sociais; estudai que é com o estudo e pelo estudo que hoje o homem consegue o seu fim.

Nesse intuito esforçamo-nos por levar a efeito a publicação desta folha, publicação que, despida de todo o interesse material, só procura o aperfeiçoamento moral da mocidade, só aspira à sua ilustração» (Album Literário, n. ${ }^{\circ}$ 1, 5 de Janeiro de 1866, pp. 1-2).

«A publicação do Album Literário é um brado forte, é um incitamento nobre à mocidade, no intuito de a fazer tirar do estado de inércia e abatimento, e ocupar o lugar que lhe compete nas lutas partidárias da ciência, nas fileiras da literatura, tão povoadas de inteligências robustas, tão cheias de génios transcendentes» (p. 8).

\section{Conteúdo}

Constatando a existência de alguma inércia cultural entre a juventude estudantil e reconhecendo que à imprensa cabe um papel fundamental na divulgação das ideias e do progresso, esta publicação procura, face aos desafios dos tempos, que a mocidade académica reflicta sobre os mais diversos e variados problemas, para, depois, apontar sugestões e dar a conhecer as suas opiniões. Album Literário afirma-se, assim, não só como um espaço de reflexão, mas também de cultura e informação.

A colecção completa desta publicação abrange nove números, constituindo um volume com 72 páginas e onde todos os números apresentam a mesma estrutura.

Para além de textos de carácter literário, em prosa e verso, e do ensaio «A propósito do Fausto» de Goethe, da autoria de Simões Dias, nos artigos de Album Literário perpassam dois grandes temas: o mais importante, até porque nos ajuda a situar ideológica e politicamente a publicação, tem a ver com os reflexos que as novas ideias do século estão a provocar na sociedade; o segundo diz respeito a um conjunto de informações sobre o Japão e a vida dos seus habitantes, nomeadamente, religião, justiça, agricultura, comércio e indústria. Numa referência ao carácter dos japoneses diz-se: «Sofrem as maiores injúrias sem que mostrem a menor alteração, todavia em ponto de honra são assás sensíveis e melindrosos» (n. ${ }^{\circ}$ 9, p. 72, col. 2). 
Relativamente ao primeiro, tratam-se, fundamentalmente, duas questões: o casamento civil e a problemática da revolução. Fazendo eco de um protesto (que se publica no n. ${ }^{\circ}$ 1, p. 5), liderado por mulheres, levado a cabo em Lisboa, em 8 de Dezembro de 1865, contra o casamento civil, o director desta publicação não só manifesta o seu apoio a tal iniciativa, como também combate a doutrina que lhe é inerente, a qual apelida de «ímpia e imoral» (n. ${ }^{\circ}$ 5, p. 33, col. 1). O combate ao casamento civil advém, de entre outras razões, porque «é anti-religioso, e o que está em oposição com os princípios da nossa religião não pode ser progressista, nem merece as honras de civilizador» (n. ${ }^{\circ} 6$, p. 42, col. 1) e, como católicos, «porque à face dos princípios dogmáticos da nossa fé o não podemos abraçar sem renegarmos nossas crenças» (n. ${ }^{\circ}$ 7, p. 49, col. 1). Por isso, à lei do casamento civil chama-lhe «o maior aborto do nosso século» (n. ${ }^{\circ}$ 5, p. 33, col. 1).

Evocando revoltas do General Prim, em Espanha, nenhuma simpatia, também, pela revolução, porque ela não só «derruba dos tronos os monarcas legítimos» (n. ${ }^{\circ} 3$, p. 20, col. 1), e faz a "substituição destes pelos governos eleitos popularmente» (n. ${ }^{\circ}$ 4, p. 29, col. 1), mas também porque a revolução é «inimiga da ordem social, da prosperidade das nações» (n. ${ }^{\circ}$ 3, p. 20, col. 2) e, sob o ponto de vista religioso, é «a proscrição do catolicismo de sobre a face da terra... é protestantizar os povos» (n. ${ }^{\circ} 4$, p. 29, col. 2). Referindo-se à tríade Liberdade, Igualdade e Fraternidade não deixa de sustentar que se trata de palavras «melífluas, mas venenosas» (n. ${ }^{\circ} 3$, p. 20, col. 1).

Completa-se esta publicação com uma secção permanente «Revista», onde se dão notícias e informações diversas sobre acontecimentos vários, não só do país, mas também do estrangeiro. 


\section{7 - A ALVORADA}

$\begin{array}{ll}\text { Revista Literária e Política } & \text { Cotas: } \\ \text { Coimbra, [s.1.] } & \text { BN: - } \\ 6 \text { Abril 1896 - 23 Abril 1896 } & \text { BGUC: - } \\ & \text { BPMP: - } \\ & \text { BMC: GHC-19/1 }\end{array}$

Director: Joaquim Gomes

Editor: Adelino Areosa

Redactores: Joaquim Gomes, Artur Xavier

Formato: 13 x $21 \mathrm{~cm}$

Periodicidade: Quinzenal

Preço: Avulso - 30 réis $\bullet$ Assinatura -50 réis

Páginas: 8

\section{Objectivo}

«...visto que não nos foi possível apresentá-la por agora impressa como desejávamos, aparece Alvorada, revista modestíssima, sem aspirações que não sejam as de fazer as nossas primeiras armas em literatura e política simultaneamente traduzindo a nossa indignação perante a degringalade que ameaça alastrar-se consideravelmente pelo país e de que é, e será origem a monarquia com os seus aulicos: juntando assim a nossa débil voz ao imenso clamor que de todos os lados começou a ouvir-se, mercê da luz que alguns espíritos conscienciosos, ilustrados e cultos vão fazendo no espírito do povo que já vai compreendendo, ainda que tarde, que, se não quer continuar a ser roubado, mais desprezadas as regalias que têm direito a fruir, porque paga... mais tem de suplantar esta monarquia inepta que outrora cheia de esplendor não passa hoje de uma lamparina de azeite que o sopro mais leve pode apagar» (A Alvorada, n. ${ }^{\circ}$ 1, Coimbra, 6 de Abril de 1896, pp. 1-2).

\section{Conteúdo}

Esta pequeníssima revista, organizada e redigida por dois estudantes, pretende afirmar-se como um espaço de criação e produção literária e, simultaneamente, de experiência política. O discurso utilizado é simples e directo. 
A estrutura interna de $A$ Alvorada é essencialmente a mesma nos dois números que compõem a colecção. Para além do mesmo formato e número de páginas, a existência, também de uma secção permanente - «Crónica». De referir, ainda, que até na própria capa de cada um dos números aparece transcrita a seguinte quadra: «Surge o arrebol: alvorece/Começa a terra a acordar/A vaga luz que aparece/Convida-nos a trabalhar».

A produção literária traduz-se na linguagem rítmica dos versos. Politicamente, esta revista revela-se simpatizante do republicanismo. Para além das palavras que lhe servem de Introdução e definem os seus objectivos, é, essencialmente, no artigo intitulado «A nossa atitude» que esta publicação e os seus responsáveis se revelam. É aqui que rejeitam, categoricamente, toda e qualquer cooperação dos republicanos com os progressistas e regeneradores, porque estes «constituem duas facções ávidas de ouro e de poder; por isso nós, republicanos, não devemos auxiliar facções que trabalham para um mesmo fim resguardando a monarquia» (n. 2 , p. VIII).

Simpatia pelos ideais da liberdade e dos povos, também, na defesa que fazem da independência de Cuba: «Seria bom, portanto, que a Espanha concedesse a autonomia a Cuba, que a sua causa é justa» (Idem, p. VIII).

Como o próprio nome sugere, na secção «Crónica» dá-se conta do que vai acontecendo no país e, fundamentalmente, em Coimbra: horário de trabalho para a construção civil, a falta de chuva que está a causar prejuízos na agricultura e a morte do estudante Hilário, esse «estranho boémio» que deixou «um vácuo nas nossas almas sentimentais» (n. ${ }^{\circ}$ 2, p. III) são alguns dos assuntos focados. 


\section{8 - O AMIGO DO ESTUdO}

Jornal Bimensal

Coimbra, Imprensa da Universidade

1867

Responsável: A. M. Seabra de Albuquerque

Colaboradores: A. Filipe Simões, F. Guimarães

Fonseca, F. A. Coelho, Amélia Janny, J. C. Preto

Pacheco, V. de Meireles, J. Frederico Laranjo,

Severino de Azevedo, Luís Carlos, Alexandre da

Conceição, A. A. da Fonseca Pinto, M. da Costa

Alemão, J. Simões Dias, Antero A. de Almeida,

João Penha, D ${ }^{\text {a }}$ Ana Maria do Carmo Pessoa, M.

de P. da Rocha Viana

Formato: $18,5 \times 27,5 \mathrm{~cm}$

Periodicidade: Bimensal

Preço: Trimestre - 240 réis

Páginas: 84
Cotas:

BN: J.965//8P.

BGUC: $10-5-19$

BPMP: -

BMC: GHC-20/1

\section{Objectivo}

«Se é difícil assentar a pena na primeira página de um livro, não é menos melindroso escrever a primeira linha de um jornal. Pode dizer-se com afoiteza o fim do primeiro, mas nem sempre exporemos seguros a mira do segundo...

O livro é monárquico, o jornal república. Aquele, pequeno ou grande, subordina-se a um só sentimento, e raro se salva da monotonia. Este tem a variedade por divisa, e agrada sempre. Alí a uniformidade e aqui a liberdade formam um contraste singular. O livro é palaciano de natureza, e busca o agasalho dos gabinetes. O jornal cabe em toda a parte, e amolda-se a todas as condições. Um poderá ser o catedrático da ciência, mas o outro é com certeza o apóstolo da instrução do povo.

O Amigo do Estudo resume no seu título a síntese das suas aspirações. É uma oficina de trabalho para os que tratam letras; e todo o operário tem aqui seu préstimo neste lidar incessante. A bandeira que hasteamos tem um moto que dispensa programas e vale por longas considerações. Ao assentarmos nossos modestos arraiais neste vasto acampamento da imprensa formamos um desejo e aventuramos um pedido. Somente isto. 
Desejamos que quando um dia, distante ou próximo que nos chegue, fecharmos o ciclo desta nossa peregrinação, tracemos aqui a última linha com a mesma serenidade e consciência com que escrevemos as primeiras...» (O Amigo do Estudo, n. ${ }^{\circ} 1$, p. 1, col. 1).

\section{Conteúdo}

Como o próprio título sugere e os seus responsáveis o deixam entender, nas palavras que escreveram a servirem de «Introdução», este periódico procura divulgar saber, em múltiplas e variadas dimensões, contribuindo assim para um certo enriquecimento e ilustração cultural dos seus leitores.

Compõe-se esta colecção de dez números, todos, sensivelmente, com a mesma estrutura interna, o mesmo formato e número de páginas, excepto o n. 9 que, em vez das oito páginas habituais, apresenta doze.

Interpretando o espírito do tempo, procura-se divulgar o máximo de conhecimentos. Daí a imensa variedade de assuntos tratados. Sintetizando-os, diremos que um dos mais em foco diz respeito ao mundo das letras. Para além de alguma produção literária, onde se evidencia o poema dramático «Onofre» de João Penha, são de salientar, no âmbito da literatura, o artigo «Ensaios de crítica literária», repartido por três números, de F. Guimarães Fonseca, relativo à vida $\mathrm{e}$ obra de Octave Feuillet; de F. Adolfo Coelho, que, em «Curiosidades da História Literária», reflecte, citando exemplos, sobre a influência francesa em Portugal e vice-versa, para, em "Jorge de Montemor e os romances pastoris», nos dar conhecimento dos seus romances, nomeadamente, de Diana Enamorada, enquanto J. Frederico Laranjo, em «Virgilio», nos fala de Horácio e do autor da Eneida e a influência deste último em Portugal e na civilização moderna.

Uma referência muito especial para a literatura de viagens e para o pitoresco paisagístico. Aqui, é A. A. da Fonseca Pinto quem, em «Apontamentos de Viagem», nos descreve zonas do país, que vão de Condeixa a locais vários da cidade de Lisboa, passando por Leiria, Alcobaça, Alenquer e Carregado. Também J. U. de S., em «Apontamentos de uma viagem a Sintra», nos descreve as belíssimas paisagens desta região, nos fala das suas águas, do seu palácio e outros centros de interesse. É ainda J. Frederico Laranjo quem nos faz a descrição 
de uma grande propriedade rústica, em «Descrição do prado. Granja em Castelo de Vide».

Ainda no domínio das letras, Costa Alemão, em «A língua portuguesa», falanos um pouco da história da nossa língua, do contributo que vários reis lhe prestaram, dos galicismos, para concluir que se pode estudar «o francês, mas não se despreze o português, e sobretudo não se afrancese» (n. ${ }^{\circ} 10$, p. 81, col. 2).

Em sintonia com os tempos, as temáticas científicas, de que salientamos os artigos seguintes: "As tartarugas marinhas» e "Chuva de Sangue», ambos da autoria de A. Filipe Simões, que nos esclarece sobre aqueles animais, mares onde habitam, sua pesca e utilidades e nos explica o fenómeno meteorológico de, por vezes, caírem chuvas avermelhadas; V. de Meireles, no artigo «Geografia médica", elucida-nos sobre fenómenos geológicos e climatológicos, em várias zonas do globo, e das condições biológicas dos povos que aí habitam; M. da Costa Alemão, em «Isolamento da Terra», procura demonstrar o isolamento e suspensão do nosso planeta.

$\mathrm{Na}$ área da ciência histórica são de referenciar os seguintes artigos e notícias: «Descobrimento da América pelos Normandos», de Francisco Adolfo Coelho que nos dá um conjunto de informações relativas a este povo do norte da Europa, para concluir que, embora o nome de Cristovão Colombo esteja presente na mente de todos, "para o historiador imparcial a glória do descobrimento caberá aos escandinavos» (n. ${ }^{\circ}$ 9, p. 69, col. 2); A. M. Seabra de Albuquerque referencia-nos os bastardos da coroa real portuguesa, em «Os Bastardos» e, em «Do estudo heráldico em Portugal», fala-nos sobre o contributo recebido de França nesta matéria, as primeiras armas em Portugal e a situação da heráldica entre nós, para, novamente, A. Filipe Simões nos dar conta dos «Efeitos do grande terramoto do $1 .^{\circ}$ de Novembro de 1755 na cidade de Coimbra, segundo uma relação impressa daquele tempo».

Finalmente, ainda no domínio da história, sobretudo da história da Universidade, a notícia do doutoramento de Joaquim José Maria de Oliveira Vale e as orações que, na altura, foram proferidas pelos Professores José Augusto Sanches da Gama e Luís Leite Pereira Jardim, as quais aqui se publicam, «não já pelo seu merecimento, como pela particularidade de serem os primeiros discursos académicos que em tais actos se proferiram na língua nacional» (n. ${ }^{\circ}$ 9, p. 65, col. 1). 
Um lugar ainda para as questões de educação e instrução, em artigos como "Instrução e Educação do Povo», «Educação Física» e "Ginástica», todos da autoria de Rocha Viana. No primeiro advoga-se uma instrução para todas as classes; fornecem-se, também, dados estatísticos relativos à instrução primária, no nosso país, segundo a inspecção de 1863-1864. Nos outros faz-se uma defesa da educação física. Citando o exemplo dos gregos, reconhece-se que «é sobretudo necessário que em as nossas casas de educação se instituam aulas próprias, nas quais professores competentes se ocupem de desenvolver e avigorar a nossa degenerada mocidade, pela aplicação dos variadissímos preceitos duma arte tão nobre como útil» (n. ${ }^{\circ}$ 9, p. 72, col. 2).

Ainda ao nível da educação, J. C. Preto Pacheco, no artigo «A associação e suas vantagens», faz, não só uma crítica ao socialismo e ao comunismo, como também refere as vantagens imensas do associativismo, dizendo mesmo que «a associação é irmã gêmea da democracia» (n. ${ }^{\circ}$ 2, p. 9, col. 2) e é dela que «há-de brotar a futura regeneração social» (Idem, p. 10, col. 1).

Em alguns números, aparece-nos a secção «Bibliografia», onde se fazem apreciações de obras dadas à estampa. 


\section{9 - O AMIGO DA ORDEM}

Coimbra, Real Imprensa da Universidade 1821

Responsáveis: Não indica

Colaboradores: Não indica

Formato: 14 x $20,5 \mathrm{~cm}$

Periodicidade: Não indica

Preço: 80 réis

Páginas: 32
Cotas:

BN: J.976//2P.;P.P.10490V

BGUC: Misc. 138; 9-(3)-14-35

BPMP: RES-XIX-A-30(2)

BMC: GHC-3

\section{Objectivo}

"Tendo nós chegado finalmente a esta felicidade de tempos, em que é permitido a qualquer o dizer a verdade, e tendo-se publicado, e continuando a publicar-se tantos estimáveis periódicos, que tanto concorrem para o estabelecimento do sistema constitucional, donde absolutamente depende o bem da Nação; eu me animo também a publicar este só com o fim de comunicar aos meus compatriotas algumas ideias políticas e morais, e de concorrer por este modo para a manutenção da presente ordem de coisas, em que todo o homem de bem, e de algumas luzes se deve interessar. Praza a Deus, que os meus escritos se conformem com as opiniões dos homens sensatos e virtuosos, e que também possam servir de modelo à mocidade portuguesa, para que no seu ardimento de escrever nunca transgrida os limites, que a este respeito prescreve a razão, a justiça e a boa ordem!...

Escrevamos sim, mas escreva-se só com o fim de instruir o povo, e de o conter nos verdadeiros limites, que exige o bem da sociedade... Para se manter e consolidar a presente ordem de coisas nada contribuirá tanto, como a instrução do povo, para que ele saiba conhecer a diferença que há entre a religião e a superstição, entre a piedade e o fanatismo, entre a virtude e a hipocrisia...

A instrução e a civilização dos povos, que sempre andam acompanhadas uma da outra são de tal modo opostas ao despotismo, que existindo elas, perde este toda a sua força, ainda quando se conserve debaixo do mesmo nome. Nunca um tirano pode governar só uma nação inteira; ele depende dos ministros e conselheiros, e estes da opinião pública» (O Amigo da Ordem, n. ${ }^{\circ}$ 1, pp. 1-3). 
«Por inadvertência não disse no primeiro número deste periódico, que plano me tinha proposto para a sua composição. $\mathrm{O}$ meu objecto principal pois é publicar por este modo alguns discursos morais traduzidos e escolhidos dos periódicos moralistas ingleses, como o Vagabundo , o Preguiçoso, etc. Discursos, que naquela Nação, certamente uma das mais polidas e civilizadas da Europa, merecerão geral aplauso. A estes acrescentarei também alguns da minha própria composição, e acomodados às nossas políticas circunstâncias, e isto com o fim de concorrer para a vulgarização das ideias liberais...

Sendo pois tal o meu plano, destituído inteiramente de notícias, de que o público presentemente e com razão é tão ávido, e achando-se além disso fechada a Universidade, eu não me admirarei de que discursos de mera instrução ou recreio achem poucos compradores» (Idem, n. ${ }^{\circ}$ 2, p. 31).

\section{Conteúdo}

Apesar de em O Amigo da Ordem não haver qualquer indicação quanto ao seu autor ou autores, segundo Carneiro da Silva trata-se de um «periódico de estudantes» (Ob. cit., p. 12). Daí a razão da sua inclusão neste repertório. Também não sabemos quais os meses ou dias em que foi dado à estampa. Os dois números publicados referem, apenas, o ano de 1821.

De acordo com o objectivo e plano traçados, este pequeno periódico procura uma divulgação das ideias liberais. Apelidando as Cortes de «Augusto Congresso» (p. 2) e fazendo uso de exemplos da história, nomeadamente dos tempos feudais, faz-se a apologia do regime constitucional, da liberdade e dos direitos do cidadão, ao mesmo tempo que se critica todo o tipo de opressão e violência, se denunciam os detractores de 1820 e da Constituição e se aconselham os cidadãos a não dar «ouvidos às suas malévolas sugestões» (p. 22). Acredita-se mesmo que «adoptado por todos o sistema constitucional de Governo, virá um tempo em que os Príncipes se liguem sinceramente para afastar de todo e para sempre de suas vizinhanças a sede do Despotismo, da escravidão e do fanatismo» (p. 10).

Recusando afirmar-se como um jornal noticioso, procura antes apostar na formação de cidadãos conscientes. Daí a importância de artigos de carácter moralizante, alguns traduzidos até da imprensa inglesa como, por exemplo, «Estreiteza da Fama» (pp. 11-16) e «Dificuldade de se adquirir nome» (pp. 25-30).

Reconhece-se, igualmente, que a imprensa e a educação dos povos têm em todo este processo um papel importante e fundamental. 


\section{0 - O AMIGO DO POVO}

Coimbra, Tipografia Nova

3 Maio 1823 - 24 Maio 1823

\section{Objectivo}

«...O amor da pátria é quem nos dirige, porque temos por divisa: Constituição ou Morte. Se alguma coisa falta aos redactores do Amigo do Povo não é sem dúvida incorruptibilidade, honra, patriotismo e imparcialidade. Eles não conhecem outro partido, mais que o partido da liberdade e da razão. Felizes se nunca se desviarem desta entrada; e olhando para a sua vida pública possam dizer sem mentira: amámos sempre e sinceramente a nossa pátria». (O Amigo do Povo, n. ${ }^{\circ}$ 1, 3 de Maio de 1823, p. 9).

“O Amigo do Povo está inteiramente decidido a atacar os abusos e despotismos debaixo de qualquer forma que eles apareçam; mas personalizar e ofender nem é o seu carácter nem a causa pública o exige. Há porém abusos tão essencialmente ligados com as pessoas que se não podem atacar os primeiros sem se atacar os segundos. É só por este motivo e por dar uma prova de que ele não olha indiferentemente pela causa dos desgraçados, de quem apesar de todos os perigos se mostrará o constante defensor, que ele publica esta carta...» (Idem, suplemento ao n. ${ }^{\circ}$ 4, 26 de Maio de 1823, p. 5).

\section{Conteúdo}

Este pequeno jornal, organizado pelos irmãos Passos, afirma-se como um espaço de defesa em prol do constitucionalismo, da liberdade e da igualdade entre os cidadãos, nomeadamente dos mais desfavorecidos. $\mathrm{O}$ discurso utiliza- 
do é, por vezes, pouco simpático, sobretudo quando se refere às classes privilegiadas: «aqueles que comem sem trabalhar, aqueles que comem mais do que devem são os que têm obrigação de pagar as despesas da guerra» (n. ${ }^{\circ}$ 2, pp. 2021).

A estrutura interna de $O$ Amigo do Povo é a mesma nos quatro números que compõem a colecção. De salientar ainda a existência de um suplemento ao n. ${ }^{\circ}$.

Nos artigos de $O$ Amigo do Povo perpassam dois grandes temas: o mais importante é, sem dúvida, de natureza política e diz respeito ao regime constitucional e às Cortes: reflexões sobre liberdade e constituição; a defesa intransigente da liberdade conquistada (a organização das guardas cívicas); a defesa inflexível da constituição; as Cortes (o alcance de algumas das medidas tomadas; imagens de deputados: Agostinho José Freire, Alexandre Alberto Serpa Pinto, António Gomes Henrique Gaio, António José da Silva Peixoto, António Júlio de Frias Pimentel, António Lobo Barbosa Ferreira Girão, António Marciano de Azevedo, António Pinto Coelho Soares de Moura, António Pretextato de Pina e Melo e António Vicente Carvalho e Sousa; o segundo inscreve-se no âmbito da Justiça: Justiça Social - a defesa dos mais fracos e desprotegidos e as críticas às classes privilegiadas, sobretudo aos bispos e ao clero -, que «arrebatam somas imensas do erário nacional» (n. ${ }^{\circ}$ 1, p. 15); a importância da institucionalização dos jurados, porque «a lei dos jurados é talvez a única lei que pode nivelar o cidadão desvalido ao mais prepotente despota» (n. ${ }^{\circ} 1$, p. 9).

Para além de um elogio à obra poética do estudante José Frederico Pereira Marrecos, completa-se este periódico com notícias do país e do estrangeiro e alguns anúncios.

Bibliografia: Luís Reis Torgal, «A imprensa estudantil em Coimbra e o radicalismo liberal vintista», O Liberalismo na Península Ibérica na primeira metade do século XIX (Coordenação de Miriam Halpern Pereira, Maria de Fátima Sá e Melo Ferreira e João B. Serra), 2. ${ }^{\circ}$ Volume, Lisboa, Sá da Costa Editora, 1982, pp. 241-56; Luís Reis Torgal e Isabel Nobre Vargues, A revolução de 1820 e a instrução pública, Porto, Paisagem Editora, 1984, pp. 275 e ss. 


\section{1 • ANÁTEMA}

Coimbra, Imprensa Independência

Maio 1890

Editores: António Vaz de Macedo e Artur Pinto da Rocha

Colaboradores: Artísticos: Rafael Bordalo Pinheiro, Nicola Bigaglia e L. Battistini; Literários: Antero de Quental, Henrique de Barros Gomes, Visconde de Seabra, João Penha, Luís de Magalhães, Jaime de Magalhães Lima, Gomes Leal, Oliveira Martins, Bernardino António Gomes, Amália Vaz de Carvalho, Rodrigues de Freitas, Bernardino Machado, Basílio Teles, Bulhão Pato, Henrique Lopes de Mendonça, Teófilo Braga, Fialho de Almeida, Serra Mirabeau, Tomás Ribeiro, Eça de Queirós, Guerra Junqueiro, Cesare Lombroso, Jean Richepin, Emília Pardo Bazán, Enrico Ferri, F. Pi y Margall, Joseph Reinach, F. Giner, P. G. Molmenti, Eugéne Guyon, Giovanni Bovio

Formato: $27 \times 38,5 \mathrm{~cm}$

Periodicidade: $N .^{\circ}$ único

Preço: Não indica ${ }^{(1)}$

Páginas: 47
Cotas:

BN: J.1662//3V.; J.3106V.

BGUC: -

BPMP: COR. 2424

BMC: GHC-21/1

\section{Objectivo}

«Foi a sinceridade do nosso protesto contra essa potência mercantil e egoísta, que nos determinou a realizar esta publicação. Eis o resultado da nossa tentativa. Dirigimo-nos aos homens mais eminentes de Portugal, Espanha, França, Itália e România, sem distinções de cores políticas... Ainda assim, o acolhimento que teve o nosso convite demonstra bem que ainda se não apagou no espírito dos povos o ideal de justiça e do direito. E essa convicção animou-nos a prosseguir nos nossos intuitos de protesto contra este acto de vandalismo praticado no mesmo fim do século em que se glorifica em Paris a mais sublime conquista social de que nos fala a história.

(1) Todavia, o produto líquido revertia em favor da grande subscrição nacional. 
Dedicando-o à Academia portuguesa... rendemos um preito de justiça à corporação que acordou na alma portuguesa, a consciência da sua vida nacional». (Anátema, p. 46).

\section{Conteúdo}

Colaborado por personalidades várias e ilustres de Portugal e do estrangeiro, este jornal insere-se no grande movimento de protesto que se seguiu ao Ultimatum decretado pela Inglaterra, em Janeiro de 1890.

Independentemente da tónica e do estilo literário adoptados pelos colaboradores, este periódico pretende, fundamentalmente, não só denunciar o mal-estar sentido em relação à Grã-Bretanha, a quem chamam "potência mercantil e egoísta», mas também a estreiteza das nossas instituições políticas e actuação do governo português. A este propósito, escreveu, então, Antero de Quental o seguinte: «Há no grande movimento nacional, que começou no dia 11 de Janeiro, um elemento afirmativo, que é a intensa paixão patriótica do povo português, e um elemento negativo, o descrédito das nossas instituições políticas, das práticas de governo e dos homens governantes» (Idem, p. 9 col. 1).

Diga-se, também, que a par de um discurso de protesto e de crítica, existe, igualmente, um discurso de esperança e certeza que A. Pereira da Cunha, entre outros, sintetizou assim: «Ontem dizia-se: isto está perdido; hoje pode-se dizer: isto há-de-se salvar» (Idem, p. 12, col. 1). 


\title{
12・ARGUS
}

\author{
Ideal e Verdade Cotas: \\ Coimbra, Minerva Central \\ 15 Dezembro 1896 - 28 Fevereiro 1897 \\ BN: J. 5690//4B.;P.P. 11140 V. \\ BGUC: - \\ BPMP: - \\ BMC: GHC-2-S
}

Directores: Literário - Alexandre de Albuquerque; Científico - Ferreira Lemos

Secretário: J. Marques

Redactores: António Macieira, Barbosa de Magalhães (Filho), Mário Esteves, Patrício Judice e Simões Baião

Colaboradores: Verediano Gonçalves, Guedes Teixeira, Afonso Lopes Vieira, Alexandre Braga, João Grave, Gomes Leal, Henrique de Vasconcelos, Júlio Brandão, Teófilo Braga, Adolfo Portela, Gonçalves Cerejeira, Maximiano de Aragão, Alberto Pinheiro, Carlos de Lemos e outros

Formato: 14 x 20,5 cm

Periodicidade: Bimensal

Preço: Trimestre -200 réis

Páginas: $1 .^{\circ}$ Vol. - I Série - 150

2. ${ }^{\circ}$ Vol. - II Série - 161

\section{Objectivo}

"Moços e destemidos partimos num alegre bando - uns à cata do Ideal, outros da Verdade. Fomos andando, andando, mas não tocamos a estrelinha dos Reis Magos - o Ideal estava muito alto, a Verdade muito longe.

Que nos valeu avistar o jardim florido de sonhos e quimeras onde se encontra o Ideal, se dragões o guardavam!...

E desde o princípio da jornada que um dragão nos perseguiu - a própria aspiração, a ânsia de subir. Ambicioso por natureza, o homem quanto mais tem, mais quer. O Ideal de hoje não é o Ideal de ontem, como não será o Ideal de amanhã. O Ideal atingido é a realidade e a realidade não basta ao espírito humano. O homem, mal toca o que ele julgou o Ideal, conhece que se iludiu, e deserta, doido e aventureiro, com os olhos fitos noutra estrela.

À proporção que o homem sobe, sobe também o seu Ideal. Querer agarrá-lo é o mesmo que exigir às rodas posteriores de um carro que alcancem as 
dianteiras. Por maior que seja a velocidade, a distância conserva-se sempre a mesma. Assim o Ideal. O homem tenta aproximar-se? Ele afasta-se. O homem avança um passo? Ele recua um passo... Felizes aqueles cujo Ideal é ter aquilo que têm, ser aquilo que são!

E quanto à Verdade está muito próxima da Mentira. Confundem-se muitas vezes, porque a Mentira para melhor enganar toma aspectos de Verdade. Faz-nos lembrar o Anjo-Mau que se disfarça em Anjo-Bom para tentar os crentes do Senhor.

Se não atingirmos o Ideal e não tocamos a Verdade, nem por isso desanimámos...» (Argus, Série II, Ano I, n. ${ }^{\circ}$ VI, Coimbra, Abril de 1897, pp. 145-46) ${ }^{(1)}$.

\section{Conteúdo}

Desta revista publicaram-se duas séries. Num total de seis números, cada, a

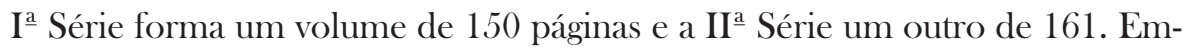
bora o formato seja o mesmo nas duas séries, já o número de páginas varia de número para número, mesmo dentro da mesma série. Números há, até, que

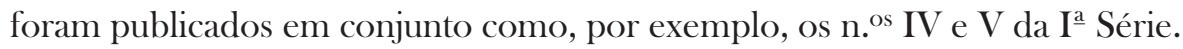
De salientar, também, um erro de tipografia, na paginação inicial da II $^{\underline{a}}$ Série.

Os números saídos não têm as datas da sua publicação. No entanto, os números da I ${ }^{\underline{a}}$ Série, no exemplar por nós consultado, na B.M.C., ostentam datas manuscritas, as quais foram apuradas pelo General Martins de Carvalho, segundo informação de Carneiro da Silva (Ob. cit., p. 14).

Argus é, essencialmente, uma revista de carácter literário. Com o subtítulo de «Ideal e Verdade», procura afirmar-se não só como um espaço de criação, seja em prosa ou em verso, mas também de estudo, de crítica e de reflexão.

Aqui se dão a conhecer textos inéditos, excertos de livros em preparação, partes de obras cuja saída do prelo está iminente e de que são exemplos, entre outros, os assinados por Verediano Gonçalves, Henrique de Vasconcelos,

(1) Ao contrário da grande maioria das publicações que, logo no primeiro número, fazem a sua apresentação e definem os seus objectivos, com Argus assim não acontece. $\mathrm{O}$ texto que acabamos de transcrever encontra-se publicado já nas últimas páginas da II $^{\underline{a}}$ Série e corresponde à despedida. Elaborado pela redacção, o texto intitula-se mesmo «Adeus». Foi aqui colocado, na medida em que expressa o pensamento de uma vivência. 
Adolfo Portela, João Grave, Alberto Pinheiro, Vilela Passos e alguns de Alexandre de Albuquerque e Simões Baião. Reflectindo as vivências do tempo, nestes textos, em prosa e verso, são evidentes, quer ao nível da expressão, quer dos conteúdos (até nos próprios títulos), os traços genéricos de uma literatura de fim-de-século.

Para além de criação literária, existe um conjunto de textos, artigos e reflexões, cuja temática se situa, não só ao nível do estudo literário (ex.: «Evolução Literária» e «O Lirismo em Portugal»), mas vão muito mais além, pois têm a ver com o vasto problema que é a questão social, a que não é alheio, nesta altura, e entre outros factores, o trânsito de uma sociedade semifeudal para um modo de produção capitalista. Patrício Judice, por exemplo, no seu artigo «Questões Sociais», reconhece que a sociedade se caracteriza por uma »desorientação das consciências» e, em termos de moral, por um «estado deveras caótico» (p. 34), enquanto Alexandre de Albuquerque, no estudo que faz sobre «Fausto Guedes Teixeira. O Homem e a obra», nos transmite a ideia de um certo insurgimento contra o quotidiano, o normal e o comum da vida, retrato este que o seu biografado expressou assim: «miserável mundo que só tem cuidados» (p. 57).

De uma maneira geral, todos os escritos referentes a esta questão reflectem uma certa dor de consciência de seus autores, que se traduz no sentimento de exploração de que a humanidade está a ser vítima. Se, no texto intitulado «Os Mineiros», Alexandre de Albuquerque reconhece, não só o sofrimento desta classe, que vive «nas profundas da terra, paredes-meias, com o inferno» (p. 9), mas também a injustiça dos seus salários, porque o proprietário fecha »os olhos cruelmente, piamente, à miséria daqueles que o enriqueciam» (p. 12), já, em "A Prostituição», Ferreira Lemos denuncia o espezinhamento da mulher e o limite das relações humanas que o dinheiro impõe.

Estudos de crítica, também, na apreciação que Barbosa de Magalhães faz à dissertação «A Dor Humana» de Samuel Maia e Ferreira Lemos à obra «Socialismo Libertário ou Anarquismo» da autoria de Silva Mendes.

De salientar um leque de assuntos sobre a Grécia Antiga: pintura, religião, mitologia, filosofia e a mulher grega.

Numa rubrica de política internacional, Barbosa de Magalhães fala-nos, entre outros assuntos, de Creta e da guerra em Cuba. 
Finalmente, numa secção de «Bibliografia», dão-se notícias várias, nomeadamente dos trabalhos recebidos, anunciam-se novos colaboradores, fazem-se agradecimentos, tecem-se pequenos comentários a livros e publicitam-se alguns que acabam de ser dados à estampa. 


\section{3・ O ASTRO}

Jornal literário, semanal e noticioso.

Orgão da classe Académica

Coimbra, Imprensa da Ordem (1)

2 Dezembro 1883
Cotas:

BN: J.5691//1B.

BGUC: -

BPMP: -

BMC: GHC-19/3

Colaboradores: Júlio Serrano, Maria José F. de

Mendonça, Lucinda Cândida de Andrade

Formato: $15,5 \times 23,5 \mathrm{~cm}$

Periodicidade: Número único

Preço: Assinatura - Mês - 150 réis

Trimestre -450 réis

Páginas: 4

\section{Objectivo}

«A imprensa, sendo a expressão mais espontânea do pensamento humano, é também um dos processos que com maior vantagem robustece os espíritos, cuja educação intelectual principia.

Foi pela observação deste pensamento quase axiomático, que nos sugeriu a ideia da criação dum novo orgão da imprensa literária e é por isso que agora afastamos o reposteiro da actualidade e entramos no vastíssimo salão do jornalismo.

Devemos advertir primeiro que tudo que o Astro não tem fixado para os escritos que inserir, escola alguma; pelo contrário aceita-os de qualquer género, com tanto que eles por si dêem vulto e relevo ao novo jornal.

Podemos, contudo, afirmar que o estilo lírico dará um contingente apreciável para o brilho do Astro, atendendo à colaboração de damas distintas que, cultivadoras deste género de literatura poética, nos têm mimoseado com as suas produções. Esta escolhida colaboração feminina será um atrativo a mais para a nossa folha...» (O Astro, n. ${ }^{\circ}$ 1, Coimbra, 2 de Dezembro de 1883, p. 1).

(1) Em manuscrito, lê-se: «Na Imprensa da Ordem». 


\section{Conteúdo}

Trata-se de um pequeno jornal literário e noticioso, do qual se publicou apenas o primeiro número. No campo das letras, a preferência vai para a poesia lírica, onde se salientam os nomes femininos de Maria José Mendonça e Lucinda Cândida de Andrade.

Porque jornal estudantil, é Júlio Serrano quem, num pequeno texto intitulado «Duas Lérias», se mostra pouco simpático com a praxe, nomeadamente as trupes, e nos conta como ele foi vítima destas práticas. Referindo-se-lhes, diz-nos: «alí andam as trupes, furiosas, famintas de cabelos, empunhando a terrível tesoura diamantina, verdadeiro flagelo de caloiros e novatos» (Idem, p. 3, col. 1).

Completa-se este jornal com pequenas notícias da vida escolar e académica (ex.: uma alusão às eleições no Clube Académico). 


\section{4 - O ASTRO DA JUVENTUDE (1)}

Folha Recreativa

Coimbra, Imprensa Literária

23 Janeiro 1879 - 7 Fevereiro $1879^{(2)}$
Cotas:

BN: J.3146//10B; J.1408B

BGUC: -

BPMP: -

BMC: GHC-20/10

Director: A ADELD (Abílio Albano de Lima Duque)

Colaboradores: Alfredo Tomás de Brito, Eduardo

Martinez, A. A. de Noronha, S. Araújo Junior, Júlio

de Magalhães

Formato: $22,5 \times 31 \mathrm{~cm}$

Periodicidade: Quinzenal

Preço: 100 réis mensais

Páginas: 4

\section{Objectivo}

«O Astro da Juventude, cujos prospectos se espalharam sob o nome de Caloiro, é uma folha quinzenal, que tem por fim directo - o doce recreio da alma.

Não, não são páginas dedicadas a estudantes, como o Caloiro dizia; mas a todas as classes que abraçam fervorosas o progresso e a ciência.

O Astro da Juventude será noticioso e só não admite no seu recinto humilde artigos de política, que a espíritos juvenis pouco ou nada interessam. Apenas publicará, dos frutos preciosos da árvore literária, aqueles que condigam com seu pensar modesto: e, seguindo as duas escolas - lírica e realista, recusa a inserção de escritos artísticos. É este o seu programa" (O Astro da Juventude, n. ${ }^{\circ}$ 1, Coimbra, 23 de Janeiro de 1879 , p. 1).

(1) Na secção «Noticiário" lê-se: «Tencionava a redacção dar a esta folha o nome de Caloiro, mas motivos imprevistos não permitem que o Astro da Juventude use de nome tal» (N. ${ }^{\circ}$ 1, p. 4, col. 2). Na B.M.C., junto com este periódico encontra-se o prospecto de $O$ Caloiro.

(2) No n. ${ }^{\circ}$ 2, há um erro de impressão na data. Em vez de Fevereiro estava escrito Janeiro. A corrigenda está manuscrita. 


\section{Conteúdo}

Trata-se de um pequeno e modesto periódico que não foi além do segundo número. Como nos refere o seu director, este pequeno jornal é dirigido não só a estudantes, mas a todas as classes e visa contribuir para «o doce recreio da alma».

Apesar de a colecção deste periódico contar apenas com dois números, eles não são iguais na sua estrutura. Assim o diz o seu director, ao escrever: «Saiu o 1. ${ }^{o}$ número do Astro da Juventude dividido em duas partes - Variedades e Noticiário; porém, este número (o 2. ${ }^{\circ}$ ) e os seguintes sofrem alteração, sendo composto o jornal de três secções: filosófica, literária e noticiosa» (n. 2, p. 4, col. 1).

Para além de textos literários, em prosa e verso, e de notícias de pouca monta, o que de mais importante há a assinalar é, na secção literária, algumas reflexões sobre a «idade encantadora» (n. ${ }^{\circ}$ 2, p. 3, col. 1) da juventude; na secção de filosofia, um artigo sobre a mulher, intitulado mesmo "A mulher». Depois de uma breve referência à criação do homem e da mulher, suas individualidades e recíprocas dependências, o seu autor não deixa de se questionar, dizendo: «Quanto é absurda, pois a pretensão do homem! Querer para si a liberdade, para a mulher a escravidão; para ele os gozos, para ela as dores; para ele o direito, para ela o dever; para ele a autoridade, para ela a obediência; para ele a luz científica, para ela a ignorância...», para, depois, concluir, afirmando que a mulher é «o ser mais belo de todos quantos vivem nesta mansão terrestre» (n. ${ }^{\circ}$ 2, p. 2, cols. 1 e 2).

De salientar a existência de um folhetim. 


\section{5 - O ATENEU}

Periódico mensal, científico e literário

Coimbra, Imprensa da Universidade

31 Outubro 1859 - 28 Fevereiro 1860
Cotas:

BN: J. 397 B.

BGUC: $10-7-14-8$

BPMP: P-B-2605(1)

BMC: GHC - 1

Redactores: Camilo Castelo Branco, José Cardoso

Vieira de Castro e António Vitorino da Mota

Colaboradores: João de Deus, J. Pinto Ribeiro Júnior,

Agostinho da Rocha, Alfredo Tomás de Brito e A.

A. de Noronha

Formato: 19 x $28 \mathrm{~cm}$

Periodicidade: Mensal

Preço: Assinatura - $1 \$ 800 \bullet$ Avulso - 300 réis

Páginas: 168

\section{Objectivo}

«Os aventureiros de publicações literárias em Coimbra cometem um ardimento, pelo menos tão digno de acarear benevolência como o lidado afogo do botânico em levedar por estiradas sestas de calmoso esto, revendo suores, terrenos asmos, que ele antecipadamente destina às condimentosas sementes de mais peritos amadores...

Do que fica dito contrai-se o alcance da ardideza, a que hoje nos abalançamos. O Ateneu arca, não obstantes os empeços desta ominosa e mal-agourada experiência, com os relutantes fados que lhe é dado pressentir, rompe jornada, e procura desassombrar-se no caminho.

Declara-se, finalmente, que esta trilogia periodista é avessa e refractária aos programas.

O programa, maxime quando vem incampado à credulidade pública nos refalsados ardis de uma frase opilada de promessas farfalhudas, é sempre uma excrescência adiposa e algumas criaturas homericamente ineptas, a qual seria humana e nimiamente bom que fosse morrendo assim como morreram, ao mando de julgadores avisados, os prólogos, os sonetos, os epitalâmios, os acrósticos, os ditirambos e os epitáfios em verso; assim como morreriam também os necrológios, se esta reabilitação póstuma não fosse tão urgente como a barrela para as últimas limpezas de muito patife que, sem isto, teria de apare- 
cer-nos atrozmente hediondo, quando o ósculo gélido da morte lhe viesse desanuviar de sobre a face hipócrita esses assomos de rigidez ascética, com que eles a revestem, quando por acaso deparam connosco nos meandros da sociedade em que vivem.

Resta definir a palavra que vem no topo destas páginas e que, sem isso, poderia pôr em sobressaltos a inteligência massuda de alguns intérpretes pechosos.

Ateneu quer dizer academia.

Academia o lugar onde se reunem académicos. Está feito o convite e a apresentação. Disse» (n. ${ }^{\circ}$, pp. 1-9).

\section{Conteúdo}

Dizendo-se refractário a programas, $O$ Ateneu afirma-se, essencialmente, como um periódico literário, mas onde as questões educativas ocupam, também, um lugar especial.

A colecção completa desta publicação é de cinco números, todos com o mesmo número de páginas -32 , excepto o n. ${ }^{\circ}$ 3, que apresenta 40, formando-se, assim, um pequeno volume com 168 páginas. Todos os exemplares apresentam o mesmo formato e a estrutura interna.

Como periódico do mundo das letras e aberto a todos os académicos, nele se vertem criações literárias, em prosa e em verso, como, por exemplo, os romances «O Filósofo de Trapeira», de Camilo Castelo Branco e «Alcina», de José Cardoso Vieira de Castro e ainda «Uma história», de Vitorino da Mota, a par de poesias várias.

No domínio da literatura, é o mesmo Vitorino da Mota quem, em «Ideias ao Acaso", reflecte sobre questões do romance, para Vieira de Castro, no artigo intitulado «Um curto proémio», tecer considerações sobre poesia, citando, nomeadamente, Bernardim Ribeiro, a quem chama «o coronel de uma escola» (N. ${ }^{1}$, p. 21) e nos fala de João de Deus e sua poesia.

Quanto a questões relacionadas com educação é Camilo Castelo Branco quem, citando Vicq d'Azir, nos fala de António Nunes Ribeiro Sanches e da forma como se deviam restabelecer as escolas e restaurar os bons estudos. Ainda neste âmbito, publica-se «História e causa de decadência dos bons estudos», 
um inédito do nosso estrangeirado, onde este nos dá uma visão global das primeiras escolas cristãs e do que nelas se ensinava, para, por fim, reflectir sobre as escolas eclesiásticas.

De salientar ainda, neste domínio, o discurso proferido na Sala dos Capelos, em 8 de Dezembro de 1859, pelo Professor Alberto de Sousa Pinto, onde, entre outras directivas, exorta os estudantes ao culto do espírito, com o estudo e com o trabalho, devendo, para tal, aproveitar «o tempo e os sacerdotes, que a Universidade vos oferece para esse culto» (n. ${ }^{\circ} 3$, p. 66).

A completar este periódico e da responsabilidade de Vitorino da Mota, a existência da secção permanente "Crónica», onde se procuram narrar episódios vários e, por vezes, grotescos que vão decorrendo em Coimbra. Aqui se fala, por exemplo, das mulheres de Coimbra, da Universidade, da Faculdade de Filosofia, de jornais e revistas, se criticam folhetins e teatro, etc. 


\section{6 • O ÁTILA}

Coimbra, Imprensa Literária

5 Dezembro 1863 - 26 Março 1864

Redactor: Rodrigo Veloso

Colaboradores:Rodrigo de Menezes, Teixeira Coelho, Junqueira Freire, Aleixo dos Santos, João de Deus, Teófilo Braga, Braga Macahé, Álvares de Azevedo, Eugénio de Barros e Antero de Quental

Formato: 16 x $23 \mathrm{~cm}$

Periodicidade: Semanal

Preço: Coimbra - 500 réis • Províncias - 560 réis

Páginas: 112

\section{Cotas:}

BN: J.118//9B.; J.313//22P J.2219P.

BGUC: 9-(3)-20-11

BPMP: P-B-2550

BMC: GHC - 2

\section{Objectivo}

«Leitor e amigo! Eu, o Atila, semanário cordato, sisudo, ordeiro e cabeleira te envio muito saudar, como aquele de quem tudo espero, e a quem, como tal, muito amo e reverenceio...

A época por que passamos é toda de dúvidas e provações... É uma ponte bambaleante que liga, separando-os, o passado de trevas com o futuro de luzes. É um imenso laboratório, onde se trabalham os gérmens de uma nova civilização, gérmens que amanhã fecundarão todas as ciências e sobre todas, a ciência do porvir - a política...

Os obreiros desta metamorfose estão na geração nova...

E que faz a Academia, a vanguarda obrigada do progresso no nosso país?

Confrange-se-me o coração por ver o corpo académico... desconjuntado, partido, esfacelado em mil individualidades caprichosas e atoadas, só propugnadoras do egoísmo e do eu intratável!...

Que quer dizer - o haver na Academia dois partidos? duas parcialidades políticas!...

Pois que! Vós que nunca vedes o facto, que nunca olhais ao homem que o pratica, mas só olhais à Ideia... vós que nunca vos importais com o campo prático e só viveis no especulativo!... haveis de consentir que no vosso seio se abram 
dois campos e dois campos políticos - dois partidos que por muito avançados que estejam, serão atrazadíssimos comparados com o partido do futuro de que sois os legítimos representantes!

A Ideia não se coaduna com tais pequenezas...

O Atila é a bandeira da paz. A sua missão é toda de conciliação. Seja o estandarte em volta do qual se alistem todos os obreiros do futuro e oráculos da Ideia. E com isto fecho, leitor, o meu cavaco» (O Átila, n. ${ }^{\circ} 1$, Coimbra, 5 de Dezembro de 1863, pp. 1-2).

«á dissemos, e não nos cansaremos de o repetir - a criação do Átila não teve em vista, senão o agrupar a Academia em torno de uma mesma bandeira - a fraternidade - fazendo quanto nela fosse para acabar com a desunião que naquela lavra. Alguns mal intencionados não quizeram reconhecer-lhe tal missão e têm-no apregoado por aí como orgão da sopa. Seja assim. Aceitamos a denominação, se é que ela quer dizer - anti-traça.

Traça e Sopa - são as duas parcialidades em que a Academia se diz coutada.

A primeira é sociedade organizada na noite - tem ritos maçonicos - juramentos terríveis - fim proveitoso, nenhum.

A segunda não tem organização alguma - ritos nenhuns - juramentos ainda menos - fim - a união da academia...

Assim posta a questão nos seus verdadeiros termos, o Átila é anti-traça, não o nega...

A vinda de SS.M.M. a Coimbra, a ovação calorosa e dedicada que lhes fez a Academia inteira, já desnudou parte das falsidades e aleives, que a traça lançava sobre a chamada sopa... O Átila repete-o de novo, é, e será anti-traça, enquanto a traça significar desunião na Academia» (Idem, n. ${ }^{\circ}$ 3, pp. 17-18).

\section{Conteúdo}

Reconhecendo existirem, no seio da Academia, desavenças motivadas em opções políticas, este periódico procura superá-las, centrando a sua aposta numa dimensão essencialmente literária e académica. Disso são exemplos, não só os vários textos literários, em prosa e verso, mas também o ensaio sobre poesia mística portuguesa, onde, depois de breves considerações gerais sobre a matéria, se fala do contributo dado por Frei Agostinho da Cruz e Frei António das Chagas. 
Na área da literatura clássica, de assinalar o artigo sobre Damião de Góis e a Crónica de D. Manuel onde, em nota de rodapé, se lê: «Iremos publicando no Átila algumas frases dos nossos clássicos, umas notáveis pela sua beleza, outras, cujo sentido aventuramos pois nem os Dicionários nem o Elucidário o apontam» (n. ${ }^{\circ} 6$, p. 47$)$.

Lugar também para as letras brasileiras com a apresentação de um dos primeiros poemas - Confederação dos Tamoyos -, por ser pouco conhecido e estar esgotada a edição. Divulgação, também, da poesia de Junqueira Freire, «o poeta do claustro e dos túmulos» (n. ${ }^{\circ}$ 2, p. 9, col. 2).

Espaço ainda para traduções como, por exemplo, «Da origem e formação das epopeias nacionais», de Émile de Laveleye.

Uma outra temática diz respeito à Academia. Com o título de «Cenas Académicas. Proezas dum caloiro", alude-se à vida de um estudante, em Coimbra, em múltiplas facetas. De anotar, aqui, referências à maçonaria.

No mesmo âmbito, o texto intitulado «Aos pais de família» e «Secção Económica», onde se fala do custo dos produtos em Coimbra, das despesas de um estudante e da mesada de que dispõe, para se concluir que «hoje nem o correr a lebre pode ali ter lugar» (n. ${ }^{\circ} 10$, p. 73, col. 2).

Completa-se esta publicação, cuja colecção engloba catorze números, todos com a mesma estrutura, com «Expediente» e a seç̧ão permanente de «Crónica». Se, naquele espaço, se tratam de questões do jornal, já em «Crónica» se dá conta de assuntos e notícias várias, sendo certo que é de teatro que, aqui, mais se fala, embora se reconheça que nem sempre é fácil fazer «Crónica de Coimbra noticiosa e sucolenta, pelos tempos que correm...» (n. ${ }^{\circ}$ 9, p. 72). 


\section{7 - AURORA DO MONDEGO}

Folha Semanal

Coimbra, Imprensa Literária

Outubro de 1879
Cotas:

BN: -

BGUC: -

BPMP: -

BMC: GHC-20/10-S

Directores: Hegel Huet e Herder Crates

Administrador: Gabriel Lotze

Formato: (1)

Periodicidade: Semanal

Preço: Trimestre -300 réis

Páginas: ${ }^{(1)}$

\section{Objectivo}

«Não são um reclame as palavras que se seguem...

Alheia à política militante no nosso país tratará nas suas colunas as questões de cuja solução depende o desenvolvimento intelectual do povo, porque só naquele vê o elemento, que concorrerá sem dúvida para erguer o operário ao campo aonde cumpra conscienciosamente os seus deveres e justamente exija lhe respeitem seus direitos. Filhos do povo, nas escolas aonde a propriedade de um punhado de ouro nos concedeu um banco, contraímos a obrigação de estudar também para aqueles, que não podendo vir beber a instrução à aula vivem acorrentados ao banco da oficina, e assim trabalhamos pelo progresso e obedecemos ao sentimento, que faz nascer a nossa folha» (Prospecto).

(1) Não passou do prospecto. 
18 - AZAGAIA

Coimbra, Tipografia Operária

Cotas:

Dezembro 1891 - Janeiro 1892

BN: -

BGUC: -

BPMP: -

BMC: GHC-2

Colaboradores: António José de Almeida, Cunha e Costa, Silvestre Falcão, Francisco Couceiro, Fernando de Sousa e João de Menezes

Formato: 12,5 x 16,5 cm

Periodicidade: Mensal

Preço: 50 réis

Páginas: 32

\section{Objectivo}

«Poderia supor-se que é nosso fim vir a público em defesa do grupo republicano académico a que pertencemos. Afigurar-se-ia isto natural a quem de longe tem seguido os acontecimentos provocados pela passagem da família real em Coimbra. Tem uma parte da opinião deste pacatíssimo burgo censurado e caluniado os republicanos académicos de maneira que natural pareceria que a Azagaia saísse a campo em defesa do grupo a que pertencem os seus autores.

Era este um dos caminhos que nos estavam abertos: contudo só acidentalmente tomaremos por ele. De ordinário seguiremos outro que julgamos mais directo e fecundo em resultados. E isto por uma simples razão: é que preferimos, sempre que isso é possível, apontar à opinião pública o caluniador, demonstrando-o como tal, a - por meio de processos dialécticos geralmente demorados e, quase sempre, ineficazes em parte - demonstrar a propositada 68 falsidade de uma afirmação.

Acresce ainda, e bastaria esta razão para justificar a nossa atitude aqui, que os nossos amigos só raríssimas vezes precisarão de que os defendam: enquanto que os nossos adversários desde muito que pediam o correctivo que nos propomos aplicar-lhes. É para os castigar, pois, que saímos a público: para lhes lançar em rosto a mesquinhez dos seus processos e a deslealdade da sua conduta apontando-os à opinião daqueles que no meio desse imundíssimo charco que se chama sociedade portuguesa têm a rara qualidade de conhecer que entre o bem e o mal alguma diferença existe... 
E, embora a opinião conspícua e ordeira do burgo coimbrão nos seja adversa, começaremos hoje a tarefa que a nós mesmos impusemos. Agora aos nossos adversários compete sair a campo e defender-se conforme as suas forças. Que venham: nós cá estamos. Eles têm a seu lado a lei das rolhas, a polícia, o governador civil e o Ferrão. É o partido que lhes damos.

Enquanto a nós, quando julgarmos conveniente apareceremos. Nos intervalos conservar-nos-emos sempre alerta, na frente dos nossos adversários, a Azagaia apontando-lhes à garganta. Assim, obrigá-los-emos a levantar a cabeça e a endireitar a espinha. É um serviço que lhes prestamos, creiam» (Azagaia, 1. ${ }^{\circ}$ Fascículo, Coimbra, Dezembro de 1891, pp. 3-6).

\section{Conteúdo}

Azagaia é um pequeno jornal de estudantes republicanos.

Como referem os seus redactores, este pequeno periódico surgiu como uma resposta e um meio de denúncia das actividades e dos comportamentos dos estudantes monárquicos, sobretudo no ano de 1891.

Nos artigos que compõem os dois fascículos deste jornal é possível identificar as seguintes questões:

- Estudantes monárquicos: como se definem, que métodos utilizam, quem os comanda;

- A revolta do 31 de Janeiro e as perseguições aos vencidos e a posição dos estudantes monárquicos;

- A viagem do rei à cidade do Porto: o protesto da Academia do Porto e o comportamento dos estudantes monárquicos e republicanos de Coimbra;

- A Academia de Coimbra: monárquicos e republicanos.

Completam este pequeno periódico alguma poesia e uma carta de Augusto Barreto, para responder, nas suas próprias palavras, a «uma calúnia torpe... forjada por algum sacripanta, que pretende macular-me o carácter» (n. ${ }^{\circ} 1$, p. 27). 


\section{A BARGAROLA}

Revista Literária e Recreativa ${ }^{(1)} \quad$ Cotas:

Coimbra, Tipografia Luís Cardoso BN: -

24 Fevereiro 1900 - 17 Junho 1900 BGUC: -

BPMP: -

BMC: GHC-4

Directores: Literários: Dá Mesquita Paul, João Aires de Azevedo e Gustaf Bergstrom;

Gerentes: César Monteiro e António Maria Beja da Silva ${ }^{(2)}$

Administrador: António Maria Beja da Silva

Colaboradores: Jerónimo de Paiva, José Barros Nobre, Costa Cabral, Luís de Sá Osório, Cacilda Garcez Pinto Coelho, Carlos Granja, Vieira Pinto, Jaime Diogo, Afonso Celso, Moreira Nunes, Damião Sireno, Etiel Rodrigues da Silva, Ribeiro de Carvalho e outros

Formato: 20,5 x 29,5 cm

Periodicidade: Semanal

Preço: Trimestre -340 réis $\bullet$ Avulso - 30 réis

Páginas: VIII

\section{Objectivo}

«Propozemo-nos a apresentar à vossa leitura esta revista, e fiados na benevolência de $V$. ${ }^{\text {as }}$ Ex. ${ }^{\text {as }}$ assim o fazemos.

É nosso intento tornar esta revista um orgão literário e recreativo; e, para que possamos prosseguir neste nosso desejo, esperamos dos nossos estimáveis leitores a sua valiosíssima cooperação, que de antecedência agradecemos» ( $A$ Barcarola, n. ${ }^{\circ}$ 1, Coimbra, 24 de Fevereiro de 1900, p. I).

\section{Conteúdo}

A Barcarola é uma pequena publicação que pretende ilustrar e divertir. Daí o seu carácter literário e recreativo.

(1) A partir do n. ${ }^{\circ} 13$ e com indicação de $2 .^{\text {a }}$ Série, o subtítulo passou a ser «Hebdomadário Literário e Recreativo».

(2) A partir do n. 13 passou a haver, também, directores-gerentes. 
Ao longo dos seus dezassete números, a estrutura é a mesma, quer quanto ao formato, quer quanto ao número de páginas de cada número. Embora não se possa falar, com precisão, de artigos de fundo, ao nível da primeira página, aqui se inscrevem alguns textos de criação literária, em prosa e verso, assim como alguns ensaios e textos reflexivos sobre temas vários. A última página é reservada, exclusivamente, à publicidade.

A existência de duas secções permanentes: «Carteira de Barcarola» ou, simplesmente, «Carteira», onde se prestam um conjunto de notícias e informações e «Horas de Recreio», com charadas, charadas às damas, enigmas e logogrifos.

O carácter literário deste periódico revela-se, não só em textos de criação, mas também em ensaios, ao nível da literatura, de que são exemplos os artigos intitulados «Uma fase da nossa literatura» de José Barros Nobre, «Simbolistas portugueses» e «Filiação do simbolismo», ambos de Moreira Nunes, onde nos dá uma visão global deste período das nossas letras. Assinala-se, também, o falecimento de António Nobre, a quem chamam «um lutador incansável pela literatura do seu país», apesar de o poeta seguir «uma escola que não era nem é a nossa» (n. ${ }^{\circ} 5$, p. I).

Reflexões também sobre criminalidade. Sendo o crime «o maior dos males sociais» (n. ${ }^{\circ} 5$, p. I), reconhece-se o papel que ao Estado e à Escola cabe neste combate. Se aquele pode regular a propriedade e contribuir para o bem-estar económico, a escola primária "por ser frequentada por todas as classes, e pelo ser na idade em que no cérebro da criança penetram os elementos da sua futura conduta» (n. ${ }^{\circ} 3$, p. II), tem um papel fundamental.

Recusando ser um artigo de crítica, em «Impressões teatrais» apresentam-se «umas ligeiras e modestas impressões sobre as coisas do teatro nesta cidade» (n. $\left.{ }^{\circ} 11, \mathrm{p} . \mathrm{VI}\right)$.

Completa-se esta publicação com Folhetins e muita poesia, Salienta-se, aqui, a que César Monteiro dedicou «A Pedro Álvares Cabral. Comemorando o 4. ${ }^{\circ}$ centenário da descoberta do Brasil». 


\title{
20 • BOÉMIA NOVA
}

\author{
Revista de Literatura e Ciência Cotas: \\ Coimbra, Tipografia União BN: J.981//3B.; J.1640//15V. \\ 1 Fevereiro $1889-12$ BGUC: O.S. 1024 \\ 1 Fevereiro 1889 - 12 Abril $1889 \quad$ BPMP: P/B/2699 \\ BMC: GHC-4
}

Redactor: Dr. Fausto (Pseudónimo de Alberto de Oliveira)

Colaboradores: António Nobre, Manuel Emídio Garcia, Pinto da Rocha, Xavier de Carvalho, Abel Acácio Botelho, Agostinho Campos, António de Melo, Sanches da Gama, Francisco Bastos (passou depois para Os Insubmissos), Carneiro de Moura, Alberto Osório de Castro, Heliodoro Salgado, João Saraiva, Alfredo Teixeira Ribeiro, A. Gonçalves, Cunha e Costa, Amilcare Cipriani, António de Menezes e Alberto Bandeira

Formato: 31,5 x $22 \mathrm{~cm}$

Periodicidade: Quinzenal

Preço: Trimestre -500 réis $\bullet$ Avulso -100 réis

Páginas: 76

\section{Objectivo}

«Em Coimbra não há propriamente vida literária, embora haja uns restos de vida académica, que as qualidades excepcionais da terra hão-de constantemente manter...

Hoje, em Coimbra, não há boémia literária, nem cenáculo, nem jornal, nem coisa nenhuma: há, pura e simplesmente, rapazes que escrevem e que publicam os seus escritos nos diversos jornais do país...

Da Boémia Nova pode dizer-se o que se diz em todas as apresentações de gazetas: - vem a preencher uma lacuna. A razão é porque, no momento actual, não há em Coimbra um único jornal académico.

Mas a Boémia Nova não vem nem pretende amparar a decadência intelectual de Coimbra, criar uma nova vida, uma nova boémia literária. Não quer ser orgão oficial da academia, nem pensa em tomar uma exagerada e inconveniente cor local.

A Boémia Nova vem apenas oferecer aos rapazes que escrevem as suas colunas; e com o estímulo de que lá por fora se apreciem, reunidos, os elementos 
literários e científicos de que aqui dispomos - vamos a ver se um pouco de entusiasmo faz nascer em todos a vontade enérgica de trabalhar.

Porque a produção literária aqui não é tão grande que possa encher quinzenalmente um jornal de dezasseis páginas, temos de recorrer também a escritores estranhos; procuraremos, no entanto, de preferência, a colaboração dos novos, e havemos de ver se conseguimos, por minuciosas crónicas do país e do estrangeiro, pôr os nossos leitores a par do importante movimento literário e científico que por toda a parte chama a atenção dos espíritos ilustrados.

É um jornal de rapazes de hoje, a Boémia Nova; procurará ser também um jornal de ideias modernas de orientação moderna, de moderníssima escola» (Bohemia Nova, n. ${ }^{\circ}$ 1, Coimbra, 1 de Fevereiro de 1889, p. 1).

\section{Conteúdo}

Num desdobramento temático podemos identificar o tratamento das seguintes questões:

- Crónicas sobre Academia e vida académica, em Coimbra;

- Escrevendo de Paris, Xavier de Carvalho e Alberto Osório de Castro dãonos conta, não só do movimento literário francês, com referências fortes ao decadentismo e simbolismo, mas também da vida galante e nocturna na capital francesa, para Amilcare Cipriani, em carta a Xavier de Carvalho, marcar «uma linha de encontro entre o movimento simbolista ou decadentista e certas intenções revolucionárias de intervenção social» (Fernando Guimarães, Simbolismo, Modernismo e Vanguardas, Porto, Lello e Irmão - Editores, 1992, p. 229).

- Artigos que decorrem da polémica com Os Insubmissos sobre problemas de métrica;

- Temas de História, sejam no domínio da História da Arte com o artigo de A. Gonçalves, «A Cripta da Sé Velha», sejam sobre a história de França com o artigo «Boulangismo e Cesarismo», de Cunha e Costa ou sobre a concepção de História como o da autoria de Manuel Emídio Garcia, «A História»;

- Carneiro de Moura em artigo intitulado «O Suicídio» reflecte sobre esta questão;

- Completam este periódico alguns textos em prosa e sobretudo muita poesia.

Bibliografia: Fernando Guimarães, Simbolismo, Modernismo e Vanguardas, Porto, Lello e Irmão Editores, 1992 


\section{1 • BOÉMIA VELHA}

Revista Crítico-Literária

Lisboa,Tipografia Bizantina

25 Março 1889
Cotas:

BN: J.325//9P.

BGUC: 10-1-15-32

BPMP: -

BMC: GHC-4

Proprietário: Zé das Gaifonas (1);

Redactor: Mephistopheles (1)

Formato: $15 \times 23,9 \mathrm{~cm}$

Periodicidade: N. ${ }^{\mathrm{O}}$ único ${ }^{(2)}$

Preço: 10 n. ${ }^{\text {os }}-400$ réis $\bullet$ Avulso - 40 réis

Páginas: 8

\section{Objectivo}

«Mais um. Em tão curto tempo, desde princípio de Fevereiro, rebentaram para aí três jornais supurando literatura indigesta...

Hoje apresento-lhes também a Boémia Velha. Prevejo que não será longa a sua vida, se lhe não for favorável o acolhimento dos leitores. Todavia cumpre já declarar que só desta circunstância favorável, principalmente, e da bolsa do proprietário, em segundo lugar, depende a sua vida, e nunca da existência dos colegas patrícios, nem dos favores das tipografias.

Tenham cuidado com esta mulher que se chama a Boemia Velha.

Inflexível como o aço, austera como a justiça... nunca falsa, tem por hábito bater onde encontra uma mazela literária. Odeia a hipocrisia reles dos poetas piegas, e não perdoa ladroeiras, sempre que as descubra, e de qualquer natureza que sejam.

74 De noite passa de fugida, pelos passeios, escutando as conversas íntimas dos grupos de boémios novos, que vão distraídos e de cabeça levantada; entra no Marques Pinto, na Havaneza, no Lusitano abanca-se com os insubmissos e boémios novos, disfarçada, colhendo insignificâncias para abrir caminhos, pe-

(1) Segundo nos informa Carneiro da Silva (ob. cit., p. 24), os redactores desta revista teriam sido Lomelino de Freitas, Delfim Gomes e Pedro Cardoso.

(2) Anunciava-se que sairia duas ou três vezes por mês. 
netra, em algumas noites, numas casas que há espalhadas pela Alta, uns antros infectos, onde muitos pobres rapazes perdem a saúde e a mezada.

Nada lhe escapa...

Pelo que fica dito, leitores, podeis construir aproximadamente o nosso programa» (Boémia Velha, n. ${ }^{\circ}$ 1, Coimbra, 25 de Março de 1889, p. 1).

\section{Conteúdo}

No contexto da imprensa periódica estudantil coimbrã, um aspecto importante a ter em conta é a crítica que os diferentes grupos e publicações faziam uns aos outros. De entre outras razões, a vocação satírica estudantil e a rivalidade literária são apontadas, muitas vezes, como causas dessa mesma crítica. Certamente por isso, Boémia Velha, logo no seu texto de apresentação, afirma que «tem por hábito bater onde encontra uma mazela literária».

Neste ano de 1889, duas revistas coimbrãs, Insubmissos e Boémia Nova, disputavam, no âmbito da literatura portuguesa, a primazia na introdução de novas experiências rítmicas e estilísticas, fazendo eco de nomes sonantes das letras francesas.

A revista Boémia Velha (nome de oposição a Boémia Nova) aparece enquadrada nesta polémica. Daí que o seu conteúdo seja, fundamentalmente, uma crítica, por vezes parodística, à revista Boémia Nova. Fazem-se críticas e reflexões aos escritos de Alberto de Oliveira, a quem tratam por «Albertinho de Oliveira» (p. 2, col. 1), Carneiro de Moura, Alberto Osório de Castro e António Nobre, entre outros. Criticando, por exemplo, o artigo «O Suicídio» de Carneiro de Moura, a quem chamam "original boémio" (p. 6, col. 1), dizem: «Não queira impingir ideias triviais, recomendadas por uma linguagem horrivelmente difusa e misteriosa, comprimidas pelo peso desmesurado de palavras quilométricas e bojudas, que as vedam aos olhos dos mortais» (Idem, p. 6, col. 1).

Questionando-se, também, António Nobre, em Boémia Nova, sobre "Que hei-de fazer, Senhor! o que é que espera um bacharel formado...?», a resposta a este pensamento é dada prontamente e nos seguintes termos de chacota e risada: «Ora o que há-de fazer?... pinos e linhas - ou ir à fava...» (Idem, p. 8, col. 1).

Bibliografia: Fernando Guimarães, Simbolismo, Modernismo e Vanguardas, Porto, Lello e Irmãos Editores, 1992 
Jornal que todo o bom caloiro deve ler

Cotas:

Coimbra, [s.1.]

12 Outubro 1895 - 24 Março $1896^{(2)}$

$\mathrm{BN}$ :

BGUC:

BPMP:

BMC: G.H.C-3

Colaboradores: Alberto Bastos, Canavarro Valadares e Afonso Botelho ${ }^{(2)}$

Formato: 13,5 x $21 \mathrm{~cm}$

Periodicidade: Não indica

Preço: Não indica

Páginas: 4

\section{Conteúdo}

Segundo Carneiro da Silva, trata-se de um jornal, copiografado, de estudantes do liceu, do qual se publicaram doze números (Cfr. Ob. cit., p. 24). Por sua vez, Pinto Loureiro, referindo-se a este periódico, diz-nos que não sabe «onde exista qualquer número» (Jornais e revistas de Coimbra, Ed. da Biblioteca Municipal, Coimbra, Coimbra Editora, 1931, p. 9, col. 2). No entanto, na Biblioteca Municipal de Coimbra existe apenas o n. ${ }^{\circ} 8$ deste jornal, com a data de 13 de Fevereiro de 1896. Trata-se de um número muito simples e muito modesto e sem interesse de maior. Para além de uma «Crónica», onde se relata a ida da tuna académica à Figueira da Foz, dá-nos conta do aparecimento e do programa da revista $A$ Miniatura e do sarau realizado no Ginásio de Coimbra. A página 3 é ilustrada com desenhos, cujo título é «Teimosos».

Completa-se com o habitual «folhetim» e um enigma.

(1) Consultou-se apenas o n. ${ }^{\circ} 8$ deste periódico, por ser o único existente na B.M.C.

(2) Segundo informação de Carneiro da Silva, ob. cit., p. 24. 


\section{3 - BOFETADAS}

Coimbra, Imprensa Académica

Abril 1896 - Maio 1896
Cotas:

BN: J.1264B; J.972//2P

BGUC: O.S. 101-102

BPMP: -

BMC: G.H.C-19/1

Director: Alexandre de Albuquerque (Xandre)

Formato: $10,5 \times 16,5 \mathrm{~cm}$

Periodicidade: Mensal

Preço: 50 réis - o n. ${ }^{\circ} 1 \bullet 30$ réis - o n. ${ }^{\circ} 2$

Páginas: 16

\section{Objectivo}

«De escapada para aldeola a férias dei comigo em Aveiro, na feira de Março, muito concorrida pela ganância...

Ao fundo da feira, da banda das marinhas, uma meia dúzia de barracões... e o pim-pam-pum em uma barraca mais pequerrucha, mais acanhada... onde, com aplauso da turba zaragateira, alguns pimpões de lesto pernil praticam a cobardia do ataque à surrelfa, como os panfletários anónimos...

Um petiz atira certeiro os badamecos do Pim-Pam-Pum com as bolas...

É o que vamos fazer, com mira, a uns certos, o que não impede de, quando em quando, saltarmos aos burgueses aparrados aos pequenos malandrotes, fêmeas dengosas, velhos cambaios e burocratas bonacheirões, não esquecendo o parrana, pançudo do arcaboiço e retundo do bestunto, que é nosso amo, com grande satisfação do Zé-povinho e não menos das suas respeitabílissimas enxundias.

Quisemos abrir uma barraca de Pim-Pam-Pum, para os expormos à assuada do público, mas quando estávamos a enfileirá-los, tão ridículos nos pareceram, que deu-nos a gana e desatámos à lambada» (Bofetadas, n. ${ }^{\circ}$ 1, 1896, pp. 1-3).

\section{Conteúdo}

À semelhança de muitas outras, Bofetadas é uma pequena publicação que se insere num tipo de periodismo, muito cultivado pela Academia, que, por 
analogia com a literatura, podemos classificar de escárnio e maldizer. É, por isso, uma publicação virada, fundamentalmente, para o interior da Academia.

A par da denúncia de um certo espírito burguês na sociedade, o conteúdo desta publicação centra-se, essencialmente, na crítica a vários estudantes (citam-se os nomes), em virtude, não só do seu pedantismo e maneira como se apresentam, mas sobretudo por causa da sua «literatice» e pseudo-intelectudalidade. Da poesia de Henrique de Vasconcelos diz-se: "publicou umas caganifâncias em prosa-rimada à laia do Rei de Madureza. Versos que não são versos, que nem para calendário de tabacaria servem...» (n. ${ }^{\circ} 1$, p. 14). 


\section{4 - BOLETIM DA SOGIEDADE DO NÍVEL OFERECIDO À ACADEMIA}

(publicado por uma numerosa comissão de terceiranistas amantes das glórias nacionais)

Coimbra, Imprensa de E. Trovão

Fevereiro de 1899
Cotas:

$\mathrm{BN}$ : -

BGUC: -

BPMP: -

BMC: GHC-2

Formato: $13,7 \times 20 \mathrm{~cm}$

Periodicidade: N. ${ }^{\circ}$ único

Preço: 50 réis

Páginas: 20

\section{Objectivo}

«O nosso intuito, ao darmos à luz da publicidade este boletim, é levantar bem alto, tanto quanto as nossas minguadas forças o permitam, esse grupo de rapazes que, abandonando o dolce far niente que, em geral, a todos domina, se dedica de alma e coração a uma obra santa, qual a de levantar o nível moral e intelectual da Academia e especialmente do curso do $3 .^{\circ}$ ano jurídico.

Nós, terceiranistas de direito, cônscios da grandeza de tal tarefa e abarrotados de gratidão, vimos, por este meio, tornar conhecidos da Academia alguns dos capítulos do laborioso parto intelectual de tão preclaros moços.

Embrulhados no manto adorável da modéstia, sem dúvida continuarão esses apóstolos do Bem e da Ciência a sua obra de regeneração, visto o que nós prosseguiremos no caminho hoje encetado, dando à publicidade os formosos discursos e as jóias literárias que, até agora, injustamente se tem furtado à admiração das gentes.

Pouco é o que neste boletim publicamos, em virtude do horror mal cabido que os adoráveis mancebos têm à celebridade, prometemos porém apresentar, nos boletins futuros, mais alguns dos cerebrinos produtos de $\mathrm{S}$. Ex. as além de um poema em que a gratidão de nós todos se espelhará límpida e sem mácula.

Frequentaremos, para tal fim, a sede da sua sociedade, na rua de Corpo de Deus, n. ${ }^{\circ}$ 60, e esperamos em Deus que, para bem da Ciência e da Academia alguma coisa consigamos» (Boletim da Sociedade do Nível..., p. 3). 


\section{Conteúdo}

Em 1899, treze estudantes fundaram, em Coimbra, uma sociedade que chamaram de Amicitia e cuja finalidade era promover uma certa união entre académicos. À noite, em vésperas de feriado, os seus membros reuniam-se numa casa, na Rua do Corpo de Deus. Então, o tempo era aqui preenchido «por leituras de versos e trabalhos literários dos associados, por conferências sobre assuntos sociais, religiosos, históricos, conforme as tendências de cada um» (Francisco de Athayde Machado de Faria e Maia, A minha velha pasta (Tempos de Coimbra e gente do meu tempo) 1896-1901, Ponta Delgada, Tipografia Diário dos Açores, 1937, p. 53).

Alguém, malevolamente, levantou o boato que esta sociedade pretendia levantar o nível intelectual e moral da Academia. Daí toda uma campanha de troça em redor da sociedade e seus fundadores.

Para defender este grupo de estudantes surgiu, então, O Boletim da Sociedade do Nível "publicado por uma numerosa comissão de terceiranistas amantes das glórias nacionais».

Trata-se de um número único que, depois de um «Avant propôs», de um texto assinado por Duque de Espinho-Feira e de «Duas Palavras», a servirem de apresentação, comporta três textos bastante jocosos, a servirem de âmago à própria publicação, traduzindo assim o sentido de resposta que animou a publicação do periódico.

Anexo a esta publicação encontra-se um manifesto dirigido à Academia, datado de 20 de Fevereiro de 1899, assinado pelos treze sócios, e que rebate os boatos levantados.

Bibliografia: Francisco de Athayde Machado de Faria e Maria, A minha velha pasta (Tempos de Coimbra e gente do meu tempo) 1896-1901, Ponta Delgada, Tipografia Diário dos Açores, 1937; Alberto Costa, O Livro do Doutor Assis, 9 ${ }^{\text {a }}$ ed., Lisboa,Livraria Clássica Editora, 1945; Alberto Sousa Lamy, A Academia de Coimbra 1537-1990. História. Praxe. Boémia e Estudo Partidas e Piadas. Organismos Académicos, Lisboa, Rei dos Livros, 1990, pp. 156-57. 


\section{5 • O BRASILEIRO EM COIMBRA}

Coimbra, Imprensa da Rua dos Coutinhos

3 Abril 1823

Redactor: Cândido Ladislau de Figueiredo ${ }^{(1)}$

Formato: 19,5 x $29 \mathrm{~cm}$

Periodicidade: N. ${ }^{\circ}$ único

Preço: 50 réis

Páginas: 4
Cotas:

BN: -

BGUC: FOTOC. 96

BPMP: -

BMC: GHC-4

\section{Objectivo}

«Ora pois, meus compatriotas (refere-se aos estudantes brasileiros), disponho-me a escrever para o público! Teremos também o nosso papel, para dizermos, por meio da imprensa as nossas verdades sempre desfiguradas e mesmo envenenadas neste país em que habitamos. É preciso dizer ao público de Portugal os nossos sentimentos, já que ele pensa que nós somos carcundas somente por querermos ter representação no mundo político. Vocês bem sabem que o amor da Pátria é quem me obriga a escrever... É preciso que vocês todos me ajudem, porque a causa é de todos... Ninguém duvida que da verdade ou falsidade das notícias políticas depende a felicidade ou desgraça não só do Brasil, mas até de Portugal. Cumpre-nos portanto não só dizer ao Brasil o que se passa em Portugal; porém ainda dizer a Portugal o que se passa no Brasil.

O português sabendo com exactidão as forças e os progressos do Governo brasilico não quererá arriscar os seus soldados e o seu dinheiro contra um país que não pode e nem poderá jamais conquistar; o brasileiro sabendo com exactidão o que se passa em Portugal, escusa fazer esforços para receber imaginados conquistadores.

Ainda que eu não seja um político, contudo não me contentarei só em ser um correio de novidades; algumas vezes também lembrarei daqui aos nossos

(1) Este nome consta na declaração manuscrita e assinada por Joaquim Martins de Carvalho que se encontra anexa ao exemplar existente na Biblioteca Municipal de Coimbra. 
brasileiros alguma coisa que lhes convenha; e tudo será ditado por o amor que lhes tenho. Reflexões políticas sobre o Governo interno e externo de Portugal só terão cabimento neste papel assim que tiverem relação com o nosso. Se forem boas, aproveite o nosso Brasil; se o não forem, fiquem no esquecimento... Também é meu ardente desejo que os patrícios se não acharem bem escrito este meu papel, escrevam outro; porque o meu fim não é ostentar de escritor; o meu fim é que a Pátria tire alguma vantagem dos seus filhos que manda instruir nesta Atenas Lusitana.

Aos Portugueses. Portugueses livres! Aqui tendes um brasileiro livre de coração. Vós não podeis odiar minhas verdades; que os escravos as odeiem é minha glória» (O Brasileiro em Coimbra, n. ${ }^{\circ}$ 1, 1823, pp.1-2).

\section{Conteúdo}

Trata-se de um pequeno jornal, de que se publicou apenas este número e do qual, segundo Joaquim Martins de Carvalho, há muito poucos exemplares (Cfr. O Conimbricense, n. ${ }^{\circ}$ 6171, de 29 de Janeiro de 1907), em virtude de este mesmo periódico ter sido logo apreendido, por causa do seu autor aí defender a separação do Brasil de Portugal.

A liberdade do povo brasileiro é defendida e sustentada no artigo intitulado «Ao Senhor Campeão Lisbonense».

Completa-se este periódico com uma carta datada de 7 de Novembro de 1882, de uma menina baiana, onde se dá conta não só das atrocidades que os «soldados lusitanos» estão a cometer naquela região do Brasil, mas também do espírito que anima os brasileiros e um apelo às mulheres brasileiras convidando-as à resistência, porque "o peito de uma brasileira, que serve de santuário ao amor, sirva também de escudo à Liberdade da Pátria» (p. 4, col. 2). 


\section{6・O BURRO}

Jornal Bimensal, crítico-burlesco e de caricaturas

Cotas:

Coimbra, Imprensa da Universidade

$\mathrm{BN}$ : -

1865

BGUC: -

BPMP: -

MC: GHC.-152-S

Redactor: António Alves Ribeiro ${ }^{(2)}$

Formato: 28 x $43,5 \mathrm{~cm}$

Periodicidade: Bimensal

Preço: Ano - 960 réis

Páginas: 4

\section{Objectivo}

«Esquisito título! e à primeira vista digno de riso! Mas não é: hoje, que os melhoramentos materiais dão ao homem tantas horas desocupadas, este, em vez de as empregar no aperfeiçoamento moral do espírito, gasta-as com os mais infames tramas e abomináveis negócios, em que põe em almoeda honras e consciências! Parece inacreditável que, à medida que os princípios da mais sã moral são proclamados, que a filosofia do mártir do Gólgota é reputada a melhor, na prática sejam os actos humanos a sua degeneração completa!

Se, fechando os olhos para o progresso do século, os abrirmos só para as torpezas que o mancham, dir-se-á que o caminhar do tempo está na razão inversa do progresso das luzes.

Apregoa-se a igualdade, fraternidade e liberdade, e entre os que a apregoam vê-se a mais crapulosa soberba, o mais abjecto egoísmo e a mais refinada tirania.

Porquê? Faltam por ventura ao homem os elementos para seguir a estrada do bem? Falta-lhe tempo para aprender o código do dever?

Não: pelo contrário, sobeja-lhe, e o código do dever está há dezanove séculos proclamado!

(1) Não chegou a publicar-se. Saiu apenas o prospecto.

(2) Apesar de não chegar a publicar-se, segundo Carneiro da Silva fazia parte da redacção o estudante António Alves Ribeiro (Ob.cit., p. 33). 
Castigue-se pois! não com o azorrague, cujas vergoadas se apaguem com o tempo, mas por outro meio desonroso, que os fira no orgulho, que lhes lembre o castigo para fugirem do mal, que os cubra de ignomínia. Assim talvez se faça alguma coisa.

Lembrem-se! é um burro que os castiga; é o animal, vosso escárnio eterno, que nos diz a estrada que deixastes, e aquela que deveis seguir.

Sem piedade, pois, se persistirem no mesmo caminho! Eis o fim do Burro. Fustigando os vícios, cubrindo de ridículo as misérias da sociedade, este jornal não tem em mira mercancia nem ganhos.

Os R.R. (Republicanos?) querem pôr em prática as virtudes que apregoam - querem poder dizer alto e bom som o que é filantropia e o que é caridade, o que é virtude e hipocrísia; isto sem lhes poderem atirar às faces nenhum apodo ou injúria.

Das assinaturas que $O$ Burro tiver, $20 \%$ do seu produto é destinado a ajudar os estabelecimentos pios e instituições de caridade; do resto tirará as suas despesas, e os lucros, se os houver, ainda 5\% serão para as mesmas instituições.

O produto dos anúncios é para socorrer famílias desvalidas.

Das assinaturas que alguém promover pode fazer presente a qualquer associação de beneficiência para delas tirar o oferecido lucro. Como brinde será dado aos senhores subscritores anuais um romance original de um dos nossos mais ilustres escritores.

Pode dizer-se que este jornal quer ganhar? pode dizer-se que ele quer fazer dos vícios do século modo de vida ou receita?

Não.

Assim, O Burro terá as orelhas cada vez mais atentas, os olhos mais abertos e as terríveis armas sempre prontas para castigar os maus.

O Burro, do formato deste prospecto, com três páginas de impressão e a quarta de caricaturas, sairá nos dias 15 e 30 de cada mês» (Prospecto). 
27 • O GÁBULA (1)

Coimbra, Tip. Rua da Sofia

Cotas:

5 Novembro 1899

BN: -

BGUC: -

BPMP: -

BMC: GHC-4

Editor: J. J. de Andrade Freire;

Redactor: Guilherme de Albuquerque ${ }^{(1)}$

Formato: $26 \times 11 \mathrm{~cm}$

Periodicidade: Semanal ${ }^{(2)}$

Preço: Mês -200 réis • Avulso - 50 réis

Páginas: -

(1) Não chegou a publicar-se, tendo-se distribuído apenas o prospecto. Segundo Carneiro da Silva, teria como redactor Guilherme de Albuquerque, aluno do liceu (Ob. cit., p. 34).

(2) Por baixo do título lê-se a informação de que este periódico se publicava às quartasfeiras. O termo quarta-feira está riscado. Em seu lugar, corrigido a mão, escreveu-se domingo. 
$\begin{array}{ll}\text { Folha Recreativa } & \text { Cotas: } \\ \text { Coimbra, [s.1.] } & \text { BN: - } \\ 1878 & \text { BGUC: - } \\ & \text { BPMP: - } \\ & \text { BMC: GHC-20/10 }\end{array}$

Formato: 22,5 x $32 \mathrm{~cm}$

Periodicidade: -

Preço: Assinatura mensal - 100 réis

Páginas: -

\section{Objectivo}

«O Caloiro é propriedade dos estudantes de preparatórios; assim como $A$ Academia é direito reservado aos estudantes que frequentam a Universidade Portuguesa.

Nós, porque somos caloiros; porque o nosso nome quase se confunde com a rudez mais crassa, devemos sufocar o génio e o talento?

É lícito que... quand le monde marche, como dizia um sábio, nós fiquemos inertes, mergulhados na indolência e estupidez, vendo avante a luz do progresso? Nunca! Nunca!

Raiou enfim a aurora literária: saudemos o novo sol, que sorri a todos e brademos entusiastas, abrindo o nosso porto, ainda que humilde e pobre, aos náufragos da ciência!» (O Caloiro, prospecto).

(1) Este periódico não chegou a publicar-se. Foi distribuído apenas o prospecto a anunciá-lo, pelo que os elementos aqui coligidos dizem respeito, somente, ao prospecto. Os seus autores vieram, em 1879, a publicá-lo, mas com o nome de $O$ Astro da Juventude. 
Folha humorística semanal

Coimbra, Tipografia do "Caloiro» (2)

30 Abril 1882 - 15 Maio 1882
Cotas:

$\mathrm{BN}$ :

BGUC:

BPMP:

BMC: GHC-4

Colaboradores: Gato, Formigão, Lobo, Riloco

Formato: $13 \times 20,5 \mathrm{~cm}$

Periodicidade: Semanal

Preço: Assinatura-mês-80 réis • Avulso-30 réis

Páginas: 4

\section{Objectivo}

«O Caloiro é um jornal dedicado somente ao riso de todos. O Caloiro é um livro que está por formar, mas que se irá coordenando folha a folha com anedotas, artigos, poesias, caricaturas, etc.

Tem por política: a verdade e a polémica.

Aceitará a colaboração de todos, mas só publicará o que for digno nas lides do jornalismo.

Em todos os originais que forem remetidos à redacção, haverá o mais rigoroso exame...

O Caloiro contem duas páginas impressas a tipo, e duas de caricaturas...» (n. ${ }^{\circ} 1$, p. 1).

\section{Conteúdo}

Trata-se de uma modestíssima publicação, sem grande interesse, e que, nas palavras dos seus responsáveis, tem como intuito fundamental fazer rir.

(1) Dado não nos ter sido possível identificar os pseudónimos dos colaboradores e sem outras informações, temos algumas dúvidas sobre o carácter desta publicação. É possível que seja um jornal estudantil. A contrária poderá ser também verdadeira. Na dúvida, optou-se pela sua inclusão, até pelo seu título.

(2) Imprimiu-se na Tipografia Santos e Silva. (Cfr. O Conimbricense, 11 de Julho de 1908, p. 3, col. 4). 
A colecção completa deste periódico é de três números, todos idênticos.

Para além da publicação de algumas poesias, este jornal centra as suas atenções na figura do Marquês de Pombal, até porque decorria o centenário da sua morte.

Elogiando a obra do grande estadista, criticam-se severamente os jesuítas e, sobretudo, o jornal a Ordem, «que saíu no dia 6 toda tarjada de preto fazendo injúrias ao Marquês de Pombal» (n. ${ }^{\circ}$ 2, p. 2).

A pouca simpatia por aqueles é tal que, em verso, canta-se assim:

«Aqui jaz um jesuíta

Que não largou a maldição;

Por vícios todos do mundo

Só lhe faltou ser ladrão!» (n. ${ }^{\circ}$ 3, p. 2)

Completa-se este periódico como uma secção de «Variedades», que é um lugar de ditos e chalaças. 


\section{0 - GAOS}

(1)

1858

Redactor: João de Deus ${ }^{(2)}$

Formato: 12,7 x $20 \mathrm{~cm}$

Periodicidade: -

Tiragem: 10 exemplares

Preço: não indica

Páginas: 8
Cotas:

BN:

BGUC:

BPMP:

BMC: GHC-4-S

\section{Objectivo}

«Mais uma folha da árvore da vida - O Chaos. Nasce para todos o sol. Deus o cerque de benevolência e abram-lhe os homens o seio da hospitalidade.

Luz e ideia são irmãs gêmeas, e a Deus se assemelham como filhas suas, que são, e primogénitas. Nenhuma das suas obras o aclama tão alto: acende-se a lâmpada e enche-se de luz a casa; concebe-se a ideia e os lábios soltam-na expansiva como o braço que encheu o céu de estrelas: se as prendem, morrem: todo o seu ganho é dissipar, toda a sua riqueza, consumir. Tapai a boca, matais o espírito: fechai a luz, a luz apaga-se. Imagens fiéis e vivas do grande Sopro, a luz e a ideia respiram só no alto da montanha donde se avistam todos os reinos da terra...

A poesia é a língua de Deus, e a medida dum verso, o diâmetro do mundo.

Tudo o que é de Deus é assim - espaço e liberdade. Encarcerai o homem dentro em si só; ei-lo mais vil que a rocha...

Todo o amor é pródigo, irradiante e dissipador, centrífugo como a luz, como a ideia; e Deus é todo amor. Deus nunca fecha os olhos para só ver o que vai

(1) Em nota, na p. 2, lê-se: «O artigo que publicamos em folheto é transcrito do Repositório Literário, jornal que se publicou nesta cidade em 1868. Foi escrito para servir de introdução a uma folha literária que com o título - Chaos - o grande poeta João de Deus tentou publicar nesta cidade, quando estudante.

Como não vem inserido no volume intitulado - Prosas - resolvemos fazer dele uma tiragem apenas de 10 exemplares».

(2) Carneiro da Silva, ob. cit., p. 35-36. 
dentro em si e contar como avarento os tesouros da sua grande alma. Em seis dias legou quanto possuía: no sétimo descansou ao ver-se pobre.

Nessa partilha universal a nós coube-nos uma faísca dos seus olhos; não deixemos apodrecer a sagrada relíquia: conservamo-la viva, ao menos se não, pura. O alimento da alma é a ideia, pensemos: a respiração da alma é a palavra; falemos: se não para a vida dos outros, para a nossa própria...

O sol sobe à montanha e afoga a terra em luz... Mas o sol passa; a luz some-se pela terra dentro... e o homem diz «é noite!».

Engano.

«Da manhã e da tarde fez Deus um dia» diz lá Moisés...

Noite - é a palavra dos homens: o olho universal vê sempre o sol em pino... Os pais não dormem...

Por mim, filho de Deus e irmão dos homens, irei de hoje em diante pôr, alta noite, à cabeceira dos meus companheiros de exílio um segredo, uma consolação, uma esperança, uma flor, um beijo, uma saudade! Do seu lhes dou: que há no homem que não seja de todos? Mas se de todos é tudo para o prodigalizarmos também em todos gira o sangue do mesmo Pai!...

Todo o sofrimento ficou santificado depois de Cristo, e todo o crime, expiado...

Esta a nossa fé e a nossa esperança.

Este, o Chaos, é o seu destino» 


\section{1 • O CAUTÉRIO}

Ridendo Castigat Mores. Semanário Ilustrado

Coimbra, Tipografia Luís Cardoso

12 Novembro 1899 - 19 Novembro 1899
Cotas:

$\mathrm{BN}$ : -

BGUC: -

BPMP: -

BMC: GHC-21/1-S

Editor: Manuel Paulo

Redactores: Almarcar, Cortalupus e Escalpelho ${ }^{(1)}$

Formato: 27 x $39 \mathrm{~cm}$

Periodicidade: Semanal

Preço: 3 meses -250 réis $\bullet$ Avulso - 20 réis

Páginas: 4

\section{Objectivo}

«O Cautério tem por fim seguir o caminho da verdade e da justiça, censurando com aspereza aqueles que o merecem, tomando, na maioria dos casos, essa censura a forma humorística.

Tem, como emblemas, o escalpelo, com que há-de analisar os fenómenos sociais, o ferro em braza, com que há-de castigar os que desprezam os princípios da dignidade e da honra, e uma mulher, iluminando tudo, que é a crítica serena e desapaixonada, essencial para se chegar ao descobrimento da verdade.

O Cautério não se esquecerá que nem todos os erros e vícios, que campeiam impunemente, merecem o látego da mais severa crítica... É um jornal de combate e espera lutar com energia sim, mas também com decência.

O chefe de família não verá, neste periódico, doutrinas que produzam abalo nos alicerces desse santo e maravilhoso edifício que se chama o lar doméstico, e a donzela mais pura não terá de corar ao ler o Cautério...

É um jornal de estudantes, mas também terá a colaboração de escritoras e escritores, que não pertencem à academia... É principalmente para o povo que escrevemos, para o povo, do qual tantos falam com entusiasmo e a quem tão

(1) Carneiro da Silva (ob. cit., p. 37) fala-nos nos estudantes Costa Cabral, Mário Henriques e Alberto Martins de Carvalho como sendo os redactores deste periódico. 
poucos ligam importância. Ligam-lha sim, em vésperas de eleições, para ele servir de escada inconsciente a ambiciosos sem escrúpulos, e para o obrigarem a pagar mais impostos...

O Cautério não servirá os interesses de um partido e lançará mão da caricatura, como meio mais fácil do público fixar e compreender ideias, que devem estar no espírito de todos. Rindo, dirá verdades, pois a rir se podem fazer afirmações justas e consagradas pela experiência.

Será sincero, e num tempo de tanta hipocrisia, como o actual, parece-lhe que isto terá algum valor, algum merecimento» ( $O$ Cautério, n. ${ }^{\circ} 1,12$ de Novembro de 1899, p. 1).

\section{Conteúdo}

À semelhança de muitos outros, este pequeno jornal estudantil, de carácter humorístico, insere-se naquele tipo de periódicos que podemos classificar de escárnio e mal-dizer. Para além da caricatura, do desenho e da gravura, estas publicações caracterizam-se também pelo anonimato e pela ironia, procurando, fundamentalmente, divertir, fazendo rir, mas sem intenção de molestar fosse quem fosse. De uma maneira geral, $O$ Cautério não foge a esta regra.

A sua estrutura é sensivelmente a mesma nos dois números, quer quanto ao formato, quer quanto ao número de páginas.

Profusamente ilustrado, sobretudo o primeiro número, os seus autores fazem uma crítica, não só à política nacional e internacional (Ex.: «Romaria Eleitoral» e «Deus salve as repúblicas unidas do Transval e de Orange»), a atitudes e posturas (Ex.: «D. D. Juans Modernos»), mas também ao que se vai passando em Coimbra, seja sociedade académica ou civil, consubstanciado, muitas vezes, na rubrica de «Lição da Semana».

Completa-se este jornal com alguma poesia e folhetim. 


\section{2 • O GENÁGULO}

Revista Crítica e Literária

Coimbra, Tipografia de Luís Cardoso

1 Dezembro 1894 - 15 Março 1895
Cotas:

BN: J.979/ /6P;J.1282B

BGUC: -

BPMP: $\mathrm{X}^{3}-10-51$

BMC: GHC-2-S

Redactores: Gonçalves Cerejeira, Vilela Passos, Augusto Granjo

Colaboradores: Avelino de Oliveira, Manuel Mendes, Mariano Garcias, Israel Ivope, Rodrigo da Cunha,

Severo Portela

Formato: 14,5 x $20 \mathrm{~cm}$

Periodicidade: Quinzenal

Preço: Avulso - 50 réis $\bullet$ Assinat. Trimestre -300 réis

Páginas: 100

\section{Objectivo}

«O Cenáculo não vem a aflar de pruridos messiânicos, com pretensões de levantar celeuma na arena gralhadora das letras pátrias. Cônscio da sua modesta condição, não aspira ao pináculo onde se assentam os próceres da nossa república literária. Não enverga trajes de gala; veste um hábito singelo, sem atavios mirabolantes...

Não é árvore frondosa onde se possam colher maduros pomos de arte e ciência, pois não firmam esta publicação nomes consagrados pelas lauréolas de uma reputação feita no campo das letras...

No drama lugente da Paixão, mostra-nos o cristianismo o edificante quadro da Ceia, onde doze filhos do povo, obscuros e humildes, receberam com o pão do seu fraternal convívio, a comunhão do ideal salvador emanado dos lábios abençoantes do Cristo, para, numa época em que o mundo declinava, num pélago de misérias e torpezas abdomináveis, levarem a toda a parte o verbo galvanizante de uma renovação social, num apostolado de crença e martírio, de amor e santidade...

Assim esta modesta publicação, apelidando-se $O$ Cenáculo, não pretende impôr-se como prosseguindo uma missão social de tão elevado alcance. Tem apenas em vista significar, com este título, que parte de uns poucos de moços entusiastas, irmãos pela amizade, irmãos pelas tendências, que nas suas reuni- 
ões fraternais, nos seus serões íntimos, longe das abominações de uma sociedade decadente e apática, como que celebram os cenáculos em que comungam o trigo do seu Ideal estético, filosófico e social...

Aparecendo num período de dissenção crítica da nossa literatura, em que, no meio de agitadas flutuações de escolas e processos literários, nada se acha normal e seguramente constituído, estádio talvez de incubação... esta pequena revista está fora, completamente fora dessas variadas e antinómicas escolas que aí se degladiam no campo das letras. $\mathrm{O}$ que não quer dizer que venha fundar uma escola nova. Longe disso, reprova todo o exclusivismo de escolas; a todas abre as suas páginas, para nenhuma adoptar definitivamente. Nem novos nem velhos, na significação que se está dando a estes termos. Nem decadentes, nem simbolistas, nem românticos, nem nefelibatas. Cada um será o que o seu temperamento estético lhe indicar que deve ser, nos domínios da arte... (O Cenáculo, n. ${ }^{\circ}$, Coimbra, 1 de Dezembro de 1894, pp. 1 - 4).

\section{Conteúdo}

O Cenáculo é uma pequena revista de carácter literário, de crítica e de reflexão, onde a uma concepção positiva do progresso se opõe uma concepção idealista, de raízes ético-religiosas, testemunhada, logo, nas palavras que lhe servem de apresentação.

Composta por seis números, reunidos num volume que totaliza cem páginas, mantém, em termos de formato, sempre a mesma estrutura; também o número de páginas é igual em todos os números, excepto no último, onde se verifica um ligeiríssimo aumento, mas sem qualquer significado.

A existência, embora não em todos os números, da secção «Bibliografia», onde se dá conta das publicações recebidas acompanhadas, por vezes, de uma 94 breve apreciação.

Em $O$ Cenáculo se dão a conhecer, em prosa e verso, textos inéditos e excertos de livros em preparação ou com saídas iminentes do prelo de que são exemplos títulos como: «Jornal d’um excentrico», «Getsemani» e «Idílio Vesperal».

Reconhecendo o estado de decadência do nosso país, tecem-se críticas gerais à sociedade. Mas, porque se trata de uma revista literária é, fundamentalmente, no domínio das letras que estas críticas mais se fazem sentir. Critica-se o pano- 
rama que vai na nossa literatura, onde se escrevem «livros que a gramática e o bom senso repelem com razão» (p. 9). Críticas, igualmente, para o facto de os catálogos e os escaparates das nossas livrarias serem dominados por autores e livros franceses, «transformando-se os nossos homens de letras nuns casquilhos de monóculo e nuns literatos à Verlaine» (p. 10).

Cheios de aspirações e entusiasmo, estes jovens recusam afinidades e simpatias com qualquer escola literária, seja ela dos nefelibatas, simbolistas ou decadentistas. E, porque o anarquismo é, nas palavras destes jovens, o produto lógico «da corrente positivista e materialista que atravessa a sociedade contemporânea» (p. 28) e, em parte, é a doutrina que melhor legitima e caracteriza aquelas tendências, repudiam-no no artigo de reflexão intitulado «A génese do anarquismo".

Para estes jovens, ser um «novo» literato queria dizer «regeneradores austeros da nossa literatura e da nossa pátria» (p. 11). Daí o pedido para se estudarem «os nossos costumes e usanças nacionais» (p. 11), de que o nosso teatro e as nossas tradições populares podem ser exemplos e matérias a estudar e reflectir. 


\section{3 - GENSOR PROVINGIANO}

Periódico Semanário de Filosofia, Política e Literatura

Coimbra, Imprensa da Universidade

7 Dezembro 1822 - 22 Fevereiro 1823
Cotas:

BN: J.2B; P.P. 6990P.

BGUC: $10-9-19-81$; $9-(3)-40$

BPMP: $\mathrm{N}-4-6$;

$\mathrm{VR}-\mathrm{P}(\mathrm{A})-10$

BMC: GHC -2

Director: José Pinto Rebelo de Carvalho

Formato: $10 \times 15 \mathrm{~cm}$

Periodicidade: Semanal

Preço: Trimestre -720 réis $\bullet$ Avulso - 80 réis

Páginas: 190

\section{Objectivo}

«Se algum estudo das Ciências, a que por seu gosto foi levado, se alguma lição de Literatura, e mais ainda um inato e decidido amor pela causa sagrada da Liberdade e da Justiça fossem títulos suficientes para escrever para o público, não recearia nada o Censor Provinciano entrar na tarefa de jornalista... Mas ainda que os necessários atributos lhe faltem, ele ousa lançar-se nos braços do seu destino. Homens de saber lhe têm feito indulgência de alguns. Ensaios Literários... e só deles aprecia os sufrágios o Censor Provinciano, e mais que tudo a estima dos verdadeiros amantes da Constituição, árvore sublime, de que já colhemos tantos frutos. Ainda que fraco soldado, o Censor Provinciano combaterá sempre debaixo de suas bandeiras; e por consequência a verdade e a justiça serão os seus únicos objectos.

Sobejos motivos são estes de prever desde já muitos inimigos; mas o Censor Provinciano tem por glória, que o sejam seus os que o forem da Constituição e da felicidade do povo português.

Daqui se pode coligir que o Censor Provinciano não vai tentar em sua carreira o vender muitos exemplares de seu jornal... Mas o Censor Provinciano mostrará que o seu fim é mui diverso; e que assim como não aspirará jamais às honrarias de adulador, também nunca descerá à baixeza de vil calúnia: todas as vezes que for menos exacto, então mesmo forcejará por descobrir a verdade; e quando ela lhe for patente, não hesitará um momento em abraçá-la» (Censor Provinciano, Coimbra, Imprensa da Universidade, 1822, pp. 1-2). 


\section{Conteúdo}

Elogiando o aparecimento de $O$ Censor Provinciano alguém disse que se tratava de um periódico «amante da Liberdade e da Constituição, como me dizem que é seu redactor» (n. ${ }^{\circ} 1$, p. 16). Organizado e redigido por José Pinto Rebelo de Carvalho, estudante de Medicina, este periódico pretende, não só fazer a afirmação e a divulgação das ideias e realizações, que o novo regime político, instaurado em Portugal, tem levado a efeito, uma vez que, se o homem ilustrado não necessita desta informação, já «a classe mais numerosa da sociedade não tendo essa opinião, precisa que lha dêem» (Idem, p. 5), mas também denunciar os detractores do regime constitucional, a quem chamam de «corcunda» ou "carcunda» e que definem como sendo o adversário "da propagação das Luzes, da Liberdade de Imprensa - , o fautor e amante da estupidez... um inimigo da Constituição» (n. ${ }^{\circ} 3$, p. 34), de que é digno exemplo o artigo onde Rebelo de Carvalho, em tons irónicos e piadéticos, retrata a «Sociedade Literária e Científica de Balhelhas (Valhelhas)», símbolo da iletracia portuguesa, onde os seus sócios rejeitam «toda a denominação constitucional» (n. ${ }^{\circ} 10$, p. 156).

A estrutura interna de $O$ Censor Provinciano é, ao longo dos seus doze números, sensivelmente a mesma. Embora não haja artigos de fundo, existem, todavia, um conjunto de textos e rubricas várias. Mantendo sempre o mesmo formato e número de páginas, destaca-se, com alguma regularidade, a existência da secção "Cortes», onde se dá conta e faz a respectiva apreciação crítica dos acontecimentos que se passam no Congresso, "mas somente aqueles que se tornarem mais importantes pelos objectos ou pelas diversas opiniões sobre eles desenvolvidas» (n. ${ }^{\circ}$ 6, p. 89). Destacamos aqui a Lei do Recrutamento e as críticas ao trabalho desenvolvido pela Comissão de Instrução Pública.

Para além do espaço concedido à acção reformadora das Cortes, em vários artigos de o Censor Provinciano perpassa um grande tema: A Instrução Pública. Reflectindo sobre esta temática, reconhece-se que «nós carecemos doutra instrução, e em lugar de tantos doutores, que temos, precisamos de alguns homens doutos, que são coisas muito diferentes» (n. ${ }^{\circ}$ 6, p. 84). Daí as críticas ao excesso de bacharéis formados em Direito e à rejeição que as Cortes fizeram da proposta de reforma de instrução pública apresentada pelo professor da Faculdade de Filosofia, José Ferreira Santos do Vale.

Neste contexto e numa visão mais estreita é possível identificar, entre outras, as seguintes questões: escolas de primeiras letras, «sendo obrigado a ir nelas receber uma educação comum os filhos de todos os cidadãos» (n. ${ }^{\circ}$ 8, p. 114); 
seus professores e qualidades que devem apresentar; programas; escolas secundárias e escolas centrais.

No que se refere ao ensino superior, as atenções centram-se, fundamentalmente, na Universidade de Coimbra e no seu desfasamento da realidade. São fortes as críticas à Universidade «que conserva em seu ensino os mesmos livros, que o despotismo the indicava, para lhe servirem de apoio» (n. ${ }^{\circ}$ 7, p. 105); aos seus professores, métodos de ensino e conteúdos programáticos. Afastados da realidade, aqueles, em vez de publicarem coisas úteis, «todos os meses têm de reunir-se... para a importante resenha das faltas dos rapazes» (n. ${ }^{\circ}$ 1, p. 14), mas que se esforçam por explicar «todas as regras, vias e maneiras de entender o filosófico e profundo código Filipino» (n. ${ }^{\circ}$ 6, p. 94), para não se falar já das «informações» que os lentes de Coimbra dão, decidindo «no segredo dos destinos de muitos e muitos indivíduos», qual «monstruosidade colocada a par duma Constituição liberal» (n. ${ }^{\circ}$ 7, p. 106).

Críticas também para a Academia das Ciências que o Censor Provinciano vê, fundamentalmente, como uma instituição aristocrática, já que «seu título é de Ciências... e não de aristocratas, que para ela não têm dado mais do que o nome para aparecer no Almanaque» (n. ${ }^{\circ} 7$, p. 110).

Completa-se este periódico com algumas reflexões sobre a reforma da Companhia de Agricultura e Vinhos do Alto Douro, a independência do Brasil, chamando a D. Pedro «filho degenerado do Rei de Portugal» (n. ${ }^{\circ} 5$, p. 68) e ainda de um texto literário e alguma poesia, salientando-se, em especial, a dedicada a Manuel Fernandes Tomás, «o grande homem que tanto contribuiu para a nossa liberdade» (n. ${ }^{\circ}$ 2, p. 31). Daí a publicidade de uma subscrição a favor da família, em virtude do seu falecimento.

Termina este periódico com uma declaração do seu director, onde se lê: «O redactor deste papel tem, por agora, preenchido a sua tarefa... Ganhou, como ele estava certo de ganhar, a honrosa inimizade de todos os sapos do servilismo, de quem não quer outra coisa, e se dá por bem pago do pequeno trabalho, que teve em escrever estes poucos, mas liberais e independentes números...” (p. 190).

Bibliografia: Luís Reis Torgal, «A Imprensa estudantil em Coimbra e o radicalismo liberal vintista», O Liberalismo na Península Ibérica na primeira metade do século XX (Coordenação de Miriam Halpern Pereira, Maria de Fátima Sá e Melo Ferreira e João B. Serra), 2. vol., Lisboa, Sá da Costa Editora, 1982, p.p. 241-56; Luís Reis Torgal e Isabel Nobre Vargues, A revolução de 1820 e a instrução pública, Porto, Paisagem Editora, 1984, p.p. 275 e ss. 


\section{4 - O GENTENÁRIO DO MARQUÊS DE POMBAL}

\author{
Jornal comemorativo publicado pela Comissão \\ dos Estudantes de Coimbra \\ Coimbra, Imprensa da Universidade
}

1882
Cotas:

BN: -

BGUC: -

BPMP: -

BMC: GHC - $20 / 1$

Colaboradores: António Cândido, Alexandre da Conceição, Carlos Lobo de Ávila, Luís Osório, Augusto Rocha, Macedo Papança, A. Paçô-Vieira, Eduardo de Araújo, Francisco Gomes do Rego Feio, Manuel da Silva Gaio, Costa Macedo e J. Simões Dias

Formato: 22 x $29 \mathrm{~cm}$

Periodicidade: N. ${ }^{\circ}$ único

Preço: Não indica

Páginas: 21

\section{Conteúdo}

Inserido no contexto dos movimentos positivista e republicano e à semelhança do que havia já acontecido, em 1880, com a celebração do Tricentenário da morte de Camões, também, em 1882, mas com excepção dos estudantes teólogos (Cfr. A Evolução, n. ${ }^{\circ}$ 14, Coimbra, 27 de Fevereiro de 1882, p. 1), os estudantes de Coimbra celebraram, à sua maneira e nos dias 6, 7 e 8 de Maio, o Centenário da morte do Marquês de Pombal (Cfr. Idem, n. o 24, Coimbra, 15 de Maio de 1882, pp. 1 e 2).

De entre os eventos, fez-se a publicação do periódico $O$ Centenário do Marquês de Pombal que, segundo Carneiro da Silva, «não chegou a ser distribuído, por não se chegarem a imprimir o retrato do Marquês e uns fac-similes» (Jornais e revistas do distrito de Coimbra..., p. 37).

Trata-se de um pequeno jornal com textos em prosa e em verso, onde os diferentes colaboradores se preocupam, não só em recuperar a «memória» do grande estadista, mas sobretudo em apontá-lo como um símbolo de modernidade e anticlericalismo. Reproduzem-se pequenos excertos dos discursos proferidos, nos dias 6 e 7 de Maio, no Teatro Académico e no comício antijesuítico, por Carlos Lobo d’Ávila e A. Paçô-Vieira, respectivamente. 
A revivificação que se faz da imagem do Marquês de Pombal vem assim, no dizer de Fernando Catroga, «ao encontro das necessidades de legitimação histórica do combate laico» (A militância laica e a descristianização da morte em Portugal (1865-1911), vol. II, Coimbra, 1983, p. 928).

Bibliografia: Rui Bebiano, «O 1..$^{\circ}$ Centenário Pombalino (1882). Contributo para a sua compreensão histórica», Revista de História das Ideias, vol. IV, tomo II, Coimbra, 1982, pp. 381-428; Fernando Catroga, A militância laica e a descristianização da morte em Portugal (1865-1911), vol. II, Coimbra, 1983 (Edição policopiada). 


\section{5 - O GIDADÃO LITERATO}

Periódico de Política e Literatura

Lisboa, Nova Impressão da Viúva Neves e Filhos ${ }^{(1)}$

Janeiro 1821 - Abril 1821
Cotas:

BN: J.1334B.

BGUC: $10-5-26-4$

BPMP: RES-XIX-A-36(4)

BMC: GHC -3

Redactores: José Pinto Rebelo, Manuel Ferreira de Seabra e António Luís de Seabra

Formato: 13 x $20 \mathrm{~cm}$

Periodicidade: Mensal

Preço: Por trimestre $-1 \$ 800$ réis $\bullet$ Avulso - 400 réis

Páginas: 234

\section{Objectivo}

«Vai publicar-se com a brevidade possível o primeiro número de um periódico mensal intitulado: O Cidadão Literato...

Este periódico será dividido em duas partes: Na primeira terão lugar escritos tendentes ao nosso melhoramento político e propagação de princípios liberais: discursos, memórias, observações cujo fim seja o apontar abusos e vícios de legislação, de Administração de Fazenda, e Justiça, de Ensino Público, de Economia Política, etc.

... O nosso desejo é que a primeira parte deste periódico venha a ser, por assim dizer, um memorial para Cortes...

A segunda parte será destinada à Literatura propriamente dita. Na grande árvore dos conhecimentos humanos as belas letras são a flor, bem como as ciências o fruto...» (Prospecto).

\section{Conteúdo}

De acordo com os objectivos traçados, este jornal pretende, não só divulgar os ideais e os princípios do regime liberal, mas também contribuir para o seu

(1) Só o primeiro número é que foi impresso em Lisboa. Os outros, em Coimbra, na Imprensa da Universidade. 
aperfeiçoamento, através de um conjunto de reflexões e observações que se propõe levar a efeito e que, utilizando a sua própria linguagem, podem constituir «um memorial para as cortes», porque o tempo, agora, é de reformas.

E porque os tempos são outros, denunciam-se também algumas baixezas e práticas do Antigo Regime como, por exemplo, os autos de fé, no tempo de D. João V, e as «banalidades» de que os Fornos de Alcobaça e os Lagares da Ordem de Cristo ainda dispõem, usurpando assim avultados direitos aos povos.

Logo na Introdução, os responsáveis deste periódico, comungando na ideia, vinda já do iluminismo, de que a cultura tinha uma função emancipadora, reconhecem que o homem tem o direito de ser feliz, que a ignorância é uma fonte para os seus males e que o aperfeiçoamento do homem influi no aperfeiçoamento da sociedade e dos governos, pelo que «um povo ignorante jamais poderá ser um povo livre» (p. VI). Daí a aposta na ilustração do "cidadão", ajudandonos assim a compreender o título escolhido.

A estrutura deste periódico é a mesma, ao longo dos seus quatro números, quer quanto ao formato, quer ao número de páginas de cada um. Muitos dos artigos repartem-se por mais que um número.

Tendo em consideração os diferentes artigos, é possível identificar como temáticas principais as seguintes, onde se abordam questões como:

Instrução Pública: importância; os professores de primeiras letras; os programas das escolas primárias; as escolas de latim; novos saberes (sua importância e utilidade e necessidade); formação de um bom cidadão.

Justiça: necessidade de reformas: juízes, tribunais, processo criminal, instituição de jurados; projecto de regulamento para o processo civil de primeira instância de autoria de Vicente Nunes Cardoso, advogado em Chaves.

Política e Constitucionalismo: acontecimentos políticos na Europa; soberania popular; trabalhos das Cortes; reflexões sobre a Constituição Espanhola; o 102 problema do bicamaralismo; as bases da nossa Constituição; a eleição dos deputados.

Literatura Portuguesa: resumos históricos; Francisco José Freire e a importância da sua obra (publicam-se algumas epístolas); Bernardim Ribeiro; Cristovão Falcão.

Portugal e o Brasil: Que relações?

Completam este periódico algumas poesias e, para divertimento, pequenas anedotas. 


\section{6 • A GIVILIZAÇÃ̃o}

Coimbra, Imprensa da Universidade (1)

5 Dezembro 1869 - 15 Janeiro $1873^{(2)}$
Cotas:

BN: J.258B.; J.1072P.

BGUC: $10-9-13$

BPMP: $\mathrm{P} / \mathrm{B} / 6725$

BMC: GHC -4

Director: Custódio Veloso

Redactores: Carlos Brum da Silveira, José Gonçalves de Aguiar, António Cardoso Pinto de Vasconcelos e João Manuel Correia.

Colaboradores: Luís Guedes Coutinho Garrido, Francisco Rodrigues Gusmão, Joaquim Pedro Alves Crespo, Sebastião Pereira da Cunha, José Estevão Gonçalves, João da Silveira, Cardoso e Silva, Fernandes Costa e E. A. Vidal.

Formato: $23,3 \times 33 \mathrm{~cm}^{(3)}$

Periodicidade: Quinzenal

Preço: Assinatura mensal - 100 réis

Páginas: 288

\section{Objectivo}

"Convem que expliquemos rapidamente a inteligência da palavra civilização, pois, se bem que conhecida, importa fixar o seu sentido.

A civilização é aquela nobre tendência e exercício que tem por objecto geral o aperfeiçoamento do homem, quer se considere em si mesmo, no que diz respeito à sua parte material, intelectual e afectiva, quer se observe em sociedade, nas diversas condições em que possa encontrar-se...

Vejamos agora como se tem conduzido com a humanidade a civilização que procede do Cristianismo, ou da Igreja Católica.

Desde que nasce até que falece... o homem é o mais desventurado dos seres da natureza. Não é nosso propósito entrar agora nos pormenores dos cuidados especiais com que a Igreja rodeia o cristão desde o berço ao túmulo...

(1) A partir do n. 23 (inclusive) foi impresso no Porto, na Imprensa da Praça de Santa Teresa; do n. ${ }^{\circ} 26$ em diante, novamente em Coimbra, na Imprensa Literária.

(2) Não se publicou no mês de Outubro de 1870, durante todo o ano de 1871 e alguns meses de 1872.

(3) Do n.o 23 em diante, o formato é de $23,3 \times 32 \mathrm{~cm}$. 
Propomo-nos a considerar o homem em relação com os seus semelhantes... E qual é o segredo, a base, o fundamento, a regra e norma da civilização cristã, da política cristã, do procedimento da Igreja Católica para a civilização dos povos?... A todos e a cada um dos seus filhos diz a Igreja Católica, manda com o maior rigor, e impõe o santo e benéfico preceito ensinado por Jesus, o seu divino fundador: Amarás a teu próximo, como a ti mesmo... Aquele preceito natural e divino une a todos os homens com o estreito e doce laço do amor, que faz querer para todos o bem que se deseja para si mesmo, e aborrecer e afastar dos outros o mal que para si se abomina e de si se afasta» (A Civilização, Ano 1. ${ }^{\circ}$, Série $1^{\text {aa }}$, n. ${ }^{\circ}$ 18, Coimbra, 20 de Agosto de 1870, p. 137).

«Continuemos, pois, a nossa árdua tarefa. Toquemos constantemente a rebate nos arraiais católicos. Chamemos os povos à concórdia cristã, de que é sinal a palma do triunfo que está na dextra do Filho de Deus. Alumiemos as multidões com a luz da civilização religiosa, base de todo o progresso real da humanidade. Previnam-se os incautos; animem-se os tíbios; acordem-se os indiferentes. Saiamos a campo, não porque receiemos que triunfe o espírito do erro sobre os esplendores da verdade augusta que professamos, mas para que possamos acudir com o nosso tributo sincero a alguma vítima, que, talvez, nesta hora, esteja prestes a mergulhar-se no vórtice do materialismo torpe e grosseiro, que é o apanágio da nossa época... Assim temos obrado desde que descemos a esta arena, e cremos que no caminho percorrido não deixamos herança de desonra» (Idem, n. ${ }^{\circ}$ 23, Coimbra, 1 de Fevereiro de 1872, p. 178, col. 2).

\section{Conteúdo}

A Civilização é um jornal marcadamente católico e apostado em combater as ideias laicistas e materialistas do século XIX, na medida em que, segundo os seus responsáveis, o progresso da humanidade só é possível no contexto do cristianismo e do catolicismo, porque a igreja é «a mãe fecunda de todos os acontecimentos» (n. ${ }^{\circ}$ 1, p. 2, col. 1). Daí a saudação, logo no primeiro número, ao verbo divino e a afirmação de que «a luz que nos ilumina, a ciência que nos ilustra, a liberdade que nos enobrece, a fraternidade que nos une, provêm todas de uma fonte comum: descem do alto do Calvário» (n. ${ }^{\circ} 1$, p. 1, col. 1).

A colecção completa de $A$ Civilização engloba trinta e seis números, em duas séries. A primeira a terminar em 20 de Dezembro de 1870, com o n. 22 . De- 
pois de um interregno, não explicado, a segunda série começa em 1 de Fevereiro de 1872 , com a publicação do n. ${ }^{\circ}$ 23, vindo a concluir-se em 15 de Janeiro do ano seguinte.

Todos os números da $1^{\text {a }}$ e $2^{\text {a }}$ séries têm o mesmo número de páginas oito -, embora o formato da $2^{\text {a }}$ série seja, ligeiramente, mais pequeno, no sentido da altura.

A estrutura interna deste periódico é sensivelmente a mesma ao longo dos seus trinta e seis números. A primeira página é dominada por um artigo de fundo, que, em muitos casos, não ostenta qualquer título. Seguem-se, depois, um conjunto de textos e rubricas várias.

Nos artigos de $A$ Civilização perpassam dois grandes temas: um deles é o debate em torno do século. Fazem-se reflexões e tecem-se considerações críticas em relação aos novos tempos, onde se escondem os seguintes inimigos: «em religião...o paganismo. Em filosofia é o materialismo. Na história, o fatalismo. $\mathrm{Na}$ arte, o realismo. Em política... o despotismo». (n. ${ }^{\circ} 11$, p. 86, col. 2). Chamam-lhe tempo de «barbarie» (n. ${ }^{\circ}$ 32, p. 250, col. 2). Criticam-se os protestantes e os livres pensadores, porque têm sido «em todos os tempos o cancro moral da sociedade» (N.' 24, p. 183, col. 1), mas também os filósofos e os pensadores modernos que, de pouco a pouco, vão minando os incautos, a ordem e o bem público. Em vez de ensinarem ao povo os seus deveres, isto é, «essas obrigações santas que a moral prescreve» (n. ${ }^{\circ} 32$, p. 249, col. 2), preferem antes a exaltação dos direitos e dos poderes do homem. Daí as críticas ao socialismo e à Internacional, que apelidam de «associação abominável» (n. ${ }^{\circ}$ 26, p. 206, col. 1).

O outro traduz-se numa procura de afirmação do cristianismo e numa defesa do catolicismo, quer fazendo valer os seus princípios e doutrina, quer demonstrando a acção e importância da igreja e a autoridade do papa.

No entanto, questões há que, num desdobramento temático mais estreito, é possível identificar. Assim:

- As relações entre a Igreja e o Estado. A este propósito, Carlos Brum da Silveira defende que é importante que se estabeleça uma verdadeira doutrina que salvaguarde os interesses do Estado e da Igreja. Daí a proposta de duas sociedades distintas, mas não separadas. Em seu entender, «a forma deste contacto é o que se chama concordata; único meio de conciliar a liberdade política com a religiosa» (n. ${ }^{\circ} 22$, p. 172, col. 2). Protestos contra a ocupação do Vaticano por tropas italianas.

- Congregações religiosas. Interligada com aquela, uma outra temática é a das congregações religiosas. Fala-se da expoliação de que foram vítimas em 
Portugal. Recusando tecer qualquer comentário sobre este facto, o articulista reconhece, no entanto, que «nem a igreja, nem o estado lucraram com aquele golpe de uma política inconsiderada pelo menos» (n. ${ }^{\circ} 15$, p. 113, col. 1), para, logo de seguida, se defender a sua restituição,, porque daí «deve resultar grande utilidade para a religião que professamos, e por consequência para o país» (n. ${ }^{\circ}$ 17, p. 129, col. 1). Daí o convite que, no artigo intitulado «Ao Episcopado» (Cfr. n. ${ }^{\circ}$ 30, p. 233), é dirigido aos bispos e altos dignatários da igreja, no sentido de efectuarem as diligências necessárias junto do poder político. Diga-se ainda que esta temática é objecto de um estudo de carácter histórico, da responsabilidade de Custódio Veloso, repartido por vários números, com o título de «As ordens monásticas».

- Educação religiosa católica. Constatando existir na sociedade um brado de «abaixo a religião» (n. ${ }^{\circ}$ 29, p. 226, col. 2) e uma certa indiferença, religiosa e reconhecendo-se, também, que as questões não são fáceis nem se encontram desligadas, defende-se uma educação de cariz religioso, mas de cunho acentuadamente católico. É este o sentido do artigo «Educação do coração e da inteligência». Em matéria de educação, este artigo é completado por outros, nomeadamente, os intitulados «A leitura como elemento da educação» e «Influência da religião na educação", repartidos por vários números. Se neste se reflecte sobre a importância social da educação, se alude à relação entre educação e sociedade, se defende uma aliança entre religião e ciência e se advoga uma educação católica que «estabeleça a união tão necessária entre a fé dos antigos tempos e os novos elementos dos nossos dias» (n. ${ }^{\circ}$ 20, p. 159, col. 2), no outro tecem-se considerações, que são «filhas da experiência» (n. ${ }^{\circ}$ 16, p. 126, col. 1), sobre os diversos tipos de leitura (séria e recreativa), para se concluir que a prática deste exercício deve ser vigiada, inspirando-se, desde cedo, o gosto pelas leituras instrutivas e sérias e controlando as recreativas. Deve afastar-se todo o tipo de literatura romântica, porque «nem convicções nem dignidade 106 apresenta» (n.o 20, p. 158, col. 2). Defende-se, também, uma imprensa católica, que há-de ajudar a igreja na sua missão.

- O problema do suicídio. É com uma educação religiosa-católica que outras questões podem ser evitadas ou melhor solucionadas. Uma delas é o suicídio que é definido, não só como um crime contra a natureza, mas sobretudo «um crime contra Deus» (n. ${ }^{\circ} 28$, p. 218, col. 1).

- Liberdade, autoridade e tolerância. Procura-se, numa série de artigos, mostrar as relações verdadeiras entre a liberdade e autoridade, para se chegar à 
conclusão de que não é aos católicos que se podem atribuir os epítetos de retrógrados e intolerantes, mas sim aos que os acusam. Estão neste caso os protestantes que, para o efeito, evocam o tribunal da inquisição. Os católicos defendem-se dizendo que a inquisição foi «um bom tribunal..., pois procurava o bem-estar da sociedade e a felicidade dos povos» (n. ${ }^{\circ}$ 26, p. 203, col. 1), enquanto o protestantismo tem carácter revolucionário, como o demonstram os exemplos da Alemanha e da Suíça. (Cfr. O artigo intitulado «O acapamento da perseguição na Suiça», in, n. o 30, de 15 de Maio de 1872). Depois do artigo, uma oração, onde se pede, «em particular por nossos irmãos da Suiça, vítimas duma tirânica opressão que ameaça Roma e o mundo todo» (Idem, p. 240, col. 1).

- Questões de História. Num conjunto de ensaios reflecte-se sobre o método em História (Heródoto e Vico); fala-se da história de Roma (a jurisprudência romana, Catão e Cipião Africano, a influência grega).

- Questões de literatura: Reflecte-se sobre a relação entre sociedade e literatura; alude-se um pouco à literatura portuguesa contemporânea (Almeida Garrett e sua obra); numa série de artigos, fala-se de literatura francesa; nomeadamente, de Prosper Merimée. Faz-se, também, uma apreciação da obra $O$ Sangue de Germânico.

De referir ainda um conjunto vasto de informações sobre o Concílio do Vaticano, as Congregações Gerais e o andamento dos trabalhos bem como a publicação de documentos vários relacionados com o evento e ainda outros emanados da Santa Sé.

De salientar, neste periódico, a existência das seguintes secções, no contexto da 1'a Série: "Mosaico Religioso", onde se dão notícias várias sobre religião; "Mosaico Literário», com informações sobre livros, revistas, poemas, romances, etc.; na 2 a série: "Secção Literária», onde se fala da Língua Portuguesa e sua relação com a nossa história, reflexões sobre Literatura, apreciação de obras e transcrição de poesias, mas com tonalidade marcadamente católica; «Secção Noticiosa», com notícias do país e do estrangeiro. Já perto do último número, a secção «Revistas de Jornais», que é um espaço onde se registam os principais artigos publicados na imprensa católica do nosso país.

Completa-se este periódico com algumas máximas e pensamentos, apreciações de obras dadas à estampa e ainda a divulgação de conhecimentos úteis. 
- CLARIM DAS RUAS

Semanário Republicano Académico

Coimbra, Tip. Operária

2 Dezembro 1897.
Cotas:

BN: J.781//7A ; J.998A

BGUC: B-38-57

BPMP: -

BMC: GHC -21/1

Editor: José Maria dos Santos Nazaré

Formato: $31,5 \times 45 \mathrm{~cm}$

Periodicidade: Semanal

Preço: Trimestre -350 réis

Páginas: 4

\section{Objectivo}

«Saibam todos os que têm olhos para ver e cérebro para pensar que cá estamos, que este semanário, continuação do Portugal por nós redigido nada tem de comum com o Portugal que foi orgão do Grupo Republicano Académico...

O Clarim das Ruas será sempre o primeiro a dar o sinal de guerra, porque é escrito por penas novas, cheias de vida e que na cadeia serão os mesmos homens que em liberdade, que, presos embora, não se julgam feridos nem desanimados senão quando um pedaço de chumbo lhe faça gelar as extremidades e lhe diga vai para a refeição comum...

Queremos ir na vanguarda, queremos ser os vedetas perdidos que mostremos ao país que ser estudante e ser republicano revolucionário não é só escrever que a Revolução urge, que estamos em um estado desesperado para o qual a medicina política não tem nada a receitar, ou a cirurgia da evolução política operação alguma a fazer.

Ser estudante é indicar ao Povo, ao País, à Humanidade qual o caminho

108 que deve seguir, orientá-lo, mostrar-lhe os atalhos que deve evitar, as encruzilhadas de que deve fugir.

Ser republicano é guerrear pela pena e pelo facto o actual regime de dissolução e venalidade.

Ser revolucionário é pegar numa escopeta e ir com ela na vanguarda do exército do Povo revolucionado, mostrar como se morre, com se guerreia o existente.

(1) Até ao n. ${ }^{\circ} 4$ teve o título de Portugal. 
Ser estudante republicano-revolucionário é tudo isto, é o não temer a morte, é o ter desdém pela vida.

O Clarim das Ruas, garanti-mo-lo, há-de saber cumprir a missão que se impôs, há-de saber mostrar que a intransigência do espírito académico revolucionário vai até ao ponto de se não mandar um folhetim para um jornal monárquico, um protesto republicano para o jornal de todos os partidos, para o Século, para esse jornal que o Grupo Republicano de Estudos Sociais excomungou, que o actual Directório votou à execração pública...

É por isso que o Clarim das Ruas há-de ter muitos inimigos, porque se não roja aos pés de ninguém...

Não somos orgão de qualquer dos partidos que dividem o Partido Republicano, somos orgão da nossa consciência, do nosso modo de pensar.

Quando aos chefes parecer que levamos orientação errada é dizer-no-lo com franqueza, sem atavios de linguagem, pesaremos as razões e sem ser num automatismo repugnante, numa passividade obediente, cederemos, mas cederemos, quando as razões nos mostrem que o devemos fazer, quando as circunstâncias o exijam...

Quem ler $O$ Clarim deve convencer-se imediatamente que ele é escrito por quem não tem ração à mesa da monarquia, por quem espera ter colocação só à custa do seu trabalho, do seu estudo.

E mais nada; aí fica o nosso modo de ver as coisas e o mundo» (Clarim das Ruas, n. ${ }^{\circ}$ 4, Coimbra, 2 de Dezembro de 1897, p. 1).

\section{Conteúdo}

Para além do artigo de fundo que define as linhas programáticas do próprio jornal, dois textos mais dominam este pequeno periódico. O primeiro, que é uma transcrição de um artigo do jornal Odemirense, diz respeito à problemática da centralização e descentralização política, evidenciando as vantagens desta sobre aquela, na medida em que o «regime centralista foi sempre incompatível com a liberdade e com a boa administração dos negócios públicos» (Idem, p. 2); no segundo texto, com o título de «Voltando à carga» defende-se que a melhor estratégia para o triunfo da República é já o caminho da Revolução.

Completam o jornal um conjunto muito variado e diverso de notícias que vão desde o anúncio de novas publicações, factos académicos até falecimentos e assaltos. A última página é reservada à publicidade. 


\section{8 - COIMBRA EM FRALDA}

\author{
Coimbra, Imprensa Comercial \\ 1 Junho 1883 - 1 Julho 1883
}

Director: Solano de Abreu

Editor: José Correia de Almeida Júnior

Colaboradores: Acácio Guimarães, A. Pinto da Rocha, Afonso Vargas, António Navarro, Costa Santos, Ezequiel David, E. Costa Macedo, Eduardo do Vale, J. Serras Conceição, J. Lorjó Tavares, M. Oliveira Ramos, Silvestre Falcão, Santos Melo, Trindade Coelho e Júlio César Machado.

Formato: 23,5 x 32,5 cm

Periodicidade: Quinzenal

Preço: Trimestre: 300 réis • Avulso: 60 réis

Páginas: 8

\section{Cotas:}

BN: J.3578//36B; J.2460//11V.

BGUC: $10-5-20$

BPMP: -

BMC: GHC -20/10

\section{Objectivo}

«Somos boas pessoas, vimos de perto e queremos pouco. Se não temos precisamente o aspecto de um comendador, a autoridade do Sr. Martins de Carvalho (Director de $O$ Conimbricense), a eloquência do Sr. Sousa dos Vidros, temos contudo a gravidade, que dá a altura das circunstâncias. Se não trazemos diplomas oficiais de apresentação, enflora-nos o casaco uma rosa Príncipe Negro, de pétalas aveludadas, rica de aromas; e nos lábios o rir franco, a gargalhada sonora, que acompanha o ridículo, que por aí passeia muito à vontade, muito sem cerimónia. De resto, repetimos, boas pessoas, que não têm ódios íntimos às instituições, e que não se propõem a apear ídolos, bezerros de ouro, erguidos por aí com muito descaro...

Queremos pouco-rir e dar piparotes nas coisas e nas pessoas, elevadas por aí em pedestais de barro, e que têm a adoração cega dos fanáticos» (Coimbra em Fralda, n. ${ }^{\circ}$ 1, 1 de Junho de 1883, p. 8, cols. 2 e 3).

\section{Conteúdo}

Ao longo dos três números, o jornal mantém uma estrutura estável. De acordo com os objectivos traçados, este jornal denuncia, em artigos vários, o que na 
sociedade é balofo e convencional. Perfilhando os cânones da escola realista-naturalista, os colaboradores desta publicação apostam num processo de índole demolidora. Daí o ataque às falsas reputações e às falsas virtudes. É o caso, entre outros, do artigo «Scenas Vulgares» da autoria de alguém que utilizou, propositadamente, o pseudónimo de Padre Filho Espírito Santo, onde se desmascaram casos de delegados, deputados, engenheiros, médicos e militares que, passando por Coimbra, não deixam de enviar um bilhetinho à engomadeira Emília, com quem haviam partilhado amores, em tempos de estudante, dizendo-lhe, agora, que «estava cá, muito de fugida, que fosse vê-lo ao hotel, esperava-a à noite» (n. ${ }^{\circ} 1$, p. 3, col. 2).

Também Solano de Abreu no texto «As Soirées da Baixa» denuncia o oportunismo de certos comerciantes, como o Machado (comerciante na Baixa de Coimbra), que sendo, em outros tempos, contra festas, permitia, agora, que sua filha as fizesse e «convidasse quem quizesse», porque «queria casar a filha (e) à noite viriam estudantes, um bacharel para «genro era outra coisa, e depois boas fortunas lá pela terra, porque quem é pobre não os manda para cá, raciocinava» (Idem, p. 4, col. 2).

Existe também a preocupação em corporizar e divulgar ideias novas que são indispensáveis às tarefas da modernidade. É o que, por exemplo, Serras da Conceição faz em dois artigos que intitulou de «Estudos de Crítica. O Naturalismo», onde escreveu: «O naturalismo é actualmente a única fórmula da arte capaz de satisfazer as necessidades estéticas da sociedade moderna», porque «o romantismo é uma fórmula inane e vazia, incapaz de satisfazer os espíritos e o gosto moderno, educados no estudo da realidade, na observação da vida e na interrogação da natureza» (Idem, n. ${ }^{\circ}$ 2, p. 4, col. 2).

Em textos diversos põe-se a claro uma mundividência do social, retratando-se ambientes sociais e culturais de Lisboa e Coimbra.

A completar o jornal a existência ainda de outras matérias, nomeadamente, rubricas que incluem: poemas, crónicas de acontecimentos políticos e notícias de índole diversa.

Bibliografia: Trindade Coelho, In Illo Tempore, Col. Europa-América, n. 287, Mem Martins, s.d., p.p. 74 e ss. 


\section{9・O GOLIBRI}

Folha Semanal, jocosa, científica e literária

Coimbra, Tip. Minerva Central (1)

2 Abril 1896 - 15 Maio 1896

\section{Cotas:}

BN: J.2456//19V

BGUC: -

BPMP: $\mathrm{P} / \mathrm{A} / 1331$

BMC: GHC-4

Administrador: Boaventura Aguiar

Redactor: A. G. da Cunha

Formato(s): $20 \times 26,5 \mathrm{~cm} ; 20 \times 27 \mathrm{~cm}$;

$20 \times 28 \mathrm{~cm} ; 16 \times 24 \mathrm{~cm}$

Periodicidade: Semanal

Preço: 50 réis por mês

Páginas: 4

\section{Objectivo}

«Iniciamos em Fevereiro a publicação de um jornal manuscrito com o modesto título de Echo da Curiosidade chegando-se até a distribuir alguns exemplares... mas sobreviveram naquela ocasião dificuldades tão invencíveis que nos foi de todo impossível continuar a sua publicação. Resolvemos então esperar mais algum tempo e eis-nos agora pondo em prática a nossa ideia começando a publicação deste outro jornal também manuscrito intitulado O Colibri.

A índole do nosso jornal é idêntica à do extinto Echo da Curiosidade, isto é, terá artigos jocosos, científicos, literários, poesias, anedotas e no fim tudo quanto possa simultaneamente ser útil, agradável e instrutivo...» (O Colibri, n. ${ }^{\circ} 1$, p. 1).

«Primitivamente manuscrito, tem passado por todos os graus de elevação sendo sucessivamente copiografado, litografado, até que, de agora em diante, satisfazendo as suas aspirações, sairá impresso... Sem outra ambição do que a de agradar aos nossos leitores sentimos não poder publicar $O$ Colibri mais do que duas vezes por mês...» (Idem, n. ${ }^{\circ}$ 5, Coimbra, 15 de Maio de 1896, p. 1. col. 1).

(1) Refere-se apenas ao n. ${ }^{\circ} 5$, que é o único número que foi impresso. 


\section{Conteúdo}

Trata-se de um pequeno jornal, sem grande interesse, cuja finalidade principal era ajudar a passar o tempo e fazer rir, a par de uma leve instrução.

Inicialmente copiografado, depois litografado e por último impresso, fez com que o formato não fosse sempre o mesmo, apesar de o número de páginas permanecer igual em todos os números.

Embora, em alguns números, conste, na primeira página, um ou outro pequeno texto como, por exemplo: «A Guerra de Cuba» e «A morte do Hilário», o que, em termos estruturais, caracteriza, verdadeiramente, este pequeno periódico é a existência de três secções distintas: uma secção literária, com romances, poesia e contos; uma secção científica, onde se publica um texto sobre «A arte fotográfica» e uma secção recreativa, onde se inserem «diversos géneros de passatempo, os quais constituirão um agradável deleite para os nossos leitores. Com esse fim publicaremos aqui charadas, enigmas, perguntas enigmáticas, etc., etc» (n. ${ }^{\circ} 1$, p. 2).

Tratando-se de um jornal de entretenimento, é de salientar o tom humorístico de que por vezes se reveste, mesmo quando em causa estão outros objectivos. Um exemplo é o que se passa com a mudança de cor, no terceiro número. Enquanto os dois primeiros são redigidos em tons de azul, o terceiro é escrito a preto. Os seus redactores justificam a mudança, porque «morreu-lhe sua avó torta», maneira extraordinariamente habilidosa e bem humorada de solicitar a todos os seus assinantes o respectivo pagamento, porque, dizem, «tem de fazer várias despesas com o luto» (n. ${ }^{\circ}$ 3, p. 3).

Já para rir e com o título de «Epitáfio», lê-se: «Aqui jaz eternamente/ um bombeiro dos d'arromba/Mesmo na cama, doente,/De contínuo dava à bomba» (Idem, p. 2). 


\section{0 - CORREIO DA UNIVERSIDADE}

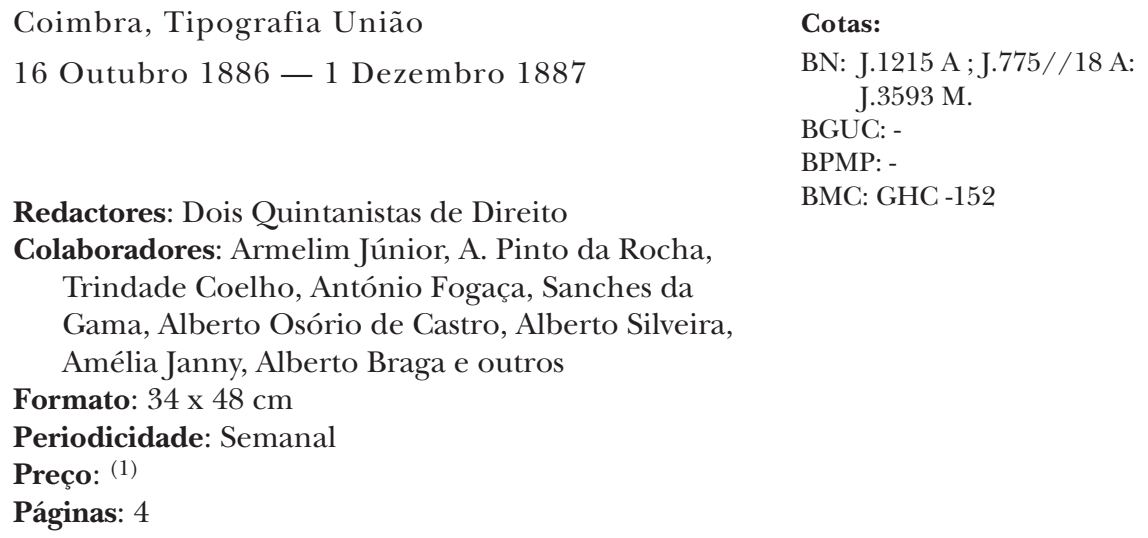

Redactores: Dois Quintanistas de Direito BN: J.1215 A ; J.775//18 A: BGUC: J.3593 M.

\section{Objectivo}

«Temos a honra de apresentar hoje ao público o primeiro número do Correio da Universidade...

O Correio da Universidade será principalmente um jornal noticioso, que há- -de transmitir semanalmente às diferentes terras do país os factos ordinários e extraordinários, que se passarem dentro da Universidade e no seio da Academia, acompanhando-os de uma apreciação perfeitamente independente, perfeitamente imparcial...

O nosso semanário ocupar-se-á também da Academia considerada como entidade colectiva, e desejará muito ver despertar e permanecer esse amor da pátria, que produziu os formidáveis batalhões académicos e esse entusiasmo cívico, iminentemente civilizador, que ainda há pouco produziu o tricentenário

114 de Camões.

Como se vê, referimo-nos principalmente à Academia da Universidade, mas compreendemos também os estudantes do Liceu e Seminário.

(1) 1. É Época

Trimestre - 480 reis (sem estampilha) - 520 reis (com estampilha)

2. ${ }^{\text {a }}$ Época

Trimestre - 440 reis - Avulso 40 reis 
As nossas vistas porém, não param só aqui; ainda este ano procuraremos organizar os nossos trabalhos de forma tal, que possamos dar aqui notícia dos principais estabelecimentos científicos do país e do seu movimento académico» (Correio da Universidade, 1. ${ }^{\circ}$ Ano, n. ${ }^{\circ} 1$, Coimbra, 16 de Outubro de 1886, p. 1, cols. 1 e 2).

\section{Conteúdo}

Ao contrário da maior parte dos periódicos estudantis, que não vão além dos fatídicos três meses, Correio da Universidade teve uma vida maior e conheceu, inclusivamente, duas épocas, embora a segunda bastante efémera. Saiu o seu primeiro número em 16 de Outubro de 1886, vindo a interromper a sua publicação com o n. ${ }^{\circ}$ 20, em 8 de Março de 1887, terminando assim a sua 1. ${ }^{\text {a }}$ Época. Reapareceu, depois, em 17 de Novembro do mesmo ano ${ }^{(1)} \mathrm{com}$ a indicação do Ano II e uma nova numeração para terminar com o n. ${ }^{\circ}$ 3, em 1 de Dezembro.

Para lá da informação, fazemos esta anotação, na medida em que ela marca uma diferença de posição da redacção do jornal relativamente à 1. ${ }^{\mathrm{a}}$ época. Os responsáveis do jornal são, agora, muito mais críticos e contundentes para com a instituição universitária. Logo no primeiro número da 2. época, em palavras dirigidas à Academia, escrevem: «Simplesmente duas palavras sobre o novo carácter que vamos dar ao Correio da Universidade.

Em todos os números passados, desde a primeira até à última coluna, ressalta uma timidez na apreciação dos factos universitários, que a nosso ver muito concorreu para os resultados finais do ano passado, resultados, que a academia inteira deve ponderar para seu procedimento futuro.

A academia foi mais uma vez vítima das cobardes naifas universitárias. A reacção é necessária e indispensável, necessária e indispensável a bem da justiça, necessária e indispensável a bem do ensino, necessária e indispensável a bem da ciência. Vamos reagir com toda a energia, mas seriamente, dignamente, den-

(1) Segundo Armando Carneiro da Silva, o jornal reapareceu em 12 de Novembro de 1887 (Ob. cit., p. 49). Realmente, é esta a data que figura no cabeçalho do periódico. Porém, no número seguinte, aparece uma «errata que nos diz: «O número anterior do Correio da Universidade saiu com a data de 12 de Novembro, quando devia sair com a data de 17 (Correio da Universidade, Ano II, n. ${ }^{\circ}$ 2, Coimbra, 24 de Novembro de 1887, p. 1, col. 3). 
tro e só dentro da esfera da lei» (Correio da Universidade, Ano II, n. ${ }^{\circ}$ 1, Coimbra, 17 de Novembro de 1887, p. 1, col. 1).

De uma maneira geral, a estrutura interna de Correio da Universidade é, ao longo dos seus vinte e três números, muito idêntica. Em princípio, a primeira página é dominada por um ou dois artigos, seguindo-se, depois, um conjunto de textos e matérias várias, para as últimas serem preenchidas, normalmente, com uma «secção literária», uma «secção noticiosa» e publicidade e, em alguns números, com informações dos principais estabelecimentos científicos do país (Universidade, Academias Politécnicas, Escolas Médico-Cirúrgicas, Liceus e Seminários), seu movimento académico e livros adoptados.

Nos artigos de Correio da Universidade perpassam dois grandes temas, que, apesar da sua interligação, nós aqui separamos: o primeiro tem a ver com o ensino superior e a Universidade, nomeadamente a sua Faculdade de Direito, até porque os redactores deste jornal são «Dois quintanistas de Direito»; o outro diz respeito à Academia, a quem se pede colaboração, porque «as colunas do... jornal estão... à disposição de toda a Academia...» (Idem, p. 1, col. 2).

Num desdobramento temático mais estreito é possível identificar as seguintes questões:

- O monopólio do ensino universitário por parte da Universidade de Coimbra;

- Projecto de reforma para o ensino superior: a proposta apresentada na Câmara dos Deputados pelo Dr. Alfredo da Rocha Peixoto;

- Foro Académico: ao longo de vários números, faz-se um historial deste «desaforo universitário» (Idem, n. ${ }^{\circ}$ 6, p. 1, col. 2);

- Problemas da Universidade: o funcionamento da biblioteca, os regulamentos internos, as relações professor-aluno, a política do Reitor;

- Faculdade de Direito: reforma, a importância da disciplina de Medicina Legal, reflexões sobre sistema de ensino e avaliação, os exames do 5. ${ }^{\circ}$ Ano jurídico, em 1886-87 e o modo como algumas disciplinas foram leccionadas, o vencimento dos professores e o seu trabalho;

- Faculdade de Teologia: contributo para a sua história (a condenação em Roma da Memória apresentada pelo Dr. Damásio Jacinto Fragoso ao Conselho Superior da Instrução Pública, críticas à retractação do mesmo professor);

- Faculdade de Matemática: reforma (vencimento do professorado, trabalhos e exercícios práticos); 
- A Praxe: modalidades de praxe, a capa e a batina

- Conflitos académicos e a posição das autoridades

- Ambiente cultural: o quotidiano estudantil, imprensa estudantil-problemas.

Para além de textos em prosa, alguma poesia e a apreciação de novas publicações, em artigos vários reflecte-se ainda sobre assuntos diversos, nomeadamente: a mania do emprego público, a carreira da magistratura, instrução pública, tribunais administrativos, livre-arbítrio e determinismo.

Completam o periódico, para além dos habituais folhetins, uma «secção noticiosa» com informações múltiplas e diversas, quer do país, quer mesmo do estrangeiro. 


\section{1・ A GRISÁLIDA}

Jornal de Literatura ${ }^{(1)}$

Coimbra, Imprensa da Universidade (2)

31 Outubro 1863 - Junho 1864

Administrador: Duarte de Vasconcelos

Redactor: Teófilo Braga e J. Simões Dias

Colaboradores: A. G. da Silva Sanches, Guimarães Fonseca, Manuel S. Alegre, J. Jacinto Nunes, Augusto Ferreira, A. Eduardo de Moura, Cândido Pereira de Figueiredo, Teresa Isaura, A. J. Ribeiro de Campos, Henriqueta Elisa, J. Ferraz de Carvalho, Amélia Janny, G. B. Garcia Pereira, Sousa Viterbo

Formato: 19,5 x 27,5 cm

Periodicidade: Semanal (3)

Preço: Coimbra-semestre - 720 réis

Províncias -800 réis

Páginas: $162+8$ de «Brinde aos assinantes da Crisálida»
Cotas:

BN: J.147//5B;P.P.12061V.

BGUC: 10-7-14-12; 10-9-7

BPMP: P-B-2165 [8]

BMC: GHC $-20 / 1$

\section{Objectivo}

«Desde o momento solene, em que a imensidade ouviu da boca do Eterno o maravilhoso fiat lux, e a vida começou a estremecer no gigante, como no verme, a luz da ciência rebrilhou nos horizontes do Eden, e continuou cada vez mais intensa nos horizontes da vida: até que um homem, semi-deus da luz Guttemberg - repetiu o fiat, e para cada extremidade do universo atirou as estrelas da ciência - descobriu a Imprensa!

É belo ver como desde então surdem novas e variadas cruzadas a empenharem-se com reiterada força na grande liça, em que se debatem os dois fortíssimos atletas - a luz e a ignorância, o progresso e o obscurantismo...

(1) O último n. ${ }^{\circ}$ tem como subtítulo: Semanário, Científico e Literário (Académico).

(2) $\mathrm{O}$ n. ${ }^{\circ} 20$ foi impresso na Imprensa do Comércio de Coimbra.

(3) A redacção diz-nos que a irregularidade na saída do jornal deve-se «ao mau estado de saúde do seu administrador» (n. ${ }^{\circ} 12$, p. 98, col. 2). 
Sirvamos nós a instrução popular, como Antigono ao Deus dos povos sem o pacto accipiendi mercedem. Não seja justo somente o que nos convem.

Também o povo tem direito à luz da ciência, como ao Sol que Deus fez para todos. A escola egoísta surgiu com Hobbes, e morreu: a perfeita confraternidade nasceu com Cristo, e viverá...

Como a abelha embrionária na célula, demore a Crisálida na seda, que vai tecendo, para cobrir juvenis espíritos...

Seja o jornal o filho benquisto de Guttemberg. Seja ele o termómetro do calor científico de cada dia, até que o livro possa comprovar ao povo a exactidão do seu aumento gradual.

O jornal é o oráculo da ciência que não procura a biblioteca para falar do presente e providenciar para o futuro: de cada uma casa faz ele um templo: de cada boca um intérprete: de cada homem um amigo: e de cada família um auditório de admiradores...

Sentemo-nos pois à mesa do festim literário e daqui trabalhemos todos neste edifício da literatura, para onde se arrastam os grandes materiais da ciência europeia... Somos jovens em forças, mas velhos no desejar o nivelamento social pela instrucção» (A Crisálida, n. ${ }^{\circ}$ 1, 31 de Outubro de 1863, p. 1).

\section{Conteúdo}

Como os seus responsáveis referem, A Crisálida pretende divulgar ciência e cultura, no sentido de servir a instrução popular, com vista a um melhor nivelamento social. Anote-se, também, o sentido de filantropia desta publicação, em virtude da protecção, na doença, para com o seu administrador, F. A. Duarte de Vasconcelos. Por isso, este lhe agradece, dizendo: «Deus vos cubra a todos de bençãos no céu, como vós cobristes de consolação o meu leito de agonia» (n. ${ }^{\circ}$ 12, p. 95, col. 2).

Quanto à sua estrutura diremos que se o número de páginas é igual em todos os números -8 páginas - excepto em o n. ${ }^{\circ} 6$, com 10 , já o mesmo não acontece relativamente ao formato que varia. Salientamos, desde já, que entre os n. ${ }^{\text {os }} 5$ e 6 , a direcção do jornal distribuiu um brinde aos leitores, espécie de um número especial, igualmente com 8 páginas, intitulado «Brado aos Portugueses», evocando o dia da Restauração.

Ao longo dos seus vinte números, a estrutura interna é sensivelmente a mesma. De uma maneira geral, a primeira página apresenta um artigo de maior fôlego, ao que se seguem textos e rubricas várias. 
Reconhecendo-se que cada época tem as suas características próprias, em artigos vários reflecte-se e louva-se a excelência do século XIX, na medida em que nele e com ele se afirmou, não só o progresso individual do homem, mas também o seu desenvolvimento social.

Em termos políticos, critica-se a monarquia absoluta e a teoria do direito divino dos reis, na medida em que «os reis eram tudo, os povos eram nada" (n. ${ }^{\circ}$, p. 5, col. 2). Louva-se o regime liberal, que predomina em quase toda a Europa, para, logo de seguida, se anotar que «é sublime ver como o homem se tem elevado em dignidade moral» (Idem).

No desejo de ilustrar e instruir, reflecte-se sobre questões como: o trabalho, que é «um símbolo da dignidade do homem» (n. ${ }^{\circ}$ 1, p. 3, col. 2); problemas de filosofia: o sentimento, a felicidade, o progresso, a igualdade entre os homens e a imortalidade da alma.

Questões de economia. Fala-se de agricultura e indústria: defende-se o associativismo e a ajuda mútua; fala-se da importância dos caminhos de ferro no desenvolvimento económico e da Exposição Industrial do Porto.

Em «Distracções/Divagações», procuram-se explicações para determinados acontecimentos e realidades: a reforma de Lutero; os partidos políticos e a sua importância no contexto das nações; religião e liberdade de culto.

No âmbito cultural de referir ainda o texto intitulado «Uma visita ao Mosteiro do Lorvão".

Como jornal literário que é, em A Crisálida inscrevem-se textos em prosa e verso. No domínio do conto e do romance salientamos «Contos da Tia Cecília», «A virtude de Leonor» $\mathrm{e}$ «Um noivado de sangue». Relativamente à poesia e para além de outras, referimos o «Hino. A sua Majestade Imperial a Duquesa de Bragança» e «Hino. Da ponte do Sarzedo», referente à inauguração desta mesma ponte, em 1858, perto de Arganil. A existência de um pequeno artigo sobre a poesia mística portuguesa e Frei Agostinho da Cruz.

Dão-se também notícias da visita da Família Real a Coimbra. No âmbito de uma história da Academia alude-se a uma petição dirigida aos deputados, no sentido de se obter um perdão de acto.

Completa-se este periódico com a secção permanente de "Crónica», onde se dão notícias e se relatam acontecimentos, não só de Coimbra e da Academia, mas também de terras vizinhas como Soure, de quem o cronista diz que «é uma das melhores vilas que rodeiam Coimbra, mas não há formosa sem senão. O desta é a sua mal entendida política» (n. ${ }^{\circ} 18$, p. 144, col. 2). 


\section{2・ A CRÍTICA}

Ciência, Literatura e Crítica

Coimbra, Tip. Operária

Janeiro 1888 - Março 1888
Cotas:

BN: J.3142//19 B.; J.3578//45B.

BGUC: $10-5$ - 21- 10

BPMP: P/B/4392(7)

BMC: GHC $-20 / 1$

Redactor: Lomelino de Freitas, Armelim Júnior

Colaboradores: Júlio de Faria, Camilo Pessanha, Pinto da Rocha, Bernardo Lucas

Formato: $21,5 \times 31 \mathrm{~cm}$

Periodicidade: Mensal

Preço: Assinatura - mês -150 réis $\bullet$ Avulso -40 réis

Páginas: $4-8$

\section{Objectivo}

"Corremos para uma vida melhor de trabalho honesto e lícito, enfadados da monotonia deste meio coimbrão, e do acanhado deste horizonte intelectual insofrível ao menos exigente.

A vista de quadros sombrios de misérias, expostos abundosamente nesta grande feira de ciência, repugna tanto e tanto às consciências calmas, que não provocará de certo o assombro, mais um brado de indignação, junto ao clamor de gerações que já lá dobram o portal do túmulo, ou transpõem o limiar da vida pública.

Longe, contudo, de trilhar a senda rotineira da maledicência, sempre pérfida e tediosa, empunharemos como arma de combate, a férula da crítica sã e admissível. Traçando esta linha de comportamento, depomos, altanadamente, a máscara do anónimo, porque julgamos exercer um direito. A liberdade de manifestação de pensamento, anelada outrora pelos luminares da ciência, mal despontando de entre as brumas da ignorância primeva, é hoje uma verdade tangível que exultamos de fruir.

Assim iremos ao fim proposto sem desfalecimentos de medo... É uma obrigação não ocultar a verdade com eufemismos e perifrases, e expo-la-emos em toda a sua desnudez, plácida e serenamente - porque é placidez e serenidade que advem à consciência, com a observância precisa do dever. 
Prevemos dificuldades em seguir tal derrota, mas não nos importamos que o caminho se encrespe de abrolhos, quando o horizonte atrai de proveitos. Não trepidamos em face duma hidra-oposição ou duma censura soez que não valha o almasso da réplica...

Corremos risco de desagradar aos entusiastas da retórica, por não sabermos bordar frases nem rendilhar períodos. Lembramos... que a única e boa expressão da verdade, é a linguagem lacónica, a recta que leva ao ponto desejado...

Reiteramos estes propósitos para que calem no ânimo dos mais embebidos nos prejuízos e crendices dum meio embotado.

Usamos da crítica, como dum exercício útil e moral, como dum trabalho lícito e elevado. Criticando, trabalhamos para nós e para os outros. Para nós, porque corrigimos os erros duma orientação bastarda; para os outros, porque os despimos de vaidades enganosas que aviltam, ou lhes aconselhamos o esforço e a perseverança, como únicas alavancas capazes de levantar a inteligência.

Todavia não pára aqui a utilidade da crítica. Divisa-se nela muito mais - a faculdade dominante do século e o mais profícuo deporatório da sociedade hodierna» (A Crítica, n. ${ }^{\circ}$ 1, Janeiro de 1888, p. 1).

\section{Conteúdo}

Repudiando a metafísica, os jovens redactores de A Crítica, invocando os nomes de Blainville, Augusto Comte e Bertillon e meditando sobre as influências que o meio exerce sobre os seres vivos, afirmam-se como «sectários do método experimental» (n. ${ }^{\circ}$ 1, p. 3, col. 1).

Com esta perspectiva de fundo e em artigos vários reflectem sobre os novos ditames da ciência em diversas áreas do conhecimento e do saber, nomeadamente ao nível da:

- Economia: é Júlio de Faria quem, no artigo intitulado «Estado da Ciência Económica», nos refere: «Hoje mesmo, se é que está precisamente determinado o campo da ciência económica... urge fazer um esforço avultado e dispender muito tempo para conseguir o complemento desta importantíssima secção dos conhecimentos humanos» (n. ${ }^{\circ}$ 2, p. 7, col. 2).

- História: tomando como exemplo a obra, recém-publicada, de Manuel Bernardes Branco, El-Rei D. Manuel, que comentam, não deixam de expor a sua concepção de história, quando defendem que "para uma indução histórica 
ser completa é indispensável investigar a sucessão ininterrupta das coisas sociais, é mister encontrar os consequentes e os seus antecedentes» (Idem, p. 5, col. 2).

- Literatura: embora se reconheçam os prós e os contras das auto-biografias, também não deixa de se referir que, apesar de tudo, «nunca podem representar uma observação completa nem indicar uma verdade exacta» (n. ${ }^{0} 1$, p. 3, col. 2).

Destaca-se ainda neste periódico:

- Elogio público ao Dr. António dos Santos Pereira Jardim, professor da Faculdade de Direito da Universidade de Coimbra, que acabara de falecer. Referindo-se-lhe, Lomelino de Freitas, à boa maneira académica, escreveu: «Dobrou o portal do túmulo o respeitável e simpático velhinho, o amigo sincero da mocidade estudiosa... os bons vão e os maus ficam», para, depois, concluir: «nos cemitérios... consumir-se-ão os corpos, transformar-se-á a matéria, mas nunca se apagará a memória gratíssima daqueles que praticaram o bem e foram escravos do dever» (n. ${ }^{\circ}$ 2, p. 1).

- Apreciação da obra de António Fogaça.

- Poesia.

Completa-se este periódico com a secção "Variedades», onde se dá conta de uma proposta para abolição do foro académico, de notícias de Camilo Castelo Branco e de novas publicações. 


\section{3 - GRÓNICA LITERÁRIA DA NOVA ACADEMIA DRAMÁTICA}

Coimbra, Imprensa da Universidade

29 Fevereiro 1840 - 8 Maio 1841

\section{Responsáveis}

Presidente: José Freire de Serpa Pimentel

Relator: António José Marques Correia Caldeira Secretário e Vice-Secretário: Rodrigo José de Morais Soares e António Augusto Teixeira de Vasconcelos

Colaboradores: Luís da Silva Mousinho de Albuquerque, Adrião Pereira Forjaz de Sampaio, Anselmo José Braancamp, José Maria de Almeida Teixeira de Queirós, J. Artur, Mendonça Falcão, A. A. da Silva, A. de M. Faleão, L. da Costa Pereira, J. J. da Silva Pereira e outros.

Formato(s): 15,5 x 21,5 cm 12 x 19,5 cm

Periodicidade: Semanal/Quinzenal

Preço: Trimestre-480 réis • Avulso - 60 réis

Páginas: Vol. I - $348 \bullet$ Vol. II - 338
Cotas:

BN: J. 87B.

BGUC: $10-3$ - 21- 17

BPMP: L - 11- 50

BMC: GHC -2

\section{Objectivo}

«Agora que já não é de uso adestrarem-se os mancebos no esgrimir da espada, no enrestar da lança, no embraçar do escudo... agora que ao rude guerrear daquelas bárbaras eras sucedeu mais civil e cavaleiroso disputar de cultivados engenhos e literários ademans... agora queremos nós também entrar, campeões nóveis, pela arena literária... queremos em instrutiva palestra fraternal longe do tumultuar das paixões ir desgastando este perigoso alvorecer da vida, que através de arrojos, inconstâncias, e desejos vai assomando pelas nossas almas e corações de mancebos. Queremos alfim deixar um padrão indelével de agradecimento e de saudade no berço comum das nossas juventudes, na risonha pátria das lusitanas letras, na fonte pura e cristalina, onde viemos de longes terras beber o precioso leite da instrução e encetar briosa carreira de homens.

Arriscado e temerário empenho é por ventura este, a que nos arrojamos... Foramos nós um punhado de moços desajudados e inexpertos, quando em 21 de Fevereiro de 1838 concebemos a ideia grandiosa de formar em Coimbra 
um estabelecimento dramático, que, único deste género em todo o Portugal, rivalizasse com os melhores teatros do reino e servisse de proveitosa diversão à mocidade académica, nas poucas horas que diariamente lhe cabem de usual descanso...

Reparamos os desmoronados muros do extinto colégio de S. Paulo; e as mesmas paredes... vão agora, após três séculos de estúpido silêncio, testemunhar a festa e o triunfo da nossa patriótica regeneração das letras.

Para dar uma vida real e um nome indelével à ilustre associação a que pertencemos, era necessário alevantar-lhe um padrão... esse padrão... é a imprensa... e no intuito glorioso de aumentar o explendor da associação, derramar os conhecimentos dramáticos, honrar a literatura nacional e promover o gosto das belas-artes, vai dar começo à publicação do seu periódico» (Crónica Literária da Nova Academia Dramática, n. ${ }^{\circ}$ 1, 29 de Fevereiro de 1840, pp. 1-3).

«Durante o impedimento do Sr. António José Marques Correia Caldeira... a Direcção do Instituto Dramático nomeou editor responsável o Sr. António Augusto Teixeira de Vasconcelos, a quem deve ser dirigida... toda a correspondência... ou para remeter qualquer artigo para ser inserido na Crónica, na certeza de que sendo esta empresa puramente literária, a Direcção terá sumo desgosto se houver de rejeitar algum artigo, que lhe remetam por tender a fins políticos» (Idem, p. 16).

\section{Conteúdo}

Em 1837-38, houve tumultos, na Associação do Teatro Académico, que funcionava no Colégio das Artes, por causa da vinda ali de uma companhia espanhola de declamação, baile e canto. Então, alguns estudantes resolveram distanciar-se e fundar uma nova associação, a qual se instalou, depois da respectiva autorização, no Colégio de S. Paulo. Assim nasce a Nova Academia Dramática, que se dividiu em três classes: Instituto Dramático, Instituto de Pintura e Instituto de Música. Foi do primeiro destes institutos que saiu a publicação Crónica Literária da Nova Academia Dramática (Cfr. José Pinto Loureiro, $O$ teatro em Coimbra. Elementos para a sua história, Coimbra, 1964). Trata-se, como o próprio título sugere, de um periódico que versa, fundamentalmente, assuntos de natureza literária e de teatro.

Compõem esta publicação dois grossos volumes, embora com formatos ligeiramente diferentes: o primeiro, de maior configuração, contém 384 páginas; 
o segundo fica-se nas 338. De salientar que do n. ${ }^{\circ} 20$, do primeiro volume, faz parte um suplemento intitulado «Suplemento à Crónica Literária n. ${ }^{\circ}$ 20» e que contém o «Regulamento para a aprovação, publicação e prémios das peças oferecidas ao Instituto Dramático da Nova Academia Dramática em Coimbra».

Na Crónica Literária da Nova Academia Dramática perpassam grandes temas como:

- Teatro: numa espécie de revista teatral, dá-se conta das peças representadas na Nova Academia desde a sua instalação; artigos sobre teatro português; peças dramáticas e sua apreciação; arte-dramática: clássicos e românticos.

Fala-se também do teatro na Grécia, no artigo «Dos costumes, comércio, jogos e teatro dos gregos» de J. J. da Silva Pereira.

- Língua e Literaturas: Com o título de «Desejos de um amigo da Literatura Portuguesa», A. M. Faleão escreve: «Tomará eu que alguém acudisse à bela língua portuguesa que tão desprezada está, tão abandonada e maltratada de seus próprios naturais. A cada passo estamos vendo empregados nos escritos científicos, nos discursos públicos, nos papeis oficiais e até nas leis, vocábulos, frases e modos de falar, não só estranhos ao idioma pátrio... mas também de mau gosto..., contrários ao sistema da gramática portuguesa...» (p. 253). Como resposta, seguem-se um conjunto de artigos, com considerações várias e incursões históricas, sobre o estudo da língua portuguesa; Cancioneiro de Garcia de Resende e ainda um conjunto de estudos sobre os poemas herói-cómicos: Hissope e Reino da Estupidez. Sobre este último disse: «Mesquinha e pouco nobre e decente foi por certo a ideia de levar ao cabo tal obra... lançando uma nódoa na reputação literária da nossa única universidade, que nessa época desmentindo os autores do poema florescia em espíritos ilustrados» (p. 205).

No âmbito da literatura estrangeira refere-se o artigo «Lamartine», sobre o poeta do mesmo nome, extraído do Correio Nacional de Madrid e «Poesia descritiva dos antigos comparada com a dos modernos. Extractos do Génio do Cristianismo de Chateaubriand», de L.P.P. de Castro.

- História de Portugal: com o título de «Inéditos», reproduz-se, ao longo de vários números, um manuscrito que foi oferecido ao Instituto Dramático, onde constam a vida e obra dos homens que escreveram sobre a nossa história, acompanhadas de uma apreciação crítica. Compôs o seu autor este manuscrito, «no mui louvável intuito de guiar a mocidade nos estudos preliminares da história portuguesa» (pp. 7-8). São eles: Rui de Pina, Cristovão Rodrigues Azinheira, Fernando de Goez Loureiro, Fr. José Teixeira, Duarte Nunes de Leão, Pedro 
de Mariz, Pe. António de Vasconcelos, Fr. Bernardo de Brito, Fr. António Brandão, Fr. Francisco Brandão, Fr. Rafael de Jesus, Fr. Manuel dos Santos, Manuel Constantino, Luís Coelho de Barbuda, Álvaro Ferreira de Vera, Manuel de Faria e Sousa, António de Sousa Macedo, Rodrigues Mendes da Silva, António Veloso de Lira, D. Luís de Menezes e Fr. Manuel da Rocha; D. Sancho II - memória e S. Francisco de Borja.

- Economia e Estatística: economia política (necessidade do seu estudo, objecto, fins, noções gerais de utilidade, valor, riqueza e outras); quadro histórico da economia nacional (ensaio); agricultura (importância e necessidade de uma legislação que a defenda); Estatística (utilidade do seu estudo, apontamentos históricos).

- Jurisprudência: jurisdição orfanológica dos juízes de paz; direito romano e direito canónico na Alemanha.

- Artes: artigos sobre pintura e belas-artes.

A par destes temas, muito espaço para criação literária que se traduz em romances, crónicas, poesia, crítica literária e textos de carácter moralizante.

Completam esta publicação pequenas notícias do Instituto, da Universidade, pensamentos e máximas e ainda anúncios e apreciações de publicações literárias. Ao nível do Instituto salientamos os nomes das personalidades que fazem parte das três classes que o compõem, respectivas direcções e sócios. 


\title{
44 - GRÓNIGA TEATRAL DA NOVA ACADEMIA DRAMÁTICA
}

\author{
Coimbra, Imprensa da Universidade \\ 1839 \\ Responsáveis \\ Direcção do Conservatório Dramático \\ Presidente: Rodrigo José de Morais Soares \\ Secretário: José Freire de Serpa Pimentel \\ Relator: José Maria Eugénio de Almeida \\ Membros do Conservatório: António José Marques \\ Correia Caldeira e João das Neves Gomes Eliseu \\ Colaboradores: Não indica \\ Formato: 22 x $16 \mathrm{~cm}$ \\ Periodicidade: Não indica \\ Preço: Não indica \\ Páginas: 49
}

Cotas:

$\mathrm{BN}$ : -

BGUC: Misc. 138

BPMP:

BMC:

\section{Objectivo}

«Quando no ano pretérito de 1838 reunimos os nossos esforços para edificar um Teatro Académico, no qual em honesto passatempo, e útil instrução empregássemos as poucas horas, que nos cabem de usual descanso no estudo das aulas, logo assomou em os nossos espíritos a formosíssima ideia de um aperfeiçoamento mais ilustrado e subido assim na grandeza e contextura material da obra, como no progresso moral dos conhecimentos dramáticos, ainda tão pouco vistos e estudados entre nós; e tanto para se verem e estudarem, como capítulos de uma educação perfeita e delicada, - castigadores dos costumes, - e espelho das paixões e vicissitudes humanas.

Temos actualmente a satisfação de ver coroados os nossos ardentes desejos em ambos estes particulares. A obra do teatro, fruto dos esforços, zelo e constância da Associação, cresce grande e formosa à sombra das simpatias e coadjuvação de grande parte do magistério académico, e outras pessoas sisudas e respeitáveis da cidade. E não é em parte menos satisfeito o nosso outro desejo; porque forão instituídos um Conservatório Dramático, um Conservatório de Música e outro de Pintura... 
Chamados pelos votos dos nossos consórcios a desempenhar os difíceis cargos de membros e directores do Conservatório Dramático, quisemos dar começo aos nossos trabalhos com a versão em linguagem da excelente peça de Mr. Alexandre Dumas, a Teresa que aprovamos e fizemos ensaiar para ser declamada em uma das primeiras récitas... Fizemos todavia quanto em nós estava para que o estilo e termos da versão fossem verdadeiramente portugueses, já que o drama o não podia ser. E, se por ventura nos não faltarem no ano por vir saúde e tempo, talvez caminharemos mais avante na carreira dramática dando à luz novas peças, já vertidas, já imitadas, já originais conforme em as nossas posses for cabendo, abrindo por esta maneira um caminho, que tíbios, e receosos encetamos, porém, onde deixamos aos nossos sucessores largo campo para colherem um dia mais sasonadas e gloriosas palmas» (n. ${ }^{\circ}$, pp. 1-2).

\section{Conteúdo}

Trata-se de uma publicação cuja finalidade principal é divulgar teatro.

Como se refere nas palavras transcritas, nesta Crónica publica-se uma tradução do drama de Alexandre Dumas intitulado Teresa. 


\section{5 - O ESCOLÁSTICO}

Jornal Recreativo e Literário

Cotas:

Coimbra, Oficina de João Tisse

BN: -

3 Janeiro 1852 - 15 Maio 1852

BGUC: -

BPMP: -

BMC: GHC $-19 / 4$

Responsáveis: Não indicados

Formato: 15,5 x $22 \mathrm{~cm}$

Periodicidade: Semanal

Preço: Não indicado

Páginas: 80

\section{Objectivo}

"Aí nos vem importunar este novo sangessuga, diria alguém que olhe para este jornal, pois enganam-se lhe dizemos nós, porque não havemos de cansar os nossos leitores com artigos massadores, além disso a modicidade do preço não tem limites e por conseguinte não havemos de causticar por modo nenhum os nossos benévolos leitores e assinantes. Faltam ele jornais, continuaria esse alguém, mas nós respondemos-lhe como Santo Agostinho: "Convem publicar muitos livros com diferente método, bem que com a mesma intenção, sobre uma mesma matéria, para que deste modo logrem muitos saber a mesma doutrina, estes debaixo duma forma, aqueles debaixo doutra».

E agora se disserem mesmo alguma coisa, o que lhe respondemos é que se não quiser não lei nem assine, pois não lhe metemos espadas ao peito».

(O Escolástico, n. ${ }^{\circ}$ 1, 3 de Janeiro de 1852, p. 3).

\section{Conteúdo}

Segundo nos informa Carneiro da Silva, o jornal $O$ Escolástico é «o mais antigo jornal académico manuscrito» (Ob. cit., p. 59).

Redigido por estudantes de quem desconhecemos os nomes, porque não indicados, este periódico afirma-se como um jornal literário e recreativo. 
Formando um volume com 80 páginas, a sua estrutura é a mesma, nos dezanove números que compõem a colecção. O texto é, por vezes, acompanhado com desenhos de tipos académicos e de naturais de Coimbra. Apresenta um índice, mas só até ao n. ${ }^{\circ} 10$.

Com um interesse bastante modesto, para além de alguma criação literária traduzida em romances, contos, poesia e outros pequenos textos, uma boa parte do jornal é dedicada a curiosidades, pequenas notícias de Coimbra, anedotas, charadas, enigmas e até pensamentos morais como este: «Quem quiser ser rico, não aumente na riqueza, mas diminua na cobiça: não é pobre o que tem pouco, mas o que deseja muito» (n. ${ }^{\circ}$, p. 22 , col. 1 ).

Em pequenos e simples textos, entre outros assuntos, fala-se ainda de: Coimbra, o Carnaval em Coimbra, uma Sabatina, a cabra, causas do espirro, o progresso literário e jornalístico em Coimbra. Referindo a este último, questionam-se para que servem tantos jornais e respondem: «A maior parte, os políticos, em defender as suas opiniões, com quanto muitas vezes erróneas, e combater as dos que não professão essas mesmas opiniões, e que aproveita isto? Nada, se nada aproveita é nocivo. Essa diminuta parte os literários não são suficientes, pelo seu pequeno número para levar a Instrução a toda a parte». (n. ${ }^{\circ} 7$, p. 29, col. 2). 


\section{6・ ESTREIA LITERÁRIA}

Jornal Recreativo (1)

Coimbra, Imprensa da Universidade

1 Março 1858 - 1 Abril 1860

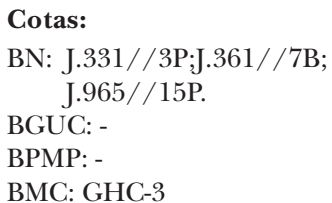

Redactores: António Manuel da Cunha Belém, Francisco de Paula Santa Clara, J. Machado Cabral e Castro e Bernardo de Albuquerque e Amaral

Colaboradores: Amélia Janny, Márcia do Couto Zagalo, Agostinho António do Souto, Alexandre Magno de Castilho, António Lopes dos Santos Valente, António Maria Vieira da Costa Ribeiro, António Pereira Zagalo, António Teodoro Taborda Pignateli, Carlos José de Oliveira, Eduardo de Oliveira, Francisco António Alves, Francisco de Castro Freire, José da Silva Mendes Leal, Lino Augusto de Macedo, Manuel José Vieira, Manuel Justino Pires, Miguel Moreira da Fonseca, Sebastião de Almeida e Silva, Severino de Azevedo, Vicente Luís de Abranches e J. J. Pereira Abranches

Formato: 16 x $18 \mathrm{~cm}$

Periodicidade: Bimensal

Preço: Trimestre -240 réis

Páginas: 4 - 12

\section{Objectivo}

«Mais um jornal sai a afrontar os escolhos da publicidade!... não o hostilizeis, 132 que a sua missão é nobre!... prestai-lhe mesmo o vosso auxílio, que assim concorreis para uma obra meritória!...

(1) A partir do n. ${ }^{\circ}$ 7, de 1 de Novembro de 1859, há uma alteração no subtítulo. O jornal passa agora a subintitular-se Jornal científico e recreativo. São os próprios redactores que reconhecem uma nova postura, quando escrevem: «mas o nosso jornal declina muito do recreativo para o instrutivo, e os actuais redactores prometem que a maior parte dos seus artigos serão extraídos antes para o útil, que agradável» (n. ${ }^{\circ}$ 7, 1 de Novembro de 1859, p. 49, col. 1). 
Não foi a ambição de renome, nem o orgulho da publicidade, que suscitou aos colaboradores deste jornal a ideia da sua criação. Não foi também um mero passatempo, ou uma vanglória, que os resolveu a entregarem à estampa as primícias da sua vida literária!... O seu fim é mais sublime; pois que, se alguns mancebos pertencentes à corporação académica, empreenderam esta publicação, foi para, com os proventos dela, coadjuvarem um colega e irmão, que, quase nos fins da sua lide científica, se via pouco favorecido dos meios da fortuna!...

A ideia é nobre! E vós haveis não só de a aplaudir, mas até de corresponder a ela, prestando os vossos bons auxílios a esta nova subscrição literária, na qual cada um dos contribuintes vem lançar o seu óbolo intelectual, que depois se há-de converter em rico tesouro material, a proveito de um filho da ciência.

Falar-vos em promessas seria louca pretensão! Os colaboradores deste jornal abundam em bons desejos; mas, dando-vos na Estreia Literária os seus primeiros ensaios como escritores, não vos podem assegurar profundos estudos científicos, nem mimosas produções literárias; e a sua própria indigência os faz implorar a todos, os que cultivam as letras pátrias, se dignem concorrer para um jornal, que tem a cumprir tão louvável missão; e assim, se a sua Estreia lhes não poder servir de padrão de glória literária, ser-lhes-á brazão glorioso do amor fraternal, que deu origem a tão nova como sublime ideia» (n. ${ }^{\circ}$, Coimbra, 1 de Março de 1858, p. 1).

«Este jornal, cujo fim é bem conhecido, não teve nem podia ter a pretensão de instruir. As estreias literárias de alguns mancebos, que começavam desvelados a cultura das letras pátrias, não podia arrogar a si o pomposo título de jornal instrutivo! Também se não podia comprometer a, sobre os variados ramos das ciências, difundir as luzes, com que o progresso da observação, da experiência e do profundo cogitar dos homens doutos as costumam enriquecer. Não! Esta singela publicação, se era o primeiro ensaio nos campos da literatura, era também o primeiro e vacilante passo no trilho das ciências!... passo arriscado e tímido, que mais poderia mostrar a aplicação e aproveitamento de quem encetava apenas este difícil caminho, do que os resultados brilhantes de profundos estudos e aturadas locubrações! Também por isso lhe não competia o título de jornal científico!

O seu escopo era agradar a todos; e como a uns recreia mais a leitura dessas páginas, que à ciência consagra, a outros só apraz o divagar nos jardins da literatura, não deixa de ser recreativa a Estreia, ainda quando dos conhecimentos científicos se ocupa, com aquele comedimento, que às suas forças compete» (n. ${ }^{\circ}$, p. 1, col. 1). 


\section{Conteúdo}

Como se deduz das palavras que lhe servem de apresentação, este periódico apareceu por uma questão de filantropia. O produto das vendas destinava-se a ajudar um colega que se encontrava em dificuldades económicas.

Com uma vasta equipa de colaboradores, procura não só recrear, lendo, mas também instruir, divulgando conhecimentos em diversos domínios do saber.

Compõe-se esta publicação de trinta e cinco números, com o mesmo formato, repartidos por dois volumes. Do primeiro volume fazem parte dezoito números, mas nem todos com o mesmo número de páginas. Os restantes, com oito páginas cada, integram o segundo volume. Apenso ao número treze deste volume, um documento de três páginas intitulado "Análise do Acordão do Conselho de Decanos de 26 de Janeiro de 1860", da autoria de Bernardo de Albuquerque e Amaral, estudante do quinto ano de Direito.

Os artigos e textos de Estreia Literária abarcam várias áreas do saber. Neles se reflecte, se tecem considerações e se expõem teorias sobre problemas vários. Numa breve síntese, é possível identificar questões como:

- Economia: interesse, importância e necessidade de conhecimentos económicos; o estudo da economia política e sua importância, dentro de um estado (a questão dos impostos, comércio e indústria, a unidade monetária, o crédito, os juros, a usura, monopólio e liberdade dos cidadãos); direito e economia.

- Filosofia: filosofia e ciência; Deus, homem e religião; homem, sociedade e sociabilidade - Hobbes, Rousseau e Bentham; a liberdade; o egoísmo; a consciência; o homem e o trabalho; o homem e a avareza; a questão do tempo; artes e filosofia-opiniões de filósofos gregos e romanos.

- Direito: o projecto do código civil português; ciências-naturais e o seu contributo para a ciência jurídica; direito civil e direito penal; questões de direito sucessório; a importância da filosofia do direito; matrimónio e divórcio; a pena de morte; o problema da indigência; problemas no exercício da justiça (o direito de punir, a inimputabilidade, a equidade).

- História: apontamentos sobre comércio na antiguidade; a sumptuosidade entre os romanos (a habitação); a morte de César; leis de amortização / desamortização; relações igreja-estado; D. Sebastião e a jornada de África; antiguidades de Elvas. 
- Ciências: reflexões sobre investigação científica; questões de botânica (estrutura das plantas e seus órgãos); a importância do estudo da química para a fisiologia; mecanismos de nutrição e secreção; a acção dos ácidos como refrigerantes na economia-diversas doutrinas; a ciência estadística - sua importância e aspectos.

Breves considerações também sobre artes e literatura, nomeadamente sobre o romance e a importância daquelas no desenvolvimento civilizacional.

O mesmo sobre educação e instrução, sobretudo a primária (frequência dos alunos, livros, vencimentos aos professores).

A existência ainda de textos de carácter psicológico, em «Era na Infância».

No domínio da política constata-se um certo distanciamento. Apenas uns breves considerandos sobre "o poder moderador" e "a Câmara dos Pares». Depois de se ponderar sobre o que esta representa, opina-se «pela abolição do pariato que repugna... com o espírito da época actual» (n. ${ }^{\circ}$ 15, 1 de Março de 1860, p. 116, col. 2).

Estreia Literária contém ainda duas secções praticamente permanentes: "Cenas Contemporâneas da vida académica. Quase romance da actualidade», cujo objectivo «é de todos bem sabido que aqueles que têm cursado a Universidade gostam de ler tudo que diga a ela respeito... o encontram em letra redonda estas reproduções das cenas da sua vida académica, é como uma espécie de alpondras por sobre as quais a memória vai atravessando o letes do passado» (n. ${ }^{\circ}$ 2, 15 de Março de 1858, pp. 7-8). Estes textos têm uma certa importância, na medida em que se podem colher informações e elementos para a história da academia. A outra secção é «Charadas», cuja finalidade é ajudar a passar o tempo, com enigmas e anedotas.

Com carácter efémero, a secção "Recordações de Coimbra», que não foi além do n. ${ }^{\circ}$ 11, de 15 de Agosto de 1858.

Completa-se este periódico com textos literários (traduções de obras de Valério Máximo) e poesias.

Neste periódico reproduz-se o discurso que António João da França Bettencourt, lente de Teologia, proferiu, no Instituto de Coimbra, quando ali foi admitido como sócio (Apud, n. ${ }^{\circ}$ 10, de 15 de Dezembro de 1859).

Publicidade para algumas obras como a de António Augusto Teixeira de Vasconcelos, Portugal e a Casa de Bragança e de António Augusto da Costa Simões, Notícias dos Banhos do Luso. 


\section{$47 \cdot$ O ESTUDO}

Folha Literária, noticiosa e recreativa

Coimbra, Imprensa Literária

12 Março 1882 - 16 Abril 1882
Cotas:

BN: J.2460//19 V.

BGUC: -

BPMP: P/C/1098(6)

BMC: GHC $-20 / 10$

Administrador: José Júlio Pinto Soares

Redactores: A. X. P. Silva Bastos, A. M. M. Perdigão, J.

C. Correia Mourão e J. Fernandes Moura

Colaboradores: José Luís da Costa, Nicolau Pimenta, Eugénio de Castro e Bernardino Vidigal

Formato: 22,5 x 32,5 cm

Preço: Trimestre -300 réis • Avulso - 40 réis

Periodicidade: Semanal

Páginas: 4

\section{Objectivo}

«É este o título de um novo semanário que brevemente principiará a sua publicação.

É este jornal publicado por alguns jovens rapazes que entretêm as suas horas de ócio instruindo-se e ao mesmo tempo desenvolvendo-se para um dia, se poderem apresentar ao público com o rosto descoberto.

É antigo costume quando um jornal começa a sua publicidade fazer o seu programa; portanto nós apesar de humildes e obscuros faremos o nosso que em pouco se encerra.

Este jornal não é orgão duma certa e determinada sociedade; é, inteiramen-

136 te independente, literário, noticioso e recreativo e como tal completamente alheio à política.

O nosso único fim será entreter os nossos leitores, se isso podermos conseguir, e muito principalmente instruir-nos a nós mesmos... Repetimos que não somos políticos. Está no espírito do século todos serem, republicanos, e a maior parte deles nem tão pouco sabem o que é ser republicano. Vê-se principalmente isto na nobre mocidade a que temos a alegria de pertencer... Aqueles que hoje são republicanos, seriam amanhã monárquicos se por acaso fosse essa a moda que aparecesse...» (O Estudo, prospecto que acompanha o jornal). 


\section{Conteúdo}

O Estudo é uma pequena publicação, que não foi além de seis números, todos com o mesmo formato e número de páginas, e que visa, como jornal que é, um certo entretenimento dos seus leitores, ilustrando-os. Daí que o próprio periódico se defina e afirme como uma «folha literária, noticiosa e recreativa».

A maior parte das suas páginas são ocupadas com textos literários, em prosa e em verso, mas onde não faltam, também, breves notícias sobre figuras da nossa literatura como é o caso de Diogo Bernardes. A existência, em todos os números, de excertos de um «Folhetim».

Para além do âmbito literário, a ilustração pode passar, também, por outras cambiantes como, por exemplo, um artigo de carácter doutrinário e até uma breve e simples notícia exarada num pequeno texto. Neste sentido, apesar de o jornal se dizer «alheio à política» e de os seus responsáveis afirmarem que «não somos políticos», reconhecem, no entanto, que o espírito do século está mais em consonância com o republicanismo, embora uma grande parte da mocidade não saiba ainda muito bem o que é «ser republicano». No artigo «O Cristianismo» são evidentes as simpatias por um certo anticlericalismo, pela revolução francesa e pela figura do Marquês de Pombal. Aqui se acusam os clérigos de ver na religião fundada por Jesus Cristo, símbolo de bondade e amor, «uma fonte inesgotável de riqueza e poder» (n. ${ }^{\circ} 4$, p. 1, col. 1). Citando exemplos literários, foram a riqueza e a ânsia de poder que levaram à dominação e à escravização como aconteceu nas cruzadas e, depois, ao aparecimento de Lutero e Calvino; fortes críticas também para os jesuítas.

Também num pequeno texto intitulado «Covilhã» se crítica o fanatismo religioso que se verifica nesta terra (Cfr. n. $\left.{ }^{\circ} 6\right)$.

O carácter noticioso afirma-se, não só em «Noticiário», mas, fundamentalmente, na secção permanente "Coimbra durante a semana», onde Nicolau Pimenta nos faz uma espécie de crónica do que naquela terra se vai passando, durante sete dias, apesar de reconhecer tratar-se de uma cidade onde predomina algum marasmo, o que o levou a escrever, em tons de ironia, o seguinte: «Schiu!... Silêncio leitor, não acordemos a cidade» (n. ${ }^{\circ}$ 4, p. 2, col. 2). 


\section{8 • ESTUdOS COSMOLÓGICOS}

Publicação Quinzenal

Coimbra, Imprensa da Universidade

20 Maio 1870 - 21 Novembro 1870
Cotas:

BN: J. 172 B.

BGUC: -

BPMP: P/B/2165(9)

BMC: GHC $-20 / 1$

Redactores: A. M. de Sena, Bernardino Machado, F. A. Correia Barata

Colaboradores: Augusto Fuschini, F. Teixeira de Queiroz, Augusto Rocha, Alfredo Rocha Peixoto, M. M. de L. Figueiredo, José Augusto Teixeira

Formato: 18,5 x 27,5 cm

Periodicidade: Quinzenal

Preço: 100 réis - Coimbra $\bullet 110$ réis - Fora de Coimbra

Páginas: 16

\section{Objectivo}

«Para uns a imprensa é a tribuna onde se proclama a verdade nova. São estes os mestres da ciência. Para outros é o altar onde se veneram as maravilhas do génio do homem e se aprende a religião do saber. Somos nós. Para todos mestres e discípulos, sacerdotes e adeptos - a imprensa é uma necessidade, a propaganda científica uma obrigação.

É por estarem convictos desta obrigação que apresentamos à apreciação pública estes estudos, que são o fruto dos nossos trabalhos. Com eles é nosso intuito, não descobrir mas propagar...

Concorrendo com aquilo de que somos capazes para a grande obra universal, seguimos a ideia do século: a difusão de luzes em todos os sentidos; a colaboração imensa de todos para a conquista da verdade. Daqui a rapidez de cada progresso, que faz do século XIX o mais glorioso de quantos a história conta...

Em harmonia com as nossas forças, estes Estudos são despertenciosos e humildes. Não podem seguir os passos de Galileu ou Descartes, encetam apenas o trilho apontado por Louis Figuier.

Não foi sem hesitação que para eles adoptámos o epíteto de - Cosmológicos. Era forçoso que o título indicasse o objecto desta publicação, e recorremos por 
isso à classificação. Entre as classificações enciclopédicas deveramos escolher as objectivas: assim o fizemos, seguindo a d'Ampère exposta na sua Filosofia das Ciências.

Debaixo da designação de ciências cosmológicas compreendem-se as ciências matemáticas puras e aplicadas, as ciências físicas, as ciências naturais e médicas, e ainda um grupo de ciências, cujo objecto se dirige especialmente à existência material do homem, tais como a agricultura e outras.

Duas observações precisamos agora fazer. É a primeira, que o título escolhido nos exprime uma questão matesiológica... A segunda é, que o termos principalmente em vista as ciências puras não significa desmerecimento ou pouca valia, que para nós tenham as ciências práticas...

Devemos confessar, em primeiro lugar, que a índole dos nossos estudos académicos é principalmente especulativa... Estuda-se a ciência pela ciência» (Estudos Cosmológicos, n. ${ }^{\circ}$ 1, Coimbra, 20 de Maio de 1870, pp. 1-2).

\section{Conteúdo}

Estudos Cosmológicos é uma pequena publicação, cujo objectivo principal é divulgar conhecimento científico, sobretudo ao nível e no âmbito das ciências.

Ao longo dos seus três números, a estrutura deste periódico é a mesma, quer quanto ao formato, quer ao número de páginas de cada um. Uma diferença é, no entanto, de assinalar: o n. 3 não tem subtítulo. Este facto é explicado pela direcção, que conhece ser difícil dar à luz, quinzenalmente, este periódico, pelo que «resolvemos publicar mensalmente um número de igual extensão» (n. ${ }^{\circ} 3$, p. 48, col. 2). É possível que este número que aqui se anuncia, seja o n. ${ }^{\circ} 4$, datado de 1871, de que Carneiro da Silva nos fala (Ob. cit., p. 62), mas que não integra a colecção por nós consultada, na B. M. C.

De salientar a secção «Expediente», espaço reservado a anunciar as publicações recebidas, fazer agradecimentos e prestar informações.

No artigo «Um esboço», Augusto Fuschini faz um elogio à ciência. Recusando e criticando os que desejam uma restauração do passado, faz uma profissão de fé no mundo e no progresso: «Ensinar o povo a discutir, imprimir-lhe no ânimo o desprezo pelo dogma e o desejo da persuasão, é fazer uma 
revolução enorme sem perda de tempo e vidas; e se é certo que sós não a podemos fazer, é também certo que os esforços combinados darão a grande resultante - o progresso» (p. 32, col. 1).

Em artigos e domínios diversos, aposta-se na divulgação do conhecimento. Assim: ao nível da Botânica, publica-se o «Catalogue. Des plantes économiques et industrielles, cultivées au Jardin Botanique de l'Université»; no domínio da Química, José Augusto Teixeira reflecte sobre «Unidade da Química» e José Saraiva escreve o artigo «Alcaloides»; no campo das Ciências Naturais, Augusto Rocha disserta sobre «Animais Domésticos? Domesticidade?» e F. Teixeira de Queirós «Simetria em «a natureza», para, na física e astronomia, M. M. de L. Figueiredo e Rocha Peixoto, escreverem: «No ensino da mecânica racional dever-se-á subordinar o estudo da dinâmica ao da estática ou seguir a ordem inversa?» $\mathrm{e}$ «Breves considerações sobre os cometas».

Completa-se este periódico com a divulgação dos «Apontamentos de Física-Matemática. Dissertação inaugural para o acto de formatura na Faculdade de Matemática, no dia 14 de Junho de 1869», da autoria de Rocha Peixoto e com a representação que os alunos da Faculdade de Medicina dirigiram a ElRei, por causa do Curso de Medicina e Cirurgia criado pelo decreto de 5 de Dezembro de 1836, extinto pelo decreto de 26 de Abril de 1842 e restabelecido pelo decreto de 22 de Junho de 1870. 


\section{9 • ESTUdOS MÉdICOS}

Orgão da Sociedade dos Estudos Médicos de Coimbra

Coimbra, Imprensa da Universidade

1 Março 1878 - Maio 1881

Directores: Luís Augusto Teixeira Lobato, António Dias Gouveia, Eduardo Burnay e Paulo Guedes da Silva Almeida

Redactores: Dr. António Maria de Sena, José de Azevedo Castelo Branco, Francisco da Graça Miguens, João Henriques Tierno, Eduardo Burnay, Luís Pereira da Costa, Dr. Jacinto da Silva Correia, Dr. Daniel de Matos, António Maria do Carmo Rodrigues, António da Costa Freire, Augusto Barjona de Freitas, Jaime Adolfo Mauperrin Santos, João Monteiro de Sacadura, Paulo Guedes da Silva Almeida, Narciso Alberto de Sousa, Adriano Xavier Lopes Vieira, João Bentes Castel-Branco, Alberto de Oliveira Lobo, António Maria Henriques da Silva, José Afonso Baeta Neves e Lopo José de Figueiredo Carvalho

Colaboradores: Augusto Rocha, Inácio Rodrigues Costa Duarte, J. de Mariz Junior, J. Vitorino de Freitas, M. Aguedo, A. J. Lopes, A. Filipe Simões, Júlio de Oliveira Batista, José Epifânio Marques, Francisco Batista Zagalo, José Barbosa Leão, José Albano Segurão, Eduardo Abreu e Francisco António Rodrigues Gusmão

Formato: 23 x $30 \mathrm{~cm}$

Periodicidade: Bimensal ${ }^{(1)}$

Preço: Avulso - 100 réis

Páginas: 248

\author{
Cotas: \\ BN: J. 1396 B.; J. 1663//52V. \\ J. $2456 / / 32 \mathrm{~V}$ \\ BGUC: 10 - 9- 15 \\ BPMP: - \\ BMC: GHC -60
}




\section{Objectivo}

«No título que damos a este jornal vai a sua definição. Tal título não é, nem vaidoso, nem modesto: é verdadeiro. Assim, esta publicação tem legitimamente direito à justa consideração que merecem - o seu objecto, as ciências médicas, e o seu agente, o estudo, o trabalho.

Não é um jornal de mestres; é um jornal de estudantes, embora mestres nos guiem com o seu conselho, nos auxiliem com a sua colaboração.

É este jornal sobretudo destinado ao primeiro tirocínio da mocidade médica desta Universidade no jornalismo da ciência, pois se difíceis e escabrosos são sempre os primeiros passos na imprensa, é certo que a ciência de escrever é uma força em que se devem educar todos aqueles que não queiram fazer monopólio das verdades que possam possuir...» (Estudos Médicos, n. ${ }^{\circ}$ 1, p. 1, col. 1).

\section{Conteúdo}

Trata-se de um periódico que, conforme o subtítulo refere, é órgão da Sociedade dos Estudos Médicos de Coimbra e visa, fundamentalmente, divulgar ciência médica, entre a classe, no sentido de uma formação permanente.

A colecção completa desta publicação é de 25 números, distribuídos por duas séries, terminando a primeira com o n. ${ }^{\circ}$ 15, em Fevereiro de 1879. Todos os números têm o mesmo formato, embora nem todos o mesmo número de páginas. Alguns apresentam ilustrações relativas às matérias apresentadas.

É, essencialmente, num conjunto de artigos, abrangendo especialidades várias, que se procura divulgar a ciência médica. Ainda no âmbito da ciência e da prática médicas, há a assinalar a apresentação de alguns casos clínicos.

De referenciar aqui, também, as conferências que alunos de Medicina realizaram e de que este periódico faz eco como, por exemplo, a levada a cabo por A. Dias de Gouveia, aluno do 5. ${ }^{\circ}$ Ano, em 8 de Fevereiro de 1879, com o título de «A sífilis nas sociedades futuras" e a de Eduardo Burnay, aluno do $4 .^{\circ}$ Ano, sobre "Análise fisiológica dos tecidos», para além da reprodução de artigos de opinião como o que M. Matias Duval faz, na crítica que desenvolve à obra de Claude Bernard. 
No contexto da sua estrutura interna, são de assinalar as seguintes secções: «Bulletin pour l'étranger», onde se faz um resumo, em língua francesa, dos assuntos que integram cada número; «Boletim Terapêutico e Farmacológico», que iniciado em Novembro de 1878, contém referências importantes ao estudo dos medicamentos e sua aplicação, o que na perspectiva dos seus responsáveis tem grandes vantagens para a classe médica; «Revista Estrangeira», que é um espaço reservado a notícias de reuniões e de jornais científicos estrangeiros e que é «útil e interessante para aqueles que desejarem estar em dia com o movimento científico actual» (n. ${ }^{\circ} 19$, p. 187, col. 1); «Crónica», local onde, não só se publicam documentos vários relativos à Faculdade de Medicina, petições de alunos, mas também se dá conta das conferências realizadas e se transmitem informações da Faculdade de Medicina e da Sociedade dos Estudos Médicos; «Secção Bibliográfica», onde se indicam as publicações recebidas e, por vezes, se fazem recensões críticas a obras e se apresentam pareceres sobre determinados assuntos.

Completam esta publicação um «Relatório da missão científica que o Dr. António Maria de Sena, lente substituto de Medicina, faz ao estrangeiro, entre 15 de Novembro de 1878 e 15 de Fevereiro de 1879, e ainda um texto da autoria de M. Sieuve Nogueira sobre a «Epidemia de sarampo na vila de Caminha».

De referir, finalmente, pela sua importância, a «Estatística das principais operações feitas nos Hospitais da Universidade de Coimbra desde 1870 a 1878" e, no domínio da Clínica Escolar, a «Sinopse das operações praticadas, auxiliadas ou presenciadas pelo curso do 4. ${ }^{\circ}$ Ano de Medicina, nos anos de 1877-78 e 1879-80» e informações sobre a Sociedade dos Estudos Médicos (sessão inaugural e eleição das comissões). 


\title{
50 - A EVOLUÇÃ̃O
}

\author{
Revista quinzenal de literatura, de crítica Cotas: \\ e de vulgarização científica \\ BN: J. 453//21 M.; \\ J. $1663 / / 53 \mathrm{~V}$. \\ Coimbra, Imprensa Académica \\ Novembro 1876 - Dezembro 1877 \\ BGUC: 10 - 1- 26 - 1 \\ BPMP: - \\ BMC: GHC -4
}

Redactor: Alexandre da Conceição

Colaboradores: A. Zeferino Cândido, Barros de Seixas, Manuel Sardenha, Cesário Verde, Alfredo

Oscar May, M. Duarte de Almeida, Gonçalves

Crespo, Sérgio de Castro, Alfredo Carvalhais, Júlia Ferreira, Amélia Janny, Augusto Rocha, Consiglieri Pedroso, M. da Costa Pinto, Nunes da Ponte, António Macedo Papança, Paulo de Andrade, Gabriel Pereira, Coelho de Carvalho, Teófilo Braga, Maximiano Lemos Júnior, Silva Ramos e F. C. de Melo Leote

Formato: 23 x $31 \mathrm{~cm}$

Periodicidade: Quinzenal

Preço: 120 réis (mês)

Páginas: 96

\section{Objectivo}

«Assistimos na Europa a uma das transformações mais decisivas e brilhantes, que haverá a registar na história do espírito humano, qual é a da substituição lenta, mas constante e gradual, do velho espírito teológico e metafísico pelo espírito verdadeiramente científico da filosofia positiva...

Começam finalmente os espíritos a penetrar-se da ideia de que a evolução é o grande princípio regulador das transformações e dos progressos da socieda-

144 de, como o é dos indivíduos, como o é talvez de toda a série orgânica...

A ciência levantada finalmente acima da atmosfera asfixiante em que se finam as antigas seitas e as velhas escolas metafísicas, abandona para sempre o terreno movediço das hipóteses, reduzindo-as à sua verdadeira condição secundária de concepções provisórias, destinadas, quando muito, a guiar o observador na investigação dos factos, mas nunca a servir de base a teorias científicas, enquanto hipóteses.

A política perde de dia para dia o carácter flutuante, convencional e aventureiro que lhe imprimira o espírito juvenil e impaciente, posto que generoso, de 
jacobinismo francês, para se tornar uma verdadeira ciência, cujas leis..., são rigorosamente deduzidas da observação inteligente e despreocupada dos factos.

A literatura despe a desbotada túnica romântica... apossa-se das altas verdades da filosofia e do movimento científico contemporâneo...

Em Portugal... esta imensa transformação nas ideias e no ponto de vista crítico acha-se já brilhantemente afirmada nos estudos históricos e literários e nas concepções poéticas e artísticas...

Vai nestas leves considerações a justificação do título adoptado para este jornal.

Hão-de ser estes os princípios que nos hão-de guiar na derrota mais ou menos curta, mais ou menos obscura que esta publicação tiver de fazer. Não temos exclusivismo intolerantes de escola, nem rancores obscuros de seita literária. O nosso ideal social é a justiça, o nosso ideal artístico é a verdade» (A Evolução, n. ${ }^{\circ}$, pp. 1-2).

\section{Conteúdo}

Embora reconhecendo que o triunfo da ideologia positivista, em Portugal, era já um facto, este periódico assume-se, não só como um paladino destas novas ideias, o que justifica, no entender dos seus responsáveis, o título adoptado, mas procura, sobretudo, divulgá-las e consolidá-las. É, certamente, neste sentido que artigos como «A lenda da criação na India», onde se afirma, por exemplo, que «qualquer poderá ver que o autor do pentateuco foi um copista na compreensão fundamental, desvirtuando os mais sublimes pensamentos que encontrou na fonte» (n. 9 9, p. 70, col. 2), «A suposta necessidade de resolução do problema metafísico das causas primárias e finais», para rebater a posição dos metafísicos que afirmam que ao espírito humano é impossível renunciar aos problemas de origem, de finalidade e de essência, e «Traços gerais da filosofia positiva», de Teófilo Braga, devem ser lidos.

Este mesmo sentimento é igualmente visível ao nível da produção poética, quer na poesia intitulada "Igreja», de Barros de Seixas (Cfr. n. ${ }^{\circ}$ 7), quer nesta simples quadra, entre outras, de Manuel Sardenha que reza:

«Um filho das modernas teorias

Ousa dizer aos filhos do Evangelho:

- Ante a cruz postos sempre de joelhos!...

Tenho pena de vós, ó almas pias!» (n. ${ }^{\circ}$ 1, p. 7, col. 1) 
Ao longo dos seus doze números, todos com o mesmo formato, número de páginas e estrutura interna, são abordadas temáticas diversas que sintetizamos assim:

- Instrução Pública/Ensino: louva-se Ramalho Ortigão pelo que escreveu em As Farpas sobre esta matéria; fazem-se reflexões sobre os diversos níveis de ensino; tecem-se considerações às propostas apresentadas por aquele autor; fala-se da criação da Sociedade de Geografia de Lisboa e sua importância; reflexões várias, também, sobre o ensino da geografia - seus objectivos, métodos e programas.

- Investigação e Ciência: a Sociedade de Geografia e a investigação; a importância das viagens e expedições científicas que, para além de uma questão de carácter político e económico, têm que ser assumidas como «uma obrigação moral indeclinável» (n. ${ }^{\circ}$ 5, p. 39, col. 1); a ciência da geodesia em Portugal - o último relatório da comissão geodésica; vestígios do período glaciar no arquipélago dos Açores.

- Sociedade e Ideologia: o estado social e o desequilíbrio deste com a lei; a evolução da humanidade; evolução religiosa e filosófica; as forças próprias da espécie e as acções do meio; a mesologia e sua importância; a importância da revolução francesa; a sociedade velha e a sociedade nova «defrontando-se sempre hostis e sempre em luta, vêem-se de um lado os representantes do passado tentando avassalar, de outro os apóstolos do futuro procurando convencer» (n. ${ }^{\circ}$ 9, p. 67, col. 1); a importância da educação e da instrução: a necessidade de escolas e de professores.

- Ideologia e Política: certamente numa suposta alusão à questão ibérica, defendem-se as pequenas nacionalidades, «porque é nelas que vemos... mais consolidada a democracia, mais respeitada a liberdade, mais honrada a política e mais honesta a administração" (n. ${ }^{\circ} 3$, p. 22, cols 1 e 2); críticas aos partidos liberais pela incoerência que demonstram no carácter litúrgico que imprimem às suas festas.

No domínio da literatura, salienta-se o ensaio de Teófilo Braga intitulado «Literatura dos contos populares portugueses».

Finalmente, em «Bilbiografia» e «Publicações» dá-se conta, não só das publicações que vão saindo, mas também de algumas recensões críticas para, em «Crónica Dramática», se falar do movimento teatral e se fazerem apreciações de peças e representações. 


\section{1・A EVOLUÇÃ̃}

Semanário Republicano

Coimbra, Tipografia de Santos e Silva

27 Dezembro 1881 - 22 Julho 1882

Redactores: Manuel Duarte Laranjo, Gomes Palma, José Francisco de Azevedo e Silva Júnior

Colaboradores: Manuel da Silva Gaio, Joaquim de Araújo, Carrilho Videira, António Feijó, Augusto Tavares, Luís de Magalhães, Rodrigues Nogueira, Manuel Teixeira Gomes, Manuel Duarte Almeida, Alfredo Xavier Pinheiro, Afonso Vargas e outros

Formato: $32 \mathrm{x} 46 \mathrm{~cm}$

Periodicidade: Semanal

Preço: Série de 15 n. ${ }^{\text {os }}$ - 300 réis

Páginas: 4
Cotas:

BN: J. 775//24 A.j.j.780//23A.; J.1698//38V.; J.3593M.

BGUC: B $-18-14-3$

BPMP: COR. 2263

BMC: GHC -155

\section{Objectivo}

«Apresentando-nos na imprensa cumpre-nos expor e justificar os princípios que vamos defender.

Nós entendemos que a forma de governo que nos pode dar maior soma de garantias materiais é a República.

Dizendo-nos clara e abertamente republicanos satisfazemos um dever indeclinável da consciência e uma feição particular do nosso espírito a qual nos torna incompatíveis com as tergiversações com os rodeios.

Passou o tempo das afirmações vagas e banais. Hoje a primeira obrigação do jornalista consciencioso e digno é dizer unicamente o que pensa, é declarar formalmente o que pretende, - demonstrando verdade do seu pensamento e a justiça das suas pretensões.

É o que vamos fazer» (A Evolução, 1. 'Ano, n. ${ }^{\circ}$ 1, Coimbra, 27 de Novembro de 1881, p. 1, col. 1).

\section{Conteúdo}

Em termos de ideologia política, este periódico afirma-se como um jornal republicano e, por isso, apostado não só em denunciar a indiferença e a má 
gestão dos governos monárquicos, mas também em divulgar as novas ideias. Daí, por um lado, um discurso de protesto e, pelo outro, palavras de esperança em tempos novos.

A estrutura interna de $A$ Evolução é, ao longo de praticamente todos os seus números, sensivelmente a mesma. A primeira página é dedicada quase exclusivamente a um artigo de fundo que, podemos dizer, serve de editorial. Seguem-se, depois, um conjunto de textos que, por motivos óbvios, são de natureza essencialmente política e doutrinária.

Num desdobramento temático é possível identificar o tratamento de questões, como por exemplo:

- Filosofia política: positivismo, a função transitória do constitucionalismo, a missão da realeza, a hereditariedade política, os centenários e a filosofia positiva, o sufrágio universal, a democracia moderna;

- Forças políticas: partidos monárquicos, o partido republicano, o Parlamento e os deputados, a propaganda monárquica e republicana;

- A influência do clero: a missão dos padres, o jesuitismo;

- Instrução Pública: secularização, instrução secundária, o ensino e os professores na Faculdade de Direito, a educação da mulher, escolas profissionais, construções escolares;

- Os estudantes: A Academia de Coimbra e de Lisboa, a Federação Académica, o Centenário de Pombal e as Academias, os estudantes de Coimbra e o governo;

- Decadência de Portugal: o regime monárquico, as festas da realeza, os impostos, a ligação à Inglaterra;

A existência ainda das seguintes secções: "Noticiário» e "Câmaras Óptica», onde se divulgam as mais diversas e variadas notícias; «Revista Estrangeira» com informações de além-fronteiras, dando um relevo muito especial às francesas;

148 «Lisboa», onde se dá a conhecer um pouco o que vai pela capital e «As nossas colónias», onde se aproveita para criticar o governo pelo tipo de administração efectuada, as Congregações religiosas, problemas militares e económicos.

Para além de muitas notícias sobre a figura do Marquês de Pombal e do seu Centenário, completam este periódico os habituais folhetins, alguma poesia, reprodução de artigos saídos na imprensa, notícias de diferentes localidades do país (Odemira, Santarém e outros) e um ou outro anúncio de publicações.

Salienta-se ainda que, em 8 de Maio de 1882, foi publicado um número inteiramente dedicado ao Centenário do Marquês de Pombal. 


\section{2 - FLANANDO}

Coimbra, Tipografia França Amado (1)

26 Março 1896 - 5 Maio 1896

Director: Francisco Vale [Francisco José de Oliveira Vale] ${ }^{(2)}$

Redactores: Rolié, Quatorze, Pitonó e Barriguinha da Sé (pseudónimos)

Formato: $11,5 \times 17,4 \mathrm{~cm}$

Periodicidade: Mensal

Preço: 30 réis

Páginas: 18 - 24
Cotas:

BN: J.972//6 P; J.1267 B.

BGUC: O.S.954

BPMP: -

BMC: GHC -19/1

\section{Objectivo}

«Dizer-vos o que é esta revista desnecessário se torna, pois certamente ninguém a confundirá com as do Hospital, a que a fêmea é sujeita e a que o fêmeo o deverá ser, há tempos a esta parte.

Como todas as gazetas e artes correlativas vimos preencher uma lacuna, que faremos transbordar: as nossas colunas estão patentes; a todos não, mas só a alguns.

Propomo-nos, pela módica quantia de 30 réis, distribuir, qual nova cozinha económica-literária, uma pequena mayonnaise com preparados de feição... (Flanando, n. ${ }^{\circ}$ 1, p. 5).

\section{Conteúdo}

Trata-se de uma revista de chalaça académica, onde se descrevem alguns quadros pitorescos da vida estudantil e se ridicularizam estudantes e indivíduos da cidade.

(1) Os n. os 2 e 3 foram, depois, impressos na Tipografia Minerva Central.

(2) No n. ${ }^{\circ}$ 3, lê-se: «O Flanando pertence a Francisco José de Oliveira Vale» (p. 24). 


\section{3 - A FLORESTA}

Jornal Literário

Coimbra, [s.l.]

8 Agosto 1897

Responsáveis: Não indica

Colaboradores: Não indica

Formato: $20 \times 37,5 \mathrm{~cm}$

Periodicidade: Não indica

Preço: Não indica

Páginas: 4
Cotas:

BN: -

BGUC: -

BPMP: -

BMC: GHC -4

\section{Objectivo}

«Tenro arbusto, em meio de árvores frondosas, o nosso modesto jornalzinho surge timidamente entre os periódicos da localidade.

O seu exíguo formato é um símbolo da curta idade dos seus fundadores. Haverá quem se ria da humilde tentativa. Pode ser; mas também há-de haver quem a respeite, como uma aspiração nobre de espíritos que desabrocham, cheios de esperança, acalentados pela fé no futuro, cônscios da nobre divisa: labor omnia.

$\mathrm{O}$ que neste momento se afigura a um brinquedo pode logo reputar-se a um cometimento sério, porque a criança de hoje, se converterá no homem, de amanhã.

Bafeje-nos a protecção, e essa não no-la recusarão as almas generosas que a coragem alentar-nos-á, fazendo singrar serenamente o nosso minúsculo batelzinho nas águas azuis e tranquilas do pensamento...» (A Floresta, n. ${ }^{\circ}$ 1, pp. 1-2).

\section{Conteúdo}

A Floresta é um pequeno periódico, do qual não dispomos de elementos concretos, admitindo, no entanto, tratar-se de uma publicação de alunos dos primeiros anos do liceu, razão pela qual a contabilizamos.

Trata-se de um jornal litografado, número único, cujo conteúdo não revela grande interesse, uma vez que, para além de se contarem fanfarronices de alguém, se dá uma ou outra notícia e piada. 


\section{4 • A FOLHA}

Microcosmo Literário

Coimbra, Imprensa da Universidade (1)

25 Novembro $1868-1873$

\section{Cotas:}

BN: J. 381 B.

BGUC: 10 - 7- 14 - 10;10-9-7

BPMP: P/B/2896

BMC: GHC -2

Responsável: Faustino Sarmento

Director: João Penha

Colaboradores: Cândido de Figueiredo, José Simões

Dias, Guilherme Braga, Luís Carlos, Vasco

Hermínio, Inácio Pizarro, Guerra Junqueiro,

J. Frederido Laranjo, Vitória Coelho, Manuel

Sardenha, Alberto Pimentel, Manuel Duarte de

Almeida, M. Angélica de Andrade, Eduardo

Cabrita, A. F. Castilho, Diniz Ferreira, Sousa

Viterbo, Gonçalves Crespo, G.B. de Avelar, Luís

Jardim, J. Fontellas, Antero de Quental, Alexandre

da Conceição, E. A. Vidal, Alves de Morais,

Alberto Teles, Francisco Gomes de Amorim, Luís

Vidart, Gomes Leal, Luís de Andrade, Amélia

Janny, Francisco de Almeida, Camilo Castelo

Branco, Augusto Sarmento, Maria Amélia Vaz de

Carvalho, Santos Valente, Rui Xavier, Guilherme

de Azevedo, Henrique Mousinho e Arnaldo Braga

Formato: $18,5 \times 27,2 \mathrm{~cm}$

Periodicidade: Semanal

Preço:Trimestre ou 12 n. ${ }^{\text {os }}$ - 600 réis

1. ${ }^{\mathrm{a}}$ Série - 20 n. ${ }^{\mathrm{os}}-1.100$ réis

2. ${ }^{\mathrm{a}}$ Série -12 n. ${ }^{\mathrm{os}}-6.60$ réis

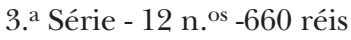

4. ${ }^{\text {a }}$ Série $-6 \mathrm{n} .{ }^{\text {os }}$ - 330 réis

Páginas: $160+96+96+48+32=432$

(engloba todas as séries)

\section{Objectivo}

«Como talvez cause estranheza o título vago deste semanário, parece-me de extrema necessidade apresentar em duas palavras o motivo que me leva a escolhê-lo de entre muitos outros, que talvez agradassem mais a obstinados amadores de palavras campanudas.

(1) A 5. Série foi impressa na Imprensa Literária. 
Todos sabemos que temos entre nós... duas escolas literárias: a dos metrificadores do ai, ou a de Lisboa; e a dos sacerdotes da ideia vaga, ou a de Coimbra. Todos nós assistimos à luta gigante que travaram entre si: era um pongo a braços com alimária de igual pujança...

Eu sou ecléctico em quase tudo, e que não pertenço a nenhuma das escolas, acho-as ambas excelentes: o belo é sempre belo, revista que formar revestir... Sou do aviso de que podem existir no mesmo campo, uns coroados de rosas, outros de barbasco, poetas individuais e vates socialistas...

Neste mísero estado de coisas, e tendo de escolher um título para este microcosmo literário, tomei-me de terrores dantescos, receando que se escolhesse título que desse a entender o mínimo pendor da minha parte para uma dessas escolas, a outra destendesse as bestas possantes, e me crivasse, novo S. Sebastião, de virotes envenenados, de setas mortíferas.

Cogitava eu pois, divagando pelos campos, que tão momentoso assunto, quando, transposta uma estéril gândara, fui dar a uns aguaçais extensos, cobertos de balsas e trémulos caniços.

A dois passos de mim agitava-se levemente à superfície da água, uma formosa folha de lotus. Uma rã, contente e feliz, entoava em cima dela um conto estridente e contínuo.

Foi uma revelação: estava escolhido o título do projectado hebdomadário: Folha. Mas folha de quê? de lotus? Não.

Para os poetas do sentimento, folha de olaia, onde entoem seus cantos maviosos. Para os poetas da ideia, folha do livro das coisas, onde revelem o verbo do absoluto.

Para os meus assinantes, folha de papel, para o uso a que esta substância é vulgarmente destinada nas sociedades modernas...» (A Folha, $1 .{ }^{a}$ Série, n. ${ }^{\circ} 1$, 1868, pp. 1-2).

\section{Conteúdo}

Aberta a todos os que nela quisessem colaborar, A Folha afirma-se, essencialmente, como um espaço de criação literária.

A colecção completa deste periódico engloba cinco séries, num total de 54 números, assim distribuídos: a primeira série com vinte números; a segunda $\mathrm{e}$ a terceira com doze números cada; a quarta com seis e a última não foi além de quatro. Todos os números têm o mesmo formato e número de páginas. 
Como refere João Penha, seu director, no texto que lhe serve de apresentação, este periódico caracteriza-se, fundamentalmente, por um certo eclectismo.

É que, em matéria literária, nela se reflecte a questão entre a forma e a ideia que tanto apaixonou a geração académica do tempo. Daí que nela se incluam poemas e traduções em linguagens várias, que vão desde os esteticistas, aos defensores do realismo social e ao baudelairianismo.

A Folha constitui, em termos literários, um campo experimental, onde se ensaiam as novas tendências da poesia.

Bibliografia: Álvaro Júlio da Costa Pimpão, «Algumas notas sobre a estética de João Penha», Biblos, vol. XV, tomo II, Coimbra, Coimbra Editora, Ld. ${ }^{a}$, 1939, pp. 519-60; Dicionário de Literatura, 4. ${ }^{\mathrm{a}}$ Ed., $2 .{ }^{\circ}$ Vol., Porto, Figueirinhas Editora, 1994, pp. 347-48 


\section{5 • FOLHA ACADÉMICA}

Hebdomadário Científico e Literário

Coimbra, Imprensa Progresso

6 Fevereiro 1886 - 3 Março 1886
Cotas:

BN: J. 775//26 A.

BGUC: -

J. 1699//7 V. J.2090 M.

BPMP: P-C-1078[8]

BMC: GHC -153

Colaboradores: Queirós Ribeiro, Acácio Guimarães, António Fogaça, Silvestre Falcão, Xavier de Carvalho, Bernardo Lucas, A. Navarro, Francisco Bastos, Augusto de Castro, Alfredo da Cunha, E. Pires de Lima, Ângelo Biester, Lomelino de Freitas, Almeida e Medeiros, Armelim Júnior e outros

Formato: 29 x $42 \mathrm{~cm}$

Periodicidade: Semanal

Preço: Não indica

Páginas: 4

\section{Objectivo}

«Se é licito ao nascer pensar na morte, seja-nos desde já permitido declarar que ao encetarmos a publicação deste jornal, em nada nos falece o ânimo para o primeiro passo que aventuramos desassombradamente com o presente número: punge-nos simplesmente a supersticiosa ideia de termos de publicar o terceiro.

... Ora, sabemo-lo de fonte limpa, a instabilidade das publicações a que nos vimos referindo, tem sido sempre resultante do pouco cuidado que se tem ligado à administração. Obviada pois esta dificuldade, como estamos convencidos haver conseguido, não parecerá de todo temerário o nosso intento; tanto mais que os redactores da Folha Académica, perfeitamente alheios a todas as questões da política militante, longe de monopolizarem as colunas do seu jornal, se esforçarão ao contrário, em torná-lo, para documento fiel da actividade mental da Academia de hoje, numa espécie de álbum, onde mais tarde, quando o destino nos separar a todos, se encontrarão ainda enlaçados os nossos nomes, como recordação feliz da aplicação proveitosa que sabemos dar às nossas curtas horas vagas do estudo.

Nada pois nos parece haver de audacioso na empreza a que nos abalançamos, não obstante a Folha Académica se não delimitar exclusivamente a um 
ou outro ramo de literatura, mas dispôr-se a abranger todas as manifestações intelectuais, desde a crónica ligeira e fugidia, ao meditado artigo de ciência. Só assim poderemos, na verdade, atingir nitidamente o fim, aliás modesto a que nos propomos, (Folha Académica, n. ${ }^{\circ}$ 1, Coimbra, 6 de Fevereiro de 1886, p. 1, cols 1 e 2).

\section{Conteúdo}

Ao longo dos seus três números, a estrutura interna de Folha Académica é sensivelmente a mesma. A primeira página é dedicada, quase e exclusivamente, a uma «Crónica» sobre Coimbra e a Academia. É que, por motivos vários, os redactores de Folha Académica reconhecem que «se há terra que mais se preste para crónicas... - é Coimbra» (n. ${ }^{\circ}$ 1, p. 1, col. 3). Não admira, por isso, o lugar privilegiado que estes textos ocupam no contexto geral do periódico. Aqui se abordam questões e acontecimentos vários: praxe académica, liberdade de aprender, métodos e organização dos estudos, boémia cultural, comícios e assembleias.

Nas outras páginas seguem-se um conjunto de textos e rubricas várias, onde se identificam as seguintes questões.

- Portugal e o romantismo

- Descobrimentos portugueses: a costa ocidental africana

- Questão social: uma questão de direito

Completam este periódico: «Cartas de Paris», onde Xavier de Carvalho nos dá notícias da capital francesa (Comuna de Paris, os cafés parisienses e a vida cultural - obra de Zola e o realismo); textos literários: excertos de livros inéditos, poesia, contos e "poemetos em prosa»; «O romance geográfico», onde Lomelino de Freitas nos fala da carreira literária de Júlio Verne e do processo acessível pelo qual a editora David Corazzi vende as suas obras; na secção «Bibliografia» anunciam-se e tecem-se breves considerações sobre as publicações recebidas. 


\section{6 • FOLHA LITERÁRIA}

Coimbra, Tip. Santos e Silva

8 Maio 1882
Cotas:

BN: J. 338//14 P.

BGUC: -

BPMP: -

BMC: GHC -20/10

Director: Eugénio de Castro

Colaboradores: Aires de Castro e Almeida, Alexandre da Conceição, Pinheiro Chagas, Joaquim Martins de Carvalho, Trindade Coelho, Alfredo Costa, A. de Matos Magalhães

Formato: 14 x $24 \mathrm{~cm}$

Periodicidade: Não indica

Preço: Não indica

Páginas: 4

\section{Objectivo}

"A redacção da Folha Literária julga praticar um acto de civismo, tão simpático, como espontâneo, dedicando o seu primeiro número, à memória do primeiro estadista português - o Marquês de Pombal.

Neste mesmo momento, a imprensa portuguesa levantando um brado eloquente e atlético, que ribomba por entre a escuridão dos séculos, saúda com energia e com calor, a memória de Sebastião José de Carvalho.

Porém, uma outra voz hodionda como o crime e negra como a morte levanta os ecos da hipocrisia, por entre a ovação entusiástica que cabe ao Marquês, e sustentando uns caprichos miseráveis e umas doutrinas falsas e beatas, arremessa o facho da ignomínia ao primeiro Conde de Oeiras. E essa classe (com respeitáveis excepções)... é - o clero hipócrita e o fanatismo. Não vamos adiante... Tachemos aqui um viva grandioso à memória do Marquês de Pombal e calquemos aos pés as vis aspirações dos hipócritas que nesta ocasião de civismo, fazem tarjar de preto, os orgãos religiosos de que fazem parte» (Folha Literária, n. ${ }^{\circ} 1$, p. 1).

\section{Conteúdo}

Trata-se de um pequeno periódico, número único, que dedica todas as suas páginas à celebração da memória do Marquês de Pombal, no primeiro centenário da sua morte. 
De salientar, com o título «Autógrafos», os retratos que, em poucas palavras, várias personalidades nos fazem do Marquês de Pombal. 


\section{7 • O FORMIGÃO}

Orgão dos ditos

Coimbra,Tipografia Formigão ${ }^{(1)}$

Dezembro 1892 - 7 Fevereiro $1893^{(2)}$
Cotas:

BN: -

BGUC: -

BPMP: -

BMC: GHC $-20 / 10$

Redactor-Chefe: Gustavo Santiago; José Gusmão

Formato: $19,2 \times 26,5 \mathrm{~cm}^{(3)}$

Periodicidade: Não indica

Preço: Trimestre - $\$ 075$ réis ${ }^{(4)}$

Páginas: 4

\section{Objectivo}

«Recolhido a voluntária obscuridade de redactor - chefe de $O$ Formigão, de que nunca desejara sair - não julguei ser um dia forçado a vir a público para desafrontar calúnias ou repelir afrontas.

Ingénuo que sempre fui, eu cheguei mesmo acreditar não coubessem tão ridículas infâmias nos estreitos limites de uma perfeitura.

E dessa crença sem outras bases que não as da camaradagem, as do coleguismo próprio de rapazes dignos, educados e que se prezam - o modo franco e leal com que até hoje me tenho apresentado a todos, o não resguardo de certas conveniências, a revelação de certos segredos inerentes ao cargo de que me via investido. Era a confiança - característica da mocidade; a amizade - distintivo grandioso dos que conhecem nestas casas, longe das famílias, e visando um único objectivo - a ciência.

(1) À semelhança do que aconteceu com outras, esta tipografia nunca existiu. Este jornal foi, possivelmente, impresso na Tipografia do Seminário (Cfr. O Conimbricense, 61. ${ }^{\circ}$ Ano, n. ${ }^{\circ} 6231$, de 11 de Julho de 1908 , p. 3, cols. 4 e 5).

(2) Cfr. Carneiro da Silva, Ob. cit., p. 67.

(3) Estas dimensões referem-se ao n. ${ }^{\circ}$ 5, de 7 de Fevereiro de 1893.

(4) Calculado, nos termos da declaração feita por Gustavo Santiago, em o n. ${ }^{\circ} 5$, de 7 de Fevereiro de 1893. 
E assim crente, eu encetei a publicação deste jornalzinho, mais como incentivo a colegas menos corajosos para as lutas da pena, que descobrindo na empresa meios menos decentes...

E agora que, sem ideia preconcebida «O Formigão» - simples e inofensivo jornal literário - ocasionou tão desagradável incidente... - só me resta agradecer a quantos me auxiliaram na sua manutenção, participando, ao mesmo tempo, o seu desaparecimento com este número...

Os senhores assinantes de três meses serão reembolsados de réis $\$ 050$ (cinquenta réis), visto termos dado jornal durante um mês...» (O Formigão, n. ${ }^{\circ} 5$, p. 1).

\section{Conteúdo}

Segundo informações colhidas em Carneiro da Silva (Ob. cit., p. 67), deste periódico publicaram-se quatro números copiografados, ostentando o primeiro a data de Dezembro de 1892 e o quarto a data de 29 de Janeiro de 1893. Segundo este estudioso das questões coimbrãs, publicou-se ainda um quinto número, impresso, com a data de 7 de Fevereiro de 1893, do qual existe um exemplar na Biblioteca Municipal de Coimbra.

Por sua vez, Pinto Loureiro, director que foi desta biblioteca, fala-nos, para além dos quatro números copiografados, de «mais dois impressos» (Ob. cit., p. 33, col. 1).

Dos jornais copiografados não encontramos qualquer exemplar.

Pela leitura do n. ${ }^{\circ} 5$, sabemos tratar-se de um jornal bastante modesto, redigido por alunos do Seminário, e onde o seu redactor-chefe, no artigo «Creado de redacção", nos esclarece das razões que o levaram a terminar com o jornal. Por aqui sabemos, igualmente, que se trata de um periódico de carácter, essencialmente, literário e que tinha como objectivo fundamental estimular aqueles alunos mais tímidos, mas que gostassem de escrever, a fazê-lo.

Para além de pequenos textos literários a existência de uma secção de «Passatempo", com charadas e logogrifos. 


\section{8・ O FÓSFORO}

Publicação Quinzenal, Literária, Noticiosa e Crítica

Coimbra, Imprensa Literária

15 Novembro 1860 - 30 Maio 1861

Redactores: António Bernardino Cerqueira Lobo, Francisco da Fonseca, Eugénio de Barros, Rodrigo Augusto Veloso, Alberto Sampaio, A. Teles, Antero de Quental, Castelo-Branco, Germano Vieira Meireles, Raimundo Capela, Santos Valente

Colaboradores: A. L. T. Crespo, A. J. A. de Andrade, José M. da Costa Seixas, João de Deus, J. de Pinto Abranches, José Leite Monteiro, A. Galvão

Formato: $15,5 \times 21,5 \mathrm{~cm}$

Periodicidade: Quinzenal

Preço: Coimbra - Trimestre - 300 réis • Avulso - 50 réis

Páginas: 8 - 12
Cotas:

BN: J. 5691//3 B.; P.P. $16910 \mathrm{~V}$; P.P. $24345 \mathrm{~V}$.

BGUC: -

BPMP: -

BMC: GHC-19/1

\section{Objectivo}

"A luz quase a extinguir-se - quer ainda o seu esplendor, e sobe e expande-se em procura da vida que lhe falta.

Mas o seu brilho inesperado indica o seu último lampejo.

Como a luz febricitante de existência e vigor - acabam todos os projectos arrojados, que pretendem alargar-se num âmbito pequeno.

E se o desejo da vida obscura e proveitosa não carecer dos estos incendiários da glória e do renome, mas for sempre com a consciência de que faz bem, e com a certeza de que não pode sequer assombrar «tantas luzes» que por ali fulguram - não será essa vida mais feliz, menos odiada e mais duradoira?. De certo.

A vida do nosso jornal é esta, e o nosso jornal se quizer opôr-se ao de profundis dos ambiciosos que se precipitam há-de ser sempre Fósforo.

E porquê? Porque há-de ter uma luz ténue, ainda que formosa, do brilho que não deslumbra, porque nos há-de queimar, como tantas luminárias da nossa época, espalhadas por esse mundo, onde se ascendem e se queimam mutuamente; porque há-de enfim aparecer na terra da promissão como o pirilampo em noite de luar... 
Pois o nosso jornal - no meio de tantas publicações aprimoradas que por aí tem empanado muitas luzes mortiças - há-de voejar assim.

Se alguém pretender esmagar - o vagalume de nossa mesquinha publicação - lembre-se de que lhe ficará entre os dedos o rasto fosfórico do seu último luzimento. E depois não tenha remorsos, percebe?

Quero, para escrever alguma coisa conceituosamente, recordar o dito engraçado de um amigo!. "Não imaginem, que eu vá crivar palavras, ajoeirar termos, para vir tramar com eles uns periodozinhos asados a susceptibilidades linguísticas, e paladares pipieiros; enganam-se redondamente: o que me lembra é o que me sai da pena...».

E é assim. De que serve amofinar a paciência de quem lê, pespegando-lhe um estilo humoral meia dúzia de graciosas pieguices, que a maior parte das vezes raspam no ouvido, para descambarem depois em zumbidos que adormenta?». (n. ${ }^{\circ} 1,1860$, p. 2).

«Entra o Fósforo no seu segundo trimestre... é com mais vida que nunca, que ele ousa apresentar-se ao público. Acolhê-lo-á ele com a mesma benevolência? Continuar-lhe-á a sua protecção? É nossa fé que sim, e o penhor seguro ei-lo nesses nomes esperançosos que vieram inscrever-se no número dos seus redactores...

De mais, como muito bem disse o Sr. Bruschy na Revista Académica: «De qualquer formato, ou de qualquer modo que seja o método da publicação, um jornal literário é sempre uma obra boa; é derramar a instrução entre muitas pessoas, que somente deste modo a podem obter... E que boa obra é não privar tanta gente deste bem» (n. ${ }^{\circ} 7,1861$, p. 53).

\section{Conteúdo}

O Fósforo é uma pequena publicação literária, noticiosa e crítica que pretende divulgar instrução e cultura ou, como diz o seu cronista, contribuir para «a realização de uma ideia altamente progressiva e civilizadora» (n. ${ }^{\circ} 6$, p. 51, col. 1).

Quanto ao formato, mantém o mesmo ao longo dos seus doze números. O número de páginas é, também, igual em todos os números, oito, excepto no n. ${ }^{\circ} 6$, que tem doze. De assinalar ainda que a primeira página do n. ${ }^{\circ} 5$ se en- 
contra circunscrita por um rectângulo de cor preta, testemunhando, assim, o sentimento de luto pelo falecimento do estudante Alexandre Sousa Pinto.

Com uma primeira página indefinida, seguem-se, nas outras, um conjunto de artigos e rubricas várias. A existência, nos fins de cada número, de uma secção permanente intitulada "Crónica/Revista", da autoria de Rodrigo Veloso, espaço reservado a um conjunto de notícias, acontecimentos e apreciações de assuntos vários, não só do que de mais importante se vai passando em Coimbra, mas também em outras partes do país, de quinze em quinze dias.

Para além de um espaço de criação literária, com textos em prosa e em verso (por curiosidade, referimos, aqui, a poesia intitulada «Portugal. Contra El-Rei de Castela», por, em nota, estar a indicação de que esta poesia estava inédita há duzentos anos, pois havia sido composta aquando da aclamação de D. João IV), lugar, também, para alguns ensaios no domínio da literatura e ainda recensões a obras dadas à estampa como Meditações Poéticas de Lamartine e Recreações Poéticas de F. Castro Freire.

Com o intuito de ilustrar e divulgar cultura, em pequenos artigos que, por vezes, se repartem por mais que um número, abordam-se temáticas que, na globalidade, podemos identificar como:

- Política: reflexões sobre monarquia, democracia, aristocracia, teocracia, noção de povo, soberania popular, sufrágio universal, liberdade, igualdade e fraternidade (Citam-se Estudos sobre a reforma em Portugal de Henriques Nogueira), concluindo-se que «o governo duma nação deve ser estabelecido analiticamente, isto é, de baixo para cima, escutando a natureza e necessidades da humanidade» (n. ${ }^{\circ}$ 4, p. 27, col. 1); direitos individuais e de terceiros.

- Economia: origens e vantagens da Economia Política

- História: da autoria de Alberto Sampaio o artigo «Esboço Histórico», sobre a decadência de Portugal, nos finais do século XVI; em «A prosa do casamento. Prologomenos», R. Capela alude à ida e vinda de portugueses do Brasil e maneira como se apresentam.

- Filosofia: reflexões também sobre a razão «que torna o homem a mais nobre e a mais excelente de todas as criaturas» (n. ${ }^{\circ}$ 6, p. 44, col. 2). Cita-se Bosnet e Bayle. Termina-se, concluindo que Deus «deu-nos a razão para nosso bem e utilidade; se lhe damos mau uso, a culpa é nossa» (p. 45, col. 2). 


\section{9・FOTOGRAFIAS}

$\begin{array}{ll}\text { Crónica humorística sobre assuntos sérios } & \text { Cotas: } \\ \text { Coimbra, Livraria Popular Editora } & \text { BN: - } \\ 1875 & \text { BGUC: - } \\ & \text { BPMP: - } \\ & \text { BMC: A.M. -257 }\end{array}$

Director: Sérgio de Castro

Formato: 13 x $20,5 \mathrm{~cm}$

Periodicidade: Não indica

Preço: Não indica

Páginas: 79

\section{Objectivo}

«Ah, leitor, amigo - tratava-se de uma coisa séria, razoavelmente séria, digna até da tua seriedade impostora, e para a qual eu peço dois momentos da tua preciosa atenção.

E olha lá, leitor, antes de mais. Eu sei de uns certos sujeitos, homens do nosso tempo, que atravessando as eras e os séculos, foram ter com o sábio Salomão...

Ora, segundo os tais sujeitos, o que eu hoje digo, por exemplo, já foi dito por outros, e por consequência... ovos moles. Este doce, de que talvez gostes muito, o que se vende em Aveiro, quer dizer que eu devia ficar calado, e seguilos... aos tais sujeitos!

Não estou resolvido a tal caminhada, canseira para que não chegam os meus pulmões algum tempo arruinados.

Se tu és desses, leitor, homem aborrecido, tipo peninsular, e, mais do que peninsular, português-brasileiro: preguiçoso, indolente, ignorante... atende, que eu quero ilucidar-te sobre um objecto grave, embora depois lances dois sorrisos gratuitos e duas palavras de efeito, que são o castigo do teu orgulho requintado. Se não és dos tais, atende também, porque quero merecer de ti um abraço... eu aborreço de morte todos os parasitas, todos os ociosos e vadios, verdadeiros pelintras da sociedade. Se o meu trabalho é inglório, é útil, e contento-me com o conceito dos versos do fabulista; mas no meio deste trabalho conservo intactas certas coisas muito dignas, que os tais que nós conhecemos vão entreter nos aplausos do can-can. 
Deixa-os, deixa-os, e vem comigo. Se julgarem lisonja própria o que escrevi, respondo-lhes que há muito assentei na carteira como aforismo as poucas linhas que seguem» (Fotografias, p.p. 6-8).

\section{Conteúdo}

Fotografias é um simples e modesto periódico, que não foi além do primeiro número e que o seu director dedicou a Ramalho Ortigão. Utilizando o humor, é seu objectivo denunciar situações e personalidades da vida e sociedade portuguesa. É o caso de um tal Fonseca que é cauteleiro/cambista, «má coisa, mau ofício, como tentaremos mostrar com a graça e auxílio dos factos, que nos fornecerão as provas de que havemos mister» (p. 12).

O mesmo com o jogo e o jogador, nomeadamente o de lotaria, que «tornou-se um sujeito fantasioso, impossível neste século de positivismo e de realidade» (p. 28).

Críticas também para as corridas de cavalos, porque se dão «prémios aos cavalos em quanto se paga 239 réis diários ao professor primário» (p. 58).

Críticas, a diferentes níveis, também para o Padre Sena Freitas. Ao nível literário, por exemplo, e tendo em conta o seu livro A tenda do mestre Lucas, julga-se o criador de «o romance cristão». Então, em Fotografias escreve-se: «Se queres edificar-te, não compres o livro; se queres amar o próximo, idem, leitor: agora, se queres insultar a Providência e desprezar a humanidade, compra-o, e lê» (p. 49).

Críticas para a sociedade portuguesa, em geral, onde o nobre, para se adaptar aos novos tempos, se procura aburguesar e o burguês, ansioso de títulos, tenta nobilitar-se. Daí que se afirme: «Em Portugal a velha fidalguia, pouco misturada com relações burguesas, começou a efeminar-se, e o barão-mercieiro e o fanqueiro-visconde principiaram a engordar sem limites, insolentemente» (p. 66).

Defende-se, finalmente, o dramaturgo António Ennes das críticas que muitos fazem à sua obra, Os Lazaristas. Distinguindo entre os críticos de sacristia e os críticos literários, afirma-se que António Ennes é «escritor de muito talento e consciência sã, publicou um drama contrário à hipocrisia, ao fanatismo e ao negócio da água benta» (p. 75). 


\title{
$60 \bullet$ O GAIATO
}

\author{
Revista Literária e Recreativa ${ }^{(1)} \quad$ Cotas: \\ Coimbra, [s.l.] \\ 9 Fevereiro 1897 - 21 Fevereiro 1897 \\ BN: J. $984 / / 37$ P. \\ BGUC: - \\ BPMP: IX - 2 - 124 \\ BMC: GHC -4
}

Director: P. A. N. Freire de Andrade

Administrador: Luís J. Brousse

Redactor: J. C. de Noronha

Colaboradores: J. Tomás, Mateus Júnior, Ernesto

d'A. Henriques, J. Augusto Bastos.

Alguns colaboradores usam pseudónimos como:

Gambyses, Latim da Silva, Ziul e Zé Pinóia

Formato: 22,5 x $32 \mathrm{~cm}$

Periodicidade: Trimensal

Preço: Trimestre - 200 réis

Páginas: 4

\section{Objectivo}

«Nós, um grupo de rapazes sem instrução, inexperientes na arte da literatura, apresentamos em público a nossa pequena revista cognominada $O$ Gaiato que tem por fim desenvolver-nos e instruir-nos, para que nos saibamos apresentar na sociedade.

Esta nossa pequena revista não tem por fim criticar, como os nossos leitores vão julgar à primeira vista, nem o fim é criticar, porque não temos de quê, e nem mesmo nos acharmos habilitados para o fazer.

Mas, meus queridos leitores, como a literatura tem aumentado dia a dia não só no nosso país como também nos países estrangeiros, justo e desculpável é que nós ainda que vacilantes ensaiemos as primeiras passadas na esperança de lhe virmos a atingir o maior desenvolvimento, esperando a vossa benevolência.

Não queremos nós dizer com isto que somos umas inteligências que possamos atingir de um momento para o outro, esse grau de desenvolvimento; mas empregaremos os esforços para alcançar parte dele. Avante - Literatura! Avante o Gaiato» (O Gaiato, n. ${ }^{\circ}$ 1, Coimbra, 9 de Fevereiro de 1897, p. 1, col. 1 e 2).

(1) O último número tem como subtítulo: Revista Literária, Humorística e Recreativa. 


\section{Conteúdo}

Trata-se de uma pequena publicação de carácter literário e recreativo de alunos do liceu, de que se publicaram apenas dois números, tendo o último uma pequena alteração no subtítulo.

Sem interesse de maior, para além de pequenos textos literários e alguma poesia, fazem-se críticas a outras publicações periódicas, nomeadamente à revista Gondola e ao jornal Flor do Mondego, a quem chamam de «jornaleco ridículo» (n. ${ }^{\circ}$, p. 1, col. 3).

Aborda ainda assuntos escolares, nomeadamente o modo como são convocadas e como decorrem as reuniões dos estudantes no Liceu.

No âmbito do campo recreativo, a existência de uma «secção charadística».

Completam este jornal algumas pequenas notícias, um folhetim e anúncios de publicações. 


\section{1 - A GAITA DE FOLES}

Diário em prosa por uma sociedade

de poetas anónimos

Coimbra, [s.l.]

6 Maio $1871^{(1)}$

Director: João Penha ${ }^{(1)}$

Formato: 14 x $20 \mathrm{~cm}$

Periodicidade: Não indica

Preço: (2)

Páginas: Não indica
Cotas:

BN: -

BGUC: -

BPMP: -

BMC: GHC -4

\section{Objectivo}

Não indica

\section{Conteúdo}

Trata-se de uma «folha» litografada de que saiu apenas um número. Apesar de o subtítulo nos dizer tratar-se de um "Diário em prosa», o facto é que esta «folha» está redigida em verso. Envolvendo uma página, aqui se inscreve uma poesia, com dez versos, intitulada «O Fantasma», da qual se reproduzem os seguintes:

«O Diniz é mais sombrio

$\mathrm{Na}$ tristeza que o reveste

Do que um fúnebre cipreste

Do cemitério da pia,

Vede-lhe o aspecto doentio!

(1) Segundo informações colhidas em A. Carneiro da Silva, ob.cit., p. 68, A Gaita de Foles é uma «folha» extraordinariamente rara. Veja-se a este propósito a informação referida por Álvaro Júlio da Costa Pimpão, «Algumas notas sobre a estética de João Penha», Biblos, vol. XV, tomo II, Coimbra, Coimbra Editora, Ld a, 1939, p. 552.

(2) No próprio periódico lê-se o seguinte: «O preço deste jornal é meia dúzia de asneiras por mês. O mesmo de Zabumba». 
Revela-se aqui um tipo de cultura, a que, dadas as suas características e por analogia com a literatura, podemos chamar de escárnio e maldizer. Trata-se de uma cultura tipicamente estudantil, de feição satírica e que se caracteriza por uma certa irreverência e sentido de humor, sobretudo em relação à comunidade envolvente. É, por isso, natural que a Universidade, professores, colegas e até figuras da sociedade civil coimbrã sejam os alvos preferidos por este tipo de crítica, no intuito de denunciar determinadas realidades, mas sempre com o propósito, não de ferir, fosse quem fosse, mas de divertir e moralizar. É bem possível que esse Diniz de que os versos falam, possa ser, por exemplo, um colega do autor. 


\section{2・GÔNDOLA}

Revista Dezenal, Literária e Recreativa ${ }^{(1)}$

Coimbra, Tip. e Lit. Minerva Central

6 Janeiro 1897 - Agosto 1897
Cotas:

BN: J. 1648//14 V.;

BGUC: J. $2460 / / 24 \mathrm{~V}$.

BPMP: -

BMC: GHC -4

Director: Boaventura Aguiar

Administrador: E. M. da Fonseca

Redactores: J. Marques dos Santos, A. X. Alves dos Santos, Carmo Braga, Bento de Lencastre

Secretário de Redacção: J. Carlos de Aguiar

Colaboradores: João Marques dos Santos, J. Xavier Pereira, José Tomás da Fonseca, J. Gomes, António P. de Sousa, J. Lebre, Cândido de Figueiredo, Vilela Passos, Gonçalves Cerejeira, Júlio de Lemos, José Lopes de Oliveira, Alfredo Serrano, Rodrigo Solano, Luís Guimarães, filho, Ana de Castro Osório, Laura de Pratt

Formato(s): 22 x $32 \mathrm{~cm} \bullet 14$ x $21 \mathrm{~cm} \bullet 12$ x $18 \mathrm{~cm}$

Periodicidade: Dezenal/Bi-mensal (2)

Preço: Trimestre -120 réis $\bullet$ Avulso -30 e 40 réis ${ }^{(3)}$

Páginas: 120

\section{Objectivo}

«Confiados na protecção do público sensato, que já por mais de uma vez tem dado inequívocas provas da sua benevolência para connosco, intentámos a publicação desta pequeníssima e muito modesta revista, cujo primeiro número tomamos a liberdade de apresentar-lhe.

Sem aspirações elevadas, e conhecendo de sobejo a deficiência de dotes intelectuais, não vimos apresentar, nem poderíamos fazê-lo, um programa pomposo, repleto de grandes projectos; limitamo-nos unicamente a indicar o motivo

(1) Do n. 5 em diante, somente, Revista Literária. O último n. ${ }^{\circ}$ não tem subtítulo.

(2) Em nota, «Aos nossos assinantes», lê-se a seguinte informação: Gondola passa a ser «bi-mensal, sem dias determinados de saída» (n. ${ }^{\circ}$ 6, 24 de Março de 1897, p. 32).

(3) Os 40 réis é o preço do último número. 
por que empreendemos a publicação desta revista, e a explicar breve, mas concisamente o fim que desejamos atingir.

Cumpre-nos participar... que não militamos, nem tão pouco militaremos, em qualquer partido ou facção política; a nossa pouca idade, e por consequência a falta de força para sustentarmos com firmeza um ideal, e também o nosso modo de pensar, inibem-nos completamente de proceder de outra maneira.

Posto isto, e atendendo a que foi o desejo de nos instruirmos que nos levou a tentar a publicação desta revistazinha, consistirá o programa em facilitar a cultivação das nossas faculdades intelectuais, em promover a dos nossos estimados colaboradores, e finalmente em incitar todos os nossos leitores à cultura das letras, programa este que pelo seu fim nobre e desinteressado, merecerá certamente a protecção e simpatia de todos os que nos lerem, favor que antecipadamente agradecemos, convictos da sua realização» (Gondola, n. . 1, Coimbra, 6 de Janeiro de 1897, p. 1, cols. 1 e 2).

\section{Conteúdo}

Gondola é uma pequena revista de carácter literário e recreativo de que se publicaram apenas dez números.

A estrutura desta revista não foi sempre a mesma, quer quando temos em conta o seu formato, o número de páginas, quer até o próprio subtítulo. De referir, também, que os números 6, 7 e 10 são ilustrados com retratos de Camilo Castelo Branco, em homenagem «ao grande mestre, que apesar de morto, vive na memória de todos» (n. ${ }^{\circ}$ 6, p. 17) e dos «novos» poetas, Gonçalves Cerejeira e M. Dias Nunes, respectivamente.

Com o subtítulo de «Revista Literária e Recreativa» e, depois, somente, «Revista Literária», afirma-se, naturalmente, como um espaço de criação, seja em prosa ou em verso. Aqui se dão a conhecer excertos de livros em preparação ou com saídas iminentes do prelo e de que são exemplos, entre outros, títulos como: «Amarguras», de Bento de Lencastre, «Pastoril», de Carmo Braga e «O teu beijo» do livro Noites de Paz, de José Tomás da Fonseca.

Reflectindo as vivências e influências do tempo, nestes e outros textos são evidentes os traços genéricos de uma literatura finissecular, quer ao nível de títulos e expressão literária, quer, inclusivamente, na perspectiva de representa- 
ções, filosofias e conteúdos. Se títulos como «Sol-posto», "Crespuscular» e «Murmúrios de um Cipreste» são, só por si, bastante elucidativos, já o sentido dos símbolos é claro, quando escrevem: «o firmamento representa o nosso cérebro; as estrelas que o constelam representam as ilusões fagueiras que o povoam; a luz representa o fruto das nossas locubrações intelectuais; a espécie de castiçal em que ela arde, representa as modestas revistas por nós fundadas» (n. ${ }^{\circ}$ 1, p. 4, col. 1), para, influenciados por Schopenhauer, que citam, aceitarem que «viver é sofrer».

Ainda no domínio da literatura e criação literária e para recordar a morte do autor de Campo de Flores, assinale-se o artigo «Aniversário Triste» e a poesia que Joaquim Gomes intitulou de «À morte de João de Deus».

Completa-se esta publicação com uma secção, que durou muito pouco tempo, «P’ra Gondola», que é uma espécie de crónica, onde se divulgam notícias diversas; com «charadas»; anúncios de publicações e os habituais folhetins. 


\section{3 • GRÉMIO ALENTEJANO}

Coimbra, Imprensa da Universidade

10 Outubro 1861 - 8 Maio 1862

Responsável: Não indica ${ }^{(1)}$

Colaboradores: Luís Carlos Simões Ferreira, Augusto Saraiva de Carvalho, J. Simões Ferreira, António Francisco Barata, João Maria Batista Calisto, José António Santos Silva, R. de Morais Soares, M. Quaresma, Luís Augusto Pimentel e outros como, por exemplo, Antero de Quental com pseudónimo de Vasco Vasques Vasqueanes (Cfr. Carneiro da Silva, ob. cit., p. 71)

Formato: 32 x $45 \mathrm{~cm}$

Periodicidade: Semanal

Preço: Trimestre - 550 réis

Páginas: 4
Cotas:

BN: J. 494//8 M;

J. $775 / / 33 \mathrm{~A}$

BGUC: $\mathrm{B}-48-65$ - 3

BPMP: P/C/1070

BMC: GHC -152

\section{Objectivo}

«Mais um filho da civilizadora invenção do imortal Guttemberg, mais um fruto da viçosa árvore da liberdade, que, implantada no solo do nosso país e regada com o sangue de milhares de mártires, garantiu ao homem o exercício de um dos mais sagrados dos seus direitos, o de transmitir a seus irmãos o produto de suas cogitações, vai hoje ver a luz da publicidade.

... Aí vai pois o modesto Grémio Alentejano ensaiar os seus primeiros e vacilantes passos na difícil e espinhosa senda do jornalismo.

Longe da terra, cujo sol alumiou a seus olhos apenas abertos as primeiras magnificências do grande livro da natureza, cujos campos foram testemunhas de seus primeiros e inocentes folguedos..., longe finalmente da terra, que em si resume tudo o que para eles há no mundo de mais caro, os filhos da província transtagana reunidos em Coimbra, para receberem no primeiro templo científico do país o baptismo da ciência, ansiando-lhes os corações por mitigarem as saudades, que pela pátria sentiam, trataram de formar uma associação, em que,

(1) Veja-se, adiante, a nota de rodapé assinalada com asterisco. 
a par da instrução e recreio, pudessem estreitar-se cada vez mais intimamente os laços de fraternidade, que entre si devem ligar os filhos de uma mesma pátria.

As futuras prosperidades do Alentejo, e os meios de as conseguir pelo aperfeiçoamento das culturas, pelo melhoramento das outras indústrias, pelo derramamento da instrucção e moralização por todas as classes, pela colonização dos terrenos incultos, pela abertura de vias de comunicação, pelo estabelecimento de bancos rurais e caixas económicas, finalmente pela aplicação das suas teorias da economia social e administração pública; - eis os objectos das conversações e das discussões de todos os dias, e de todos os instantes, em que o descanso de nossos trabalhos escolares nos permitia que naquele santuário da fraternidade nos reunissemos.

Um periódico que advogasse todos estes interesses, um periódico que fosse o pregoeiro destas teorias e da sua aplicação à nossa província...

Tal foi o princípio de onde nasceu o Grémio Alentejano, o pensamento que presidiu à sua criação.

É um brado de amor e saudade, que enviamos à terra que nos viu nascer; advogar em tudo, e por todos os meios legítimos, os seus verdadeiros interesses é o mote da nossa bandeira...

Mas não é só, ensinando e recomendando as boas teorias económicas e administrativas, pedindo e fazendo sentir às câmaras legislativas e ao governo a necessidade de leis e regulamentos, tendentes à boa e útil aplicação daquelas teorias, que julgamos ser úteis à pátria...

Vai pois, modesto periódico, e que o génio do progresso te guie!... caminha, que te acompanharão as bençãos e os votos de todas as almas progressistas, que te virem afrontando os temerosos escolhos da opinião pública para cumprires a tua sagrada missão! (Grémio Alentejano, n. ${ }^{\circ} 1,10$ de Outubro de 1861 , p. 1, cols. 1, 2 e 3).

... «São já passados mais de cinco meses depois que começou a amadurecer à luz da publicidade este acanhado fruto de nosso interesse... e uma voz interior nos repete constantemente ao espírito esta pergunta: Como tendes desempenhado o vosso compromisso? Que tendes feito em prol da terra que vos viu nascer e que tanto amais?

Que alguma coisa temos feito, nos diz a consciência... Mas teremos nós feito tudo o que ainda com os fracos recursos de que podemos dispor, poderíamos fazer? Em que nos pese, temos de confessar que não! Efectivamente, para que em consciência e cabalmente cumprissemos o programa do nosso periódico, 
seria mister que arcássemos com o governo e com os poderes públicos, e em nome da prosperidade da nossa província, lhes exprobrássemos a sua incúria... batessemos qualquer medida administrativa contrária aqueles interesses seria mister que desassom-bradamente analisássemos o proceder das autoridades; seria mister... que este periódico... invadisse o campo da política.

Mas isto não o podíamos nós fazer, enquanto para este fim nos não habilitássemos legalmente, satisfazendo as condições que a lei exige.

É este novo carácter do nosso periódico, que hoje anunciamos a nossos leitores. Não se pense porém que... nos vamos alistar debaixo das bandeiras de qualquer dessas facções políticas... A nossa política é de princípios, que não a de nomes próprios.

Queremos a liberdade, e a igualdade perante a lei; queremos a manutenção da ordem pública e o respeito da prosperidade do cidadão; queremos o derramamento da instrução e da moralização pelo povo, queremos a economia possível nas despesas do estado, a abertura das estradas ordinárias e dos caminhos-de-ferro, que sejam compatíveis com essa economia e com as forças da nação, e a liberdade de comércio..., queremos... que o governo... repila qualquer tentativa de reacção religiosa tendente a predominar na marcha das coisas públicas, encaminhando-as no sentido do obscurantismo. Eis o nosso credo político...

Na nova fase, por que vamos passar, contamos com a continuação do valioso apoio dos nossos patrícios» (Grémio Alentejano, n. ${ }^{\circ} 22,6$ de Março de 1862, p. 1, cols. 1, 2 e 3).

\section{Conteúdo}

Este interessante periódico pretende, fundamentalmente, contribuir para o desenvolvimento moral e material da província do Alentejo.

Se, inicialmente, o discurso proferido é relativamente comedido para com os poderes públicos, a partir do n. ${ }^{\circ} 22$, Março de 1862, há uma mudança nítida de estratégia. Interrogando-se sobre o caminho percorrido e os objectivos alcançados, os seus responsáveis entendem que devem passar a actuar mais, mas no campo político. Ganhando uma maior feição política, o discurso de protesto torna-se, agora, mais evidente e mais crítico, não só ao nível dos artigos de fundo, mas também dos próprios correspondentes. Numa crítica aos políticos, o correspondente de Lisboa escrevia na sua crónica: «a maldita política pessoal, 
que tantos males nos tem causado, e há-de acabar por perder este desgraçado país» (n. ${ }^{\circ}$ 24, p. 3, col. 2).

A estrutura de Grémio Alentejano é sensivelmente a mesma ao longo dos seus trinta e um números. Na colecção por nós consultada, na B.M.C., onde faltam os nos. 27 e 29, apenas o n. ${ }^{\circ} 13$ apresenta, ao nível do formato, uma pequena diminuição, no sentido do cumprimento.

Também a primeira página do n. ${ }^{\circ} 6$ está envolta num rectângulo de cor preta, marcando assim o sentimento de luto pelo falecimento do rei D. Pedro V.

Uma boa parte da primeira página é, normalmente, dedicada ao artigo de fundo, que raramente ostenta qualquer título. Seguem-se, depois, um conjunto de textos, de artigos e rubricas várias. De salientar a existência da secção permanente de «Noticiário», espaço relativamente considerável nas últimas páginas, onde se divulgam as mais diversas e variadas notícias (da corte, de Coimbra, da Universidade, várias localidades do Alentejo, feiras, teatro, publicações, eleições no Grémio Alentejano ${ }^{(*)}$, Academia Dramática, projectos de lei, preços de produtos em diferentes mercados, Sociedade Filantrópica, câmaras, festividades, falecimentos, etc., etc); secções que tiveram apenas carácter temporário como: «Boletim Estrangeiro», onde se fala e tecem breves considerações sobre o que vai pelo mundo, com muitas referências de imprensa estrangeira; "Parte Oficial», com decisões dos Ministérios dos Negócios do Reino, da Guerra, Negócios Estrangeiros e Fazenda. Aqui se transcreve também a Acta do Conselho de Estado, aquando do falecimento de D. Pedro V; «Crónica Agrícola», onde se dão esclarecimentos e se explanam questões várias sobre a matéria; «Publicações Literárias», geralmente na última página, um pequeno espaço onde se anunciam livros e outras obras dadas à estampa; «Crónica de Lisboa/Interior. Correspondência particular de Lisboa», com notícias várias da capital, problemas abordados pela imprensa lisboeta, teatro e lutas político-partidárias; "Correspondência dos Açores», com notícias e informações do arquipélago e cujo intuito é, segundo o seu autor, «narrar os sucessos contemporâneos, observar atentamente os acontecimentos, julgá-los com frieza e pronunciar a minha sentença” (n. ${ }^{\circ}$ 13, p. 2, col. 4). Por motivos que se desconhecem, esta coluna teve uma vida bastante efémera. Aparecem-nos, também, com alguma frequên-

(*) Nos n.os 11 e 21, de 19 de Dezembro de 1861 e 27 de Fevereiro de 1862, respectivamente, dão-se a conhecer os nomes dos corpos gerentes do Grémio Alentejano. 
cia, «Correspondência/Comunicados», mas, fundamentalmente, aquando da morte de D. Pedro V, para se relatar o modo como decorreram as exéquias fúnebres celebradas em sua honra, nesta ou naquela localidade.

Nos diferentes textos e artigos é possível identificar as seguintes temáticas e questões:

- Educação/Instrução: Importância da educação que «é a base fundamental da felicidade humana» (n. ${ }^{\circ} 15$, p. 1, col. 2); defesa da instrução pública, gratuita e obrigatória, porque é «a primeira e mais palpitante necessidade» (n. ${ }^{\circ} 2$, p. 1, col. 2); uma educação para a mulher; vantagens da instrução primária; alguns problemas com este grau de ensino, nomeadamente ao nível do Alentejo (falta de professores, mas que nas aldeias podem ser substituídos pelo padre, sendo, porém, necessário que este «seja instruído e moralizado, e não ignorante, turbulento e ambicioso» (n. ${ }^{\circ}$ 2, p. 1, col. 4), o baixo vencimento dos professores, a sua falta de preparação e a pouca sensibilidade das pessoas do campo para frequentarem as escolas); críticas muito fortes ao facto de se entregar o ensino e a direcção do Seminário de Cernache aos frades lazaristas, porque assim só sairão «clérigos intolerantes e ultramontanos» (n. ${ }^{\circ} 14$, p. 2, col. 1); críticas idênticas para as irmãs da Caridade Francesa e para os Jesuítas «que ultrajam o altar e a cruz» (n. ${ }^{\circ} 28$, p. 1, col. 4); defesa de uma educação informal (o exemplo da Filarmónica de Niza).

- Agricultura: importância e defesa da agricultura que «é a base fundamental da felicidade das nações» (n. ${ }^{\circ} 17$, p. 1, col. 2); críticas aos governos pela falta de apoios; necessidade de estabelecimento de escolas teóricas e práticas; abertura de vias de comunicação; abertura de poços artesianos; construção de grandes reservatórios de água e sistema de drenagem; evitar a fuga de pessoas dos campos, sobretudo no Alentejo (distribuição de terras e modificações na estrutura da propriedade); construção de uma granja modelo, com vista a uma agricultura racional e para acabar com a máxima de «faço assim, porque meu pai o fazia» (n. ${ }^{\circ}$ 3, p. 1, col. 3); defesa do livre-cambismo; providências e apoios para as zonas alentejanas mais atingidas pela intempérie; considerações agronómicas sobre o concelho de Castelo de Vide; o homem e a floresta (relação do homem com a floresta, as grandes florestas na Antiguidade, dados estatísticos sobre a perda da floresta, o problema dos fogos).

- Política e Sociedade: afirmações de amor à Pátria e ao Alentejo; críticas ao comportamento dos nossos políticos, nomeadamente aos deputados que rejeitam projectos, permitindo assim o avanço da reacção, que é identificada, 
essencialmente, com o clero; a política conservadora na Europa; a indiferença dos cidadãos perante a política e a res pública: «um dos piores sintomas de desorganização social... é a indiferença da parte dos governos» (n. ${ }^{\circ}$ 26, p. 1, col. 1); defesa de grandes reformas, nomeadamente ao nível da administração - a descentralização -, porque «a descentralização é um princípio necessário para o progresso e para a segurança das liberdades pátrias» (n. ${ }^{\circ} 2$, p. 2, col. 3); o papel e importância dos municípios; a defesa do associativismo; as associações de socorros mútuos.

- Economia: necessidade e importância do conhecimento de princípios económicos; a importância da economia política; defesa da liberdade comercial; os impostos; o crédito; projecto de lei sobre crédito predial.

- História: reflexões breves sobre o $1 .^{\circ}$ de Dezembro de 1640; D. Pedro V (vida e obra, sua morte; publicação do auto de autópsia, descrição dos cortejos fúnebres, comunicados de como as povoações manifestaram os seus sentimentos pela morte do Rei); Panteón Real; Reis de Portugal e o que de mais importante fizeram; o falecimento de Passos Manuel (opiniões de Almeida Garrett e Mendes Leal).

De referir ainda neste periódico a publicação de documentos como: «Conta de receita e despesa do Asilo da Mendicidade da cidade de Coimbra desde a sua fundação, em Setembro de 1855, até 31 de Dezembro de 1861»; «Acta descritiva dos exames e mais solenidades praticadas nesta notável Vila de Montemor-o-Novo, para a distribuição dos prémios, que, em benefício da instrução popular deste reino, oferece às escolas primárias a benemérita sociedade Madrefora, de portugueses residentes no Rio de Janeiro, império do Brasil»; «Projecto de Lei sobre crédito predial» e ainda uma acta da Câmara Municipal de Vila Viçosa, a respeito de condições sanitárias.

Completa-se este periódico com alguma poesia e folhetins. 


\section{4 - A HARPA}

Jornal crítico, noticioso e literário

Coimbra, Imprensa Conimbricense

7 Novembro 1861 - 10 Abril 1862
Cotas:

BN: -

BGUC: -

BPMP: -

BMC: GHC -19/7 - S

Redactores: Francisco Augusto Martins de Carvalho e A. A. Ferreira de Sousa (1)

Colaboradores: Teófilo Braga, L. C. Simões Ferreira, J. Simões Dias, Júlio Manso Preto, Adolfo Coelho, Inácio Rodrigues da Costa Junior, A. P. de Almeida, Amélia Janny e Adolfo Trony

Formato: $16 \mathrm{x} 22 \mathrm{~cm}$

Periodicidade: Quinzenal

Preço: Gratuito

Páginas: 4

\section{Objectivo}

«Sai hoje pela primeira vez à luz da publicidade, o nosso pequeno jornal quinzenal, intitulado a Harpa.

Não foi o interesse que dele nos pudesse provir, que nos levou a publicá-lo. Entreter-nos nas horas vagas com um divertimento inocente e instrutivo, é o fim deste jornal.

E a prova é bem evidente, pois que não se recebe por ele paga alguma, mas sim o oferecemos às pessoas do nosso conhecimento e amizade.

É de esperar que os nossos leitores e amáveis leitoras, nos relevem as imen-

178 sas faltas que o nosso jornal sem dúvida há-de ter, atendendo ao pouco peritos que ainda estamos nas lides da imprensa» (A Harpa, n. ${ }^{\circ}$ 1, 7 de Novembro de 1861, p. 1).

(1) A partir do n. ${ }^{\circ}$, inclusive, o nome de Ferreira de Sousa deixa de constar. 


\section{Conteúdo}

Com um interesse muito modesto, A Harpa é um pequeníssimo jornal de carácter noticioso, literário e crítico, cujo fim principal é divertir, instruindo.

Formando uma colecção de 12 números, esta publicação mantém, do princípio ao fim, o mesmo formato e número de páginas. A primeira página do n. ${ }^{\circ} 2$ apresenta-se envolvida num rectângulo preto, em sinal de luto pela morte de $\mathrm{D}$. Pedro $\mathrm{V}$, à qual se alude num pequeno texto. Ao nível da estrutura interna, os primeiros sete números apresentam as seguintes secções: «Variedades», que é um espaço preenchido com poesia, de quem Júlio Manso Preto, em carta enviada à direcção, a agradecer a oferta do jornal, diz que «agrada pela sua simplicidade, e, sobretudo, pela candura e suavidade de sentimentos» (n. ${ }^{\circ} 4$, p. 1, col. 2); «Noticiário/Mosaico», onde se dão a conhecer notícias e informações várias e «Charadas», que vai até ao fim da publicação, com enigmas, para entretenimento. De anotar, ainda, a partir do n. ${ }^{\circ} 7$, «Diálogo entre ele e eu/Revista Dramática», espaço dedicado ao teatro.

Para além de textos descritivos, de carácter moralizante e de uma breve apreciação crítica à obra Arzila de Bernardino Pinheiro, completam este periódico um pequeno artigo, de carácter histórico, intitulado «Tosão d'Ouro», de A. P. de Almeida, sobre a ordem do mesmo nome que Filipe de Borgonha instituiu, em Bruges, em 10 de Janeiro de 1434, folhetins, publicidade e ainda alguma poesia como a que Martins de Carvalho dedica a Amélia Janny, por altura do seu aniversário. De salientar, ao nível dos folhetins, «a Colecção de ditados e provérbios» coligidos pelo redactor deste periódico. 


\section{5 - HARPA DO MONDEGO}

Colecção de poesias contemporâneas redigidas

por uma sociedade de académicos

Coimbra, Imprensa da Universidade

1855

Colaboradores: C. S. Vasconcelos, F. Soares Franco Júnior, Ernesto Marecos, T. A. Ribeiro, A. Aires, J. S. da Silva Ferraz, N. X. de Brito, Alfredo de Carvalho, J. de Lemos, M. J. L. da Cunha e Silva, A. Vitorino da Mota, F. A. S. Vilaça, Silveira da Mota e J. M. Veloso

Formato: $16 \times 18 \mathrm{~cm}$

Periodicidade: Não indica

Preço: Não indica

Páginas: 126
Cotas:

BN: L. 3467 V.; L. 55748 V.

L. 90255 P.; L. 1068 A.

BGUC: RB - $25-27$

BPMP: -

BMC: GHC -3

\section{Objectivo}

«Harpa maviosa do Mondego ameno,

No silêncio da noite a horas mortas,

Por nascentes poetas afinada,

Faz vibrar teus sons harmoniosos;

Vai acordar os ecos d'essas margens,

Qu'outros vates cantaram n'outro tempo,

Tempo dourado, que resurge agora.

Irão soar cadentes n'esses bosques,

$180 \quad$ N'esses vales, no rio, nas colinas;

E hão-de os ecos saudosos repeti-los

Já longe e longe em mal distintas vozes.

Nem por frágil te assuste a negra sombra

D'esse trilho, que encetas inexperta;

Da crítica o soprar há-de açoitar-te;

Quando sensata presta-lhe respeito,

Quando baixa e mordaz só o desprezo. 
E vós, poetas, cuja fonte altiva

Ornaram louros já, vinde ajudar-nos;

Pegai de novo na esquecida lira,

P'ra que um canto recente possa ainda

Tornar os vossos nomes mais famosos»

(Harpa do Mondego,

Coimbra, Imprensa da Universidade, 1855, pp. 1-2)

\section{Conteúdo}

Harpa do Mondego é um periódico que trata, exclusivamente, de poesia.

A colecção completa deste periódico é de oito números, todos com o mesmo formato, mas sem indicação de datas. Todos os números têm dezasseis páginas, excepto o último que tem apenas doze. Termina com um índice final, formando-se um volume com 126 páginas. 


\section{$66 \cdot$ HOJE}

Revista Quinzenal de Literatura e Crítica

Coimbra, Tip. Minerva Central

20 Janeiro 1898

Redactores: Joaquim Gomes, Lopes de Oliveira e

Marques dos Santos

Colaboradores: Gonçalves Cerejeira, Mário Esteves,

Teófilo Braga, Júlio Dantas, Carlos de Lemos,

Carlos Malheiro Dias, Alfredo Serrano, Júlio

Lobato

Formato: $13,5 \times 19,5 \mathrm{~cm}$

Periodicidade: Quinzenal

Preço: Trimestre - 200 réis • Avulso - 40 réis

Páginas: $44^{(1)}$
Cotas:

BN: J. $982 / / 5$ P.

BGUC: -

BPMP: -

BMC: GHC -19/7

\section{Objectivo}

«Mais uma revista aparece à luz do claro e fecundo sol deste país onde a febre da publicidade cresce em proporção com o horror à letra redonda, horror que faz abortar, no ventre ubérrimo dos prelos, quantas vêm aparecendo. Este o destino que breve, talvez, nos aguarda, e cujo pressentimento nos tornaria, para isto, estacionários, e o intuito que à fundação destas coisas nos traz, não fosse, simplesmente o abalançarmo-nos para maiores derrotas no Mar da Arte, hoje mais cheio de limos do que pérolas, mas que é sempre Mar, isto é, a eterna síntese da Majestade e da Beleza.

E impelidos, pois, pelo entusiasmo da Arte ingénito em nós, e também, de alguma maneira, pelo egoísmo de aproveitar assim alguns momentos de ócio que o estudo nos deixa livres, que aqui aparecemos com a altivez que dá um nobilíssimo exemplo» (Hoje, n. ${ }^{\circ}$ 1, p. 1).

(1) Referem-se aos dois primeiro números. 


\section{Conteúdo}

Trata-se, essencialmente, de uma revista de carácter literário.

Segundo Carneiro da Silva, a colecção completa desta publicação é de três números, embora não refira a data do último número (Cfr. Ob. cit., pp. 72-73).

$\mathrm{Na}$ B.M.C., encontram-se apenas os dois primeiros, ambos com o mesmo formato.

Como revista literária, Hoje afirma-se, fundamentalmente, como um espaço de criação. Daí as inúmeras poesias e, também, textos em prosa como, por exemplo, o romance da autoria de Carlos Malheiro Dias com o título «A Fábrica», onde o seu autor nos dá conta das transformações que se vão operando com o processo de industrialização do país.

De salientar, também, o artigo «Positivismo e Evolucionismo», onde, a propósito de um livro de Caldas Cordeiro, Teófilo Braga reafirma as bases da filosofia positivista e a concepção dinâmica de evolução em Spencer.

Em «Crónica Literária», Lopes de Oliveira dá-nos não só conta das publicações que vão saindo dos prelos, como também lhes faz uma pequena apreciação crítica. $\mathrm{O}$ mesmo em relação aos periódicos, na rubrica «Em revista às revistas». 


\section{7 - INSOLENCIA}

Crítica irreverente da política e das letras

Coimbra,Tipografia Operária

Junho 1894 - Fevereiro $1895^{(1)}$
Cotas:

BN: -

BGUC: -

BPMP: -

BMC: GHC -19/VII

Director: Fernão Vaz ${ }^{(2)}$

Formato: $9,7 \times 16,6 \mathrm{~cm}^{(3)}$

Periodicidade: Mensal

Preço: 50 réis

Páginas: $28+\mathrm{IV}{ }^{(3)}$

\section{Objectivo $^{(4)}$}

\section{Conteúdo}

Trata-se de uma pequena revista, cujo objectivo essencial é criticar, não só o que se vai passando no mundo da política e da governação, mas também no campo das letras.

A colecção completa deste periódico é constituída por duas séries, com quatro números cada. Nem todos os números têm o mesmo formato e número de páginas. Segundo nos informa Carneiro da Silva, o n. ${ }^{\circ} 1$, da $1 .^{a}$ série, destaca-se, uma vez que o seu formato é de 60 x 26 milímetros (Ob. cit., p. 76).

Infelizmente, não conseguimos encontrar os números relativos à $1^{\text {ax }}$ série e, quanto à 2. ${ }^{\text {, }}$, encontra-se incompleta. Sabemos, no entanto, dos assuntos trata-

184 dos na 1. ${ }^{\mathrm{a}}$ Série, uma vez que, na 2.a , se encontram IV páginas contendo os sumários correspondentes aos números daquela série.

(1) Referem-se à $1 .^{\mathrm{a}}$ e $2 .^{\mathrm{a}}$ Séries.

(2) É o pseudónimo de Joaquim Nunes Borges Madureira de Carvalho, aluno da Faculdade de Direito.

(3) Referem-se apenas à $2 .^{\text {a }}$ Série.

(4) Não é referido, em virtude de não nos ter sido possível localizar a 1 a $^{a}$ Série, que é onde o autor faz a apresentação do periódico. 


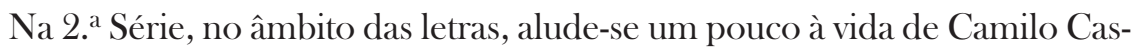
telo Branco, mas, fundamentalmente, para criticar o modo como certa imprensa noticiou o leilão que iria ser feito aos seus livros e outros objectos e também a forma como o mesmo decorreu, ou seja, «onde quatro vacões e dois ferrosvelhos, manhosos ruflões da vileta vizinha, disputaram por um pataco os livros e mais pretensos do escritório» (Insolências, 2. ${ }^{a}$ Série, $n^{\circ}$ 1, Outubro/Novembro de 1894, p. 16), ao contrário do que aconteceu em França, no leilão de Balzac.

Uma pequena e rápida apreciação, também, das obras: Belkiss de Eugénio de Castro e Filosofia do João Brás da Silva Pinto.

Invocando um certo sentido histórico, recordando a grandeza do país dos tempos de Aljubarrota, Ceuta, Índia e Ormuz, fazem-se profundas críticas à monarquia e seus sequazes. Ao Rei D. Carlos chamam-lhe «o primeiro e mais caro analfabeto do país» (Idem, p. 22); aos políticos critica-se a sua bajulação e sentido de oportunismo, porque, no princípio do ano, vão apresentar cumprimentos de Boas-Festas e Bom Ano ao Rei e, depois, «é ver recrutar ministros da monarquia nas redacções republicanas e chefes republicanos nas quadrilhas da monarquia» (n. ${ }^{\circ} 3$, p. 29). Daí que, em matéria política, o autor da publicação afirme, não só uma certa distância, mas também alguma independência, quando escreve: «É-me indiferente: tanto se me dá ir para a cadeia à ordem de Sua Magestade Carlos, como de sua excelência Teófilo» (n. ${ }^{\circ}$ 1, pp. 5-6).

Uma forte sátira para o modo como o nosso património é preservado. Cita-se o exemplo de um presépio da autoria de Machado de Castro, na Igreja da Estrela. 


\section{$68 \bullet$ OS INSUBMISSOS}

Coimbra, Tipografia União

1 Fevereiro 1889 - Março 1889

\section{Objectivo}

Não indica Pessoa, José Figueiredo Sobrinho

Formato: $13 \times 17 \mathrm{~cm}$

Periodicidade: Semanal

Páginas: 96
Cotas:

BN: J. 1588B.

BGUC: -

BPMP: P - A - 1546

BMC: GHC -2 - S

Colaboradores: Eugénio de Castro, Francisco Bastos, João de Menezes, Silvestre Falcão, Barbosa de Andrade, Mário Pinheiro Chagas, Simão da Costa

Preço: Série-12 n. ${ }^{\text {os }}$ - 600 réis • Avulso - 60 réis

\section{Conteúdo}

Os Insubmissos é uma revista de carácter literário, que pretende, fundamentalmente, denunciar e ridicularizar a sua congénere Boémia Nova.

Composta por seis números, têm todos o mesmo formato e número de páginas, dezasseis, apesar de os $\mathrm{n}^{\text {os }} .5$ e 6 terem sido publicados em conjunto.

A disputa entre Os Insubmissos e Boémia Nova diz respeito à discussão da primazia, na introdução de novas experiências rítmicas, estilísticas e influências, na literatura portuguesa. Esta questão é visível em artigos como «Tosquiando» e «Responsabilidades», mas sobretudo na secção «De lança em riste», que percorre toda a revista, onde Francisco Bastos escreveu: «No seu artigo de apresentação a Boémia Nova declara que procurará ser um jornal de ideias modernas, de orientação moderna, de moderníssima escola. Apesar desta declaração, porém, nem ideias modernas, nem orientação moderna, nem moderníssima escola encontramos nos escritos... Reflexos de Gonçalves Crespo, Eça de Queiróz, 
Cesário Verde, Guerra Junqueiro e Ramalho Ortigão, eis o que se nos depara - simples e únicamente» (n. ${ }^{\circ}$ 1, pp. 11-12), para além da apreciação de artigos, poesias, crónicas e contos de Boémia Nova.

No domínio do literário é interessante, também, o artigo «Poesia Científica», onde se relata a conversa havida, no Café Lusitano, entre Francisco Bastos e o Dr. Augusto Rocha, professor da Faculdade de Medicina e fervoroso adepto das ideias positivistas, sobre poesia. Augusto Rocha defende uma poesia que classifica de científica, isto é, «fazê-la entrar definitivamente no último período da evolução da mentalidade humana» (n. ${ }^{\circ}$ 2, p. 22) e de que é exemplo o poema intitulado «O Intestino Grosso», que aí se publica.

Referências também à Universidade, ao sexto centenário da sua fundação e ao foro académico, cuja abolição se pede. No artigo «Antes do Centenário», Barbosa de Andrade, tomando como exemplo os significados do tricentenário da morte de Camões e do centenário da morte de Pombal, em tom de fina crítica e bom humor, escreve relativamente ao da Universidade: «celebra-se porque tem seis séculos - é a apoteose da senilidade» (n ${ }^{\circ s} .5$ e 6 , p. 69).

Publicam-se também cartas de Mário Chagas, Simão da Costa Pessoa e de José Figueiredo Sobrinho, a propósito de um incidente entre Francisco Bastos e António de Melo, na Rua Larga. 


\section{$69 ・$ INSULTOS}

Crítica de coisas portuguesas

Coimbra, Tipografia Operária

Novembro 1894 - Dezembro 1894
Cotas:

BN: -

BGUC: -

BPMP: -

BMC: GHC -19/VII

Redactores: Guedes Teixeira, Alexandre Braga, filho

Formato: 12 x 17,8 cm

Periodicidade: Quinzenal

Preço: Três meses - 600 réis • Avulso - 100 réis

Páginas: 72

\section{Objectivo}

«A palavra aí fica, e, rasgando em torno um círculo de isolamento, dá-nos o orgulho de nos sentirmos sós.

De tão longe vem o nosso espírito que para chegar à vida uma fadiga o prostrou: - mergulhadores num mar desconhecido, os nossos olhos, acostumados à água deformadora das quimeras, não podem ver sem ódio a face traiçoeira dos homens.

Nesta hora amarga de civilização que passa numa visão de sangue enubla a vista de todos os que têm no coração um grito sufocado de revolta.

E para os que sofrem, em todas as noites de iniquidade, um infindável tormento de misérias e dores, para os crucificados na luta inglória do viver, para os que têm uma blasfémia na boca sem pão e uma ameaça nos pulsos algemados, que estas páginas vão abrir-se acolhedoras e amigas, ungidas de perdão e de piedade; mas para aqueles que vão fitando, olhar dilatado em ânsia, um predomínio a atingir, para aqueles que caminham, agressivos, egoístas, triunfantes, por sobre os humildes e por sobre os justos, para aqueles que sobem, sem uma hesitação e sem um remorso, a estrada fácil que conduz a todo o crime legal, sempre estas páginas hão-de ser insultuosas, porque sempre a Justiça há-de ser ultrajante.

Desdobrar-lhes a alma é, em cada consciência, abrir-lhes um presídio, e perdoado nos seja o crime - dizer-lhes a verdade é quase maculá-la» (Insultos, Novembro de 1894, pp. 3-4). 


\section{Conteúdo}

Trata-se de uma pequena publicação que procura criticar e denunciar situações que se verificam, não só ao nível da comunidade estudantil, mas também da sociedade portuguesa, em geral. Politicamente, a simpatia dos seus responsáveis vai para os ideais do republicanismo, apesar de tecerem algumas críticas à organização e direcção do partido.

Compõe-se esta publicação de apenas dois números, com o mesmo formato e paginação, tendo o primeiro sido publicado em Novembro de 1894 e o segundo no mês seguinte. De referir a existência de um suplemento com oito páginas e que ostenta, na parte inferior da última página, a data de Dezembro de 1894. Aqui se fala, exclusivamente, de Academia. Aliás, o título do texto é mesmo «Ainda a Academia».

Para além de pequenos textos a denunciarem a opressão a fracos e oprimidos, dois temas dominam nesta publicação: o primeiro, diz respeito à Academia e suas vivências; o segundo, tem a ver com a política portuguesa.

Relativamente à Academia, defende-se a ideia que não se impõem horizontes aos espíritos nem se definem rigores para a alma. Daí as críticas a certas fórmulas e práticas que nela existem e que contribuem para uma vida de submissão: a praxe, nomeadamente, a que se desenvolve à Porta Férrea (Canelão) «que manda receber a coices os que chegam « (p. 8); os insultos à cátedra e aos lentes por «cábulas e difamadores» (p. 9); certas formas de vida cultural como «coteries literárias, infantis e sem originalidade, degladiando-se em estéreis e insípidas discussões de café» (p. 10); às «troupes de opereta aos caloiros e aos gatos» (p. 10); e as récitas que mais não são que uma farsa «com que se deixa um passado de vergonha» (p. 11).

Lamenta-se a decadência em que vive a Academia e a incapacidade por esta demonstrada na reorganização do Clube Académico.

Quanto à política portuguesa ela é objecto de alguma análise no texto intitulado «O comício em Lisboa». Um certo desdém para com os partidos monárquicos, porque, para uma vida de regeneração, nada há já a esperar nem dos seus princípios nem dos seus homens. Palavras duras para com alguns, que apelidam de «imbecis» e «ladrões»; pouca simpatia para com a Carta Constitucional que apenas serve para "proteger bandoleiros e amordaçar homens» 
(p. 44); uma certa esperança na ideia republicana, mas para a qual é necessária uma «séria e completa organização» (p. 49), caso contrário a «resistência será nula» (p. 49).

Completa-se esta publicação com uma referência à música e a Viana da Mota, ao teatro e a Lucinda Simões. 


\section{$70 \bullet$ O IRIS}

Semanário Literário de Instrução e Recreio

Coimbra, Imprensa da Universidade

20 Março 1852 - 3 Abril 1852
Cotas:

BN: J. 330//8 P.; J. 400//9 B.

BGUC: -

BPMP: P-B-2165[5]

BMC: GHC -20/1-S

Administrador: Francisco Adelino de Andrade

Pacheco

Colaboradores: Abílio Augusto da Fonseca Pinto,

A. T. Barbosa, A. A. C. Carneiro, F. Soares Franco,

F. A. N. Pousão

Formato: 20,5 x 26,5 cm

Periodicidade: Semanal

Preço: Trimestre - 480 réis • Avulso - 60 réis

Páginas: 16

\section{Objectivo}

«Em Coimbra, que justamente se apelida o grande foco da civilização nacional... onde a profissão de muitos é ler, e ler o gosto e entretenimento de todos: a publicação de um jornal de letras é mais que uma condição de progresso - é uma urgente necessidade moral.

Geralmente falando, os jornais são os grandes motores da civilização moderna; são, como diz Henri Celliaz, os mais poderosos agentes do soberano do mundo - o pensamento. Reflexos maravilhosos de inteligência universal alumiam e esclarecem igualmente o palácio do rico e a choupana do pobre; o gabinete do sábio e a oficina do artista; difudindo por toda a parte o espírito civilizador, que impele o homem para a humanidade, e a humanidade inteira para Deus...

Os jornais literários de Coimbra pela sua parte, têm conseguido sempre viçosas coroas, porfiando incansáveis em imitar, na índole e nos frutos, os excelentes modelos da capital. Igualmente criadores e evangelizadores, são, além disso, nesta cidade, um glorioso padrão levantado por uma ou muitas gerações académicas à sua própria memória, e servem por tanto de duplicado incentivo aos briosos esforços das gerações que se lhes seguem... 
A Academia de Coimbra não tem renunciado, nem renuncia, o lugar que lhe compete na vanguarda da civilização do país, nem os deveres que lhe impõe uma honrosa existência de muitos séculos...

Se há três anos, como dizemos, a Academia de Coimbra não tem um jornal seu, é porque em certo modo se tem visto directa ou indirectamente empecida por essa, desgraçadamente tão ampla e tão forte influência da política...

Conhecedores da Academia, porque vivemos no seio dela, entendemo-lo assim; e convencemo-nos intimamente de que a publicação de um jornal literário, seu próprio, dependia hoje apenas das dificuldades materiais inerentes às empresas desta ordem. Com estas ideias tomamos à nossa conta aquelas dificuldades, e tendo conseguido vencê-las, apresentamos em público o IRIS que será um semanário literário de instrução e recreio, exclusivamente académico. Como tal as suas colunas serão sempre francas a todos os jovens, que frequentarem a Universidade, e que desejarem fazer conhecer pela Imprensa os exercícios em prosa ou verso com que se divertirem dos trabalhos escolares...

A direcção do IRIS deseja que os manuscritos, que lhe forem entregues para a publicação, lho não sejam sem que primeiramente os tenham revisto em particular ilustrações competentes da confiança dos autores; porém quando se ofereça nisto algum obstáculo, a Direcção procurará ter sempre entre os seus membros uma comissão conspícua, que terá a seu cargo aquela revisão, afim de se evitarem os erros ou irregularidades notáveis.

Se nos perguntarem o porquê adoptamos para esta publicação o título que a distingue, diremos que não fizemos deste ponto objecto de consideração especial, cedendo a ideia de propriedade, que primeiro se nos ofereceu, em apresentarmos o símbolo de bonança ao espírito de nossos escritores e leitores, depois de mais árdua tarefa. Com efeito, o tempo que o IRIS roubar aos seus escritores e leitores deve ser, na generalidade, o pouco que deixam ao descanso e distracção os trabalhos académicos ordinários» (O IRIS, n. ${ }^{\circ}$ I, Coim-

192 bra, 20 de Março de 1852, pp.1-2).

\section{Conteúdo}

Com uma vida bastante efémera, este pequeno periódico afirma-se como um jornal literário e recreativo e um defensor da instrução e da cultura.

A estrutura interna é sensivelmente a mesma nos dois números que compõem esta colecção. O mesmo acontece com o formato e paginação. 
A par de um espaço de criação literária, onde se salientam textos em prosa, mas sobretudo muita criação poética, poderemos dizer que a temática que mais domina é a temática da instrução e da cultura. É Abílio Augusto da Fonseca Pinto quem, no artigo intitulado «Instrução Primária» reflecte sobre aquela. Reconhecendo que a instrução «é uma necessidade geral de que depende a verdadeira felicidade de uma nação» (n. ${ }^{\circ}$, p. 9, col. 1), chama a atenção, não só para o trabalho que Pombal desenvolveu, mas sobretudo para o estado deficiente em que a instrução primária se encontra. Apontando algumas das causas dos nosso males, apela-se para os deputados, para o Conselho Superior de Instrução Pública e até para a imprensa, que têm, nesta matéria, um papel importante.

Ao nível da instrução secundária e superior publica-se uma tabela referente ao número de alunos que frequentam o Liceu de Coimbra e a Universidade, no ano lectivo de 1851-1852, pois, no entender da direcção de $O$ Iris, sendo este jornal um jornal académico é importante e essencial dar a conhecer o número de alunos.

Espaço de divulgação cultural nas referências e publicidade que faz às publicações Novo Trovador e Instituto. Jornal Científico e Literário. De salientar o artigo "Medicina. Anomalia da veia umbilical e sua importância na paracentese», onde, a par de matéria científica, se dá a informação, curiosa, que foi Teotónio Furnelle, de 22 anos, natural de Casais do Campo, freguesia de S. Martinho do Bispo, falecido em 31 de Janeiro de 1852, a primeira pessoa a ser sepultada no Cemitério da Conchada (Cfr. n. ${ }^{\circ}$ 1, p. 4, col. 2).

Completa-se este periódico com um pequeno espaço destinado a charadas e enigmas. 


\section{$71 \cdot$ JORNAL DOS ESTUDANTES}

Orgão da Academia Portuguesa

Coimbra, Imprensa Académica

10 Fevereiro 1896 - 10 Maio 1896
Cotas:

BN: J. 984//47 P.; J. 1436 B.

BGUC: J. $1647 / / 4 \mathrm{~V}$

BPMP: -

BMC: GHC $-20 / 8$

Editor: António da Silva Loureiro

Redactores: Carlos Lemos, Alberto Pinheiro, António Casimiro, Abel Andrade, Artur Leitão e Henrique de Vasconcelos, T. Rebelo, Augusto Soares e Teixeira de Vasconcelos

Colaboradores: Guedes Teixeira, Luís de Morais Carvalho, Evaristo de Carvalho, António Macieira, A. Feliciano Rodrigues, Afonso Lopes Vieira, Alexandre Braga, filho, Alexandre de Albuquerque, António Silveira, Augusto Gil, Gonçalves Cerejeira, Verediano Gonçalves, Alexandre de Matos e Vilela Passos

Formato: 23 x $33,8 \mathrm{~cm}$

Periodicidade: Semanal

Preço: Ano lectivo de 96 - 400 réis • Avulso - 20 réis

Páginas: 56

\section{Objectivo}

«Fundando este jornal, pretendemos suprir uma enorme lacuna aberta na vida académica portuguesa.

Sem centros locais de reunião e sem uma maior ou menor periodicidade na convocação de congressos gerais, que fossem, a um tempo, liame estreito da imprescindível fraternidade, que nos deve unir e concesso oportuno e próprio para nele se dirrimirem todos os assuntos vitais da classe; - a Academia Portuguesa, por culpa sua e por uma péssima orientação dos nossos governos tem levado, sobretudo nos últimos tempos, uma vida parca de revelação intelectual e, o que é pior, nada ou quase nada tem contribuído para essa larga e frutuosa reforma moral, que a Pátria nos vem pedindo, infelizmente debalde.

Deixámo-nos cair num profundo estado letárgico, antipático e condenável, sem vozes para protestos e sem laços para o trabalho...

À Academia portuguesa cumpre, agora mais que nunca, o imperioso e sacratíssimo dever de, novamente, vir ocupar o seu posto, pronta sempre a en- 
tranhadamente dedicar-se, pela imprensa, já que o não pode fazer pela acção em prol dessa árdua mas salubérrima transformação dos caracteres nacionais, - base sólida e única para o ressurgimento da pátria...

É, por isso, que as colunas deste jornal ficam, de par em par, abertas à colaboração de todos os estudantes, sejam quais forem os seus ideais e os credos políticos em que comunguem.

Nem outra podia ser a nossa orientação. Imprimir a este jornal uma feição acentuadamente conservadora ou eminentemente revolucionária seria, certamente, desaproveitar muitas forças, que, livres de máculas e de preconceitos, empenho terão também em pôr todo o seu valimento e todas as suas energias ao serviço da nossa causa...

$\mathrm{E}$, assim, vimos à arena da imprensa envergando apenas as nossas batinas e cobrindo as nossas capas, sem outros intentos que não sejam os de criar caracteres, sadios e bons, plenos de sentimentos nobres e capazes de heróicas abnegações; conservar, bem alto, a dignidade académica, e defender, acima de tudo e calorosamente, sempre que as circunstâncias o exigam, os nossos direitos e os nossos interesses» (n. ${ }^{\circ}$ 1, Coimbra, 10 de Fevereiro de 1896, p. 1).

\section{Conteúdo}

Jornal dos Estudantes é um periódico que, apesar de publicado em Coimbra, não diz respeito apenas à Academia de Coimbra. Nele se procuram congregar todos os estudantes de Portugal. Para além de outras referências como, por exemplo, a disponibilidade demonstrada pela Academia de Santarém, em cooperar com este jornal, para «de alto erguer a Academia do país» (n. ${ }^{\circ} 5$, Coimbra, 16 de Março de 1896, p. 39, col. 2), estão o sentido e a dimensão do subtítulo.

Reconhecendo que, no seio da Academia, havia desavenças e, sob o ponto de vista cultural e moral, uma certa decadência, esta publicação visa, não só contribuir para a construção de uma maior unidade estudantil, mas também para o seu enriquecimento e elevação cultural impulsionando sentimentos nacionais.

Compõe-se esta colecção de sete números, todos com o mesmo formato e número de páginas. De salientar, apenas, que do n. ${ }^{\circ} 1$ desta publicação faz parte um suplemento, de uma página, que contém um manifesto do grupo 
académico «Irmãos Unidos». Defensores da tradição e da fraternidade estudantil, este grupo constituiu-se como uma resposta às atitudes dos grupos políticos académicos. Reconhecendo que «na causa comum não se querem operários exclusivos», a sua proposta vai no sentido da «unidade do princípio monárquicorepublicano-anárquico-conservador» (Suplemento ao número 1 do Jornal dos Estudantes, s.p., col. 1). Para a história do grupo académico «Irmãos Unidos» podem colher-se alguns elementos nos artigos: «Discurso d'abertura do Club dos Irmãos Unidos pronunciado pelo presidente da sessão inaugural»e «Irmãos Unidos», assinado por Alexandre de Matos (Cfr. Jornal dos Estudantes, n. ${ }^{\circ}$ 4, p.p. 28, 31-32).

Num conjunto de artigos e pequenos textos, que se repartem, alguns deles, por vários números, duas temáticas dominam nesta publicação: a primeira, de natureza literária, engloba, não só produções, em prosa e verso, mas também estudos de literatura e recensões críticas a obras literárias; a segunda, diz respeito à comunidade estudantil e foca questões várias e diversas.

Relativamente à primeira e ao nível da produção literária contam-se textos com títulos como: «Excerpto», de Alexandre Braga, filho, «Carnalidade», de Alexandre de Albuquerque, «Agonia de uma alma», de Verediano Gonçalves e poesias várias de Guedes Teixeira, Vilela Passos e Santos Tavares, para se citarem apenas alguns; no domínio da literatura são importantes os artigos de Alberto Pinheiro sobre «O Sr. Teófilo Braga e a epopeia da Humanidade», «Um pouco de literatura», onde Henrique de Vasconcelos tece algumas considerações à obra de Guerra Junqueiro, nomeadamente, à filosofia de Os Simples, "As "Amethistas"», onde, numa breve síntese, nos dão conta das características que dominam a nova escola poética e, depois, nos falam da poesia de Elísio de Lima, que é um dos «novos», «No Pellourinho» e «A poesia doméstica na Itália», ambos da autoria de Carlos de Lemos, para tecer alguns comentários à obra de Vilela Passos e, depois de umas breves considerações, se referir a Giosué Carducci.

Ao nível da comunidade estudantil e num desdobramento mais estreito identificam-se questões como:

- Campanha em prol da reorganização dos Clubes Académicos, que «os governos, num sinistro receio conservador, não trepidaram um momento em desmoronar e dissolver» (n. ${ }^{\circ}$ 5, p. 33, cols. 1 e 2 ), sendo esta uma das razões apontadas para «um certo abaixamento na intelectualidade da academia de hoje» (Idem, p. 33, col. 2). Daí a chamada que a redacção do jornal faz à Academia 
de Coimbra, em dois artigos, de primeira página, intitulados mesmo «Club Académico".

- Interligada com esta questão, o convite à união e à fraternidade que devem ligar «os membros de cada academia e, a seu devido turno, todas as academias do país» (n. ${ }^{\circ}$ 7, p. 49, col. 2). Os Clubes Académicos seriam a pedra angular para se atingir este desiderato. Também o uso obrigatório da capa e batina, que defendem, para todas as academias, poderia ser «não o primeiro, mas um dos primeiros elos da fraternidade académica» (n. ${ }^{\circ}$ 2, p. 11, col. 2).

Este sentido de fraternidade e solidariedade académica deseja-se extensivo, também, às academias estrangeiras, nomeadamente de Espanha e de Itália, sempre que em causa possam estar políticas injustas e despóticas como as que os governos espanhol e italiano sustentam em Cuba e na Abissínia, como nos refere António Silveira num pequeno artigo intitulado «As Academias Latinas».

- Sociedade Filantrópica: fala-se dos objectivos que presidiram à sua criação; o que tem sido realizado; a remodelação que, possivelmente, vai haver nos seus Estatutos.

- A figura do Hilário e o que ela representa.

- A Academia do Porto e a homenagem a Almeida Garrett.

- Questões académicas outras são, também, as que se prendem directamente com os estudos: a obrigatoriedade de alunos terem que vir a realizar exames de alemão, para acesso a determinados cursos, quando antes se exigia o inglês, que alunos já fizeram, porque os governos, sem quê nem porquê, têm a «desgraçada mania... de tudo reformar» (n. ${ }^{\circ} 7$, p. 50, col. 1); contestação, também, para a nova lei de recrutamento militar que vem prejudicar gravemente os estudantes, na medida em que revogando os adiamentos, obriga os estudantes a alistarem-se nas fileiras ou, então, a pagarem uma determinada quantia, por cada adiamento.

Este sentido de contestação alarga-se, por vezes, a outras esferas. Contestase a posição assumida pelo governo em não promover à categoria de professor catedrático o Doutor Guilherme Moreira, só pelo facto de este mestre ser adepto das ideias republicanas, ao mesmo tempo que se critica a Faculdade de Direito, porque sendo assim enxovalhada, não foi capaz de «um arranco de revolta energético e decidido, para fazer prevalecer os seus direitos» (n. ${ }^{\circ} 6$, p. 47, col. 2).

Críticas também ao Parlamento que identificam como sendo o «tablado grotesco das patifarias nacionais» (n. ${ }^{\circ} 2$, p. 9, col. 2) e aos deputados que defendem a pena de morte. 
De salientar ainda neste periódico dois artigos: o primeiro, da autoria de Artur Leitão e intitulado «Por Cuba», onde não só se lamenta que, em Espanha, nem «uma só voz se erga bradando justiça para os cubanos e castigo para os assassinos» (n. ${ }^{\circ}$ 4, p. 27, col. 1), mas também se louva a resistência e o desejo de liberdade daquele povo; o outro é assinado por Abel Andrade e intitula-se «Política Europeia». Aqui se fala da desilusão do paraíso positivista e da reabilitação do religioso, se dá uma panorâmica geral do que vai pela Europa, para, por fim, se referirem os papéis importantes da Rússia e do Vaticano, aqui na pessoa de Leão XIII e suas encíclicas.

Completa-se este periódico com uma secção permanente, «Crónica a lápis/ Crónica», da responsabilidade de António Casimiro, onde não só se referem cenas e episódios de um quotidiano escolar coimbrão, mas também de acontecimentos outros como, por exemplo, a morte de João de Deus.

Nos dois últimos números, na secção de «Bibliografia», registam-se as publicações recebidas. 


\section{2・JORNAL LITERÁRIO}

Folha Quinzenal. Destinado a artigos

de literatura e ciência

Coimbra, Imprensa Literária

Janeiro 1869 - Setembro 1871
Cotas:

BN: J. 129 B; J. 389 M.

BGUC: $10-7-7$; 9-(3)-20-20

BPMP: -

BMC: GHC $-19 / 7$

Responsávél: A. M. Seabra de Albuquerque

Redactores: J. J. Lopes Praça, F. Adolfo Coelho, António José Teixeira, G. de Vasconcelos de Abreu, Francisco Inácio de Mira, G. A. Gagliardini, J. da Silva Macedo, A. Vieira

Formato: 17 x 23,3 cm

Periodicidade: Quinzenal

Preço: Semestre - 400 réis

Páginas: $1 .^{\circ}$ Vol. $-216 \bullet 2 .{ }^{\circ}$ Vol. -92

\section{Objectivo}

Não indica

\section{Conteúdo}

Jornal Literário é uma publicação que procura, fundamentalmente, ilustrar e instruir. Trata-se de um periódico que podemos classificar de cultural, na medida em que se caracteriza pela inclusão e tratamento de um leque de temas bastante grande e diversificado.

Compõe-se esta colecção de trinta e seis números, compulsados em dois volumes, com 216 e 92 páginas, respectivamente. Terminou em Setembro de 1871, por «circunstâncias particulares» (n. ${ }^{\circ}$ 36, p. 92, col. 2), segundo as palavras dos seus responsáveis.

Compõe-se esta publicação de um conjunto de textos e artigos que abarcam várias áreas do saber, onde se tratam questões como: 
-Educação e Ensino: publicação e apreciação de documentos vários relativos ao Colégio das Artes; o ensino superior na Alemanha e outros países; influências de autores estrangeiros (Tiberghien, d'Ahrens, Amadée Jacques, Jules Simon e Émile Saciset) nos nossos livros escolares.

- História: História Local (memória dos acontecimentos passados em Almeida, distrito da Guarda, aquando da ocupação daquela praça por D. Miguel, no tempo das lutas entre liberais e absolutistas. Esta memória «tem alguma importância não somente por interessar à nossa história política contemporânea, mas porque foi escrita por um liberal ilustrado e que foi testemunha e actor dos sucessos narrados» (n. ${ }^{\circ} 6$, Abril de 1869, pp. 50-51). Diga-se, também, que o autor desta memória «esteve preso desde 29 de Outubro de 1831 até 18 de Abril de 1834. Na parte final desta memória existe uma relação com o nome dos presos que faleceram na dita praça de Almeida, por causa dos maus tratos que lhe foram infligidos; ainda no âmbito da história local destaque para um estudo e notícias sobre Montemor-o-Novo e notícias históricas e arqueológicas da cidade de Beja - o Convento de Santa Clara); personagens ilustres do século XVI - o Dr. João Afonso de Beja; contributos para a história da Igreja em Portugal.

- Direito e Sociedade: direito civil - a questão das segundas núpcias; direito constitucional (bibliografia do direito constitucional português; a Carta Constitucional de 1826 e os direitos do cidadão); direito administrativo (questões de desamortização ${ }^{(*)}$; a filosofia do direito - Dr. Joaquim Maria Rodrigues de Brito.

- Língua e Literatura Portuguesas: apontamentos vários para a história da nossa língua; questões de etimologia e lexicologia da língua portuguesa; os cancioneiros portugueses; apreciação das obras O Grande Dicionário Português ou Tesouro da Língua Portuguesa de Fr. Domingos Vieira e Teoria da Conjugação em Latim e Português de F. Adolfo Coelho; glossário de palavras 200 portuguesas derivadas do árabe.

- Numismática: numismática portuguesa; o monetário da Biblioteca da Universidade.

- Agricultura e Pecuária: breves notícias acerca destas matérias no distrito de Coimbra.

(*) Trata-se de um trabalho que foi apresentado em 12 de Maio de 1866, na aula de Direito Administrativo, em Coimbra. 
Da autoria de A. Vieira o estudo intitulado «Fisiologia. Velocidade do sangue e velocidade geral da circulação».

De salientar ainda alguns documentos e notas sobre a questão que se travou entre José Anastácio da Cunha e José Monteiro da Rocha.

Completa-se esta publicação com a secção de «Expediente». 
73 - LANTERNA MÁGICA ${ }^{(1)}$

Fevereiro de 1818 Cotas:

BN: -

BGUC: -

BPMP: -

BMC: -

(1) Tratar-se-ia de um periódico manuscrito que teria usado, também, o título de Trombeta e visava criticar a acção desenvolvida por D. Francisco de Lemos à frente da Universidade reformada.

Segundo nos informa Carneiro da Silva (Ob. cit., p. 82), não há notícia da existência de qualquer número. Aliás, Joaquim Martins de Carvalho, na relação que nos dá dos jornais que se publicaram em Coimbra, entre 11 de Julho de 1808 e 11 de Julho de 1908, também não o refere. (Cfr. O Conimbricense, Ano 61. ${ }^{\circ}$, n. ${ }^{\circ}$ 6231, de 11 de Julho de 1908). 


\section{4・A LIBERDADE}

Periódico político, literário e comercial

Coimbra, Tip. de J. T. Andrade Pacheco

24 Março 1858 - 5 Junho 1858
Cotas:

BN: J. 1702//14 V.

BGUC: -

BPMP: $\mathrm{P} / \mathrm{C} / 1073$

BMC: GHC $-21 / 6$

Editor: José Gomes de Sousa,

Redactores: José Dias Oliveira da Cunha Viamonte, Eusébio Cândido Furtado Coelho

Colaboradores: A. R. Sampaio, F. de Sá Vasconcelos Albergaria

Formato: 28,5 x $45,5 \mathrm{~cm}$

Periodicidade: Bimensal

Preço: Trimestre - $1 \$ 000$

Páginas: 4

\section{Objectivo}

"A liberdade é um direito sagrado de todo o cidadão, garantindo pelo nosso código político e pelas ideias do século. O homem tem gravado no coração o amor da liberdade, e um povo ilustrado rejeitará com desprezo um governo, que atente contra os seus direitos...

As instituições liberais são uma necessidade justificada pela história...

A liberdade é o mais poderoso motor da ilustração, e esta a maior garantia do progresso e das instituições liberais.

As ideias que deixamos apontadas são as que abraçamos e que nos propomos defender com profunda convicção; porque as julgamos as únicas possíveis e que mais conduzem à prosperidade do país a que nos honramos de pertencer e que está dando a muitas nações um grande exemplo de liberdade, ordem e tolerância.

Nascidos numa sociedade livre, acostumados desde tenra idade a ouvir e repetir estas ideias, e, além disto, a profunda convicção adquirida pelo estudo dos factos obriga-nos a militar neste campo em que podem falecer-nos as forças, mas nunca as boas intenções. É mais um soldado, que corre a alistar-se nas fileiras da liberdade, à qual prestará todo o seu apoio» (A Liberdade, n. ${ }^{\circ}$ 1, Coimbra, 24 de Março de 1858, p. 1). 
«Não somos exclusivos de alguma facção política. Queremos a liberdade e havemos de perseguir sempre os déspotas, onde se encontrarem.

Hão-de ver-nos muitas vezes louvar e apoiar o procedimento dum partido, e muitas outras reprová-lo, quando estiver em oposição com os interesses do povo, de quem somos sinceros amigos, e pelo qual faremos os maiores sacrifícios.

Não lisonjearemos nunca os partidos, porque somos inexcedivelmente independentes...

Não aprovaremos nunca a desordem, mas defenderemos sempre com a pena e com as armas os direitos, prerrogativas e foros populares, quando alguém quiser atentar contra eles.

Aborrecemos as revoluções e os seus provocadores, quando se não quer alcançar um fim justo e razoável, e quando servem somente para o engrandecimento dum homem ou de um partido; mas aprovamo-las sempre que se quer reivindicar um direito, adquirido à custa de grandes sacrifícios e de que os caprichos de um homem nos querem espoliar.

Eis a nossa profissão de fé, que é a dos verdadeiros progressistas e amigos do povo (Idem, n. ${ }^{\circ}$ 5, Coimbra, 7 de Abril de 1858, p. 1).

\section{Conteúdo}

Para além de literário e comercial, conforme nos indica o subtítulo, esta publicação estudantil afirma-se, essencialmente, como um jornal político.

Todavia, à semelhança de muitos outros, os seus redactores excluem qualquer filiação partidária, para se definirem como «inexcedivelmente independentes», procurando, desta forma, defender melhor e sempre os «interesses do povo, de quem somos sinceros amigos», uma vez que «enquanto os

204 partidos não puserem de parte a ambição e má fé, a marcha governativa há-de ser constantemente embaraçada» (A Liberdade, n. ${ }^{\circ}$ 6, p. 2, col. 1).

Com o nome de $A$ Liberdade, o seu discurso de protesto é evidente, sobretudo ao nível dos artigos de fundo, sempre que em causa estão direitos, liberdades e garantias, porque «a liberdade é um direito sagrado de todo o cidadão».

Ao longo dos vinte e dois números que compõem esta colecção, a sua estrutura interna é, sensivelmente, a mesma, apesar de o subtítulo do primeiro 
número não acompanhar o periódico na sua total existência. Normalmente, a primeira página é dominada pelo artigo de fundo, na maior parte das vezes sem qualquer título. Seguem-se, depois, outros textos e rubricas várias. Destacam-se como secções permanentes ou quase permanentes as seguintes: «Noticiário», onde se dão informações e notícias várias do país e do estrangeiro; «Efemérides Históricas», espaço onde se evocam acontecimentos ocorridos em determinados anos; «Exterior», com notícias telegráficas do mundo; «Comércio. Praça de Lisboa. Acções e fundos públicos», coluna informativa sobre o preço que corre, em Lisboa, dos metais, acções e fundos públicos, cereais e outros géneros. No que a estes diz respeito, para além de Lisboa, dão-se, por vezes, informações de outras praças, nomeadamente Porto e Coimbra.

Nos artigos de $A$ Liberdade perpassam, fundamentalmente, duas grandes temáticas: a primeira e mais importante é a que se prende com o acto eleitoral, em consequência da dissolução das cortes, onde «o governo procurou a salvação da sua existência política..., contando talvez com grande maioria na câmara futura» (n. ${ }^{\circ}$ 3, p. 1, col. 1); a segunda tem a ver com a política governativa em geral.

Num desdobramento mais estreito dão-se a conhecer: o manifesto eleitoral Regenerador; Comissão Central da Coligação que então se formou; publicação da lista dos deputados da coligação pelos círculos eleitorais de Coimbra, Figueira e Lousã; esclarecimentos e conselhos aos eleitores; a derrota da Coligação e as práticas ilícitas levadas a cabo pelo governo e seus seguidores; publicação dos resultados eleitorais de diversos círculos; pareceres de assembleias de apuramento; notas sobre as eleições em Coimbra e Chaves; o novo parlamento; carta de Alexandre Herculano aos eleitores de Sintra; imprensa partidária; problemas de segurança e criminalidade no país; o estado do nosso sistema prisional e a necessidade de reformas; imprensa e ilustração do país; necessidade de instrução, sobretudo primária; a falta de desenvolvimento do país (Ex.: o caso da Covilhã); o problema dos impostos e sua cobrança, porque há «um desleixo produzido ordinariamente por considerações pessoais» (n. ${ }^{\circ}$ 2, p. 1, col. 2); a má governação, sobretudo do ministro António José Ávila, a quem são tecidas duras e violentas críticas.

Completam este periódico, documentos como:

- a sessão de 20 de Março de 1858 da Câmara de Deputados; 
- discurso de D. Pedro V, por ocasião da distribuição dos prémios aos alunos da Escola de Mafra, por ele criada (colhem-se elementos para a história da escola);

- «Variedades». Julgamento dos réus que atentaram contra a vida do imperador dos franceses. Tribunal criminal do Sena. Audiência de 25 de Fevereiro; - Texto que a Universidade de Coimbra enviou a D. Pedro V por ocasião do seu casamento e a resposta do Rei;

- Publicam-se as contas de um bazar que decorreu no Jardim Botânico, em benefício da Sociedade Filantrópica-Académica;

- Alguma publicidade. 


\section{5 - A LIBERDADE}

Coimbra, [s.l.]

15 Março 1896 - 12 Abril 1896
Cotas:

BN: J. 979//14 P.

BGUC: -

BPMP: -

BMC: GHC -2

Administrador: João Marques dos Santos

Secretário: António Pratas

Editor: Joaquim Fonseca

Redactor: Francisco Carlos Soares

Formato(s): $17 \times 22,5 \mathrm{~cm}-1 .{ }^{\circ} \mathrm{n}^{\circ}$

$13,5 \times 20 \mathrm{~cm}-2 .{ }^{\circ}$ e $3 .^{\circ} \mathrm{n}^{\text {os }}$

Periodicidade: Semanal

Preço: Mês -50 réis

Páginas: 4 - 8

\section{Objectivo}

«Sai hoje à luz este pequeno trabalho a que nos dedicamos. Os extractos que contém... não são produtos intelectuais porque poucos ou nenhuns possuímos nós, mas sim meros desejos de..... os nossos leitores...» (n. ${ }^{\circ}$ I, p. 1) ${ }^{(1)}$.

\section{Conteúdo}

Trata-se de um pequeno e modesto periódico copiografado, que não foi além do terceiro número, sem interesse de maior, e cujos objectivos podem sintetizar-se em divertir e ilustrar os leitores, em denunciar e criticar situações, nomeadamente as referentes ao meio estudantil.

Tanto no formato como na estrutura interna, o primeiro número é relativamente diferente dos outros dois.

(1) Certamente por razões técnicas, esta página é de leitura difícil. Daí a razão pela qual não nos foi possível ir mais além. Aliás, esta imperfeição é reconhecida pelos próprios responsáveis, quando escreveram: «Pedimos desculpa aos nossos leitores da deficiência da primeira página devido à nossa inexperiência» (Idem, n. ${ }^{\circ}$ I, p. 4). 
A par de textos literários, em prosa e verso, (o n. ${ }^{\circ}$ III tem mesmo uma «Secção Poética»), o que de mais interessante há a assinalar, é uma pequena abordagem histórica, na evocação que fazem do episódio do Gungunhana, das campanhas de Mouzinho de Albuquerque, a quem chamam «o intrépido herói de África» (Idem, n. ${ }^{\circ}$ II, p. 2, col. 2) e ainda nas considerações que tecem sobre o problema de Cuba. Para divertimento, uma «Secção Recreativa», com textos de entretenimento.

De distinguir, também, a abordagem que se faz sobre a questão dos feriados, no seio da Academia, com o artigo "A Academia Política». Aqui se denunciam e criticam as atitudes de republicanos e monárquicos. Assim: «Pode-se já adivinhar a luta que surgirá entre estes dois Centros (republicano e monárquico). Mas para quê? Com que fim? Que necessidade há de isto? Se resultassem daqui algumas garantias à academia bem mas vejo pelo contrário desarmonia e desinteligência entre eles» (Idem, p. 1, col. 2). Em tons de humor e alguma ironia, conclui: «Não haverá quem funde um centro como este e o denomine «Feriadista» (Idem).

Completam este periódico um folhetim e críticas a outras publicações. 


\section{$76 \bullet$ O LICEU}

Semanário Científico e Literário

Coimbra, Imprensa Literária

9 Fevereiro 1867 - 4 Maio 1867
Cotas:

BN: J. 147//4 B.; J. 320//16 P.

BGUC: $10-9-7$

BPMP: -

BMC: GHC $-20 / 2$

Colaboradores: César de Sá, J. Palmela, Augusto

Manuel Alves da Veiga, Campos Carvalho, J. V.

Mascarenhas Pedroso e M. J. Alves de Morais

Formato: $19 \times 26,5 \mathrm{~cm}$

Periodicidade: Semanal

Preço: Trimestre - Coimbra - 600 réis

Províncias - 650 réis

Páginas: 8

\section{Objectivo}

Não indica

\section{Conteúdo}

Como o próprio título e subtítulo indicam, trata-se de um pequeno periódico de alunos do liceu que aborda, essencialmente, questões de natureza literária e científica, reflectindo assim um pouco das suas vivências académicas.

Com uma estrutura idêntica nos seis números que compõem esta colecção, saliente-se a ausência de um artigo de fundo a dominar a primeira página e a existência de uma secção permanente intitulada «Revista», da autoria de César de Sá, que é uma espécie de crónica, onde «tudo enfim pode ser descrito, tudo pode ser contado» (n. ${ }^{\circ} 1$, p. 8 , col. 1 ).

Como assuntos de maior relevo destacam-se, repartidos em artigos vários, por diferentes números, os seguintes ensaios: «A Filosofia de Alexandria»; «Ensaio sobre filosofia alemã. Kant e a sua escola»; «A pena de morte» e «O ideal da Arte». 
No domínio das letras, para além do conto «Abnegação» e de várias poesias, apresenta-se um soneto de Bocage e apontam-se algumas características deste poeta.

Termina este periódico com uma página de história sobre o reinado de $\mathrm{D}$. João III e um artigo sobre agricultura e classes agrícolas, onde, para além de uma visão histórica global daquela, se defende uma instrução agrícola elementar, adaptada às localidades, e uma propagação das máquinas. 


\section{$77 \cdot$ A LIRA}

Publicação Literária

Coimbra, Imprensa Académica

Janeiro 1874 - Abril 1874
Cotas:

BN: J. 1314 B.

BGUC: $10-1-15-35$

BPMP: -

BMC: -

Director: Raul de Castro

Colaboradores: Emídio Garcia, Amélia Janny, Acácio Antunes, César de Sá, Silva Ramos, J. M. Fragoso, João de Amorim, Cândido de Figueiredo, António Cardoso, Gaspar de Lemos, Guilherme Braga, Alberto Carlos e José de Ornelas

Formato(s): 14 x $20 \mathrm{~cm} \bullet 16,3 \times 22,5 \mathrm{~cm}^{(1)}$

Periodicidade: Bimensal

Preço: Trimestre -360 réis • Mês -120 réis

Páginas: $64^{(2)}$

\section{Objectivo}

«No firmamento da moderna literatura, marchetado de mil sois fulgentes, não é raro lubrigar-se o débil brilho de uma e outra estrela, que, apesar de viverem uma vida efémera, se tornam, contudo, criadoras para com a humanidade pela sua ainda que fraca influência, prestada à santa cruzada da civilização.

Símbolos das aspirações de espíritos, forcejam por içar-se a Páramos, donde irradia a luz do progresso, com o nobre intuito de ali colherem bálsamo que suavize as úlceras da ignorância letárgica, em que os homens jazem acorrentados. Mas tão sublimes ambições caiem muitas vezes fulminadas pelo raio da indiferença!...

Tributando ao esquecimento estas funestas eventualidades, aqueles, a quem no cérebro pululam as ideias do progresso, repelem o domínio do desalento sobre o seu coração e caminham e sobem instigados pelo acúleo da esperança. É que a esperança, perdulária de blandícias para com o homem até ao último suspiro da existência, anima-o a seguir avante na estrada que encetou, como outrora a nuvem de fogo servia de bússola a Moisés, internado no deserto.

(1) As medidas maiores referem-se a um segundo exemplar que não foi aparado.

(2) Estas páginas dizem respeito aos quatro primeiros números. 
A esperança também é o nosso farol. Sem desfitarmos os olhos dela, tentamos erigir este exíguo monumento, em cujo destino talvez se divise o lutuoso cunho duma morte precoce. Mas não importa. Resta-nos como galardão aos nossos esforços o termos mais uma vez justificado o dito de Eugene Pelletan le monde marche» (n. ${ }^{\circ}$, p.p. 3-4).

\section{Conteúdo}

Trata-se, conforme o subtítulo o indica, de um periódico de índole essencialmente literária.

Compõe-se esta colecção de cinco números, mantendo sensivelmente a mesma estrutura.

Em sentido figurado, Lira significa talento poético e arte de versejar. Não admira, por isso, que uma boa parte das páginas deste periódico sejam dedicadas à criação poética.

O texto em prosa tem aqui, também, o seu lugar, de que é exemplo «Aldara», de César de Sá e «Aitorvic», numa tradução de Fernandes Rocha.

Completa-se este periódico com um importante artigo da responsabilidade de Emídio Garcia sobre a "Importância dos estudos históricos nas ciências jurídico-sociais e o ensino da história de Portugal». Reconhecendo que as leis e o direito são um produto histórico e que a história é um auxiliar precioso de outros conhecimentos, Emídio Garcia, depois de recordar o contributo que Melo Freire, Herculano, Teófilo Braga e outros deram à nossa história e comparando a organização dos nossos estudos com a de países estrangeiros, não deixa de referir que os nossos «obedecem ainda aos programas clericais e às inspirações do claustro» (n. ${ }^{\circ}$ 2, p. 20). Reconhece, igualmente, que o estudo da história de Portugal se faz «apenas elementar e desordenadamente nos cursos do liceus» (n. ${ }^{\circ}$ 4, p. 51), de que resultam carências graves para o ensino superior. Criticando a pequenez dos nossos programas, defende a sua reformulação, advoga um estudo mais profundo da nossa história, em lugar da dos Assírios, Caldeus e outros e, em termos pedagógicos, aposta na liberdade do professor, que diz ser superior às «emaranhadas urdiduras científicas e literárias das secretarias de estado» (Idem, p. 52). 


\title{
78 - LITERATURA OCIDENTAL
}

\author{
Ciências, Letras e Artes/colaborado por \\ Cotas: \\ escritores portugueses e espanhóis \\ BN: J. 1325 B. \\ Coimbra, Imprensa Académica \\ BGUC: $10-9-15$ \\ BPMP: - \\ Março 1877 — Janeiro 1878 \\ BMC: GHC - 19/4
}

Redactor: Sérgio de Castro

Colaboradores: Alexandre da Conceição, Sílvia

Ramos, Coelho de Carvalho, Magalhães Lima, Guiomar Torresão, José Frederico Laranjo,

Macedo Papança, Júlio César Machado, Gonçalves

Crespo, Luciano Cordeiro, Vicente Pinheiro, Amélia Janny, Alberto Braga, António Vasco de

Melo, António Viana, Augusto da Fonseca, José

Castelo Branco, Teófilo Braga, Cândido de

Figueiredo, Bento Moreno, Eduardo Burnay,

A. A. Fonseca Pinto

Formato: $16 \mathrm{x} 23 \mathrm{~cm}$

Periodicidade: Não indica

Preço: Série de 6 n. ${ }^{o s}-1$ \$200 réis

Páginas: 96

\section{Objectivo}

«O jornalismo português, no último período, atingiu o máximo desenvolvimento, mas foi monopolizado para a política, para a luta de todos os dias, para o jogo das facções. Cada jornal tem a sua igreja, e reverencia o orago da própria freguesia...

E foi isto desde todo o sempre. Exceptuem o romance, e não encontram no antigo jornalismo português uma feição característica de nenhuma das épocas em que se manifestou.

O favor do público requesta-se com a vida alheia, com a má língua de quem só vê senões no próximo seu igual, mas se tratarem de lhe fotografar a sua feição, de lhe escrever a história, de lhe retratar os costumes, de lhe criticar pelo bom senso o desvairamento das ideias ou das obras práticas - foge, porque teme, e não auxilia; é renitente, é rotineiro...

Vamos contra a corrente, talvez com perigo de perdimento, mas com coragem e cometimento de uma boa acção... 
Hoje um jornal literário e de vulgarização científica não pode tomar por modelo o Panorama, ainda com a cor local da literatura clássica, nem o maneirismo doce da mocidade que em Coimbra sacrificava a Apolo sob o patrocínio de Minerva.

O Trovador retrata o bom tempo de um anacronismo pastoril, em que se viam paixões de alma espelhadas na corrente que beija a Lapa dos Poetas.

Mas nós, respeitando a boa inteligência dos colegas de ontem, queremos ir além: somos do nosso tempo, sem vestir a nudez que não é de hoje, mas que se perde na lenda genésica, de que o próprio Bergier não sabe o local.

No jornal vemos um sacerdócio, porque lhe consideramos uma missão; e, tão longe vamos, que lhe impomos obrigações. Estas não se amiúdam em programa de pompa, porque é provado que mentem sempre estas minudências.

No meio da literatura que aí se retrata, desordenadamente, teremos por guia o bom senso. Não fantasiamos ideais extravagantes, nem fazemos profissão de fé a supostas escolas. E dizendo isto, que é claro, que é inteligível, só pedimos que nos não chamem ecléticos.

Agora sobre o título: Literatura Ocidental não denota imodéstia... este jornal receberá colaboração de escritores de Espanha, para assim irmanarmos as duas literaturas... Deste modo o título é apenas um distintivo, que tem só o valor de imprimir na nossa escrita o carácter que lhe é próprio, sem limitarmos à nacionalidade qualquer problema científico que houvermos de tratar»(Literatura Ocidental, n. ${ }^{\circ} 1$, p.p. 5-6).

\section{Conteúdo}

Literatura Ocidental é uma pequena publicação, que não foi além do terceiro número, todos eles com o mesmo formato, número de páginas e estrutura interna, e onde os seus responsáveis e colaboradores, simpatizantes que são das ideias de Comte, Littré, Spencer e outros, procuram, não só instruir, divulgando conhecimentos, mas também formar mentalidades. É, fundamentalmente, neste sentido que devem ser lidos e entendidos os principais artigos que dominam nesta revista como, por exemplo: «Anarquia de exame», onde Alexandre da Conceição, reconhecendo existir uma certa indisciplina intelectual que é fruto de uma transformação das ideias, advoga que a filosofia positivista «não é um perigo, é uma evolução fatal e necessária do espírito humano na sua ascensão constante para o bem e para a verdade» (p. 9); «Política Positiva» e «Nova Fé», 
ambos da autoria de Vicente Pinheiro que reflecte, em termos políticos, educativos e religiosos, sobre a influência e a importância que as novas ideias e maneiras de pensar podem ter para os povos; ao nível da comunidade estudantil, Sérgio de Castro, no artigo «Poetas e prosadores académicos», alude à influência que a geração de Antero de Quental teve na Academia, deixando-lhe «o incitamento a um estudo novo, de generalização e de dedução de origens» (p. 63), para depois citar os nomes de Vicente Pinheiro, António Vasco de Melo, António Viana e José Castelo Branco como coriféus de uma nova escola.

De salientar, também, os artigos de Teófilo Braga e Luciano Cordeiro intitulados «Transição da biologia para a sociologia» e «Explorações oceânicas».

No domínio da literatura assinalamos os estudos «A evolução do romantismo» em Portugal, de Sérgio de Castro, «Literatura dissolvente» de Augusto da Fonseca, onde em traços rápidos, se referenciam as escolas romântica e realista, e «Fernan Caballero» (pseudónimo da escritora espanhola Cecília Bohl), da responsabilidade de José Simões Dias, que nos fala um pouco da vida e obra da escritora, para além dos romances «Folhas de Rosa» e "António Fogueira», de José Frederico Laranjo e Bento Moreno, respectivamente.

No campo da ciência económica, o artigo «Economistas Espanhóis», de J. Simões Dias cuja intenção é dar relevo aos trabalhos dos mais insignes economistas do país vizinho. Citando alguns, fala-nos, muito especialmente, de Feliciano Herreros de Tejada e sua escola.

Completa-se esta publicação com algumas poesias e apreciação crítica de obras e opúsculos dados à estampa 


\section{9 • A MÁ LÍNGUA}

Coimbra, Tip. de Luís Cardoso

10 Dezembro 1898 - 15 Janeiro 1899
Cotas:

BN: -

BGUC: -

BPMP: -

BMC: GHC $-19 / 2$

Director: José Lopes de Oliveira

Formato: 14,5 x 21,8 cm

Periodicidade: Quinzenal

Preço: 6 Números - 200 réis •Avulso - 40 réis

Páginas: $32^{(1)}$

\section{Objectivo}

«Num regime abandalhante de aberto e descarado elogio-mútuo, em que a consciência desaparece e o escritor se converte num lambe-mãos que enoja e indigna, A Má Língua é talvez uma revista deslocada e condenável como perturbadora da boa quietude dos espíritos pacíficos, com convicções arraigadas de que todos cá por casa são uns génios, a avaliar pela inundação de livros na última década...

Em todo o país, e cada vez acentuando-se mais, há um mot-d'ordre violento e infernal contra os proletários que trabalham, os humildes que lutam e todos os que estudam e pensam independentemente...

A política é uma farsa ignóbil em que todos se lançam e em que os descarados ganham sempre...

A educação da mulher está inteiramente por fazer, reduzindo-a assim quase a um estado deprimente de simples fêmea, sem uma ideia de vida e trabalho, alimentado o espírito com a leitura diária dos folhetins eróticos dos jornais.

O ensino profissional quase não existe, encerrado em processos rotineiros, sem um meio de acção inteligente e livre.

A escola primária, descurada e com um pessoal mal remunerado, só fornece o ensino de ler, escrever e contar, mesmo rudimentarmente deficientíssimo.

(1) O n. 2 está incompleto, pois começa com a p. XXV, quando o correcto seria com a p. XVII. 
Nas aulas superiores observa-se uma geral inferioridade que raras vezes atinge o medíocre. Quase nunca dali sai um homem apto para o trabalho honrado, distinto dos outros pela sua superioridade intelectiva.

As belas-artes reduzem-se a estudos comesinhos e mal feitos...

Neste século de lutas e paixões desordenadas que teve como aurora uma nova época de liberdade humana... constituíram-se os fundamentos duma sociedade nova...

Formam-se as ciências comparativas da linguagem e das religiões, estudam-se a origem do direito e as literaturas, acentua-se o grande valor científico da Física e Química na sua aplicação prática..., constitui-se a Etnologia e cria-se a Biologia que destrói os erros ridículos do período metafísico, e avigora-se a corrente filosófica disciplinada por Descartes no Século XVII, com a cooperação de Spencer, Huxley e Comte, que cria a grande concepção da Religião da Humanidade.

E ao mesmo tempo que se opera esta grande revolução científica, renova-se num novo campo mais humano e verdadeiro, deixando de ser dum grupo para pertencer ao mundo - a Arte - que consubstancia todas as grandes aspirações...

É perante esta assombrosa revolução científica e artística que os escritores em Portugal se conservam afastados e indiferentes.

E se este afastamento exprime somente a regra, que tem brilhantes excepções em grandes literatos portugueses, é preciso que façamos deles distinção...

Para este saneamento literário procuraremos contribuir, ainda que restritamente, mas sem atender a vaidades que procurerm impôr-se ou triunfar.

Irei também, quando puder, anotando a vida contemporânea, picaresca e ridícula, mas com pedaços de tragédia sangrenta a miseranda na vida do Povo» (A Má Língua, N. ${ }^{\circ}$ 1, p.p. I-III).

\section{Conteúdo}

Trata-se de uma pequena e modesta publicação, que não passou do segundo número, mas onde se assume uma posição bastante crítica em relação à grande maioria dos novos poetas e prosadores, acusando-os de um lirismo gasto e banal e de uma total ausência de ideias. Reflectindo sobre as características das suas produções, Lopes de Oliveira, no artigo «A Arte dos Novos», diz-nos que elas apresentam «a vacuidade duma imitação incolor e desenxabida» (p. XIV). 
Com esta e outras críticas e com a evocação que se faz de Zola e dos «velhos» como Teófilo Braga, Silva Pinto, Ramalho Ortigão, Eça de Queirós e Guerra Junqueiro procura-se, não só um certo saneamento literário, mas também uma regeneração cultural. Referindo-se ao escritor francês, Lopes de Oliveira chama-lhe «o mais extraordinário romancista moderno» (p. IV), na medida em que a sua luta e o seu trabalho se consubstanciam no «triunfo de uma ideia» (p. IV). Daí a homenagem justa que o mundo culto lhe tributa. Aqui uma crítica à pouca adesão que a Academia manifestou.

De salientar ainda o artigo intitulado «Bordalo Pinheiro», onde se fala do homem, da obra e do que ela representa.

Fala-se, também, de Camilo Castelo Branco e da sua obra.

Completa-se esta pequena publicação com a secção «Livros», onde se fazem apreciações aos livros que vão chegando à redacção. 


\section{0 • MEMÓRIAS DO INSTITUTO DA ACADEMIA DRAMÁTICA DE COIMBRA}

Coimbra, Imprensa de E. Trovão

1849-1852

Formato: $15 \times 22,6 \mathrm{~cm}$

Periodicidade: Não indica

Preço: Não indica

Páginas: 12 - 16
Cotas:

BN: -

BGUC: O. S. 181

BPMP: -

BMC: GHC -19/2

\section{Objectivo}

«Hoje, que a imprensa se encarregou de dar publicidade a todos os factos, vulgarizar todas as opiniões e discutir todos os assuntos, constituindo-se o registo universal da época presente; hoje, uma associação literária, que escondesse os seus trabalhos nas quatro paredes de um salão, e se esquivasse a dar as contas, que de direito todas as ilustrações devem ao público, pelo orgão da imprensa, seria uma comunidade anacrónica, e o reflexo efémero do egoísmo de outras eras...; hoje um dos primeiros deveres do homem é a ilustração, e a mais sagrada missão das associações de letras é o derramamento das luzes. Já por mais de uma vez este Instituto tem dado as devidas contas de seus actos, e derramado quanto em si cabia o cabedal dos seus conhecimentos.

Hoje, porém, que uma reforma recente nos Estatutos deu mais amplidão aos seus trabalhos, e o mais vigor e estabilidade à sua existência, constituindo-o a parte principal de uma associação, garantida pelas leis; mais estreitos são os laços, que o prendem à universal civilização, e mais larga por tanto a sua brilhante missão de ilustrar.

Enquanto não podemos, levar ao cabo a continuação das nossas publicações periódicas, que as lutas civis vieram interromper em 1846, e a que de novo meteremos ombros no princípio do próximo ano lectivo: seja-nos permitido dar começo a estas nossas Memórias, que serão o registo dos principais trabalhos literários deste Instituto, e que continuaremos a publicar irregularmente, sem embargo de qualquer outro nosso escrito periódico. 
Um dos principais deveres, que os presentes Estatutos impõe aos membros e sócios desta corporação, é honrar a memória dos sócios finados com um discurso, em seu elogio, recitado em sessão solene. Coube no corrente ano este fúnebre mister aos Senhores AntónioJoaquim Ribeiro Gomes de Abreu e Francisco de Castro Freire, em obséquio dos Senhores Henrique José de Castro e Francisco António de Melo...

Estes dois discursos formam o n. ${ }^{\circ} 1$ destas Memórias. Nós iremos publicando nos números seguintes algumas peças de literatura, que nos parecerem mais próprias deste género de publicação, os melhores trechos de poesia lírica, que se recitarem nas nossas sessões, ou no nosso teatro, e os mais discursos fúnebres, que se forem recitando, em honra dos dignos sócios finados, os Senhores - Cardeal Patriarca Saraiva, Silvestre Pinheiro, Mouzinho de Albuquerque, - e os mais, que a morte nos tem roubado» (n. ${ }^{\circ} 1$, p. 3).

\section{Conteúdo}

Como o próprio título sugere e as palavras que lhe servem de apresentação o indicam, trata-se de um periódico destinado a relatar as actividades que o Instituto desenvolve.

Apesar de se referenciar que a colecção completa deste periódico é de 4 números, conhecem-se apenas três. Referindo-se ao número em falta, Pinto Loureiro escreve: «Não mencionamos o n. ${ }^{\circ} 3$ nem o nome do sócio de quem nesse número devia ser feito o elogio histórico, porque nunca vimos exemplar algum desse número e duvidamos que ele tivesse sido publicado" (Jornais e revistas de Coimbra cit., p. 45, col. 2). Também Carneiro da Silva nos diz que «o n. 3 é desconhecido, parecendo que não chegou a ser publicado» (Ob. cit., p. 89) ${ }^{(1)}$.

Todos os números publicados têm o mesmo formato, embora o número de páginas não seja igual em todos, uma vez que o n. ${ }^{\circ} 4$ tem apenas 12 páginas.

O que há de essencial nesta publicação são os elogios históricos feitos aos sócios Henrique José de Castro, Francisco António de Melo, Luís da Silva Mouzinho de Albuquerque e Jorge Artur de Oliveira Pimentel, por António

(1) Veja-se, também, Rua Larga, n. ${ }^{\circ}$ 6, Coimbra, 1 de Novembro de 1857, p. 164. 
Joaquim Ribeiro Gomes de Abreu, Francisco de Castro Freire, António Xavier Rodrigues Cordeiro e José Freire de Serpa Pimentel, respectivamente ${ }^{(2)}$.

(2) Se foi publicado o n. ${ }^{\circ}$ 3, é possível que nele se inclua o elogio histórico ao sócio João de Vasconcelos Pereira Coutinho Mendonça Falcão, que faleceu em 1841. Este elogio teria sido proferido por Manuel Maria da Silva Bruschy (Cfr. Revista Académica, n. ${ }^{\circ} 4$, Coimbra, 1 de Maio de 1845 , p. 49, col. 1) e encontra-se publicado no n. 6 desta revista. 


\section{1・MINERVA GONSTITUGIONAL}

Periódico Semanário de Literatura e Filosofia

Coimbra, Nova Imprensa da Rua dos Coutinhos

22 Fevereiro 1823 - 10 Maio 1823
Cotas:

BN: J. 1261 B; J. 1294 P.

BGUC: R-5-13;9-(3)-17-9

BPMP: $\mathrm{M}_{4}-7-14(7)$; VR-P(A)-8

BMC: GHC-3

Redactor: José Joaquim de Almeida Moura

Coutinho ${ }^{(1)}$

Formato: 10,5 x $15 \mathrm{~cm}$

Periodicidade: Semanal

Preço: 80 réis

Páginas: 190

\section{Objectivo}

"Os déspotas tremem e o ceptro lhe cai das mãos, quando a voz da verdade lhe é dirigida pelo povo; nada tanto os aterra, que quando o povo se instrue e conhece os seus direitos; quando se lembram que a natureza os criara livres e que eles foram os mesmos que juntando-se em sociedade renunciaram tão somente aquela parte da liberdade que era indispensável para o bem geral e comum, que se há déspotas e monarcas é por sua vontade e que podem, quando o queiram, mudar a forma de governo e derrubar esses déspotas flagelos da Humanidade. É por isso que a máxima dos déspostas tem sido ocultar a verdade ao povo, opôr-se ao progresso das Luzes, plantar a hipocrisia e fanatismo e finalmente tornar tímidos os cidadãos para os impedir de levantarem o grito da liberdade. Quão diferente não é porém a máxima dos amigos da Humanidade! Estes querendo plantar a Liberdade e conservá-la aos povos, cuidam em os instruir fazendo florescer as ciências, ensinando-lhes quais são os direitos que lhe competem e as obrigações que contraíram pelo facto de se unirem em sociedade. Constituindo-se o Homem em sociedade... faz-se devedor à mesma sociedade. O seu pensar é um atributo de que está responsável à utilidade de todos. É reconhecendo a verdade deste princípio que eu publico este periódi-

(1) Em nota manuscrita no exemplar existente na B.M.C. lê-se: «Este jornal dirigido pelo estudante José Joaquim de Almeida Moura Coutinho foi escrito na cadeia académica, onde estava preso por promotor de tumultos e conflitos». 
co, para manifestar aos meus concidadãos as minhas ideias; suponho que não deixará de ser útil, porque jamais lhe saberei ocultar a verdade e esta é sempre útil. Sei que este periódico não agradará aos déspotas e que estes hão-de procurar sufocar-me, mas debalde; porque posto tenha eu sido vítima do despotismo, não o temo, e mais me esforçarei em debatê-lo por conhecer quanto são funestos os seus golpes: só ambiciono o bem da minha Pátria» (Minerva Constitucional, n. ${ }^{\circ}$ 1, Coimbra, 22 de Fevereiro de 1823, p.p. 1-2).

\section{Conteúdo}

Este periódico, escrito na cadeia académica por José Joaquim de Almeida Moura Coutinho, pretende não só afirmar e divulgar as ideias e os princípios do novo regime político instaurado em Portugal, mas também criticar e denunciar os abusos dos poderes despóticos, os inimigos e os detractores do regime constitucional. Convicto das suas ideias e propósitos, afirma: «Debalde procurais, inimigos da Liberdade, sectários vis do despotismo, sufocar em meu peito as chamas constitucionais» (n. ${ }^{\circ} 12$, p. 182). Invocando o nome da Pátria, fá-lo de uma maneira bastante irónica e humorada e, por vezes, até num discurso demasiado violento e pouco simpático, sobretudo quando em causa estão questões de educação e instrução que contrariam o espírito do século. É assim relativamente à Universidade de Coimbra e a alguns dos seus lentes. Aos professores chama-lhes, entre outros nomes, de «barbeiros» (N.o 2, p. 21) e «salamões carcovados» (n. ${ }^{\circ} 3$, p. 38), porque recusam o liberalismo e promovem a estupidez e o despotismo. A Universidade é apelidada de «Fradesca-Papal-Academia» (n. ${ }^{\circ}$ 1, p. 11).

A estrutura de Minerva Constitucional é, ao longo dos seus doze números, a mesma, quer no formato, quer no número de páginas de cada um dos números. Não havendo lugar, na primeira página, àquilo a que vulgarmente se chama «editorial» ou «artigo de fundo», este periódico é constituído por um conjunto de artigos de rubricas várias. Divulgando ideias e princípios liberais este periódico afirma-se como um órgão de carácter essencialmente doutrinário.

Nos artigos de Minerva Constitucional perpassam quatro grandes temas:

- Instrução Pública;

- Universidade de Coimbra; 
- Os inimigos do liberalismo e do constitucionalismo;

- Questões de filosofia jurídico-política

Num desdobramento mais estreito e para cada uma das temáticas é possível identificar questões como:

- Instrução Pública: necessidade e benefícios da instrução pública; os governos constitucionais e a instrução pública; a instrução pública e o poder político (críticas à Comissão de Instrução Pública; a rejeição do projecto de reforma apresentado por Santos do Vale; as posições assumidas por alguns deputados; os deputados que «fazem de monos»);

- Universidade de Coimbra: reflexões sobre a importância das ciências [(Ex.: «a Matemática constitue uma parte interessante dos conhecimentos humanos»

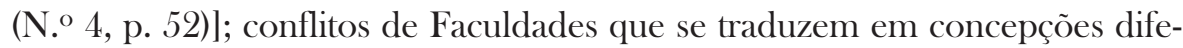
rentes de cultura e se projectam em visões diferentes do mundo e da vida: uma cultura ancestral institucionalizada nas Faculdades de Cânones, Leis e Teologia e uma cultural moderna defendida nas Faculdades de Medicina, Matemática e Filosofia (Cfr. O artigo intitulado «Tratado de Aliança ofensiva e defensiva celebrado pelas Faculdades de Cânones, Leis e Teologia aos 6 de Março de 1823", (n. ${ }^{\circ}$ 10, de 26 de Abril de 1823); necessidade de uma reforma na Universidade: "A Universidade, onde as ciências se deviam cultivar, é onde estão em maior decadência» (n. ${ }^{\circ} 7$, p. 108); críticas aos conteúdos e métodos de ensino: «os compêndios... estão cheios de princípios subversivos» e «as matérias que se estudam, longe de ilustrar a razão, não fazem senão ofuscá-la» (Idem); críticas aos mestres e às aulas que são ridículas; apelo aos legisladores para acabarem com as informações, tanto de costumes como literárias, porque são uma «terrível arma que só serve ao ódio, ao ressentimento e à vingança» (n. ${ }^{\circ}$ 10, p. $160)$.

- Os Inimigos do Liberalismo e do Constitucionalismo: Quem são os inimigos do Liberalismo? Não só os «Corcundas» que nas províncias do Norte «levantaram a voz do absolutismo» (n. o 8, p. 123), mas também «frades, padres, ministros, desembargadores e escrivães acompanhados de rendeiros e feitores de casas titulares» (n. ${ }^{\circ}$ 12, p. 178); onde se encontram? Não só no Norte, mas estão «espalhados por todo o Portugal...» (n. ${ }^{\circ} 8$, p. 123); denunciam-se alguns (Luís de Melo Machado Fastio, prior do Souto de Lafões, Manuel de Oliveira Novais, abade de S. Vicente e José Viçoso da Veiga, prior e professor de primeiras letras em Oliveira de Frades), porque é obrigação de todo o cidadão dever denunciar os inimigos da liberdade; estratégias destes homens: «trabalhar em fazer prosélitos, desapreciar o sistema constitucional e macular a honra dos 
verdadeiros constitucionais» (n. ${ }^{\circ}$ 11, p. 175); necessidade de formar uma nova opinião pública; estar atento a possíveis golpes de Estado.

- Questões de filosofia jurídico-política: A quem compete a interpretação das leis? O problema da pena de morte num estado; o problema do abuso do poder e da violação das leis constitucionais.

Bibliografia: Luís Reis Torgal, «A imprensa estudantil em Coimbra e o radicalismo liberal vintista», $O$ Liberalismo na Península Ibérica na primeira metade do século XIX, (Coordenação de Miriam Halpern Pereira, Maria de Fátima Sá e Melo Ferreira e João B. Serra, 2. ${ }^{\circ}$ Volume, Lisboa, Sá da Costa Editora, 1982, p.p. 241-56; Luís Reis Torgal e Isabel Nobre Vargues, A revolução de 1820 e a instrução pública, Porto, Paisagem Editora, 1984, p.p. 275 e ss. 


\section{2・ O MINHO}

Coimbra, Imprensa da Universidade

11 Março 1862 - 27 Maio 1862

Colaboradores: A. C. de Sousa Geão, M. J. Correia

Veloso, A. Lopes, A. R. de Sousa e Silva, José

Liberato Freire de Carvalho, Rodrigo de Menezes,

C. Fontes, Rodrigo Veloso, José Pedro da Silva e

Cerqueira Lobo

Formato: 32 x $47 \mathrm{~cm}$

Periodicidade: Semanal

Preço: Trimestre - 500 réis

Páginas: 4
Cotas:

BN: J.282 M.; J.725//24A.

BGUC: $\mathrm{B}-18-39-6$

BPMP: P/C/1074

BMC: GHC $-21 / 6$

\section{Objectivo}

"Aí está o Minho. Intérprete fiel dos votos e aspirações dos estudantes que se viram subir de meninos a esperançosos nas margens de tantos rios que serpenteiam por esse rubi de Portugal; O Minho não milita debaixo das bandeiras que hoje por aí tremulam ao sopro abrasador de prélios feridos!

Seguirá outra rota; navegará outros mares... A política... nunca maculará as páginas deste papel, que vive de outra seiva e que aspira a outros mundos...

Este papel dormirá pouco, mas descansará no regaço da paz: levantar-se-á cedo, verá as estrelas próximas a banharem-se na púrpura da manhã e, ainda esfregando os olhos, irá bater à porta da cidade, da vila, da aldeia, ao mármore do rico, ao palhal do pobre, irá, repito, perguntar como se contam aí as necessidades e que feições a distinguem.

Esfolinhará alguns preconceitos que por lá, por essa província, se enraízam e depauperam tantas plantas formosas, tantas campinas ridentes.

Estinhará a colmeia das boas ideias que por esse mundo arfam, como poeira dourada, à cata duma cabeça onde frutifiquem e donde sejam atiradas ao cachão do progresso!

O incitamento é tudo...

O estipêndio do nosso trabalho só é a benção dos nossos amigos, das nossas famílias, das nossas mães - eis o nosso fito, a nossa ambição, a nossa esperança. 
Vai querido papel... Religião, Deus, Amor, Pátria - eis o nosso credo, o nosso ofir, o nosso Cristo...» (n. ${ }^{\circ}$ 1, p. 1).

«Sinceramente devotado ao mais amplo florescimento daquela abençoada província, daquele formoso jardim de Portugal, há-de conquistar os foros da estima pública e erigir um padrão, que ateste, e, por assim dizer, perpétue os brios e o patriotismo da actual geração académica.

No grandioso apostolado da imprensa, não só propugnará pelos interesses e melhoramentos materiais, senão também evangelizará os mandamentos da instrução popular...

Estranho, na sua missão, aos certames facciosos da política - cremos que o Minho ainda assim poderá prestar valiosos serviços à causa pública, cooperando com as suas forças para o engrandecimento, assim material, como moral, da sua província» (n. ${ }^{\circ}$, p. 1, col. 1).

\section{Conteúdo}

Este pequeno periódico, órgão de um agrupamento de estudantes minhotos, procura contribuir, não só para o bem da causa pública, em geral, mas também para o desenvolvimento material e espiritual da província do Minho, em particular.

A estrutura interna deste periódico é sensivelmente a mesma, ao longo dos doze números que compõem a colecção. Apenas o n. ${ }^{\circ} 5$ tem mais um suplemento de duas páginas, onde se publicam os Estatutos da Sociedade do Minho.

De uma maneira geral, uma boa parte da primeira página é dominada por um artigo de fundo, onde os seus responsáveis reflectem sobre temas vários, nomeadamente: instrução popular; melhoramentos materiais para a província do Minho; imagens físicas e humanas do Minho; necessidade de reformas no sistema prisional português; Academia e Liberdade e outros de menor monta.

Ao artigo de fundo seguem-se, depois, um conjunto de textos e rubricas várias, onde se podem destacar questões como: necessidade de uma nova instrução para ao clero; caixas económicas e questão social; saúde pública (críticas ao enterramento nas igrejas, a necessidade de construção de cemitérios); jurisprudência (a necessidade de uma reforma administrativa, considerações sobre o código Penal Português); contributos históricos (para a história da cidade de Guimarães e para a ciência da metrologia). 
Embora não com um carácter totalmente permanente, assinalam-se secções que aglutinamos como: «Correspondência/Interior. Ponte da Barca, Vila do Conde e Porto», onde se relatam e dão a conhecer notícias e acontecimentos vários ocorridos nestas localidades, nomeadamente na cidade do Porto como: questões camarárias, Academia Politécnica, Grémio Literário Portuense, instituições bancárias, imprensa portuense, etc.),; «Noticiário/Crónica. Coimbra», com notícias diversas sobre a Academia, a cidade e outras regiões. De salientar, aqui, a notícia de um sarau de poesia, no Teatro Académico, onde «pela vez primeira apareceu a recitar no seio da academia a simpática e talentosa poetisa Amélia Janny» (n. ${ }^{\circ}$ 9, p. 4, cols 2 e 3); «Esboço Corográfico das principais povoações do Minho", espaço reservado a «algumas descrições das terras mais importantes do nosso Minho, adoptando como termómetro avaliador de tal importância, todas as cabeças de comarca segundo a nova divisão judicial» (n. ${ }^{\circ}$ 1, p. 2, col. 1). Aqui se apresentam elementos relativos a Valença, Barcelos, Vila Nova de Famalicão, Guimarães, Ponte de Lima, Celorico de Basto e Arcos de Valdevez. Sendo a província do Minho uma terra onde a actividade agrícola ocupa um lugar privilegiado, não admira que no jornal nos apareça uma secção dedicada a esta questão. Esta secção intitula-se mesmo «Agricultura». Da autoria de M. J. Correia Veloso, para além de considerações gerais sobre a matéria, aqui se reflecte não só sobre a sua importância, porque ela é «a verdadeira origem do manancial fecundo do tesouro, e como tal, devem os governos promover o seu ensino popular» (n. ${ }^{\circ} 5$, p. 3, col. 1), mas também se reconhece o nosso atraso, ao mesmo tempo que se propõem soluções para um melhoramento do sistema agrário. Defende-se, também, a arborização das nossas costas, na medida em que «a plantação de árvores é absolutamente necessária, é um grande meio higiénico, já pela sua influência no clima que refresca, como pela absorção dos miasmas ou matérias orgânicas, que viciam o ar, convertendo elas esse mal em produtos úteis» (n. ${ }^{\circ}$ 9, p. 3, col. 2).

Neste periódico, verifica-se a existência, muito efémera, de uma rubrica intitulada «Política Estrangeira», onde se reconhece a necessidade de os homens conhecerem o seu tempo, sabendo o que se passa além fronteiras e outra «Notícias Estrangeiras», com notas e informações sobre o que se vai passando em vários países.

De anotar, também, a rubrica «Variedades», onde se fornecem informações sobre o estado financeiro do país, no tempo do rei D. João V, e se reproduz, traduzida do francês, a fábula «O poeta, o cérebro, a pena e o tinteiro». 
Completa-se este periódico com os habituais folhetins, alguma poesia, textos de natureza moralizante e publicidade, sobretudo de publicações literárias.

De anotar ainda, no n. ${ }^{\circ} 12$ do jornal, uma referência muito especial para os caloiros, num texto com 12 quadras intitulado «Estatutos da lei secreta. Dirigidos à novilhada». 


\section{3 - A MINIATURA}

Jornal literário e científico

Cotas:

Coimbra, Tip. França Amado

2 Fevereiro 1896 - 29 Maio 1897

BN: P.P. 5825 P.

BGUC: -

BPMP: -

BMC: GHC $-19 / 2$

Redactores: Luís de Castro, Alberto Bastos, Carlos

Geraldes e João de Barros ${ }^{(1)}$

Formato(s): 13 x $19,7 \mathrm{~cm} \bullet 9 \times 13,5 \mathrm{~cm}^{(2)}$

Periodicidade: Quinzenal

Preço: Mês -50 réis $\bullet$ Avulso -30 réis

Páginas: 8 - $16^{(3)}$

\section{Objectivo}

«Surge da massa dos impossíveis sem antecipados reclames, sem prévios elogios, como Minerva saiu da cabeça de Júpiter.

Não promete nada para a nada faltar, e um belo dia morrerá como tudo o que nasce. É este o seu programa, o seu objecto, o seu princípio e o seu fím. Nada mais» (A Miniatura, n. ${ }^{\circ}$ 1, p.1).

\section{Conteúdo}

A Miniatura é uma pequena e modesta publicação levada a cabo por alunos do liceu e cuja colecção completa é de treze números, sendo os dois primeiros litografados e os restantes impressos.

(1) Em Os Novos, n. ${ }^{\circ}$ 1, 4 de Dezembro de 1896, p. 8, lê-se: «Vicente Pinheiro de Melo e Fausto de Quadros, fundadores e antigos redactores de "A Miniatura", declaram ter-se completamente desligado da redacção daquela revista por motivos que não carecem vir a público».

(2) Os dois primeiros números são litografados.

(3) «Tinhamos prometido aos nossos leitores que o nosso jornal teria 16 páginas... Foi, porém, impossível arranjar isso, e sai com 8 páginas em $8 .^{\circ}$, o que vem dar na mesma». (A Miniatura, n. ${ }^{\circ}$ 1, p. 8). Alguns números foram, no entanto, publicados com 16 páginas. É, o caso do n. ${ }^{\circ} 11$, de 11 de Fevereiro de 1897 . Também os n. ${ }^{\circ s} 5$ e 6 têm 16 páginas, mas foram publicados em conjunto. 
Apesar de os seus responsáveis não adiantarem qualquer tipo de programa, este periódico define-se como um jornal literário e científico.

Repartidos por vários números, mas de interesse bastante modesto, a maior parte das páginas deste periódico são preenchidas com pequenos textos literários, em prosa e em verso. No âmbito do literário, de assinalar, também, textos referentes a figuras da vossa literatura. É o caso da evocação que fazem da figura do poeta João de Deus.

Lugar, também, para temáticas científicas com textos como «Química Recreativa. Colorização das flores pelo amoníaco» e "Ciências Naturais. A semelhança protectora e o mimetismo no reino animal», de Carlos Geraldes, entre outros.

Na secção «Pelo Lyceu» fornecem-se informações várias da escola e da academia. 


\section{4・MOSAICO}

Folha Quinzenal, Literária e Científica ${ }^{(1)}$

Coimbra, Imprensa Académica

Dezembro 1874 - Abril 1875
Cotas:

BN: J. 179//8 B.; J. 453//4 M.; BGUC: J. $1665 / / 5 \mathrm{~V}$.

BPMP: IX - 2 - 118

BMC: GHC $-20 / 8$

Colaboradores: Manuel Emídio Garcia, Magalhães Lima, Macedo Papança, Silva Ramos, Sérgio de Castro, Augusto da Fonseca, Emídio de Oliveira, Gomes Leal, Augusto Rocha, Bettencourt Rodrigues, Álvares de Azevedo, Augusto Ramos, Nunes da Ponte, Amélia Janny, Adelino das Neves e Melo, Barros de Seixas, Paulo de Andrade, Cesário Verde, J. Simões Dias, Coelho de Carvalho, Júlio César Machado, Barbosa de Magalhães, João de Sousa Araújo e outros

Formato: 23 x $31 \mathrm{~cm}$

Periodicidade: Quinzenal

Tiragem: 1.000

Preço: Trimestre -360 réis $\bullet$ Avulso - 60 réis

Páginas: 72

\section{Objectivo}

«Entramos no combate. Chegamos de longes terras: percorremos a vida do Oriente, os nevoeiros do norte e o spleen do inglês.

Temos o amor sereno e o amor irritante; trazemos a violeta modesta para as damas de olhar negro, que nos levam aos abismos profundos da loucura, e o punhal agudo e fino da nossa ironia para os grandes ridículos das cenas da vida...

Não fazemos programa pomposo.

Em nossos corações há templos para o amor, e por isso cantaremos a formosura.

Sem poses estudadas, e com a singela ingenuidade do namorado português, ofertaremos às leitoras a camélia branca e setinosa, que lhes enfeite as negras

(1) O n. ${ }^{\circ} 1$ desta publicação tem apenas como subtítulo «Folha Quinzenal». 
tranças, o jasmin que as embriague de aromas, e sobre tudo o nosso braço forte, que não duvida ressuscitar os belos tempos de Magriço, em troca de haver um Camões que nos cante as façanhas...

E para vós, cavalheiros, sérios impassíveis, que nos ledes depois de jantar, saboreando com o café a nossa prosa e os nossos versos, levaremos o haschich das loucas fantasias, que há-de elevar-nos a imaginação como o champagne em copos de cristal, e depois serená-la docemente como o sono a descer sobre as pálpebras de uma virgem de Murillo.

Em troca de tudo isto - do céu e da terra, do amor e das torturas, da liberdade e da justiça - pouco pedimos: de vós, leitoras, o sorriso que nos inspire; e dos cavalheiros, a amável companhia pelos caminhos do ideal» (n. ${ }^{\circ}$ 1, Dezembro de 1874 , p. 1).

\section{Conteúdo}

Mosaico é uma pequena publicação estudantil que, à semelhança de muitas outras, aposta numa divulgação literária e científica, com o intuito de ilustrar e sensibilizar.

A estrutura desta publicação é, quanto ao formato e número de páginas de cada número, a mesma, nos nove números que compõem a colecção. Internamente, a primeira página é, de uma maneira geral, dedicada ao artigo de fundo, ao qual se seguem outros textos e outras rubricas.

Ainda ao nível da estrutura interna, de salientar a existência de uma secção permanente «Factos», uma espécie de crónica dominada, fundamentalmente, pelos acontecimentos, pelas notícias e algumas curiosidades que se vão passando em Coimbra. De referir, também, a «Secção Bibliográfica», que durou até ao n. ${ }^{\circ}$ 5, onde se dá conta, não só das publicações que iam sendo dadas à estampa, mas também de uma apreciação das mesmas.

É, sobretudo, ao nível dos artigos de fundo que perpassam as grandes temáticas, onde se descortinam as simpatias ideológicas da publicação. É aqui que se reflecte e se tecem considerações várias sobre questões como: educação; a igreja e o estado; as contradições políticas no seio do liberalismo; a questão do federalismo; a importância do jornalismo e saúde pública - os cemitérios. De salientar referências à história da Espanha e da Alemanha. 
Um lugar, também, para o mundo da arte. Se Emídio de Oliveira, em dois pequenos artigos, nos fala de arquitectura, é sobretudo Augusto Ramos quem, no artigo intitulado "Crítica Artística. A exposição trienal da Academia portuense de Belas-Artes», nos tece considerações várias sobre este evento e o movimento artístico no nosso país.

Completa-se esta publicação com textos literários, em prosa e verso. 


\section{5 • NEM CÁ NEM LÁ}

Coimbra, Imprensa Académica

Fevereiro 1889 - 18 Março 1889
Cotas:

BN: J. 1060 B.; J.1651//18V

BGUC: -

BPMP: -

BMC: GHC $-20 / 2$

Redactores: Pinto da Rocha e Ernesto de Vasconcelos

Colaboradores: Alguém, Beltrano, Cicrano, Eu, Ele, Fulano, Ninguém, Qualquer de nós, Tu

Formato: 27,5 x 20,5 cm

Periodicidade: Mensal

Preço: Avulso - 30 réis

Páginas: 16

\section{Objectivo}

«Não vamos preencher lacunas, porque não é nosso costume tapar buracos, seja qual for a sua natureza.

Somos peripatéticos. A nossa redacção é ao ar livre, e a administração por toda a parte onde se venda a nossa gazeta.

Somos intransigentes com tudo e com todos. O nosso destino é dar pancada a torto e a direito tanto na Boémia Nova, como nos Insubmissos. Agrada-nos esta posição, independente e misteriosa. Não é medo que nos obriga a guardar o rigoroso incógnito, é a modéstia natural, própria dos espíritos ilustrados e inteligentes. Não deixaremos por mãos alheias o nosso crédito, da mesma forma que seremos desapiedados com aqueles que nos insultarem...

A nossa vida está dependente da vida da Boémia Nova e da vida dos Insubmissos...

Durante a nossa existência tencionamos ser implacáveis na execução da justiça, e arvorando o estandarte vermelho da revolta na torre do nosso ideal artístico..., seremos verdadeiros Boémios da mocidade, amantes da gargalhada..., os Insubmissos gloriosos deste batalhão de demagogos, e os iconoclastras sublimes, evangelizadores do riso, apóstolos da troça limpa e delicada...

Para isso, a nossa redacção, como as barracas de campanha, assentará onde houver um ridículo, que nos forneça uma ironia.

$\mathrm{Na}$ bagagem que trazemos, modesta e simples como convem aos nómadas da literatura, há o telescópio com que iremos devassar o céu-azul das aspira- 
ções dos Insubmissos, e o escafandro com que desceremos a sondar o mare magnum da ciência da Boémia Nova» (Nem Cá Nem Lá, n. ${ }^{\circ}$ 1, Fevereiro de 1889, p. 1).

\section{Conteúdo}

Este periódico, de sátira estudantil bem humorada, insere-se naquele tipo de jornalismo académico ou de literatura que nós classificamos como de escárnio e maldizer. Nem Cá Nem Lá, como os seus próprios redactores referem, tem muito a ver com as revistas Boémia Nova e Insubmissos. É que, em 1889, estes periódicos disputavam a primazia da introdução de novas experiências rítmicas e estilísticas, fazendo, também, grande alarde dos nomes então na ribalta nas letras francesas. Estas inovações foram acolhidas com muito escárnio, não só pelo público, mas também pelos críticos. Daí as inúmeras referências e transcrições que Nem Cá Nem Lá faz, quer da Boémia Nova, quer de Insubmissos.

Concluindo, diremos que no artigo com o título «Os Degenerados», Pinto da Rocha opina, em linhas genéricas, sobre o modo e as condições em que aparecem e desaparecem os periódicos, em Coimbra. Referindo-se à geração deste tempo escreveu: «Utilizamo-nos simplesmente desse título (Os Degenerados) para acompanhar o nosso trabalho de antropologia patológica, em que estudaremos o estado mórbido da moderna geração literária que enxameia no nosso pequeno meio» (n. ${ }^{\circ}$ 2, 18 de Março de 1889, p. 10). 
86 - O NOVO TROVADOR (1)

Colecção de poesias contemporâneas

Coimbra, Imprensa de E. Trovão

1851-1856

Colaboradores: Alexandre Braga, Alfredo de Carvalho, António Aires de Gouveia, A. A. Soares de Passos, A. P. da Cunha, A. X. R. Cordeiro,

F. Palha, Guilhermino Augusto, J. Freire de Serpa Pimentel, J. de Lemos, J. S. Costa Lima, J. X. V.

de S. e J. S. da Silva Ferraz

Formato: 13 x $21 \mathrm{~cm}$

Periodicidade: Não indica

Preço: Não indica

Páginas: 208 + Índices
Cotas:

BN: J. 1312 B.; J. 2417 P; P.P. $22990 \mathrm{~V}$;

BGUC: -

BPMP: -

BMC: GHC -2

\section{Objectivo}

Não indica

\section{Conteúdo}

É um periódico constituído, única e exclusivamente, por poesia.

(1) Segundo Carneiro da Silva, esta publicação foi promovida pelo estudante António Aires de Gouveia. Composto por 12 números, este periódico forma um volume com 208 páginas mais índice, onde não se diferencia o início e o fim dos exemplares. Estes identificamse, porque, no canto inferior direito, nos aparece o número do exemplar e, no inferior esquerdo, o nome da publicação.

Para além dos colaboradores, no periódico não são indicados outros elementos. Os dados aqui reproduzidos foram recolhidos da obra de Carneiro da Silva, Jornais e revistas..., p. 97. Veja-se também Alberto Sousa Lamy, A Academia de Coimbra (1537-1990). História. Praxe. Boémia e Estudo Partidas e Piadas. Organismos Académicos, Lisboa, Rei dos Livros, 1990, p. 99. 


\section{$87 \cdot$ OS NOVOS}

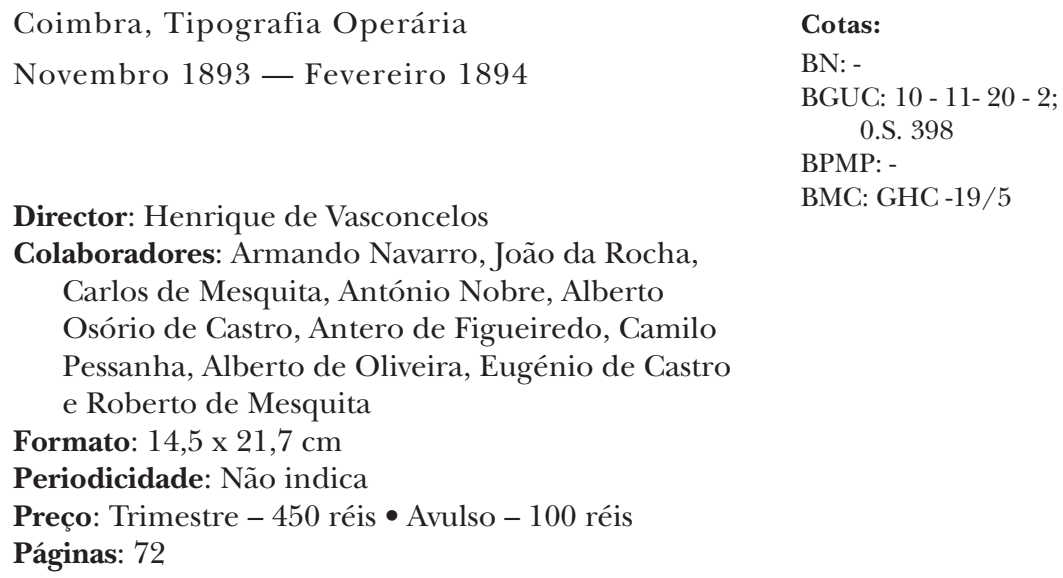

Director: Henrique de Vasconcelos Cotas:

BN: -

BGUC: 10 - 11- 20 - 2; O.S. 398 BPMP: -

BMC: GHC $-19 / 5$

Colaboradores: Armando Navarro, João da Rocha, Carlos de Mesquita, António Nobre, Alberto Osório de Castro, Antero de Figueiredo, Camilo Pessanha, Alberto de Oliveira, Eugénio de Castro e Roberto de Mesquita

Formato: 14,5 x 21,7 cm

Periodicidade: Não indica

Preço: Trimestre -450 réis $\bullet$ Avulso -100 réis

Páginas: 72

\section{Objectivo}

Não indica

\section{Conteúdo}

Apesar de esta publicação não indicar a razão e os objectivos do seu aparecimento, não custará muito a admitir que ela se propõe cultivar e divulgar a nova estética literária. Este propósito poderá ajudar-nos, também, a compreender a título adoptado.

Trata-se de uma pequena revista literária de que se publicaram apenas quatro números. A par de alguma criação literária, em prosa e verso, compulsada de livros inéditos e a entrarem no prelo, merece uma referência especial o artigo intitulado "Dos novos e da sua poesia», repartido pelos três números da revista, da autoria de Armando Navarro, onde este colaborador discorre sobre estética literária, evolução das formas poéticas e das relações da filosofia com a literatura. A este propósito escreveu: «O modo de sociedade actual, as suas crenças, a sua moral profundamente egoísta, a falta de unidade mental, a decadência progressiva dos caracteres, a mórbida inconsistência das vontades, todo este 
desfazer da nossa velha raça não são de molde à produção das obras fortes e simples das literaturas clássicas» (n. ${ }^{\circ} 2$, p. 25$)$.

De salientar, também, o estudo da responsabilidade de Carlos de Mesquita, e que este intitulou de «Jerónimo Freire», onde se apontam aspectos importantes do novo gosto literário.

Bibliografia: Fernando Guimarães, Simbolismo, Modernismo, Vanguardas, Porto, Lello \& Irmão Editores, 1992, p. 231. 


\section{$88 \cdot$ OS NOVOS}

Revista de Literatura, Ciência e Recreio

Coimbra, Typ. França Amado

4 Dezembro 1896 - 6 Março 1897
Cotas:

BN: J.974//12 P.; J.1611//3 B.

BGUC: -O.S 605

BPMP: -

BMC: GHC $-19 / 2$

Redactores: Vicente Pinheiro de Melo ${ }^{(1)}$ e Fausto de Quadros

Colaboradores: Adolfo de Azevedo, Bento de Lencastre

Formato: $11,5 \times 19 \mathrm{~cm}$

Periodicidade: Não indica

Preço: Não indica

Páginas: 8

\section{Objectivo}

«Não nos conformando com praxes e velharias, detestando tudo quanto seja convenção ou costume estabelecido, não vimos aqui fazer a nossa apresentação. E se tentássemos fazê-la... havíamos de dizer que o nosso jornal vinha preencher uma lacuna... vinha levantar o nível intelectual... vinha pôr os leitores ao facto do movimento literário e científico da actualidade... e outras frases de estrondo...

Em seguida apresentaríamos mil prometimentos pomposos... Pois nada fazemos assim. Trocamos as galas e louçainhas da retórica, os primores e belezas do estilo, os períodos longos e as frases de efeito pela maior e mais completa simplicidade.

Os Novos é um jornal de rapazes. É uma brincadeira de estudantes que procuram nas lides da pena um meio útil de suavizar as fadigas da vida académica...

Como se vê, não temos pretensões. Vivemos conscientes da nossa pequenez, mas vivemos, porque os pequenos também têm direito à existência, à vida e à luz...

(1) Segundo informação colhida na própria publicação, Vicente Pinheiro de Melo, apesar de redactor, não chegou a colaborar (Cfr. n. ${ }^{\circ} 2$, p. 8). 
Com esta franqueza e com esta simplicidade aguardamos a benevolência dos nossos estimáveis leitores. E nada mais» (n. ${ }^{\circ} 1$, 4 de Dezembro de 1896, pp. 1-2).

\section{Conteúdo}

Sem um programa concretamente definido, mas com uma intenção de aliviar as mentes das lides do estudo, este pequeno e modesto periódico de alunos do liceu, que não passou do segundo número, para além de temáticas literárias, aborda, de uma maneira simples e rápida, tudo em sintonia com a idade dos seus autores, questões importantes da sociedade: a questão social e o problema do suicídio. Aquela é entendida, não como uma simples questão entre o capital e o trabalho, mas como algo de mais complexo: como uma questão de direito, de moral, de educação, de filosofia, de política e de cultura. Daí os apelos à moralização, à família que não deve deixar que, entre ela, se estabeleça a discórdia com «uma propaganda de doutrinas corruptoras» e à escola, onde «não se crie a anarquia incutindo ideias subversivas» (n. ${ }^{\circ}$ 1, pp. 3-4).

O suicídio, que, ontem, era encarado como «o epílogo do romance dum coração despedaçado ou a catástrofe duma grande tragédia de protagonista heróico...» é, hoje, visto como «uma moda sinistra..., derradeira estroinice duma vida desregrada, último acesso de uma neurose fatal» (n. 2 2, p. 5, col. 1). Daí, também, a chamada que estes jovens jornalistas fazem à imprensa, para banirem das suas colunas notícias tão funestas.

No domínio dos temas literários, a par de uma certa produção, em prosa e verso, reflecte-se sobre literatura finlandesa nomeadamente sobre a vida e obra de dois autores de contos: Runcherg e Pãivärinta.

Completam este periódico breves notícias do Liceu, algumas curiosidades e passatempos. 


\section{9 • O PALITO}

Orgão da «República Cubana»

Coimbra, [s.1.]

26 Abril $1896^{(1)}$ - 29 Maio 1896
Cotas:

BN: J. 968//30 P.; J. 1395 B.

BGUC: -

BPMP: IX - 5 - 9

BMC: GHC -4

Redactores: Gil Vaz e Companhias

Colaboradores: Álvares de Moura

Formato(s): 16 x $20 \mathrm{~cm} \bullet 20 \times 28,5 \mathrm{~cm}$

Periodicidade: Não indica

Preço: Mês -80 réis

Páginas: 4

\section{Objectivo}

«Sicut post jantarem opiparum usantur palito ad desaffrontandos dentes et non fazendum stercum porcariamque in queixis: ita in medio stofadelarum, aporrinhationumque vel colicarum propter aulas debet usari Palitus consolatorius ad rapaziatam divertendam, ad rire faciendam in despregatas bandeiras et esgravatandum taedium.

Assim diz o Palito Métrico, esse livro que vem sendo desde tempos recuados o código fundamental da Academia, o Evangelho, digamo-lo assim, de todo o estudante coimbrão.

Mas o nosso Palito não é apenas métrico. Bem sabemos que se assim fosse só poderia servir de recreio a uma diminuta parte dos nossos colegas, a esses que têm a ventura de possuir as musas por cozinheiras, por quanto, todos os que não cultivam a poesia, por via de regra, embirram com ela.

É por isso que o nosso Palito não é apenas métrico.

Mira a um escopo mais nobre, mais elevado: não a preparar um pitéu à altura de todos os estômagos sociais, como diria qualquer irmão-unido, mas a espevitar todas as dentaduras desde as mais alvas e microscópicas, fazendo lembrar perolazinhas de Ofir, até às mais gigantescas e esfumaradas, semilhando

(1) Certamente por lapso, Carneiro da Silva indica a data de 4 de Abril para a publicação do $1 .^{\circ}$ número (Ob. cit., p. 100). 
ameias de um castelo medieval. É pois duplo e seu fim; é também prosaico: duplex dos est.

Numa outra coisa difere o nosso jornal do Palito a que aludimos: não rirá somente; saberá também portar-se sério, quando as circunstâncias assim o exigirem.

Esta folha é destinada além disso a ser o orgão da República Cubana. Não vão pensar agora que ela tem em vista advogar quaisquer ideias políticas mais ou menos avançadas; não. É, todavia, certo que, no momento actual em que a questão de Cuba tanto agita os espíritos de todo o mundo, não duvidamos adoptar esse nome para a nossa república académica, exprimindo assim, em que pese aos nossos vizinhos espanhóis, a simpatia que nos inspira a causa sublime da independência de um povo» (O Palito, n. ${ }^{\circ}$ 1, Coimbra, 26-IV-96, p.p. 1-2).

\section{Conteúdo}

Este pequeno jornal, organizado pelos estudantes da República Cubana, pretende não só fazer rir, mas também cultivar um pouco as letras, nomeadamente a poesia.

Com ilustrações ao nível do cabeçalho, mas diferentes de número para número (Torre da Universidade e parte dos gerais, Porta Férrea, Monumento a Camões e, possivelmente, um trecho do Museu Machado de Castro, respectivamente), esta publicação não passou de quatro pequenos números litografados.

Embora o n. ${ }^{\circ} 4$ não tenha o formato dos outros, porque maior, a estrutura interna desta publicação é, sensivelmente, a mesma. De conteúdos relativamente modestos, a primeira página é preenchida por pequeníssimos textos alusivos a assuntos académicos: o dia de ponto na Faculdade de Direito, récitas de despedida e emancipação dos caloiros.

A existência de secções permanentes como: «Flores Dispersas», espaço totalmente dedicado à poesia e "À Gandaia», onde, também, a par de alguma métrica, se contam casos divertidos passados com professores.

À semelhança de outros, informa, igualmente, das publicações recebidas. 


\section{0 - O PANORAMA GONTEMPORÂNEO}

Coimbra, Imprensa da Universidade

1 Novembro 1883 - 15 Abril 1884

Director: Trindade Coelho

Colaboradores: Alexandre da Conceição, Guerra Junqueiro, Luís Osório, Camilo Castelo Branco, J. Leite de Vasconcelos, F. Martins Sarmento, A. A. da Fonseca Pinto, Abílio de Lobão Soeiro, A. R. Gonçalves Viana, A. R. Nogueira, Oliveira Ramos, Eugénio de Castro, F. Correia Mendes, J. G. de Barros e Cunha; Amélia Janny, Costa Macedo, Lopo de Castro e outros

Formato: 26 x $33 \mathrm{~cm}$

Periodicidade: Quinzenal

Preço: Trimestre-750 réis • Avulso-200 réis

Páginas: 8
Cotas:

BN: J.243//11 M.; J. 879//2B.; J. 1666//22V.; J.2450//21V P.P. 3801A. BGUC: $10-7-18$ BPMP: P/B/ 3122 BMC: -

\section{Objectivo}

«... este jornal... pode formar com o tempo magníficos volumes de incontestável merecimento, através dos quais o nosso país desfile triunfalmente, a todo o porte de velha majestade respeitável. Artisticamente, o nosso jornal será aprimorado e elegante...

Literariamente, confiamos no talento e boa vontade dos escritores que nos auxiliam e que têm nome feito na literatura, uns, e nas academias como homens de ciência, outros» (n. ${ }^{\circ} 1$, Coimbra, 1 de Novembro de 1883, p. 3).

"A evolução das sociedades criou aspirações novas. A tendência do nosso século é manifesta. Avançamos para a ciência, fascinados pela vertigem que dá a contemplação mais nítida da verdade. Para disseminar o novo credo, criou-se a vulgarização, a evangelização, o apostolado da ciência. Hoje que a ciência não é um fruto proibido, assistimos a esta orgia imensa de ideias, que o espírito cosmopolita da época absorve vorazmente...

Os vulgarizadores inábeis caem frequentemente neste erro: exporem a ciência dum modo elevado para os que não sabem, e supérfluo para os que estudam. Desta forma a ciência não aproveita a ninguém. Para isso é preciso, pungi-la, quanto possível, do arsenal técnico, do aparato severo que cinge a ideia 
na forma, da aridez nua sem prejuízo da verdade. É, o que vamos tentar nesta secção, na qual procuraremos no limite dos nossos recursos, atingir o ideal formulado por Goethe: unir o belo à verdade» (n. ${ }^{\circ}$ 6, Coimbra, 15 de Fevereiro de 1884, p. 47).

\section{Conteúdo}

Com uma estrutura estável ao longo dos diferentes números, uma das principais linhas de força deste periódico é a ideia de progresso. Comungando na ideia vinda já do iluminismo e do primeiro romantismo, de que a cultura tinha uma função emancipadora e não desconhecendo que a grande maioria do povo português se achava distante do nível geral de cultura, neste periódico procura-se divulgar o maior número de temas e de questões, para ilustração do público. Foi nesta perspectiva que A. R. Nogueira, no seu artigo «Universidade», escreveu: «Percorrendo a história das nações encontramos sempre uma relação íntima entre o seu desenvolvimento intelectual e o aumento de riqueza... A ilustração é uma das condições indispensáveis para o progresso material dos povos» (n. ${ }^{\circ} 5$, Coimbra, 1 de Fevereiro de 1884, p. 33). Daí a divulgação de estudos e assuntos vários do domínio das Ciências da Natureza, como, por exemplo, «As Bellezas da Sciencia. O Sol, origem da vida»; «Da água como agente natural, sua influencia physica, chímica, etc»; «Da água como agente industrial ou económico», mas também de temáticas ligadas a História de Portugal como, por exemplo, os textos de F. Martins Sarmento sobre os castros; sobre Língua Portuguesa de que citamos os ensaios de J. Leite de Vasconcelos intitulados «Onomatologia Portugueza» e de A. R. Gonçalves, «Estudos de Língua Portugueza. Léxico» e ainda de Arte como o de A. R. Nogueira sobre o Mosteiro do Lorvão.

Completam este jornal descrições sobre a cidade de Coimbra e seus arredores e ainda um conjunto grande de poesias.

Bibliografia: Trindade Coelho, In Illo tempore..., pp. 74 e ss. 


\section{1・ A PÁTRIA}

Coimbra,Tip. e Lit. Minerva Central

20 Janeiro 1897 - 30 Janeiro 1898

Director: Hermínio da Silveira

Administrador: Mário Leite Ribeiro

Redactor: Fernando Pimentel

Secretaria da Redacção: Henrique de Carvalho

Colaboradores: Rita da Silveira e Raimundo Correia

Formato: 17 x $23 \mathrm{~cm}$

Periodicidade: Bimensal

Preço: Trimestre -120 réis

Páginas: 4
Cotas:

BN: J.333//6P.; J.968//33P.

BGUC: -

BPMP: -

BMC: GHC $-19 / 5$

\section{Objectivo}

«Ao apresentarmo-nos ao público cumpre-nos fazer-lhe a declaração: - de que este jornal não tem política definida; que vem hoje à publicidade única e exclusivamente para defender os progressos morais e materiais desta cidade e seu distrito; que não reconhece outra política que não seja aquela que se basear na verdade - eminentemente patriótica.

Desligados de preconceitos que a civilização moderna condena, hoje em dia, como coisa obsoleta e portanto fora do sentir e corrente geral, como é a chamada - questão religiosa - a qual tem ultimamente agitado a opinião de um extremo ao outro do país, pela propaganda tenaz que se tem espalhado, sem robuço, contra os sentimentos liberais desta bela terra portuguesa; desligados, igualmente, da política pouco airosa e nada limpa em que andam tantos e tantos homens que melhor fora que a abandonassem para seu crédito e honra do país, que é, afinal, o que mais tem sentido os seus terríveis efeitos dia a dia... nós, repetimos, também não estamos ligados a qualquer dos partidos políticos...

Eis, pois, qual o nosso caminho de independência, traçado à existência deste humilde jornal que hoje vê a luz da publicidade, sem compromissos de espécie alguma, com quem quer que seja, nem com outras ambições que bem servir a nossa muito amada e querida Pátria, a qual serviu para nome do jornal...» (n. ${ }^{\circ}$, Coimbra, 20 de Janeiro de 1897, p. 1). 


\section{Conteúdo}

Trata-se de um jornal elaborado por alunos do Liceu, «cuja idade circunferenciava pelos 12 anos» (A Pátria, n. o 24, Coimbra, 30 de Janeiro de 1898, p. 1). Afirmando-se independentes em política, as suas preocupações centram-se, essencialmente, em «bem servir a nossa muito amada e querida Pátria», em geral, e em defender os progressos morais e materiais da cidade de Coimbra e do seu distrito, em particular.

A natureza de algumas secções conferem-lhe, também, feições de informação e entretenimento.

Compõe-se esta, colecção de 24 números. A sua estrutura é a mesma, quanto a formato e número de páginas. Internamente, a primeira página é, normalmente, dominada por um artigo de fundo, onde se abordam temas diversos. Seguem-se, depois, outros pequenos textos, de muito menor importância, bem como as seguintes secções: "Carteira», onde se fornecem as mais variadas e diversas notícias e informações; «Honni soit qui mal y pense», espaço para «coisas e loisas», não só de Portugal, mas também do Brasil. Numa crítica velada aos políticos e aos poderes instituídos, lê-se aqui: «Temos dois acontecimentos notáveis à porta. Sábado é Lua Nova e domingo temos nova Câmara Legislativa. Daquela esperamos a costumada luz para espancar as trevas da noite. Desta poderemos esperar que nos dê a luz que precisamos para seguirmos melhor caminho? Eis uma pergunta que não nos parece fácil de responder» (Idem, n. ${ }^{\circ}$ 8, p.p. 3-4, col. 2-1).

A par destas, outras, embora com vida mais curta, como: «Câmbios», "A Rir» e «Pensamentos». Desta última retiramos, a título de exemplo, o seguinte: «Aquela que tem um bom genro ganhou um filho; mas aquela que o tem mau perdeu uma filha» (Idem, n. ${ }^{\circ} 22$, p. 4, col. 2).

Os pequenos jornalistas de $A$ Pátria, nos artigos que escreveram, reflectiram, embora de maneira simples e rápida, sobre os seguintes temas e questões:

- Educação e Ensino: críticas aos governos de João Franco e José Luciano por não apostarem na instrução popular; referência ao livro D’onde provem a superioridade dos Anglo-Saxónicos de Edmond Demolins; a superioridade dos ingleses nestas matérias; exemplos de colégios e escolas inglesas: seus horários, métodos, objectivos e conteúdos de ensino. 
- História: pequenas alusões a figuras e factos da nossa história: António da Silveira, Matias de Albuquerque, José do Patrocínio, jornalista, que, no Brasil, lutou contra a escravatura, Gungunhana, a tomada de Santarém, a saída da frota de Vasco da Gama para a Índia, a revolta do 31 de Janeiro e relações Portugal-Brasil.

Pequenas referências também: à guerra entre a Turquia e a Grécia, a questão de Creta, religiões (egípcia, babilónica e cristã), necessidade de estudar literatura e antiguidades indianas.

- Política/Sociedade: críticas à acção do governo; a dissociação povo-governo; a perseguição movida ao Prof. Alves Moreira, pelo simples facto de «ser democrata e presidente da Comissão Municipal Republicana desta cidade» (Idem, n. ${ }^{\circ} 4$, p. 1, col. 1); a mania do emprego público: «Todo o cidadão português no pleno gozo de todos os seus direitos civis, e com atestado de que foi vacinado, e que venha declarar autenticamente que não é, e nem será nunca pretendente a emprego público, terá uma gratificação de réis $200 \$ 000$ por uma só veZ» (Idem, n. ${ }^{\circ} 11$, p. 1, col. 2); jogos clandestinos.

De âmbito local, em artigo de fundo, uma breve alusão ainda à inauguração do novo matadouro municipal e uma chamada de atenção para a necessidade de proceder a melhoramentos na praça do mercado.

Completa-se este jornal com poesias, pequenos textos literários em prosa e folhetins. 


\section{2 - O PENSAMENTO}

$\begin{array}{ll}\text { Folha Literária } & \text { Cotas: } \\ \text { Coimbra, Imprensa Comercial } & \text { BN: J.1432B.j.1639//1V. } \\ 12 \text { Maio } 1880 \text { - } 11 \text { Junho } 1880 & \text { BGUC: - } \\ & \text { BPMP: - } \\ & \text { BMC: GHC -20/10 }\end{array}$

Redactor: A. A. de Lima Duque

Colaboradores: J. A. Lopes Ferreira e Beatriz Alzira

R. C. Paiva

Formato: $22 \times 32,3 \mathrm{~cm}$

Periodicidade: Quinzenal

Preço: Trimestre - 240 réis

Páginas: 4

\section{Objectivo}

«É o mais simples possível o programa deste jornal. O Pensamento será literário: e neste título se apresenta.

Vivendo no século gigante, que percorremos, buscará, contudo, o ar menos viciado da nossa idade risonha: essa época de flores, em que o homem ainda sonhava e em que a lua tinha encantos.

A sua escola é aquela do poeta e do historiador, magno por excelência cujo nome imorredouro a literatura guarda no santuário dos maiores vultos - é a escola de Herculano.

O seu fim é levar o suave passatempo ao meio do oceano do tédio. Se sossobrar, resta-lhe ao menos a glória de ter desejado ser útil.

Eis o que promete e o que tentará cumprir» (n. ${ }^{\circ} 1$, p. 1).

«Como nós somos estudantes, e estão próximas as provas finais dos nossos estudos; como não podemos atender com a assiduidade necessária a duas coisas tão opostas - ciências positivas e trechos de lirismo - pedimos aos nossos ... assinantes, que nos perdoem a interrupção, por mês e meio, do nosso modesto jornal. Continuar-se-á a publicar, impreterivelmente, no dia 12 de Agosto do corrente ano»(Idem, n. ${ }^{\circ}$ 3, p. 4, col. 2). 


\section{Conteúdo}

Como se refere no subtítulo e nas palavras que lhe servem de apresentação, este pequeno e modesto periódico, fundado por um estudante do liceu, afirma-se como um jornal literário, cujos propósitos são ajudar a passar o tempo.

Nos três números que compõem esta colecção, a estrutura é a mesma, quando se tem em conta o formato e o número de páginas. Internamente, é de anotar a falta de artigo de fundo, a existência de uma secção permanente intitulada "Revista Bibliográfica», onde as obras publicadas e remetidas à redacção "serão avaliadas cuidadosamente, segundo o nosso critério» (n. ${ }^{\circ}$ 1, p. 1, col. 2), para a última página ser dedicada à publicidade, mas apenas nos dois primeiros números.

Como jornal literário, as suas colunas são dominadas por pequenos textos de carácter literário, em prosa e verso, ou, por «trechos de lirismo», nas palavras do seu responsável.

Completam este jornal um folhetim e um artigo de carácter filosófico intitulado «Amor e Sensualismo», onde se explanam as posições de Platão, Arístipo de Cirene e Epicuro sobre o assunto. 


\section{3 - O PEREGRINO}

Publicação Literária Cotas:

Coimbra, Imprensa da Universidade

$1871^{(1)}$

Director: António Bettencourt Rodrigues

Colaboradores: G. Redondo, Amélia Janny, Silva Ramos, Mariana Angélica de Andrade, António de Macedo, Luís Sarrea, A. B. Rodrigues, Guiomar Torresão, Magalhães Lima, Eugénio de Castilho, Agostinho Albano, Lourenço de Almeida, A. E. Macedo Ortigão, Alves de Morais, A. Sérgio de Castro, Júlio Garcia, Maria Rita Chiape Cadete, Júlio César Machado, Annes Baganha, Luís Carlos

Formato(s): $19 \times 27,5 \mathrm{~cm} \bullet 14 \times 22,2 \mathrm{~cm}$

Periodicidade: Não indica

Preço: Assinatura mês - \$130

Páginas: 8-12
BN: J.179//1B.;J.1417B.

BGUC: $10-5-21-12$

BPMP: -

BMC: GHC $-20 / 2$

\section{Objectivo}

«Ei-lo a correr o mundo da publicidade. A tarefa é árdua e o trilho difícil... Nas longas peregrinações a Meca, através as extensas planícies do Saará, as caravanas de peregrinos vêem-se, por mais de uma vez, atacadas por um inimigo terrível: a tempestade de areia...

Redobra o passo, anda léguas e léguas, através de um mar de areia, e o lago sempre a fugir-lhe e a vegetação a desaparecer-lhe. É a miragem.

O peregrino teme mais a miragem, que a tempestade de areia. Esta pode num momento sepultá-lo, terminando-lhe a fadiga; aquela ilude-o até ao momento em que, julgando-se apenas a alguns passos do lago vivificante, as forças lhe faltam e cai extenuado. Morre com a ilusão amarga e atormentadora de que ainda poderia viver...

(1) Não há referências a outros elementos temporais. 
No mundo literário podem também haver tempestades de areia, miragens e verdejantes oásis. As tempestades e miragens afastá-las-á o Peregrino com a força e vigor dos escritos de seus ilustres colaboradores. E o oásis??» (O Peregrino, $1^{\text {a }}$ Série, n. ${ }^{\circ}$ 1, p. 1).

\section{Conteúdo}

Trata-se, como o próprio subtítulo refere, de uma publicação de carácter literário.

Compõe-se esta pequena publicação de duas séries, ambas com a data de 1871. A primeira série é formada por seis números; da segunda saiu apenas o número um. Os dois primeiros números da 1 ${ }^{\text {a }}$ Série são ligeiramente diferentes de todos os outros, quer quanto ao formato, quer no que se refere ao número de páginas.

Para além de uma certa produção literária com poesias várias e textos em prosa como, por exemplo, «Horas de agonia», «Folha ao vento», «Devaneios» e «Cambiantes da comédia humana» é de salientar, no domínio da literatura, o estudo sobre Edgar Poe, da autoria de Magalhães Lima.

Com a assinatura de Lourenço de Almeida, um artigo intitulado «Sucessão dos sistemas filosóficos», onde se reflecte sobre a relação sociedade e filosofia. Aqui se faz uma exposição sucinta da filosofia da Índia, da China e da Pérsia e suas principais escolas, enquanto Alves de Morais teoriza sobre as origens, em «A Humanidade».

Completa-se este periódico com uma informação sobre as cheias do rio 252 Mondego, no ano de 1831. 
Formato: $16,5 \times 24,3 \mathrm{~cm}$

Periodicidade: Semanal

Preço: Não indica

Páginas: 4

\section{Objectivo}

«Desejando ser sempre agradáveis aos nossos leitores mimoseando-os com novidades resolvemos hoje apresentar-lhes no frontespício do Pimpolho um pepino e dois tomates cujo suco recomendamos aos nossos assinantes para limonadas refrigerantes.

Devemos porém prevenir os nossos leitores de que este suco é prejudicial... e pode às vezes produzir-lhes... de ventre» (n. ${ }^{\circ} 5$, p. 1).

\section{Conteúdo}

Segundo Carneiro da Silva (Ob. cit., p. 104), O Pimpolho é um pequeno jornal, semanário, copiografado, de alunos do ensino secundário, do qual se publicaram seis números, em datas não precisas.

Na B. M. C. existe apenas o n. ${ }^{\circ} 5$, que ostenta a data de 21 de Junho de 1895. É um exemplar de leitura difícil, em virtude da pouca clareza com que a letra se apresenta. Trata-se de um número sem interesse, onde se referenciam pequenas notas, um folhetim, charadas e logogrifos.

(1) Os elementos aqui referidos dizem respeito apenas ao n. ${ }^{\circ} 5$. 
95 - O PIRILAMPO (1)

24 Dezembro 1882

Cotas:

$\mathrm{BN}$ : -

BGUC: -

BPMP: -

BMC: -

(1) Tanto Carneiro da Silva (Ob cit., p. 104) como Fernando Pinto Loureiro (Ob. cit., p. 57, col. 1) nos dizem que com este nome se publicou o n. ${ }^{\circ} 1$ de um periódico de estudantes, em 24 de Dezembro de 1882, mas que não chegou a sair, por falta de pagamento à tipografia. 


\section{6 • O PIRILAMPO}

$\begin{array}{ll}\text { Hebdomadário científico e literário } & \text { Cotas: } \\ \text { Coimbra, Imprensa Académica } & \text { BN: - } \\ 8 \text { Março } 1888-12 \text { Maio } 1888 & \text { BGUC: - } \\ & \text { BPMP: - } \\ & \text { BMC: GHC -20/8 }\end{array}$

Director: Lomelino de Freitas

Colaboradores: Queirós Ribeiro, Machado de Almeida, Júlio Celeno, Berta de Castro, Eduardo Ruivo, Francisco Bastos, Júlio César Machado, Duarte de Vasconcelos, J. Marcelino, Eugénio Guedes, Octávio Guedes, Alberto Pimentel, J. Augusto Bernardes, Benjamim Jorge Gonçalves, Fernando Caldeira, A. F. Castilho, Joaquim de Araújo, J. Simões Dias, Clorinda de Macedo, J. Ferreira e João Gonçalves de Melo

Formato: $24,3 \times 33 \mathrm{~cm}$

Periodicidade: Semanal

Preço: Trimestre - 300 réis • Avulso - 30 réis

Páginas: 4

\section{Objectivo}

«Dando começo a este hebdomadário, não queremos nem devemos deixar de apresentar aos nossos assinantes o plano em que fundamentamos esta folha. São os seguintes: Primeiro - Sendo o carácter principal deste jornal a literatura -, o pensar dos fundadores desta folha, foi o de indicar aos olhos da literatura patriótica, homens de que o talento está como que sepultado sob a classe - ouvrière. Não pareça mal a nossa democracia aos leitores, porque, o que mais desejamos é a - instrução, chave que muitas vezes abre preciosos tesouros.

Segundo. - Sendo (como é) barata esta folha enquanto às matérias de que trata, o nosso desejo não só é o de espalhar a instrução nas baixas classes, mas também de misturar o útil com o agradável.

Abençoe Deus a missão a que nos propusemos, e queira ele que o facho da verdade nos alumie sempre.

Terminamos este prefácio, pedindo para a nossa folha a muita benevolência dos nossos assinantes» (n. ${ }^{\circ} 1$, p. 1, col. 1). 


\section{Conteúdo}

Conforme se refere nas palavras que lhe servem de prefácio, $O$ Pirilampo é um periódico literário e científico, que procura contribuir para a ilustração das classes menos favorecidas.

A colecção completa desta publicação compõe-se de dez números, todos com o mesmo formato e número de páginas.

No campo literário são de anotar produções traduzidas em textos em prosa como, por exemplo, «Marta», que é um conto da autoria de Machado de Almeida, «O Areial Traidor», extraído dos Miseráveis de Victor Hugo e «O Rés-do-Chão» de Paulo de Kock, entre outros, e muita poesia. Ao nível poético salientamos «Hecatombe», de Clorinda de Macedo, em homenagem às vítimas do sinistro que houve no Teatro Baquet, na noite de 21 de Março de 1888, na cidade do Porto.

Ao nível do romance histórico aponta-se, repartido por vários números, «Os Fidalgos do Coração de Ouro», de Manuel Pereira Lobato, que referencia o cerco feito por Abdalá e Mafamede à praça portuguesa de Mazagão.

No campo da biografia, dois estudos: um sobre a vida e obra do músico João Filipe Rameau e o outro sobre Francisco António Rodrigues de Gusmão.

A divulgação, também, de uma cultura de carácter mais utilitário e prático, com conhecimentos úteis para a vida. É neste sentido que devem ser entendidos os textos «O tabaco» e «A cultura da batata». Neste, por exemplo, dão-se instruções, não só como deve ser cortado o tubérculo para semear, mas também a importância de cuidados a observar.

Um conjunto de referências e notas que têm a ver com os títulos dos próprios textos. Em «Chicago», dão-se informações e notícias curiosas sobre a cidade americana com aquele nome; em «Costumes ingleses», fala-se de certos hábitos, entre os britânicos, que se observam na semana santa; em «Victor Hugo e a pena de morte», descreve-se uma cena de tortura, numa praça de Paris. A este propósito escreve-se: «afastei-me dali firmemente resolvido - tinha então 16 anos - a combater sempre as más acções da lei. Destas más acções a pena de morte é a pior» (n. ${ }^{\circ} 6$, p. 1, col. 1). 
Completa-se este periódico com as seguintes secções: «Carteira do Globo», onde se dão notícias várias do mundo; «Crónica», espaço para pequenas notícias de carácter local e nacional e «Miscelânea» com charadas e anedotas. Na última página a existência de publicidade. 


\section{7 - A PORTA FÉRREA}

Jornal Académico de Coimbra

Coimbra, Imprensa Comercial

13 Novembro 1881 - 1 Maio 1882
Cotas:

BN: J. 3591//131M.

BGUC: -

BPMP: -

BMC: -

Redactores: Trindade Coelho (Belisário), Solano de Abreu (Salamandra), Santos Melo (Gualberto) e Eduardo Vale (Quizomba) e Artur Ribeiro

Colaboradores: E. Costa Macedo

Formato: 25 x $35,5 \mathrm{~cm}$

Periodicidade: Semanal

Preço: Trimestre - 400 réis

Páginas: 4

\section{Objectivo}

«Não tremam as instituições... Não quer isto dizer que dez arrobas de monarquia ou um século de república nos sejam perfeitamente indiferentes ou que procuremos nesta publicação apenas um calmante à sensaboria que tenta por vezes matar-nos, como procuraríamos um Rigollot para uma constipação que nos incomodasse.

Em matéria de filosofia não somos bem ecléticos, mesmo porque o ecletismo é um sistema filosófico que implica até certo ponto uma oscilação de espírito que nem é conveniente nem racional. É bom que tenhamos convicções solidamente baseadas em dados apurados pela ciência. Não hostilizaremos ninguém na santidade de suas opiniões. Paulo Janet e Augusto Comte não consta que se 258 insultassem...

Não nos correspondemos com o centro nihilista russo, nem com os socialistas alemães. Acatamos a Carta e entusiasma-nos o hino da independência. Gostamos da Marselheza e o hino do papa derrama-nos na alma uns vagos tons untuosos de uma liturgia beata.

Tanto estendemos a mão ao Sr. Fontes, como nos desgorramos diante do Sr. Braamcamp ou destraçamos a capa na presença do Sr. Dias Ferreira.

A Porta Férrea é um jornal de estudantes, é um jornal literário, antes de mais nada. 
Que defendamos os nossos interesses, o interesse da classe, c'est l'esprit d'école, ninguém o pode levar a mal.

E neste pressuposto, se tivermos de fazer crítica, havemos de ser sinceros, sem espírito de partido ou facciosismo.

Queremos estar de bem com todos e cooperar, quanto em nossas forças caiba, para o bem daquela que nos amamentou em seus seios - a pátria...

Está feito o programa» (n. ${ }^{\circ} 1,13$ de Novembro de 1881, p. 1, cols. 1 e 2).

\section{Conteúdo}

Trata-se, conforme salientam os seus responsáveis, de um jornal fundamentalmente literário e, como tal, apostado em ilustrar e instruir. Nele se faz, também, uma defesa dos interesses da Academia.

É Trindade Coelho quem, em In Illo Tempore (pp. 78-79), nos conta a história deste periódico. A colecção completa é de vinte e três números. Trindade Coelho, no relato que nos faz, fala-nos em mais um número, «com gravura e papel amarelo - obra de luxo! - dedicado ao centenário de Pombal!» (p. 79). Este número que ele apelida de «número de gala» (Idem), não chegou a sair, porque não foram pagos, adiantadamente, ao editor, «o feroz José Correia» (Ibidem), a quantia de 5000 réis.

Infelizmente, nas bibliotecas de Coimbra não há nenhum exemplar deste jornal. Também na Biblioteca Nacional, a colecção é extremamente deficitária. Recordando Trindade Coelho e numa breve alusão ao jornal A Porta Férrea, Viale Moutinho diz-nos que a "colecção completa não se consegue encontrar» (Diário de Notícias, Ano 138, n. ${ }^{\circ} 48621,7$ de Maio de 2002, p. 7). Aliás, este mesmo repórter faz, inclusivamente, um apelo a «alguém que a tenha e me deixe dar-lhe uma vista de olhos» (Idem).

Nos dois números por nós consultados ( ${ }^{\text {os }} 1$ e 7), a estrutura é sensivelmente a mesma. Para além do formato e do número de páginas ser o mesmo, a primeira página é dominada por um pequeno artigo de fundo a que, depois, se seguem artigos e rubricas várias. Se o artigo de fundo, no primeiro número, com o título de «Quem somos e o que queremos», diz respeito à apresentação e propósitos do jornal, já, em o n. ${ }^{\circ} 7$, é dedicado aos estudantes do Porto, para evidenciar o sentido de solidariedade e gratidão que aquela academia teve para com um colega de Coimbra, «desprotegido da fortuna» (n. ${ }^{\circ} 7$, p. 1, col. 1). 
Em ambos os números, a existência da secção «Rendilhados», onde se inscrevem textos em prosa como, por exemplo, «Por causa d'uma boquilha (Enguiços Feminis)»e «Guilherme». O mesmo com a secção de «Expediente», onde se dão notícias do jornal. Por aqui ficamos a saber que, a partir do n. ${ }^{\circ} 7$, houve alterações na estrutura interna do periódico, uma vez que "por falta de espaço retiramos completamente a secção «Reporter», como também retirámos as «Quisombadas». (N. 7 , p. 4, col. 3). Advertem-se os leitores que nada perderão com isto, porque «no próximo número terão indemnização completa do detrimento que porventura lhes causemos» (Idem).

Para além de alguma poesia, pouca, dominam nestes periódicos reflexões sobre temáticas como:

- Imprensa. No artigo «O jornalismo actual na sua maioria», Trindade Coelho reflecte sobre a missão que cabe à imprensa. Aqui se criticam as publicações que se deixam adular por partidos políticos ou que se subjugam a determinados interesses. Defende-se que "a missão do jornalismo é nobre e grandiosa» (n. ${ }^{\circ}$ 1, p. 1, col. 2), e, portanto, deve preocupar-se com o Direito, a Verdade e a Justiça.

- Política/Sociedade. Simpatizante das ideias da Revolução Francesa, Santos Melo, em «Duas Palavras», reconhece o atraso em que Portugal se encontra.

As lutas mesquinhas em que os nossos políticos se envolvem, o nosso temperamento, o nosso atraso cultural e o jesuitismo são os responsáveis mais directos pela situação. Impõe-se, por isso, uma regeneração social e esta missão pertence «aos democratas que devem representar neste combate titânico os obreiros do progresso...» (n. ${ }^{\circ} 1$, p. 2 , col. 1).

Embora se reconheça que, em Portugal, em termos políticos, tem havido algum progresso, na prática não se têm colhido grandes frutos. Uma das causas tem sido o comportamento de alguns republicanos. Daí as críticas que Solano 260 de Abreu, no artigo «Gomes Leal», faz ao autor de Traição, na perspectiva do político, do cidadão e do poeta.

Soluções para o desenvolvimento material e social passam pelo estudo e pelo trabalho. Só estudando e trabalhando é possível «instruir o povo, satisfazendo assim uma obrigação imposta a todos nós, se quisermos cumprir os deveres que assistem a todos os bons cidadãos» (n. ${ }^{\circ} 7$, p. 2, col. 2). É este o sentido do artigo «O nosso dever».

Em termos políticos, as simpatias estendem-se, também, à Irlanda e ao seu povo, onde a Liga Agrária e o seu presidente Parnell são vítimas de repressões 
por lutarem contra os opressores e os exploradores, como se lê no artigo com o título «A Irlanda opressa».

- Academia. Referem-se incidentes da academia com a polícia; críticas a António Arroio e a uma pretensa Federação Académica Peninsular.

Para além dos habituais folhetins, completam este periódico algumas notícias sobre o teatro em Coimbra, nomeadamente, a presença da Companhia de Emília Adelaide, no teatro Académico, e da representação, no teatro Conimbricense, do drama Sargento Mor de Vilar. Ainda relativamente ao teatro Conimbricense, publica-se uma carta do seu proprietário, José Correia de Almeida Júnior, a propósito de um incidente com estudantes, naquela casa de espectáculo.

Bibliografia: Trindade Coelho, In Illo Tempore, Publicações Europa-América, n. ${ }^{\circ}$ 287, Mem Martins, s.d., p.p. 78-79; Viale Moutinho, «Com Trindade Coelho», Diário de Notícias, Ano 138, n. ${ }^{\circ} 48621,7$ de Maio de 2002, p. 7. 
$98 \cdot$ PORTUGAL $\left(1 .^{\circ}\right)$

Orgão dos Estudantes Republicanos

Coimbra, Tip. Minerva Central

14 Abril 1896 - 7 Julho 1896

Editor: J. M. S. Nazaré,

Redactores: Artur Leitão, Alexandre Braga, Guedes

Teixeira, Joaquim Madureira e Pais Gomes

Colaboradores: Augusto Gil, Pedro Martins, António

Silveira, Gonçalves Cerejeira, João Tudela, Manuel

Joaquim Massa, Carlos de Lemos, Joaquim Martins

Carvalho

Formato: 34 x $50 \mathrm{~cm}$

Periodicidade: Semanal

Preço: Avulso - 10 réis $\bullet$ Assinatura - Ano - 600 réis

Páginas: 4
Cotas:

BN: -

BGUC: O.S. 1045

BPMP: -

BMC: GHC $-21 / 5$

\section{Objectivo}

"Aparece um jornal: - a velha hipocrisia portuguesa atira-lhe às colunas um artigo programa, pretexto apenas para uma doirada mentira. Intransigência, moralidade, desinteresse, amor de pátria, defesa dos humildes, todo um desdobrar de altivos sentimentos apregoados, vêm à flor do tipo de impressão, erguer a voz de mais uma consciência que se diz revoltada. Peneirada a retórica saloia, descortina-se detrás do papel um grupo de malandros agachados na maroteira: - são os que vão às câmaras, os que vestem a libré de ministros, os que nos roubam, nos desonram, e, para certeza de impunidade, nos fazem calar, prendendo-nos.

E a onda cresce sempre...

É olhar em volta essa nauseante coisa que se chama o jornalismo português: - turba de quadrilheiros, fugidos por cobardia das estradas onde se joga a vida, atacam-nos assim, dentro da lei e em nome dela, a bolsa e a liberdade.

Não se chamam ladrões; dizem-se a opinião pública...

Não faremos como eles.

Inútil é justificar com programas a missão que somos chamados a cumprir na vida nacional; pelo que fizermos, não pelo que prometermos, havemos de ser julgados. 
Pela Pátria queremos a República, pela República a revolução. Nada mais claro, nada mais definido, nada mais simples...» (Portugal, n. ${ }^{\circ}$ 1, Coimbra, 14 de Abril de 1896, p. 1, col. 1).

\section{Conteúdo}

É importante que se recorde, antes de mais, que, após a revolta do 31 de Janeiro de 1891, se criou um clima de desconfiança entre os republicanos com ameaças e acusações mútuas, na medida em que a Direcção do partido, de tendência moderada, não apoiou os revoltosos. Ao defenderem a revolução como o melhor meio para a implantação da República, estes estudantes estavam assim a assumir uma linha mais radical.

Organizado por um conjunto de estudantes republicanos, este jornal pretende não só denunciar a política dos diferentes governos monárquicos, mas também criticar a maneira como a direcção do partido republicano se tem comportado e empenhado na luta pela consagração da República.

Ao longo dos seus dez números, a estrutura interna deste periódico é muito semelhante. Uma boa parte da primeira página é dedicada ao artigo de fundo, seguindo-se-lhe um conjunto de textos e rubricas várias, com a última página reservada à publicidade.

Num inventário temático seria possível identificar o tratamento das seguintes questões:

- A política monárquica: erros, vícios e atropelos;

- A enorme dependência do rei e do governo em relação à Inglaterra;

- Propostas programáticas de uma nova república.

Podemos identificar ainda alguns textos de natureza doutrinária como por exemplo: «Os missionários» e «O veto» de Manuel Joaquim Massa; «Teoria Histórica Socialista» de Manuel da Silva Mendes.

Completam este jornal um conjunto muito variado de pequenas notícias, poesia, publicações recebidas e um folhetim - A Desafronta de António José de Almeida. 


\title{
$99 \bullet$ PORTUGAL $\left(2 .^{\circ}\right)$
}

\author{
Semanário Republicano Académico Cotas: \\ Coimbra, Tip. Operária BN:- \\ BPMP: - \\ BMC: GHC $-21 / 3$
}

Editor: José Maria dos Santos Nazaré

Colaboradores: Lopes Guimarães, Carlos Antunes

Formato: 31 x $44 \mathrm{~cm}$

Periodicidade: Semanal

Preço: Trimestre -350 réis

Páginas: 4

\section{Objectivo}

«Neste termo (Portugal) se consubstancializa a ideia nobre e santa que nos inspira em frémitos de terno amor: amar a Pátria é contemplar a Humanidade, e hoje ser patriota é ser republicano.

Pátria e República são hoje duas ideias complementares sem uma das quais a outra não pode ser...

«Pregamos, como passo para a felicidade futura, a República federativa», dizia um manifesto socialista publicado nesta cidade e redigido por um dos redactores deste semanário; Gonçalves Cerejeira, o novo bacharel ilustrado e o republicano pur sang, proclama também a federação para a realização plena da sociabilidade humana, que, pelo gradual e progressivo desenvolvimento das normas de fraternidade emanadas do instinto ou sentimento altruísta, vem, pois, completar o homem individual, integrando-o na construção harmónica dos diversos orgãos; nós, pelo nosso lado, ansiamos pela sua realização, tanto mais que «a organização federal dos Estados livres da Península Ibérica impõe-se irresistivelmente a todos os espíritos sensatos como uma conquista do progresso e uma garantia da nossa liberdade autonómica».

O Grupo Republicano de Estudos Sociais, que temos a honra de cumprimentar... advoga iguais ideias e o federalismo é também o ideal supremo do nosso prestimoso mestre, o Sr. Dr. Teófilo Braga...

Republicanos dentro da monarquia, seremos federalistas dentro da República, pugnando ainda por a mais lata extensão da sociabilização humana na ideia e na prática. 
Não traçamos um programa, esboçamos o nosso modo de sentir e pensar», (Portugal, n. ${ }^{\circ}$ 1, Coimbra, 7 de Novembro de 1897, p. 1).

\section{Conteúdo}

Deste periódico saíram apenas três números. Em 2 de Dezembro de 1897 saiu mais um número, mas com o título de Clarim das Ruas..

Portugal é um pequeno jornal republicano que, para além de um pequeno editorial, na primeira página, contém um conjunto de textos e rubricas várias, que podemos sintetizar nas seguintes questões:

- Administração do regime monárquico: problemática do jogo, comportamento das forças policiais e seus comissários, inadequação da legislação eleitoral de 1895 e 1896, a quem chamam de «retrocesso político» (p. 2), retrato de Portugal.

- Defesa da República e da Revolução. Se a República é «o anjo salvador» (p. 3), a revolução é a «única solução (que) se nos impõe como verdadeira e necessária nas condições actuais e desgraçadas do país» (n. ${ }^{\circ}$ 2, p. 3).

- Críticas e resposta a um estudante republicano, Alexandre Matos, por ter colaborado num jornal adverso, o Correio da Noite, descompondo alguns republicanos. Daí a crítica irónica do título, várias vezes repetido, «Apostatou?».

Notícias várias e diversas. 


\section{$100 \bullet \mathrm{O}$ POVO}

Jornal Bimensal dedicado às classes operárias

Coimbra, Tip. Santos e Silva

1 Julho 1866 - 31 Outubro 1866
Cotas:

BN: J.327//8P.;

BGUC: J.1393 B.

BPMP: -

BMC: GHC $-20 / 5$

Directores: Joaquim Vale e Faustino Sarmento

Colaboradores: António Maria Seabra de

Albuquerque, José Simões Dias, Manuel de

Assunção, M. Emídio Garcia, Francisco Guimarães

Fonseca, Eugénio de Barros, João Penha, R. Pinto,

Luís Jardim, José de Sousa Monteiro Júnior, Álvaro

do Carvalhal, António José Teixeira e Luís Carlos

Simões Ferreira

Formato: 16 x $25,9 \mathrm{~cm}$

Periodicidade: Bimensal

Preço: Trimestre - $\$ 800 / 600^{(1)} \bullet$ Avulso - $\$ 120$

Páginas: 72

\section{Objectivo}

«Esplende a inteligência nas pugnas gloriosas da civilização; e os obreiros do pensamento, eternos defensores da Ideia, lutando sempre, e sempre conquistadores, antepõem a luz que consola à treva que entristece, o saber que exalta à ignorância que humilha, a lógica que convence à espada que mata.

Abençoado pois todo aquele que esclarece uma dúvida, expõe uma verdade, firma uma crença, e que inoculando a instrução na massa do povo, lhe infiltra com ela a moralidade e a virtude. Militando à sombra da bandeira que tem por mote-progresso e liberdade - este jornal alista-se nas fileiras daqueles que trabalham na santa cruzada da civilização popular. O Povo não formula programa; empenhar-se-á, sim, em que a luz da verdade irradie em todas as classes da sociedade». (n. ${ }^{\circ}$, p. 1 , col. 1 )

(1) «Outra advertência que a redacção tem de fazer diz respeito à diminuição do preço: um jornal dedicado às classes operárias não deve elevar a assinatura a tão alto que não possa ser possuído pela classe a favor de quem trabalha; por isso entende que, fixando em 600 réis a assinatura trimestre concilia a despeza do jornal com os interesses dos assinantes» (n. ${ }^{\circ}$ 2, 15 de Julho de 1866, p. 13, col. 1). 


\section{Conteúdo}

Trata-se de um pequeno periódico cujo objectivo principal é contribuir para a educação e instrução, sobretudo das classes operárias.

A colecção completa desta publicação é de seis números, todos com o mesmo formato e número de páginas.

Independentemente de outras rubricas, uma grande questão domina neste periódico. É a defesa que se faz de um projecto que visa criar uma Associação Cooperativa de Artistas. É R. Pinto quem, numa tradução de um artigo de Charles Lavollée, se debruça sobre o assunto, num texto intitulado «Estudos sobre economia social» e que J. Vale complementa, quando nos fala da Associação dos Artistas de Coimbra.

Reflectindo sobre o poder do capital, o papel dos «mestres», questões de dependência e reconhecendo-se que as lutas de classe não se justificam, porque «as desigualdades são naturais» (n. ${ }^{\circ} 3$, p. 25, col. 1), opina-se que a criação de uma associação só tinha vantagens, na medida em que «não recrutaria senão iguais, vingaria a dignidade humana ao mesmo tempo que derramaria o bem-estar e a fortuna no vasto campo do trabalho» (n. ${ }^{\circ}$ 1, p. 7, col. 1). Para além de benefícios económicos e salariais, há que ter também em conta outros valores. Citando o exemplo da Associação dos Artistas de Coimbra, de que El-Rei D. Fernando é protector, o trabalhador, alí, « trabalha e civiliza-se. Ama a Deus, e é virtuoso» (n. ${ }^{\circ} 3$, p. 25, col. 2).

Outra questão é a que se prende com o propósito que Manuel Emídio Garcia tinha em abordar, numa série de artigos, o casamento civil. Publicaram-se apenas três, com o título de «Surge et Ambula! Ao Povo». Reflectindo sobre os diversos contributos de que a nossa jurisprudência é depositária, evidenciando o marco que foi a Revolução Francesa, louvando as novas conquistas e os novos saberes, Emídio Garcia não deixa, contudo, de criticar a acção dos sectários do ultramontismo, uma vez que «continua a activar o espírito de superstição nas massas, que querem ignorantes e inertes» (n. ${ }^{\circ} 1$, p. 6 , col. 1).

Aludindo, também, às revoluções inglesa e francesa, meditando sobre a filosofia iluminista e o tempo do Marquês de Pombal, ponderando das razões que levam as nações a fazer revoluções liberais, faz uma análise às causas da revolução liberal portuguesa. 
Num juízo de valor sobre este estudo, O Povo diz-nos que há nele «pensamentos elevados e grandes ideias: a crítica com que está descrita a época do Marquês de Pombal, a análise da revolução liberal de 1820, e de muitos outros factos históricos coloca este estudo a par das melhores produções a que se tem dado o nome de filosofia da história» (n. ${ }^{\circ} 1$, p. 1, col. 1).

Nos domínios da história e da filosofia, salientam-se, para além de cartas de José Monteiro da Rocha para D. Francisco de Lemos, sobre assuntos literários e políticos, o estudo de António Maria Seabra de Albuquerque intitulado «Os Bastardos. A coroa real portuguesa», o trabalho de José de Sousa Monteiro Júnior, «Respha», onde se cantam as mulheres da Bíblia e «Fragmento histórico", para, invocando o sentido histórico, se discorrer sobre o caminhar e evoluir da civilização; Luís Jardim, em «Cartas a um filósofo», fala-nos, não só de filósofos vários, mas também da influência da Igreja Católica na civilização.

No campo literário, poesias várias e o conto «Everardo», de Álvaro do Carvalhal.

Completa-se este periódico com a secção permanente de «Crónica», onde o seu autor nos narra acontecimentos e nos dá notícias de Coimbra e de outras paragens, porque «chegou... a época em que a crónica nesta boa terra (Coimbra) é dificílima, senão impossível» (n. ${ }^{\circ}$ 3, p. 36, col. 2). 


\section{1 • A PRAÇA PÚBLICA}

Coimbra, Tipografia Operária

Abril 1897

Director: Artur Leitão

Colaboradores: António José de Almeida, Joaquim Madureira, F. Macedo Pinto

Formato: 13 x $19 \mathrm{~cm}$

Periodicidade: Não indica

Preço: 50 réis

Páginas: 32
Cotas:

BN: L. 23169//10 P;

L. $23170 / / 3 \mathrm{P}$;

L. $33172 / / 3$ P.;

J. $974 / / 14$ P.

BGUC: -

BPMP: -

BMC: GHC -4

\section{Objectivo}

«Somos um grupo de insubmissos e rebeldes, irmãos gémeos dos poucos homens que neste desacreditado país - onde um Navarro é um estadista e um estadista um Navarro - pensam pelo cérebro e não pelo estômago...

É esta tropa desavergonhadíssima que escora o trono e dá realce à monarquia...

Vimos discuti-los, combatê-los, insultá-los. O ataque será rude e vigoroso, mas leal e franco. A peito descoberto sem clemências, mas sem traições, e quer brandindo uma espada, quer empunhando um cacete, instigaremos contra esta canalha a turba-multa dos oprimidos.

E as nossas cargas serão tanto mais violentas, quanto é certo que da monarquia nada precisamos e da futura República nada pretendemos.

Estamos no partido republicano como um viajante numa estação de caminho-de-ferro: com a mala pronta para marchar ao primeiro sinal.

Dispostos a dar à República o vigor da nossa idade e o calor das nossas convicções...

Eis ao que vimos.

Atiçar contra os burgueses a hoste incomensurável dos deserdados, mostrando-lhes os direitos que lhes sequestram e as injúrias de que são vítimas por parte dos senhores jornaleiros do crime, a tanto por cabeça.

É na praça pública, o campo santo das reivindicações, que gritaremos, alto e sem cerimónias, que a propriedade é um roubo, a remuneração do trabalho aos proletários uma falcatrua, a actual organização da família um ludíbrio... 
Além do combate à realeza, é preciso atear, contra os cavalheiros, o fogo em cujas labaredas há-de ser devorado o capital que adoram.

Oprimidos - a insurreição é um direito» (A Praça Pública, Coimbra, 1897, pp. 3-6).

\section{Conteúdo}

A Praça Pública é um pequeno periódico organizado por estudantes republicanos, alguns dos quais haviam já sido responsáveis por um outro periódico, em 1896, Portugal, mas que as autoridades encerraram.

Em A Praça Pública declara-se não só um combate à realeza, mas também uma denúncia das estreitezas e contradições dos governos monárquicos e seus aliados.

Em artigo intitulado «Dois reis», Joaquim Madureira compara as atitudes do rei Jorge da Grécia com as de D. Carlos de Portugal, para concluir que enquanto aquele foi «até onde a honra manda que uma nacionalidade vá», D. Carlos «curva-se ao ultimatum e, empenhado em viver em paz com o inimigo, conduz o povo, sob uma escolta de municipais, às forças caudinas de $20 \mathrm{de}$ Agosto» (p. 27).

Criticam-se os partidos políticos (Regeneradores e Progressistas), porque, quando na oposição, reclamam «moralidade, economia, liberdade, etc. No governo - Niassa, Juíz Veiga, Soveral, querelas, impostos, crimes e desonras» (p. 16).

Críticas igualmente para o clero, que «é trope... é devasso... é mau... é essencialmente estúpido e ignorante» (p. 29), especialmente um sacerdote que prestava serviço na Sé Velha de Coimbra, porque «insolente e desonesto», (p. 22) e ainda aos tempos litúrgicos, nomeadamente o período da Quaresma,

270 que, no entender destes jovens jornalistas, não passa de um tempo de «entrudo das igrejas» (p. 31).

Completa-se este periódico com um artigo de António José de Almeida intitulado «De África», o qual era para ser publicado em Portugal, mas como este periódico havia já sido extinto, foi agora dado à estampa. Recordando um pouco os seus tempos de Coimbra, António José de Almeida saúda e estimula os estudantes republicanos a continuarem a divulgar a mensagem da República, porque «a mocidade é sempre o precursor guerrilheiro da turba revoltada» (p. 9). 


\section{2・PREITO ACADÉMICO}

Congratulação dos filhos de Minerva pelo faustoso

66 aniversário natalício do Grão Varão

Joaquim Martins de Carvalho

Coimbra, [sl]

19 Novembro 1888

Colaboradores: João Duarte, Freitas Ribeiro, Oliveira Mourão, Eduardo de Magalhães, Mário da Silva, Caldas Quadros, Ferreira dos Santos, Manuel da Costa, Lúcio Pais, Mário Chagas, Gomes de Miranda, Artur de Macedo, António de Almeida, Oliveira Matos, Pinto da Rocha, Azevedo Campos, Ernesto de Vasconcelos, Francisco da Cunha, Francisco do Vale, Simão da Costa Pessoa, Artur Montenegro, Carneiro de Moura, Macedo de Melo, Pedro Gorjão, Carlos de Oliveira, Aníbal de Vasconcelos, Aníbal de Mendonça, Alberto de Oliveira, João de Menezes, Luís Melo Borges, José Pinto Leite, Costa Júnior, Agostinho de Campos, Ventura da Câmara, Francisco Couceiro, A.

Belchior de Macedo e Francisco Bastos.

Formato: $29 \mathrm{x} 42,3 \mathrm{~cm}$

Periodicidade: N. ${ }^{\circ}$ único

Preço: Não indica

Páginas: 4
Cotas:

BN:J. 734//42 A.;J. 775//48 A.

BGUC: 10 - 1- 24 - 1

BPMP: -

BMC: GHC -21/4

\section{Objectivo}

Não indica.

\section{Conteúdo}

Trata-se de um periódico de homenagem que a Academia de Coimbra fez a Joaquim Martins de Carvalho, na passagem do 66. Aniversário do seu nascimento.

Estes periódicos de homenagem são, normalmente, números únicos e nele colaboram vários estudantes e até outras personalidades. De uma maneira ge- 
ral, os homenageados são retratados em aspectos vários da sua vida. $\mathrm{O}$ profissionalismo e a hombridade de Martins de Carvalho são evidenciados, entre outros, neste pensamento assinado por Simão da Costa Pessoa: «Martins de Carvalho é o jornalista colossal, único... Martins de Carvalho é tudo. Todos os homens deviam chamar-se Martins de Carvalho» (p. 3, cols 1 e 2).

Em poesia, a agudeza de espírito do homenageado é ilustrada assim:

«O tal Fino é muito fino

O tal Fino é mesmo um alho,

Mas mais fino que o tal Fino

Só o Martins de Carvalho» (p. 4, col. 3) 


\section{3 • PRELÚdIOS LITERÁRIOS}

Coimbra, Imprensa da Universidade

Dezembro 1858 - Janeiro 1861

Redactor: Vicente da Silveira

Colaboradores: Emídio Garcia, Jaime C. Moniz, J. Alves Mateus, A. M. Cunha Belém, Firmino de Magalhães, Severino de Azevedo, Amélia Janny, A. Filipe Simões, Silva Gaio, A. M. Seabra de Albuquerque, A. L. Santos Valente, Eduardo Coelho, A. L. Simões de Carvalho, A. F. da Fonseca, Antero de Quental, José Augusto Teixeira Botelho, Joaquim Augusto Rodrigues, João de Deus, Sanches da Gama, J. Simões Ferreira, A. A. da Fonseca Pinto, Eugénio de Barros, F. Beirão, Francisco Brandão, António Francisco Barata, Elvira Cândida G. de Morais

Formato: $18,5 \times 27,5 \mathrm{~cm}$

Preço: Trimestre -360 réis $\bullet$ Avulso - 40 réis

Periodicidade: Quinzenal

Páginas: $1 .^{\circ}$ Vol. $-292 \bullet 2 .{ }^{\circ}$ Vol. -184

\section{Cotas:}

BN: J. 137B.; J.327//10P; J.841//2B.;J.966//27P J.1469B.

BGUC: $10-7-19-6$

BPMP: P/B/2694

BMC: GHC - $21 / 4$

\section{Objectivo}

«Tal foi o título, que escolhemos para uma publicação, que, de 15 em 15 dias, nos propomos fazer em Coimbra, - título modesto, como as nossas aspirações, e que, melhor do que nenhum outro, nos parece pôr em relevo a índole da mesma publicação.

Atravessando rapidamente o vasto campo da literatura e das ciências; estudando de passagem o coração do homem e a natureza... os redactores dos Prelúdios Literários não podem ter principalmente em vista senão a humilde pretensão de encontrar no futuro, quando a ciência, deixem-nos assim dizer, houver selado a sua carreira académica; quando a vida pública, materializandolhes as ideias, tiver tornado mais pesada a sua existência - algumas páginas, que, desprendidas da sua mocidade, e cheias de prazer ou de melancolia, de crenças sentidas no raiar da vida, lhes alentem os ânimos em árduas fadigas, lhes aumentem a coragem e aviventem a fé no porvir, que as decepções enlutam. 
Quem há, que, ao passar dos quarenta anos, não tenha experimentado prazer e saudade - ao ouvir repetir os seus contos de infância? Quem há, que, ao declinar da vida, não tenha sentido rejuvenescer-lhe a alma... ao recordar-se dos seus feitos passados, em que apenas entra a reflexão? Quem há, finalmente, que não tenha ao menos sacrificado à reminiscência duma existência inocente e livre o materialismo do cálculo da vida actual?... Estas e outras reflexões, que fizemos, não podiam deixar a seu tempo, de levar-nos a empreender a publicação de um jornal da natureza daquele, que anunciamos.

Dirigidas, coordenadas em deliciosa harmonia pelos mais hábeis; tenho por modelo e guia os escritos de alguns literatos de vulto, cujos nomes oportunamente publicaremos - as primeiras impressões, e, por ventura, as mais puras, as mais lisonjeiras de um grande número de académicos, nossos contemporâneos, vão ocupar no nosso jornal um dos melhores lugares e falar dá, umas vezes com melancolia, outras com entusiasmo, a linguagem viva e insinuante do sentimento - não só ao passado..., mas ao presente, que desponta, risonho, esperançoso e ardente...

Os outros lugares do nosso jornal serão destinados a algumas publicações científicas de fácil compreensão, e dum estilo próprio a conciliar o trabalho com o desejo de saber.

Finalmente, ensaiaremos várias traduções das obras mais recomendáveis de alguns literatos espanhóis, tão pouco conhecidos ainda dos nossos portugueses...

Mas, se por desgraça nossa, nos houvermos enganado: se o que prometemos tiver a infelicidade de não satisfazer as exigências daqueles, para quem escrevemos - fique-nos ao menos a certeza de que o preço da sua assinatura nunca será regateado ao dizer-se que - os lucros materiais desta publicação, se os houver, serão destinados a proteger, na sua carreira científica, o seu principal redactor» (n. ${ }^{\circ} 1$, p.p. 1-2).

«... desejosos de popularizar, quanto possível, os nossos escritos, como meio

274 não só de promover a instrução, mas de despertar em muitos um sentimento, que não deve dormir no coração de um bom português» (Idem, n. ${ }^{\circ}$ 6, p. 61, col. 1).

\section{Conteúdo}

Como o próprio título sugere, Prelúdios Literários é uma publicação de carácter essencialmente literário, cujo propósito fundamental é, como dizem 
os seus responsáveis, «educar agradando» (n. o 20, p. 229, col. 1). Daí, também, a existência de outras dimensões culturais, para além de algumas curiosidades interessantes.

A colecção completa deste periódico engloba 2 volumes, ambos com o mesmo formato. O primeiro é constituído por 24 números, num total de 292 páginas; o segundo com 23 números e 184 páginas. De salientar as produções musicais anexas aos $\mathrm{n}^{\circ \mathrm{s}} .5$ e 14 , do vol. $1 .^{\circ}$, respectivamente, «Polka para piano", por Elvira Cândida Garcia de Morais e «A Saudade. Valsa para piano forte», de Francisco José Brandão.

A dimensão literária deste periódico está presente em poesias várias e textos em prosa como, por exemplo, «Uma tarde de Abril», de A. M. Cunha Belém, «Vício e Virtude», um conto de Jaime C. Moniz, «A manhã na minha terra», de Eduardo Coelho, «Coisas e Loisas», um romance de J. Simões Ferreira e «Impressões de Viagem», onde se descrevem localidades e paisagens, entre outros.

Ao nível da poesia, para além da muita criação poética, é de salientar a apreciação que, em artigo com o mesmo nome, é feita à obra Lágrimas e Flores de J. Pinto Ribeiro.

Para além desta criação literária, a existência, também, de traduções como a que, por exemplo, Vicente da Silveira fez do romance «O Nobre e o Mendigo», de Vilchez, a que se pode juntar a extraída da língua espanhola com o título «O dia 23 de Junho», oferecida ao Dr. Manuel Carrilho Garcia.

No âmbito da literatura, os trabalhos sobre literatura alemã e espanhola, nos artigos intitulados «Estudo sobre as poesias de Schiller», da autoria de J. Alves Mateus e «Estudo. D. José Zorrilla», respectivamente.

Relativamente à literatura portuguesa é de referir o estudo intitulado "A terceira edição dos Lusíadas», a propósito das expurgações levadas a cabo pelos jesuítas à obra de Camões.

No âmbito de uma literatura epistolar e com o título «Epistolografia» escreve-se sobre um conjunto de assuntos como: o direito e o suicídio, a vida que se vive nas praias, o carácter das gentes de Cernache do Bonjardim e as festas de Natal e Ano Novo.

Na dimensão literária ainda é de salientar a defesa que Emídio Garcia faz do estudo e importância da língua latina, no artigo «Instrucção», onde escreve: «Todos aqueles que têm a ambição de se elevar no mundo científico, nas nações democráticas, devem alimentar o seu espírito nas obras da antiguidade» (n. ${ }^{\circ}$ 12, p. 136, col. 2). 
Outra das dimensões presentes diz respeito ao teatro e à música. Com o título «Teatro», J. Alves Mateus, depois de uma breve referência aos legados da Grécia e de Roma, fala-nos um pouco da arte dramática, de Gil Vicente e de António Ferreira, para A. Luciano nos fazer uma apreciação ao drama $A$ Prabidade de A. C. de Lacerda. Ainda no domínio do teatro, algumas referências ao teatro Académico e à actriz Emília Neves, por Vicente da Silveira.

Para além, das produções musicais referidas, de assinalar o texto intitulado "Belas Artes (Generalidades). Seu estado em Coimbra», onde se fala de música e se citam alguns nomes.

Com um certo interesse, dados os pormenores que se referem, é a abordagem que se faz de alguns temas históricos. A. M. Seabra de Albuquerque, em "Apontamentos Históricos», relata-nos notícias breves e curiosas do governo da Índia, em 1609, por parte de Rui Lourenço de Távora; fala-nos, também, da visita que D. Sebastião fez ao Mosteiro de Santa Cruz e das jornadas de África; relativamente à presença portuguesa no Norte de África, de referir «Fragmentos de uma carta de Lourenço Pires de Távora de Tangere, a El-Rei, sobre a batalha nos campos de Arzila, em que Bentuda ficou destroçado»; contrariando a opinião de Cadamosto, o mesmo Seabra de Albuquerque reflecte sobre «Os primeiros negros que vieram a Portugal», para, em «Estudos Genealógicos», indagar da ascendência dos duques de Palmela.

Ainda no âmbito da história e com o título de «Documento Curioso" e fazendo-se alusão a um opúsculo impresso em 1769 com o título de Colecção de leis promulgadas e sentenças proferidas nos casos da infâme pastoral do bispo de Coimbra, D. Miguel da Anunciação fala-se um pouco do Padre António Vieira e da Inquisição.

Outra das dimensões em evidência é a que respeita à educação e instrução. 276 No artigo intitulado mesmo «A Educação» reconhece-se que esta é o mais poderoso motor da civilização. Daí a sua necessidade e importância.

A educação familiar é uma das tónicas em apreço. Reflectindo sobre ela evidencia-se também a importância que a igreja e o clero devem ter nesta matéria, quando se escreve: «criai sacerdotes dignos e instruídos e tereis dado o passo mais gigantesco para a aniquilação do mau estado social» (n. o 2, p. 16, col. 1).

Intimamente ligado com esta matéria, Eduardo J. Coelho, em três artigos com o título "A Família e o Padre», depois de umas ligeiras considerações sobre felicidade e infelicidade no seio da família, reflecte, citando Michelet, sobre 
a influência, boa ou má, que o padre pode ter na família, para constatar que na educação do clero existem graves deficiências, cujas culpas não são só da classe, mas sobretudo dos poderes públicos que não realizam reformas.

Também Antero de Quental nos fala da necessidade de uma educação para o sexo feminino, no artigo «Educação das Mulheres».

Ainda no âmbito da educação e instrução, outra das tónicas é a que diz respeito à instrução popular. Em «Leituras populares», reconhece-se que a situação da instrução popular em Portugal vai «remissa e vagarosa» (Idem, vol. II, n. ${ }^{\circ}$ 2, p. 9, col. 2). Apontam-se algumas das causas deste nosso atraso, ao mesmo tempo que se defende uma ilustração para os agricultores e a importância que, nesta matéria, tem a implementação de associações e a escolha de bons livros. Citam-se como bons exemplos Estudos sobre a Reforma em Portugal de Henriques Nogueira que tem «um primeiro e eminente lugar na nossa... bibliotecazinha popular «(Idem, n. ${ }^{\circ}$ 3, p. 18, col. 1) e Felicidade pela Agricultura de António Feliciano de Castilho.

Quanto à organização da nossa instrução e num artigo de primeira página com o título "Aos nossos Colegas da Universidade de Coimbra", defende-se, contra a opinião do governo, a manutenção, em Coimbra, do Conselho Superior de Instrução Pública, bem como a sua composição e estrutura, para, depois, em "Revista», que é uma espécie de crónica, se vir a referir a extinção daquele órgão e se darem retratos do que a este propósito disse a imprensa de Coimbra e a de Lisboa e também o que se passou no Parlamento.

Em matéria de aproveitamento escolar e ainda em «Revista», alude-se aos êxitos e aos fracassos dos estudantes nos exames. Depois de algumas palavras sobre a matéria, defende-se, em termos de pedagogia, uma relação estreita entre professor e aluno, de tal modo que o estudante não veja no mestre senão um amigo e este considere o estudante como um filho. Então, «a apreciação será a mais justa possível» (Vol. I, n. ${ }^{\circ}$ 16, p. 182, col. 2).

No campo social e moral é de referir o artigo assinado por Eduardo J. Coelho com o título de «Os enjeitados e as rodas», onde se reflecte sobre problemas vários da sociedade, nomeadamente questões de infanticídio e da mulher, para se concluir pela necessidade económica, política e moral da existência de uma instituição, não importa o nome, desde que se alcancem os fins desejados.

Neste âmbito, também, A. M. da Cunha Belém reflecte sobre o problema do celibato entre os sacerdotes, no artigo «Do Celibato Eclesiástico». 
No domínio das Ciências da Natureza, é A. Filipe Simões quem, no artigo "O Homem e os Vegetais», nos fala do desenvolvimento da Humanidade, das conquistas que o homem operou na natureza, nomeadamente das modificações ao nível da vegetação florestal e nos aponta alguns dos meios utilizados para a difusão de muitas espécies.

Como não podia deixar de ser, Coimbra, a Universidade e a Academia estão igualmente presentes. É Vicente da Silveira quem, na primeira página de alguns números e sem qualquer título, nos dá imagens da vida coimbrã, para, em «Revista», nos fazer breves descrições, espécie de crónica, sobre as festas do Espírito Santo, as fogueiras do S. João, a procissão do Corpo de Deus, acontecimentos académicos e tecer algumas reflexões sobre a vida estudantil. É, todavia, A. F. de Loureiro quem, em «Um amor de estudante», foca uma certa singularidade do estudante de Coimbra.

Intimamente relacionada com a Academia está a Sociedade Filantrópica Académica. Para a sua história, aqui se publica o Relatório da direcção desta sociedade, apresentado pelo seu secretário, o Exm. ${ }^{\circ}$ Senhor António dos Santos Viegas Júnior, na ocasião da posse da nova direcção para 1859 e, em «Duas palavras sobre a Sociedade Filantrópica Académica», se lhe tecem algumas críticas, por não estar a cumprir, correctamente, a missão para que foi criada, muito por causa da «falta de energia e actividade, que em todas as suas direcções tem havido» (n. ${ }^{\circ} 7$, p. 75 , col. 2), já que não fazem a cobrança das cotas mensais e atribuem mesadas a quem não carece delas.

Completam este periódico, sobretudo ao nível do $10^{\circ}$ volume, algumas curiosidades interessantes. Para além das secções de «Charadas» e de «Máximas e Pensamentos», é de referir "Contrastes entre o Oriente e o Ocidente». Aqui se alude a situações diversas de que salientamos a seguinte: «Entre os tur278 cos a barba crescida é sinal de dignidade; entre nós de negligência e desalinho» (n. ${ }^{\circ} 11$, p. 129, col. 1). 


\section{4 • PRISMA}

Periódico da Academia Dramática de Coimbra

Coimbra, Imprensa da Universidade

1 Setembro1842 - Fevereiro 1843
Cotas:

$\mathrm{BN}$ : -

BGUC: -

BPMP: -

BMC: GHC - 20/10

Colaboradores: J. F. de Serpa, João de Lemos, José Borges Pacheco Pereira, C. Monteiro, J. J. de Melo, João de Azevedo, A. J. G. Lemos, Aires Pinto de Sousa de Mendonça e Meneses, J. da Silva Pereira e Manuel da Cruz Pereira Coutinho

Formato: $20 \times 26,5 \mathrm{~cm}$

Periodicidade: Não indica

Preço: Não indica

Páginas: $40+16^{(1)}$

\section{Objectivo}

«Dizem por aí que a nossa terra portuguesa está povoada de jornais, e dizem-no como de mofa! Mesquinhos! Se falassem só desses que enristram a lança dos partidos contra o coração da pátria, embora, que lhes sobrava razão, mas que se riam dos ceifadores afadigados na rica messe literária por lhes dar o pão do saber, é de loucos, de ingratos...

Sem curarmos dessa mofa das turbas, vamos hoje colocar também a nossa pedra no soberbo edifício, em que trabalham tantos obreiros ilustres: será ela pequena, tosca, mal jeitosa; todavia levará aninhado, nas sinuosidades e côncavos de seu corpo grosseiro um anelar ardente pelo bem da nossa terra, umas gotas de suor das frontes de mancebos, que nos escusem a míngua de melhor estreia...

Conta já a nossa Academia Dramática cinco anos de vida; e no meio deste século transitório e ligeiro, que por nós vai correndo, largo viver é este. Carece todavia, mal sazonado fruto de árvore moça, de quem lhe ampare os ramos,

(1) As 16 páginas correspondem à Revista do Distrito, tendo os n. ${ }^{\text {os }} 1$ e 2 sido publicados em conjunto. 
lhe regue o tronco, lhe dirija a nutrição. Este será o primeiro mister do nosso jornal.

Conhecemos que a melhor bandeira nos acolheramos, se em vez de tomar por objecto a universalidade tão variada da literatura, nos limitássemos à primeira necessidade e fim da Academia Dramática, o aperfeiçoamento do nosso tão desprezado teatro português; e fora meio muito de louvar a criação de um repertório não só de peças nacionais, mas do que há por aí de aproveitável no teatro das nações cultas, que substituísse essas nojentas versões de mal escolhidos dramas, que tanto vogão infelizmente por esse reino...

O título que escolhemos ainda é uma prova da nossa humildade; sem forças para misturar as cores da literatura, não podemos pôr na praça uma formosa tapeçaria; contentamo-nos com patentear o instrumento, que sempre dará ao menos os sete raios, ainda nas mãos do idiota, embora pudesse nas de um sábio conduzi-lo a mil combinações.

A literatura será o sol que havemos sujeitar ao nosso Prisma, e quedar-nos-emos folgando todas as vezes que uma de suas cores alegrar os olhos daqueles, que não adormecem alegres no meio das ruínas, nem escutam ainda a voz rouca da licença e da irreligião.

Não fazemos promessas.... seremos o que formos, o que podermos ser, que esta é a verdade melhor e menos perigosa de aventar» (n. ${ }^{\circ} 1$, p. 1).

\section{Conteúdo}

Tratando-se de um periódico ligado à Academia Dramática, são seus propósitos contribuir para o engrandecimento e objectivos daquela associação, não só através de reflexões sobre o teatro, mas também e sobretudo da literatura. Daí o carácter fundamentalmente literário que esta publicação apresenta.

A colecção completa desta publicação é de cinco números, todos com o mesmo formato e número de páginas. Publicada à parte destes números, mas fazendo parte deles, e com quatro páginas cada, há que acrescentar uma folha informativa e noticiosa intitulada Revista do Distrito «onde se poderão ler as peças oficiais mais importantes do Governo Civil, que interessam ao público... e em seguimento contaremos algum facto mais notável do distrito de qualquer natureza, que seja, ou a notícia de tudo, que interesse saber-se por sua utilidade» (Revista do Distrito, $\mathrm{n}^{\text {os }} 1$ e 2, p. 1, col. 1). Neste sentido, aqui se publica o 
Regulamento Provisório do Governo Civil de Coimbra, se dão a conhecer, entre outros assuntos, editais vários do mesmo Governo Civil, o modo de localizar, rapidamente, os incêndios em Coimbra, o movimento da roda dos expostos do Concelho de Coimbra, de acordo com o Regulamento de 12 de Maio de 1839, publicações literárias e notícias várias e diversas.

A dimensão literária deste periódico está patente em textos em prosa como, por exemplo, no romance, não concluído, de J. de Lemos e intitulado «Maria Pais Ribeira», em «Bonaparte», que é uma tradução de uma meditação poética de Lamartine, mas também em poesias várias.

Repartido por dois números, um artigo sobre o nosso teatro, da autoria de J. F. de Serpa intitulado «Teatro Português». Aqui se fala do que são as nossas salas de teatro [referências ao S. João no Porto, Bairro Alto, Condes e Salitre, em Lisboa, e ainda aos teatros da província, a que chamam "casas de comédia» (n. ${ }^{\circ}$ 1, p. 5, col. 2) ]; recorda-se, depois, o teatro do tempo de Gil Vicente, Sá de Miranda e António Ferreira e a restauração de 1640 que «também não soube reanimar a nossa literatura [teatral] fanada» (Idem, p. 6, col. 2); palavras para a influência francesa ao longo do século XVIII e princípios do XIX, para, finalmente, se concluir com a importância que teve o Conservatório Real de Lisboa, os esforços de Garrett e a acção do Conde de Farrobo, um «incansável amigo dos nossos estabelecimentos teatrais» (n. ${ }^{\circ}$ 2, p. 14, col. 2).

No domínio da História de Portugal há a referir a publicação de uma carta, datada de 14 de Junho de 1557, de Frei Tomé de Jesus aos seus religiosos, onde se fala da doença, morte e enterro de D. João III; neste domínio ainda e no texto «D. Nuno Álvares Pereira», dá-se conta do modo como o povo de Lisboa e seu termo veneravam o Santo Condestável, segundo se relata numa memória manuscrita de autor desconhecido.

Reflexões sobre problemas de educação e ensino, nos artigos intitulados «Instrução Pública» e «A reforma das escolas cirúrgicas e a gazeta médica do Porto». Se, naquele se reconhece que a organização da instrução pública tem muito a ver com uma estrutura social, se reflecte sobre a sua organização, se fala da instrução em países estrangeiros, para, finalmente, se afirmar que «a instrução popular... deve ser gratuita» (n. ${ }^{\circ}$ 5, p. 34, col. 2), a secundária «se não completamente gratuita, de tão fácil acesso deve ser, que o maior número a possa 
utilizar» (Idem), para que na superior « se dificulte, porque a sociedade pede fortes garantias aqueles de quem confia seus mais preciosos interesses» (Idem), já no segundo artigo se fazem algumas reflexões sobre um projecto de reforma nas escolas cirúrgicas, da autoria do deputado J. M. Grande e do eco que teve na gazeta médica do Porto.

Completa-se este periódico com a publicação do movimento académico da Universidade, no ano lectivo de 1841-42, com a relação dos alunos que ganharam os prémios e acessit, no mesmo ano, e um conjunto de «Máximas», onde se destacam os nomes de Lord Byron, Chateaubriand, Benjamin Constant e Pitágoras, entre outros. 


\section{5・O PUBLÍCOLA}

Jornal Semanário

Coimbra, Tip. da Rua dos Coutinhos ${ }^{(1)}$

15 Maio 1823 - 29 Maio 1823
Cotas:

BN: J. 1295 P.

BGUC: $\mathrm{R}-5-13$

BPMP: -

BMC: GHC -3

Redactor: José Joaquim Almeida Moura Coutinho

Formato: $10 \times 15 \mathrm{~cm}$

Periodicidade: Semanal

Preço: Não indica

Páginas: 48

\section{Objectivo}

"Inimigo dos déspotas e amigo do Povo como sou, tratarei unicamente de objectos que lhe forem úteis e servir-lhe-ei de escudo contra as prepotências e ataques do despotismo.

Posto que o Povo pode ser forte, poderoso e respeitado... é pois do dever dos que se presumem seus amigos declarar com franqueza: o que o Povo é, o que o Povo pode $=$, e cioso defender seus direitos e regalias contra quaisquer opressões.

Qual outro Valério eu adopto o título de Publícola; porque me julgo como ele amante do Povo, e por conseguinte da sua liberdade e felicidade; não escolhi o de Amigo do Povo, porque em França Marat, monstro vendido ao Duque de Orleans, fez odioso este nome. Se não desempenhar, como desejo, a tarefa de que me faço cargo, não será por falta de justiça e rectidão, pois hei-de procurar destruir o vício e defender a virtude. A imparcialidade e incorruptibilidade será a minha divisa. Praza aos céus, que nunca se aparte da estrada que uma vez principiou a trilhar e possa por isso merecer a estima de seus concidadãos». (n. ${ }^{o} 1$, p.p. $\left.3-4\right)$.

(1) O n. ${ }^{\circ} 1$ foi impresso na Tipografia da Rua dos Coutinhos. Os nos. 2 e 3 ostentam o nome de Tipografia Nova, mas que é a mesma da Rua dos Coutinhos. 


\section{Conteúdo}

O Publícola é um pequeno periódico, sucedâneo de o Minerva Constitucional, e cujo objectivo principal é denunciar os inimigos do liberalismo.

A colecção completa deste periódico é de três números, todos com o mesmo formato e número de páginas. A estrutura interna é a mesma em todos os números.

Três grandes temas dominam neste periódico. $\mathrm{O}$ primeiro diz respeito à educação e à instrução, que se desejam ver modificadas. Aqui se reconhece a necessidade e a importância da educação e da instrução, pois sem elas «não podem haver bons costumes e estes são a base fundamental da felicidade das Nações» (n. ${ }^{\circ}$ 1, p. 5); faz-se, depois, uma forte crítica ao governo do despotismo, porque «não se propõe senão a reter os homens na estupidez, a dividi-los, para mais facilmente os subjugar» (Idem); alude-se e fazem-se algumas reflexões ao projecto que Luís da Silva Mousinho de Albuquerque apresentou às cortes com o título de Ideias sobre o estabelecimento da Instrução Pública, ao qual o redactor deste periódico adere, mas introduzindo-lhe algumas modificações; tecem-se, finalmente, considerações e avançam-se algumas propostas concretas para o ensino primário, secundário e superior.

O segundo tema diz respeito a uma questão de filosofia política, que nos remete para uma certa concepção de liberalismo. No contexto da monarquia constitucional, trata-se de opinar sobre a existência ou não de um bicamaralismo e se o rei deve ou não ter veto absoluto. Depois de algumas reflexões, Almeida Moura, no texto «Devem haver duas Câmaras? Deve o rei ter veto absoluto?", conclui que a existir uma segunda câmara ela é «para censurar as leis da primeira» (n. ${ }^{\circ} 2$, p. 24) e o veto absoluto «é uma monstruosidade política» (n. ${ }^{\circ} 3$, p.34).

284 Apontam-se algumas inconveniências do veto absoluto.

O terceiro tema tem a ver com a defesa da liberdade, da inteligência, da revolução e do constitucionalismo. É este o sentido a extrair de textos como "Esforço dos corcundas», "Assembleia dos Amigos do Tenebrosíssimo Astaroth», "Conclusão da sessão 1 1a dos Amigos do Tenebrosíssimo Astaroth» e «Os triunfos da liberdade». Aqui se tecem fortes críticas ao despotismo político, a todos os reaccionários, que, identificados com o «corcunda», «trazem na boca a religião e no coração a perversidade» (n. ${ }^{\circ} 2$, p. 29) e, por isso, acusam os liberais de provocar distúrbios. Utilizando a figura do diabo (Astaroth) tecem- 
se, também, fortes críticas ao clero, que, «cobrindo-se com o véu da religião faziam-se déspotas ainda mais temíveis, porque dirigiam nossas consciências» (n. ${ }^{\circ} 3$, p. 37) e a alguns professores da Universidade, sobretudo aos das Faculdades Jurídicas, quer pela ignorância que demonstram, quer pelas concepções absolutistas que ostentam e defendem: «Já aqui se ouve falar em palavras da constituição? Isso não presta. Quem ousou dizer que a lei era igual para todos?... Desterremos dentre nós iguais princípios não só porque são contrários à justiça, que nós adoptamos, mas porque sua doutrina é prejudicial a nossos interesses» (n..$^{\circ}$ 3, p.p. 42 e 43). Citando exemplos históricos como o caso dos Holandeses e Ingleses e as garantias consignadas na Magna Carta, afirma-se a voz dos povos a clamarem justiça e liberdade: «Nós seremos livres e levantaremos o pendão da liberdade no meio de Paris» (Idem, p. 42).

Completa-se este periódico com «Notícias», onde se dão pequenas informações e notas sobre o que se vai passando em várias partes da Europa.

Bibliografia: Luís Reis Torgal, «A imprensa estudantil de Coimbra e o radicalismo liberal vintista», O Liberalismo na Península Ibérica na primeira metade do século XIX. Comunicações ao Colóquio organizado pelo Centro de Estudos de História Contemporânea Portuguesa, 1981, Coordenação de Miriam Halpern Pereira, Maria de Fátima Sá e Melo Ferreira e João B. Serra, 2. ${ }^{\circ}$ vol., Lisboa, Sá da Costa Editora, 1982, pp. 241-56; Luís Reis Torgal e Isabel Nobre Vargues, A Revolução de 1820 e a instrução pública, Porto, Paisagem Editora, 1984, pp. 275 e ss. 


\section{$106 \cdot$ O RAIO}

Coimbra, Tipografia Operária

1894 (entre Fevereiro e Maio)

Director: António José de Almeida

Colaboradores: João de Freitas, Fernão Silvestre, Carlos de Lemos, Sá Couto

Formato: 15,5 x $22 \mathrm{~cm}$

Periodicidade: (1)

Preço: 30 réis

Páginas: 30
Cotas:

BN: J. 964//14 P

BGUC: O.S. 605

BPMP: -

BMC: GHC $-19 / 6$

\section{Objectivo}

«Em primeiro lugar. Este jornal é, numa nova arena de combate, o lidador colectivo dos restos até aqui dispersos duma legião vencida.

No grupo que ele representa há aspirações diferentes. Uns são pela República e ficarão com ela. Outros, pugnando por esse ideal político que lhes é uma solução provisória, avançarão depois... Mas numa coisa estamos concordes: dar a ousadia do nosso braço e do nosso espírito à proclamação da República em Portugal...

Alguns de nós representam, pela tradição e pela solidariedade, um numeroso grupo de revolucionários que a cobardia e a traição tem dizimado. Constitui-se espontaneamente em 11 de Janeiro de 90. A princípio lutou romanticamente: com rumo, mas quase sem nexo... Mas José Falcão morreu... A barca republicana lá ao largo, no mar alto, sob um temporal desfeito, começava a lutar desvantajosamente com as ondas iradas...

Sentimos apagada a vida nacional e dentro de nós congelar-se a esperança num futuro melhor.

Primeiro período de desalento...

Ficámos isolados...

Cá somos portanto numa nova abalada para a guerra...

(1) Na última página da publicação lê-se: «O Raio não tem dia certo de publicação». 
Eminentemente pitoresca a actual situação política de Portugal...

Excessivamente risível e lúgubre a vida nacional...

Por esse pais além, as arcas são vazias e as almas desertas. Os braços sem trabalho, as inteligências incultas, o coração sem abalos, a consciência sem iras. Uma Pátria que atrasou na sua evolução histórica, encalhada na areia. Uma sociedade falida, sem coração e sem cérebro, desconfiada e má, sem energia e sem fé, - mordendo-se e cuspindo-se...

Contra este estado de coisas saímos nós - querendo a solidariedade com a falange que, lá de ao longe, vem avançando contra as muralhas da velha lei e da velha ordem» (O Raio, n. ${ }^{\circ}$ 1, Coimbra, 1894, p.p. 3-6).

\section{Conteúdo}

Nos artigos de $O$ Raio perpassam dois grandes temas. O primeiro diz respeito à situação geral do país: João de Freitas em artigo «O partido republicano e as eleições», não só denuncia o acto eleitoral em si mesmo, porque, por motivos vários, «é tudo quanto há de mais torpe e degradante» (p. 9), mas também dirige críticas ao partido republicano, em virtude de terem sido afastadas da direcção pessoas capazes e substituídas, por «alguns ambiciosos parvenus e por intrigantes mesquinhos» (p. 12).

Carlos de Lemos, em artigo sem título, reflecte sobre o estado do país e a sociedade do tempo, dizendo que Portugal está «morto no tempo; vivo na Eternidade» (p. 18);

Sá Couto, em «A maré sobe», fala-nos da falta de liberdade de informação: «Quizera agora escrever com fogo; não posso porém: pró́be-mo o cego furor do penteado e esguio João Franco...» (p. 25).

O segundo grande tema diz respeito ao Centenário do Infante D. Henrique.

A estrutura deste pequeno periódico completa-se com «Em Bivaque», onde há lugar a um conjunto de notícias várias. 


\title{
107 • A REACÇÃO
}

\author{
Revista Literária Cotas: \\ Coimbra, Tip. Luís Cardoso BN: \\ 1 Novembro 1893 - 3 Abril $1894 \quad$ BPMP: XI I- 3 - 34(A) \\ BMC: GHC -2
}

\begin{abstract}
Director: Gustavo Santiago
Colaboradores: Carlos de Lemos, Guedes Teixeira, Alberto Pinheiro Torres, Mário Alves, José Sarmento, Rodrigues Davim, Pinho de Almeida, Luna Freire, Coelho Neto, Demétrio Toledo, Cândido Pena, Raimundo Correia, Alberto de Oliveira, Plácido Júnior e Artur Lobo

Formato: $13,5 \times 21 \mathrm{~cm}$

Periodicidade: Não indica

Preço: Doze Números -500 réis $\bullet$ Avulso -50 réis

Páginas: 96

Tiragem: 400 exemplares ( $\left(1^{\text {a }} \mathrm{ed}\right.$.)
\end{abstract}

\section{Objectivo}

«A Reacção propõe-se quebrar a apatia do nosso meio literário, fazendo sair das pastas o que de bom nelas haja, que o há. É pois, uma reacção literária, unicamente hostil às ideias más, ou melhor, à falta de ideias.

Acolhemos de braços abertos todos os talentos e atacamos, na medida das nossas forças, todas as nulidades.

É este o nosso programa: empenharemos todas as nossas energias para que

288 "A Reacção» o cumpra fielmente» (A Reacção, 2.a Edição, n. ${ }^{\circ}$ 1, Novembro de 1893, contra-capa).

\section{Conteúdo}

A Reacção é uma pequena revista literária, cuja colecção completa não foi além de seis números, todos com o mesmo formato e número de páginas. De salientar que, do n. ${ }^{\circ}$ 1, se fez uma segunda edição. 
Aberta a todos os que desejassem mostrar os seus talentos literários e sem preferência por qualquer escola literária, inicialmente, era seu objectivo lutar contra uma certa apatia literária que, segundo Gustavo Santiago, reinava no meio estudantil, em virtude de, «numa terra quase de estudantes, jornal académico algum havia, club algum existia, onde se reunissem aqueles dos poucos amantes das letras» (n. ${ }^{\circ} 2$, p. 28). Não admira, por isso, que Carlos de Lemos, no texto intitulado "A última semana do Advento", procure tecer algumas considerações e louvores à poesia e seus criadores. Se «poesia é harmonia» (n. ${ }^{\circ} 1$, p. 6), já o poeta «é o homem do futuro» (Idem).

Nesta primeira fase, é, sobretudo, a prosa de Alberto Pinheiro Torres, em «Prólogo», de Pinho de Almeida, em «Do «Evangeliário»", e a poesia de Guedes Teixeira que marcam, literariamente, esta publicação. A preferência por uma literatura decadentista é, aqui, evidente.

A partir de Janeiro de 1894, em uma nova fase, afirma-se esta revista contra o movimento dos novos poetas, nomeadamente, «essa meia-dúzia de transviados, a que chamaram e chamam, em conjunto, nefelibatas» (N.o 3, p. 46). Esta mudança explica, certamente, a saída de alguns colaboradores como Guedes Teixeira, Carlos Lemos e Pinheiro Torres e a entrada de outros, sobretudo de brasileiros, como Coelho Neto, Demétrio Toledo e Raimundo Correia que agora dominam.

Nesta segunda fase, que o próprio director classifica como "período de agitação, de luta» (n. ${ }^{\circ}$ 3, p. 47), salientamos a rubrica, «Na Brecha», de Cândido Pena, onde este colaborador tece algumas considerações menos abonatórias a uma certa imprensa - O País, do Rio de Janeiro, e Correio da Manhã-, por não identificarem e referenciarem, correctamente, matérias utilizadas. Também aqui se fazem críticas e assumem divergências de pensamento relativamente a Teófilo Braga e Armando Navarro, a quem chamam «homem de ciência feito à pressa» (n. 3 , p. 43), por causa das concepções que revelou sobre poesia e arte, no artigo que escreveu na revista Os Novos.

Finalmente, em «Bibliografia», noticiam-se publicações, referenciam-se as recebidas e dá-se, também, conta de matérias incluídas em algumas. 


\section{8 - O RECREIO}

Folha quinzenal, literária e noticiosa

Coimbra, Imprensa Literária

19 Fevereiro 1879 - 2 Abril 1879
Cotas:

BN: J. 1656//16 V.

BGUC: -

BPMP: -

BMC: GHC -20/10

Administrador: C. P. Urze

Redactores: Júlio de Magalhães e Armando do Vale

Colaboradores: J. Nunes Gonçalves, Alberto Gomes,

Eduardo Martinez e F. Rijó Rosado

Formato: 26,5 x $35 \mathrm{~cm}$

Periodicidade: Quinzenal

Preço: Mês - 100 réis

Páginas: 4

\section{Objectivo}

Não indica.

\section{Conteúdo}

$O$ Recreio é um pequeno e modesto periódico, que surgiu, certamente, na sequência de desinteligências havidas na equipa de $O$ Astro da Juventude, dirigido por Lima Duque. Segundo nos informa Carneiro da Silva (Ob. cit., p. 113), o n. ${ }^{\circ} 3$ de $O$ Astro da Juventude estaria pronto a sair, quando surgiram as desavenças. Então, Lima Duque resolveu trespassar o jornal, que veio a publicar-se com o título de $O$ Recreio. É também esta a ideia e o sentido que ficam da informação nele expressa: «Por motivos muito particulares, deixou de redigir esta folha o nosso prezado amigo e talentoso colega o Senhor Aadel (Abílio Albano de Lima Duque). Passou a redacção, bem como a propriedade do Astro da Juventude para novas mãos» (n. ${ }^{\circ} 1$, p. 2, col. 2).

Trata-se de uma pequena publicação, cuja colecção completa não foi além de quatro números, todos com o mesmo formato e número de páginas, de alunos de instrução secundária, cuja finalidade é, não só literária, mas também noticiosa, formativa e recreativa. 
O sentido literário afirma-se, sobretudo, em pequenos textos, em prosa e verso, como, por exemplo, os contos da autoria de Júlio de Magalhães. De referir também, «A noiva», de Alberto Gomes e, «Num cemitério da aldeia», de Eduardo Martinez. Ainda neste contexto, um pequeno artigo sobre literatura portuguesa intitulado mesmo «Fases por que tem passado a literatura portuguesa», onde o seu autor, depois de umas breves considerações sobre a nossa língua, nos dá um retrato breve da literatura portuguesa, nas suas diversas fases.

O carácter noticioso afirma-se, fundamentalmente, em «Noticiário» que é uma secção permanente do periódico, onde são divulgadas notícias múltiplas.

O contributo formativo inscreve-se, sobretudo, em pequenos e simples artigos sobre problemáticas várias. É Armando do Vale quem, em «A Instrução Popular e a sua influência no futuro», reflecte, não só sobre a importância desta matéria para os povos, mas defende, sobretudo, a existência de professores sabedores, de bons programas, bons livros, o culto da educação física nas escolas e que estas tenham as melhores condições para atrair os alunos; o tema da imprensa é abordado por J. Nunes Gonçalves, no pequeno artigo com o mesmo título de "A Imprensa»; em «O Socialismo», o seu autor fala-nos das ideias principais desta doutrina e sua conexão com a religião.

Finalmente, o carácter recreativo passa, não só na secção permanente de «Charadas», mas também pela leitura de um pequeno folhetim. 


\title{
109 - RECREIO JUVENIL
}

\author{
Semanário de Literatura Cotas: \\ Coimbra, Tip. J. T. A. Pacheco BN:- \\ 1 Julho 1858 - 16 Setembro 1858 BGUC: - \\ BPMP: - \\ BMC: GHC -2
}
Colaboradores: A. A. de Oliveira Vale, J. Simões
Ferreira, A. A. da Fonseca Pinto, Augusto
Sarmento, A. J. S. Ferreira Carvalho, J. do Patrocí-
nio Costa, A. Filipe Simões, P. A. Martins da
Rocha, A. C. da Silva Matos, Luís Pereira
Abranches e M. Adelino de Figueiredo
Formato: 16,5 x $22 \mathrm{~cm}$
Periodicidade: Semanal
Preço: Trimestre - 300 réis
Páginas: 96

\section{Objectivo}

«Que ideia fazeis vós do que será o Recreio Juvenil? Qual foi o primeiro pensamento que vos ocorreu quando leste o modesto título deste jornalinho? Talvez que era uma especialidade literária, original no pensamento e na forma, dedicada tão somente a dissertar sobre papagaios, piões, cavalinhos de cana e quejandos infantis divertimentos? Pois não é. E se o fosse, negar-lhe-ieis a utilidade?...

Do modo como for educada a geração que nos vai seguir, depende essencialmente o futuro da terra que nos viu nascer. Na nossa mão, pois, está,

292 dirigindo-a, preparar de rosas esse futuro, ou descuidando-a, vê-lo enegrecer infalivelmente...

Só na infância está a esperança de regeneração; em prol dela devemos trabalhar.

Jornais que tratem assuntos mais sérios há-os por aí, e não são poucos, mercê de Deus; mas tão sérios são, que crianças os não entendem...

O Recreio Juvenil não é, por ora, esse jornal, literalmente falando. Não desconhecemos que para desempenhar a contento nosso aquele propósito nos é necessário estudo peculiar e maiores habilitações literárias, que por enquanto 
nos não assistem: não esmorecemos todavia, e ainda nos alenta esperança de algum dia o podermos fazer, se não tivermos a infelicidade do público desfavor.

Desde já este jornalinho procurará granjear estima e aceitação, não por consumada mestria no desenvolvimento das matérias, senão pelo cuidado e esmero com que fugirá assuntos estéreis ou demasiadamente pesados.

O seu programa resume-se numa palavra-variedade: outra determina o seu fim-utilidade: uma terceira significa os meios-amenidade.

Sobre esta trindade assentaremos uma enciclopediazinha, que, tratando tudo, será para todos, sem ser determinadamente nem para o sábio nem para o literato, para o artista, nem para o agricultor.

A Religião, a História, a Geografia, a Agricultura, a Economia, a Química, a Física, a História Natural, as Belas-Artes mas tudo isto em generalidades fugitivas, sem se elevar nunca às grandes alturas científicas...; o romance e a poesia virão depois...» (n. ${ }^{0} 1$, p.p. 1 e 2 ).

\section{Conteúdo}

Trata-se de um pequeno jornal de alunos da instrução secundária, cujo objectivo principal é divulgar o maior número de conhecimentos, para uma máxima cultural. Daí o carácter enciclopédico, a preocupação utilitária e a afirmação de simplicidade com que este periódico se apresenta.

A colecção completa é de doze números, todos com o mesmo formato e número de páginas.

Para além de alguma produção literária traduzida, fundamentalmente, no romance «Emília», da autoria de J. Simões Ferreira e algumas poesias, as restantes matérias, em pequenos e simples artigos, inscrevem-se no âmbito das disciplinas deste nível de ensino, repartindo-se, assim, por diversos ramos do saber:

- Religião: para além da evocação de alguns quadros bíblicos como o dilúvio reflecte-se sobre a irreligiosidade do século;

- História: conceito e importância da história; referência à administração no reinado D. José;

- Química: a história da pólvora;

- Física; o fenómeno das auroras boreais; 
- Literatura e jornalismo: depois de uma breve referência à história da literatura, alude-se à importância que têm os jornais literários e a obrigação que há em os proteger e acarinhar;

- Economia Política: o interesse e a importância dos conhecimentos económicos;

- Belas-Artes: depois de umas breves considerações, faz-se, no domínio da escultura, a apreciação de um baixo-relevo de Eduardo da Fonseca e Vasconcelos; no âmbito da poesia épica, fala-se de Homero, Virgílio e da Eneida;

- História Natural-Botânica: Filipe Simões fala-nos da planta Dionea Muscipula, vulgarmente conhecida pelo nome de apanha moscas;

- Agricultura/Revista Agronómica: para além de uma reflexão de carácter geral sobre esta matéria, há o propósito de, com esta rubrica, «sermos úteis à mocidade das classes menos instruídas da sociedade» (n. ${ }^{\circ}$ 1, p. 3, col. 2). Daí a importância, depois, da inclusão de uma Revista Agronómica, onde «daremos de hoje em diante uma notícia sucinta dos trabalhos agrícolas próprios da época, algumas regras gerais e noções teóricas e práticas, que lhes digam respeito, bem como uma informação geral sobre o aspecto que a agricultura for apresentando em vários pontos do reino, e com especialidade no nosso distrito» (n. ${ }^{\circ}$ 2, p. 10, col. 1).

No domínio da agricultura, de salientar ainda o pequeno artigo da responsabilidade de M. Adelino de Figueiredo intitulado «Agricultura. Causas do seu atraso em Portugal. Meios de a fazer prosperar».

Completa-se este jornal com três secções: «Comemorações», onde, como a própria palavra sugere, se vai dando conta, relembrando acontecimentos vários, como, por exemplo: a descoberta da Madeira, a partida de Vasco da Gama para a Índia, o nascimento de Camões e Diogo de Bernardes, a tomada de Ceuta, a conquista de Quíloa, etc.; «Variedades», que é um espaço reservado a notícias, 294 informações e curiosidades como: a descoberta de um cometa, quem foram os duques de Beja e qual o tempo médio de vida do homem, etc. e «Anedotas e Charadas». 


\section{0 - O REGENERADOR}

Número Programa ${ }^{(1)}$

Coimbra, Tip. Santos e Silva

19 Janeiro 1883 - 19 Fevereiro 1883
Cotas:

BN: J.1688//6V;

BGUC: J.3580//168M.

BPMP:

BMC: GHC -152

Redactor político: A. A. de Lima Duque

Colaboradores: Augusto Cândido Pereira de Lemos, Júlio Rocha e Adolfo Gustavo de Mendonça

Formato: $28 \mathrm{x} 43,5 \mathrm{~cm}$

Periodicidade: Semanal

Preço: Trimestre -500 réis

Páginas: 4

\section{Objectivo}

«Hoje que os republicanos tentam assoberbar com o seu sistema utopista as actuais instituições da monarquia... hoje que a arcaica facção dos miguelistas sonha em suplantar o governo liberal... não é de mais, na arena jornalística, um campeão, intransigente e devotado, que, à sombra da bandeira liberal, se infileire nas alas desse partido, cujo braço leal e esforçado, defende, com a constância de um herói, as instituições nobilíssimas da liberdade; guerreadas pelos fantoches das ideias avançadas, e pelas múmias fanatizadas do velho absolutismo...

O Regenerador conterá além da secção política, uma secção de literatura, outra noticiosa e outra de composições enigmáticas... Terá sempre folhetins, escolhidos e interessantes...» (Prospecto).

«Quase que se tornava desnecessário o programa da nossa folha, em face deste número que hoje sai a público.

A sua mira, as suas armas de combate, os vários assuntos de que se ocupará, tudo se deduz deste jornal - programa que sob o título de Regenerador, se apresenta, modestamente, à luz da publicidade.

(1) Os n. os 2 e 3 têm como subtítulo «Folha Política». 
Conterá, como deste número de depreende: - artigo de fundo, político; outros artigos políticos, secundários; resenha das novidades principais do mundo; assuntos literários; diversões charadísticas; notícias da localidade; anúncios diversos; e folhetim, nas duas primeiras páginas.

É este o programa da nossa folha; se ao que temos mencionado, se juntar a afirmação do nosso amor à causa dos princípios liberais; e a nossa vontade, tão nobre quão sincera, de proteger o bem-estar dos nossos compatriotas, e a independência do país, que nos foi berço, no seio das contínuas dissenções, que se agitam na Europa» (n. ${ }^{\circ}$ 1, p. 1, col. 1).

«Este número e os seguintes não terão, como o número programa, secção de enigmas e a sua parte literária não será obrigatória: em compensação aumentaremos quanto pudermos o noticiário e acrescentaremos uma série de telegramas, e algumas correspondências de várias localidades» (n. ${ }^{\circ}$ 2, p. 4).

\section{Conteúdo}

À semelhança de outros, $O$ Regenerador é um periódico que podemos classificar como de político, na medida em que se afirma como um órgão doutrinário de uma determinada tendência. Como o próprio título sugere, aqui se faz a defesa do partido regenerador e, consequentemente, se denunciam os propósitos e acções das outras forças partidárias, que, no dizer do responsável deste jornal, «são um estorvo ao passo do gigante» (n. ${ }^{\circ}$ 2, p. 1, col. 1).

A colecção completa desta publicação é de três números, todos com o mesmo formato e número de páginas. A primeira página é, na sua maior parte, dedicada ao artigo de fundo, seguindo-se-lhe, depois, um conjunto de pequenos textos e rubricas várias, sendo uma parte da última página destinada à 296 publicidade.

É, sobretudo, ao nível dos artigos de fundo e de outros pequenos artigos, de carácter mais secundário, como, por exemplo, "Carta de Braga» (Cfr. n. ${ }^{\circ}$ 2, p. 2), «Galveias» (Cfr. n. ${ }^{\circ}$ 3, p. 2) e outros que a tónica política mais se evidencia. Depois de uma brevíssima panorâmica do país, no contexto da monarquia absoluta, de um louvor à acção governativa de Pombal, por ter sido ele quem lançou «o alicerce de uma política inovada, sobre a qual as futuras gerações haviam de assentar o edifício social» (n. ${ }^{\circ} 1$, p. 1, col. 3), de uma evocação à 
independência da América e à Revolução Francesa, fala-se, depois, da revolução liberal portuguesa e de alguns dos seus momentos mais importantes como, por exemplo, o movimento da Regeneração. Foi deste movimento que derivou o nome do partido regenerador, porque era necessário «regenerar o reino português dando-lhe os melhoramentos que fossem necessários e as reformas que a utilidade financeira aconselhava e exigia» (n. ${ }^{\circ}$ 1, p. 2, col. 1), para, em seguida, se criticarem as outras forças políticas, sobretudo o partido progressista, nome irónico, porque, segundo este periódico, de progresso nada demonstra, uma vez que «sempre foram um obstáculo ao desenvolvimento material deste país... (e) combatem surdamente todos os actos do governo regenerador» (n. ${ }^{\circ}$ 1, p. 2, col. 2) e, por isso, são «os apóstolos da paralisia social» (n. ${ }^{\circ}$ 2, p. 1, col. $1)$.

Denúncias e críticas, também, para o partido legitimista, porque defende os velhos privilégios e para os republicanos, porque têm «ideias utopistas e vacilantes» (n. ${ }^{\circ}$ 2, p. 1, col. 1). A testemunhar este facto estão, não só os acontecimentos que se vão passando no Parlamento e que este periódico relata, mas também o que se passa em França, onde o partido republicano francês tem revelado, igualmente, posições contraditórias, pelo que «já não é permitido a ninguém ter ilusões» (n. ${ }^{\circ} 3$, p. 1, col. 4).

Para além de informações sobre o que se vai passando nas sessões parlamentares, completam este periódico secções permanentes como: «Recanto Literário», onde se dão a conhecer costumes indianos, se fala do Penedo da Saudade, da Sé Velha e de D. Sisnando; «Notícias Diversas/Estrangeiro», espaço, reservado a notícias e telegramas do que vai pelo país e pelo mundo e "Noticiário Local», com as novidades de Coimbra. Apenas no primeiro número, a «Secção Enigmática», com charadas e logogrifos.

De referir, finalmente, a existência de «Folhetim», que neste tipo de periódicos são importantes, porque, no dizer de Clara Rocha, eles podem servir para «aliciar o público leitor» (Revistas Literárias do Século XX em Portugal, Vila da Maia, Gráfica Maiadouro, 1985, p. 29). 


\section{1 • A RESTAURAÇÃO DA GARTA}

Jornal Académico de Coimbra

Coimbra, Imprensa da Universidade

4 Fevereiro 1842 - 18 Fevereiro 1842
Cotas:

BN: J. 209//3 B.

BGUC: $10-9-7$

BPMP: P/C/1078 (12)

BMC: GHC $-20 / 5$

Editor: José Ricardo P. de Figueiredo

Formato: 19 x $29,5 \mathrm{~cm}$

Periodicidade: Não indica ${ }^{(1)}$

Preço: Não indica

Páginas: 20 + suplementos

Observações: (2)

\section{Objectivo}

«No dia 30 de Janeiro de 1842 desafrontaram-se finalmente em Coimbra os seis anos do vergonhoso silêncio, com que havíamos sofrido a acintosa derribação da Lei fundamental do Estado, o desprezo à dignidade real, o enxovalho à filha do invicto Libertador, o furor desregrado dos progressistas, e a insolência da anarquia. O brado da restauração e liberdade, que tão alto havia retumbado no dia 27 pelas ruas da cidade invicta, veio após três dias repercutirse nas margens do Mondego com a mesma convicção e o mesmo entusiasmo. Graças à briosa Mocidade Académica, que a primeira em Coimbra levantou o grito restaurador de - Viva a Carta...

A página mais brilhante da nossa história nacional, superior... aos campos de Aljubarrota, foi sem dúvida o assédio maravilhoso do Porto, que assegurou a emancipação da Pátria à custa de tanto valor e de tanto sangue. E essa página

298 de ouro havia sido vergonhosamente manchada pelos homens de Setembro...

Não são os anarquistas, nem os revolucionários quem apregoa a restauração. São os amigos da Ordem os portugueses fiéis à Rainha, e os verdadeiros

(1) Não admira que assim seja, uma vez que se apostava em acompanhar e divulgar, o mais rapidamente possível, o evoluir do movimento restaurador. É isso que poderá explicar o facto de, num periódico pequeno e modesto, se contarem 4 suplementos.

(2) De referir que, para além do editor responsável, nenhum estudante se identifica. 
constitucionais, que reagem contra o efeito de uma revolução atraiçoada após seis anos de ansiedade...

Honra e Glória à cidade invicta, à nobre Junta, que dirige os desejos da Nação, ao bravo exército restaurador, aos pacíficos cidadãos e à briosa mocidade académica» (A Restauração da Carta, n. ${ }^{\circ}$ 1, p. 1).

«O título da nossa folha assás patenteava o nosso pensamento: eramos Cartistas - desejávamos a reintegração do Código de 26: tinhamos para nós, que nisso ia o bem da nação - amávamos instintivamente os princípios da Carta simpatizávamos com os seus nobres defensores: eram muito deles os nossos melhores amigos - julgamos, portanto, que não devíamos ficar silenciosos, sem que a taxa desairosa de contraditórios, egoístas, desleais e cobardes manchasse nossos nomes desconhecidos, e obscuros, mas virgens, porque nem o sangue de nossos concidadãos manchou ainda nossas mãos, nem o ouro do Estado seduziu nossas consciências.

Mal soou na cidade invicta o grito mágico de - Viva a Carta - veio logo repercutir-se em nossa alma, e corremos a estampar no papel as doces vibrações do nosso coração...

Hoje, porém, que a nossa causa recolhe os louros da vitória, congratulamo-nos com os nossos amigos, abraçamos os que cederam, consolamos os que erraram e respeitamos os que ainda se acham fora de nossas opiniões.

A nossa folha não morreu... suspendemos por ora a sua publicação, porque nem as nossas ocupações, nem a posição topográfica em que vivemos consentem a sua continuação" (Idem, n. ${ }^{\circ}$ 4, 18 de Fevereiro de 1842, p. 20, cols. 1 e 2).

\section{Conteúdo}

A Restauração da Carta é um pequeno e modesto periódico que surgiu, por iniciativa dos estudantes cartistas, com o objectivo de contribuir para a divulgação dos valores e princípios consignados na Carta Constitucional, em virtude do triunfo do golpe militar levado a cabo por Costa Cabral e pelo duque da Terceira, na cidade do Porto, em 27 de Janeiro de 1842.

A colecção completa deste periódico é de quatro números, todos com o mesmo formato, num total de 20 páginas, e outros tantos suplementos. Destes, um suplemento diz respeito ao n. 2 e os restantes ao terceiro número. É nestes suplementos que se dá conta da restauração da Carta na cidade de Beja, se 
noticia a formação do novo ministério, se anuncia que a Rainha determinou a entrada em vigor da Carta Constitucional e, finalmente, se referencia a presença do rei e da rainha num TE DEUM, em acção de graças.

Neste periódico perpassam duas grandes questões, que se interligam: a mais importante tem a ver com a reafirmação e defesa das ideias e princípios consignados na Carta Constitucional, de que é exemplo, entre outros, o texto intitulado "A Parábola»; a outra diz respeito às críticas que são movidas aos adversários da Carta, exemplificadas em passagens várias, ao longo do periódico.

À semelhança do que acontece no Evangelho, também no texto de «A Parábola», se faz a distinção entre os bons e os maus servos. Os bons servos identificam-se com os cartistas, que, quando o Senhor fez «soar a trombeta da restauração», logo se apresentaram e disseram: «Senhor estamos prestes», ao que o Senhor lhes respondeu: «Ide... e poreis a vossa mão direita sobre o túmulo de vosso pai, e dentro do vosso coração jurareis de arrancar a árvore profana; e como isto fizerdes, regareis com lágrimas de alegria aquela terra manchada, plantareis novamente a árvore de vosso pai, e abençoareis todos os vossos irmãos» (n. 2 , pp. 7-8, cols. 2 e 1).

Os maus são os homens e as ideias ligadas à Revolução de Setembro, que tão nobre e importante foi que «ainda não tem autor» (Idem, p. 6, col. 1). Os maus são o duque de Palmela, que, por isso, é alvo de críticas, é o governo de Lisboa, que acusam de «traiçoeiro e desleal» (n. ${ }^{\circ} 3$, p. 13, col. 1) e a imprensa da capital que «não cessa de estigmatizar o movimento da cidade heróica, alcunhando-o de revolucionário, injusto, impolítico e desacompanhado do mais pequeno vislumbre de utilidade, contrário à opinião pública, e em antagonismo com o senso comum» (n. ${ }^{\circ}$, p. 5 , col. 1).

De salientar ainda neste periódico a publicação de documentos oficiais como: o manifesto que a Junta Provisória dirigiu ao país; a declaração da mesma Junta, a dar por concluída a sua missão; as proclamações feitas aos soldados pelo barão da Ponte de Santa Maria, no início e fim do movimento restaurador e a Carta da Junta Provisória a conceder poderes ao Administrador Geral Interino do Distrito do Porto, José Bernardo da Silva Cabral.

Ainda ao nível de documentos, mas agora de carácter particular, a publicação da declaração de Joaquim António de Aguiar, opositor ao Setembrismo, 
datada de 23 de Setembro de 1836, dizendo estar «firmemente resolvido a não prestar o juramento, que se há-de exigir... como Conselheiro do Supremo Tribunal de Justiça» e tudo, porque «fiel aos ... princípios, aos ditames da ... consciência» (n. ${ }^{\circ} 4$, p. 19, col. 1).

Completa-se este periódico com notícias e descrições sobre as adesões ao movimento restaurador, a que chamam de «movimento nacional» (n. ${ }^{\circ} 2$, p. 5 , col. 2), em vários pontos do país. Uma atenção mais especial para o que se passou em Coimbra. 


\section{2 • REVISTA ACADÉMICA}

Jornal Literário e Científico

Coimbra, Imprensa de E. Trovão

15 Março 1845-1848

Redactores: João de Lemos Seixas Castelo-Branco, António Joaquim Ribeiro Gomes de Abreu, Joaquim Augusto Simões de Carvalho, Manuel Maria da Silva Bruschy, Pedro Nunes Leal, Isidoro Emílio Batista, José Vicente Barbosa du Bocage e Sebastião Frederico Rodrigues Leal ${ }^{(1)}$

Colaboradores: J. F. de Serpa, Luís de Bessa Correia, A. Lima, Alexandre Herculano, J. F. de Macedo Pinto, António de Serpa Pimentel, António Xavier Rodrigues Cordeiro, Pereira da Cunha, António Mendes de Almeida, Silvestre Pinheiro Ferreira, Francisco Freire de Carvalho, António da Costa Sousa Macedo, Lopes de Mendonça

Formato: $15,5 \times 22,3 \mathrm{~cm}$

Periodicidade: Quinzenal

Preço: Assinatura - 12 nos - 720 réis $\bullet$ Avulso - 80 réis

Páginas: 396
Cotas:

BN: J.408B.; P.P. 10103 V; P.P. $10248 \mathrm{~V}$. BGUC: 1-(24)-39-1764; O.S. $966-968$ BPMP: P/B/2333

BMC: GHC -1

\section{Objectivo}

«Demonstrar a utilidade das ciências e das letras fora hoje um anacronismo. O nosso século veio marcado com um selo de luz, aonde estava gravada a palavra-civilização; e que as ciências e as letras só a podem conseguir, já não é só uma verdade escolástica, é um facto para todos e para tudo.

A civilização tem sido o grande porto para onde se navega desde o primeiro dia do universo, e para onde se navegará até ao derradeiro...

A imprensa edifica em um dia o que, sem ela, fora sobeja obra para um século... Mas a imprensa dos nossos dias foi a que melhor compreendeu a missão... O nosso século está simbolizado em dois dos seus inventos que ambos se auxi-

(1) Estes nomes encontram-se no apenso ao n. ${ }^{\circ} 8$. 
liam - o vapor e os caminhos de ferro; - é a rapidez e a comodidade: pois também a imprensa só há-de produzir-lhe duas coisas - o livro e o jornal.

Aquele, com toda a sua aristocracia antiga, não passará muito além dos gabinetes e das salas; este, com toda a sua democracia, descerá para a choupana e para a rua, porque o jornal é o livro do povo...

O Panorama era a publicação periódica mais acabada que entre nós se fez... e o Panorama morreu!... Mas Coimbra é a cidade, que em Portugal se chama a cidade das letras; a ciência está aqui no seu trono de rainha...

É a posição que nos tentou, talvez o pejo que nos fez ousados, e, por certo, um desejo íntimo de ir lançar uma pedra no edifício, tão necessário, da instrução pública. Foi uma cruzada de mancebos, que se alevantou cheia de fé viva no coração e de esperança consoladora nos nomes ilustres de alguns dos nossos maiores homens, que lhes prometeram auxílio...

Se o Panorama morreu..., a Revista Universal aí está para nos ser farol...

Era este talvez o lugar próprio para as promessas... não prometemos nada, seremos o que formos, e o futuro que nos julge» (n. ${ }^{\circ} 1,15$ de Março de 1845, p.p. 1-3).

\section{Conteúdo}

Revista Académica é uma publicação que se insere naquele tipo de imprensa que se classifica de jornalismo científico e literário. Reconhecendo a importância e o papel que cabe a uma boa imprensa que «é derramar a instrução entre muitas pessoas, que somente deste modo a podem obter» (Revista Académica, n. ${ }^{\circ}$ 13, p. 197, col. 2) e tomando como exemplo a Revista Universal os seus responsáveis apostam na divulgação de muitas e variadas matérias, procurando, assim, contribuir para o desenvolvimento da instrução em Portugal e, de uma maneira mais particular, para uma ilustração e enriquecimento cultural dos seus leitores, nomeadamente os mais desfavorecidos.

A colecção completa deste periódico é de 25 números, todos com o mesmo formato e número de páginas, excepto o último número, que conta, apenas com doze, formando-se assim um volume de 396 páginas. Para além destas, de referir ainda que, anexo ao n. ${ }^{\circ} 8$, existe um apenso de 4 páginas, onde a redacção da revista presta esclarecimentos sobre a natureza do que nela se publica e isto, em virtude de algumas reaç̧ões a um artigo nela publicado da autoria de Macedo Pinto. 
Neste apenso anuncia-se, também, que uma primeira série terminará com o n. ${ }^{\circ} 12$, mas que a publicação irá continuar com a mesma periodicidade quinzenal. No entanto, a partir do n. ${ }^{\circ} 15$, deixa de haver indicação de datas - dia e mês. Os diferentes números identificam-se através da numeração inscrita no canto inferior esquerdo.

Como já referimos, são múltiplas as temáticas abordadas, abrangendo, assim, várias áreas e domínios do saber. Uma das áreas mais privilegiadas diz respeito às letras e às artes, sobretudo ao teatro. Não admira que assim seja, uma vez que os responsáveis pela publicação decidiram atribuir oito páginas, em cada número, ao Instituto Dramático, que podem ser preenchidas ou não, para que nelas os seus membros apresentassem, não só os seus trabalhos literários, mas também artigos outros, que uma comissão nomeada por aquele Instituto aprovava. Marcando a diferença de autores, em termos formais, assim se explicam as iniciais I.D. (Instituto Dramático), que antecedem os títulos de alguns artigos (Cfr. Revista Académica, n. ${ }^{\circ}$ 1, Introdução, nota).

No âmbito das letras e para além de uma certa criação literária consubstanciada em textos de poesia e textos em prosa como, por exemplo, «O Livro de Elisa. Fragmentos» e «O Fidalgo e o Poeta», de salientar, também, a apreciação e a crítica literária que se fazem a obras várias, nomeadamente, a O Arco de Sant'Ana de Almeida Garrett e a um folheto intitulado «Le Portugal à la hauteur du siècle», escrito em verso e em francês e publicado no Funchal.

Sobre estética em poesia é Silva Pereira quem nos fala sobre os versos de redondilha maior na literatura portuguesa e espanhola, em «Da antiguidade e beleza dos versos octassílabos».

No âmbito das letras e relacionando estas com a pedagogia é de referir o artigo «Traduções Interlineares». Trata-se de um artigo traduzido do jornal The Quartely Journal of Education, onde se fala de métodos de ensino como instrumentos de aperfeiçoamento literário e se dão a conhecer experiências levadas a cabo, com êxito, na língua latina.

No domínio da literatura estrangeira, uma pequeníssima alusão às literaturas brasileira e espanhola com as poesias «A Devoção pelo Sertanejo» e «O Poema do Cid», respectivamente.

No campo do teatro e para além de apreciações aos dramas Maria Pais Ribeira, de João de Lemos, Frei Luís de Sousa, de Almeida Garrett e A Pobre das Ruínas de José da Silva Mendes Leal Júnior, salientam-se a "Crónica do Instituto Dramático» e «Instituto da Literatura e Arte Dramática», onde se dão 
notícias várias deste organismo e se referenciam as actividades desenvolvidas. Dá-se conta, também, das representações levadas a cabo no Teatro Académico e no Teatro de S. Paulo. Com o título «O novo teatro», João de Lemos, defendendo o teatro português, insurge-se contra o facto de o Teatro Nacional de Lisboa ter feito, em 29 de Outubro de 1845, a sua abertura com uma peça estrangeira de Alexandre Dumas, quando ao palco devia ter subido uma peça de um autor português.

Uma outra área a merecer um destaque especial é a área dos estudos científico-naturais. Embora com uma duração não muito longa, na secção «Revista Científica», dão-se a conhecer, não só inventos e experiências realizadas em Portugal e no estrangeiro, mas também notícias e informações várias sobre o que se tem passado em sociedades científicas estrangeiras, nomeadamente: na Sociedade Real de Londres, Geografia de Londres, Lineana, Geológica de Londres, Botânica, Academia das Ciências de Paris e outras.

De referir, também, artigos e pequenos textos como: "A Religião Cristã e a Filosofia. O Génesis e a Geologia», da autoria de J. F. Macedo Pinto, onde, depois de breves considerações sobre as vantagens do método experimental, discorre, na temática referida, sobre a articulação entre religião e ciência, concluindo que há uma concordância entre as épocas geológicas e os dias do Génesis; "Resumo de prelecções de fisiologia experimental», repartidos por vários números, onde o mesmo Macedo Pinto nos descreve experiências várias que fez e nos fala de aspectos múltiplos do sangue: transfusões, dissolução, coagulação e composição; "Barómetro", onde o seu autor alude, não só à história deste instrumento, mas nos fala, também, sobre as condições que se devem observar, para obter boas leituras; em "A Astronomia», L. Albano tece, em primeiro lugar, considerações sobre a ciência em geral, para, depois, nos falar da história da astronomia.

Em pequenos textos como «Mr. Thilorier», dá-se conta da morte deste cientista, mas sobretudo do seu contributo na ciência física; situação idêntica em «Novos trabalhos de M. Milne Edwards».

Apostando na ciência, defende-se e estimula-se a investigação e o espírito científico, ao mesmo tempo que se combate a superstição e a ignorância. No artigo intitulado «O banho santo» critica-se a ignorância do povo, mas sobretudo o clero que alimenta a crença de que as águas de um poço, algures perto de Senhorim, curam enfermidades. Às crenças e superstições antepõem os responsáveis pela publicação os resultados «... das observações meteorológicas feitas 
no Gabinete de Física de Coimbra em 1845", bem como os dados que foram observados e relatados em "Aparição de um cometa».

Outra área a merecer algum relevo nesta publicação é a que se refere à educação e ao ensino. Embora não esteja assinada, mas que sabemos ser de António da Costa de Sousa Macedo ${ }^{(2)}$, aqui se publica, repartida por vários números, uma «Memória histórica sobre a instrução primária entre nós», onde o seu autor nos dá uma visão global do que foi este ramo do ensino, desde o século XXVI até 1845.

Fala-se, também, do Conselho Superior de Instrução Pública - sua história e composição e publica-se um relatório deste órgão, onde, para além de outras dimensões, nos informa sobre «o estado actual do ensino e educação pública entre nós, o quadro de seus principais estabelecimentos, progressivos melhoramentos destes e reformas de que ainda precisam» (Idem, n. ${ }^{\circ}$ 16, p. 241, col. 1).

Ao nível do ensino superior uma palavra muito especial para a Universidade de Coimbra. Em números vários, fala-se desta instituição: alude-se um pouco à sua história; à reforma de 1537; prestam-se informações sobre a organização actual da Universidade e a estrutura dos seus estudos. Reconhecendo-se a falta de uma publicação periódica, onde se dê conta do movimento da Universidade, publica-se o mapa desse movimento relativo ao ano lectivo de 1844 - 45 bem como a relação dos estudantes premiados.

No âmbito do ensino é de referir, também, o texto «Estatística médica de Paris». Aqui se colhem elementos sobre o ensino e o exercício das ciências médicas naquela cidade francesa.

Sabendo-se da importância que o saber tem, sobretudo ao nível das classes menos favorecidas como os agricultores, defende-se que para estes haja uma instrução própria e adequada, de carácter mais utilitário, onde se ensinem «os preceitos mais úteis e as práticas mais vantajosas da agricultura» (Idem, n. ${ }^{\circ}$, p. 306 44, col. 1).

Reconhece-se que nesta instrução popular cabe à imprensa, sobretudo aos jornais científicos e literários, um papel muito importante. Citando estatísticas de países europeus, faz-se a defesa deste tipo de imprensa em artigos como: «Jornalismo Literário» e «Os jornais literários francos de porte». Daí também o

(2) Cfr. Joaquim Ferreira Gomes, Estudos de História e de Pedagogia, Coimbra, Livraria Almedina, 1984, p. 108, nota 1. 
entusiasmo com que nesta matéria saúdam e defendem o aparecimento, na ilha de S. Miguel, nos Açores, do jornal O Agricultor Michaelense, o qual mereceu um artigo intitulado mesmo «O Agricultor Michaelense».

Depois de algumas considerações sobre a agricultura, aqui se recomenda que se «ensine por toda a parte os melhoramentos úteis, para que todos possam aproveitar-se deles» (Idem, n. ${ }^{\circ}$ 25, p. 389, col. 2) e se apela à criação e organização de sociedades de lavradores, como acontece no estrangeiro.

Ao nível da indústria, o mesmo com o periódico O Industrial Portuense.

Outro domínio do saber a ocupar um lugar de destaque é a História. No contexto da história francesa, é António de Serpa Pimentel quem reflecte sobre a vida e a obra de Louís Blanc, no artigo «O historiador Louis Blanc».

No âmbito da história portuguesa são de salientar os seguintes artigos: «Antiguidades Portuguesas. Etimologia de nome Lusitânia», onde se fala da história da Lusitânia, da origem do seu nome e das origens de Portugal; com o título de «História de Portugal durante a Idade Média. Fragmentos», publicam-se alguns extractos da História de Portugal de Alexandre Herculano; «Memória Histórica sobre o intentado descobrimento de uma suposta ilha ao norte da Terceira». Trata-se de uma memória de autoria de Sena Freitas, que foi publicada na Revista Universal, e que na apreciação que lhe é feita se diz que esta memória vale «pelas notícias curiosas e importantes descobertas de factos, que jaziam sepultados no esquecimento» (Idem, n. ${ }^{\circ}$ 16, p. 256, col. 1); finalmente, repartida por vários números, uma «Bibliografia abreviada da História de Portugal», onde se dão a conhecer contributos que várias personalidades dão para o estudo da nossa história.

E, porque as questões de moral e justiça são importantes, elas têm também o seu lugar. No artigo «Influência do cristianismo sobre a legislação» procurase demonstrar, no contexto do cristianismo, como a ideia religiosa, que é a ideia maior e mais arreigada no coração dos povos, se reflecte no direito desses mesmos povos.

No artigo «Do Sistema Penitenciário», também António Mendes de Almeida e Silvestre Pinheiro Ferreira reflectem sobre a organização das nossas cadeias e sobre questões da nossa justiça, apontando algumas soluções e bases de reforma.

Também em «Cadeia Académica» se denunciam as más condições do forte do Aljube, que serve de prisão académica, enquanto não estiver pronta a da Universidade. 


\section{3 • REVISTA ACADÉMICA}

Publicação mensal, literária e científica

Coimbra, Imprensa de E. Trovão

Dezembro 1853 - Novembro 1854

Redactor: Alexandre Meireles

Colaboradores: J. G. de Barros e Cunha, F. Soares Franco Júnior, Ernesto Marecos, Tomás Ribeiro, A. Aires, Gaspar de Queirós, J. de Lemos, Vicente da Silveira, A. A. Geraldes, J. A. Santos e Silva, A. J. Teixeira, Augusto Filipe Simões, José Teixeira de Queirós, José Joaquim de Azevedo, João de Deus, Manuel Alves Guerra, J. C. A. de Medeiros, N. C. Pita e Sebastião José de Carvalho

Formato: $18 \times 27,5 \mathrm{~cm}$

Periodicidade: Mensal

Preço: Não indica

Páginas: 272

\section{Cotas:}

BN: J.327// 22 P; J.965//40 P.; P.P. 3427 A.

BGUC: $10-7-14-6$

BPMP: P/B/2333

BMC: GHC -1

\section{Objectivo}

«Ainda não há muitos anos, que uma robusta e briosa geração académica cruzava, ébria de prazer e contentamento, as ruas de Coimbra, lendo, escrevendo, publicando peças de eloquência e de poesia, que fariam inveja aos mais famosos literatos da época, e passeando ao longo das margens do Mondego, ora curtindo saudades da pátria, ora bebendo na sua suave melancolia de suas cristalinas águas as torrentes de poesia, com que depois inundava os prelos da

308 Revista Académica. E longe não vai também a época, em que o Teatro Académico parecia vergar debaixo do peso das coroas, com que os filhos de Minerva costumam adornar as frontes dos predilectos das musas...

Que é feito desses mancebos, cujo peito batia sempre ao pronunciar os doces nomes de amor e liberdade?

... Seus nomes ficaram ... registados nas páginas gloriosas da literatura daquele tempo...

Mas deixaram-nos um legado precioso, uma herança gloriosa, um nome sagrado pela imortalidade: deixaram-nos a Revista Académica... 
Aí vem pois sentar-se de novo nos arraiais da imprensa a Revista Académica; vem religiosamente cumprir a sua missão no mundo literário; se lhe minguarem as forças, se lhe falecer o engenho, não lhe hão-de faltar, querendo Deus, nem a fé que vivifica, nem a esperança que regenera...

É escusado dizer que as colunas da Revista Académica tornam a ser abertas franca e lealmente para todos os amigos das letras, académicos e não académicos, talentos ainda em gérmen, e engenhos já floridos e provados nas batalhas da inteligência: a Revista, surgindo das ruínas do passado, não faz mais do que levantar um pendão simpático à mocidade e à pátria, que exulta sempre em ver reunida em roda dele a flor de seus filhos os mais caros.

A Revista discutirá sempre pacífica e lealmente, e o seu verbo será o da sua antiga irmã-justiça para todos, e amor e compaixão para esta terra, que hoje, mais do que nunca, há mister de todos os esforços da inteligência, de todos os recursos do coração, para um dia tomar o lugar que lhe compete no grande banquete das nações, que marcham na vanguarda da civilização» (Revista Académica, n. ${ }^{\circ}$ 1, Dezembro de 1853, p.p. 1-2).

\section{Conteúdo}

Inspirada em revista anterior com o mesmo nome (Revista Académica, 1845), que recorda e evoca, esta nova publicação, aberta a estudantes e não estudantes, trata de questões múltiplas, que abrangem problemáticas várias e domínios diversos do saber, contribuindo assim para um enriquecimento dos leitores e do país.

A colecção completa desta publicação consta de doze números, todos com o mesmo formato e número de páginas - 20. De referir, relativamente ao último número, a existência ainda de um suplemento com 32 páginas, onde se publicam um trabalho de Matemática, da responsabilidade de J. C. Medeiros, poesia, se fala da Sociedade Filantrópico-Académica, se dá conta da exortação que fez aos seus alunos o professor da $3^{\text {a }}$ Cadeira do Liceu Nacional de Angra do Heroísmo, no ano de 1847, e «Manuscrito vindo de Santa Helena», de Vicente da Silveira, cuja publicação teve início em números anteriores.

A componente literária desta publicação traduz-se em textos em prosa e verso como, por exemplo, «Páginas de vida íntima», de Alexandre Meireles e de poesias várias, incluindo aqui algumas em língua francesa. Artigos também no 
domínio da literatura portuguesa e estrangeira como «Vida de Luís de Camões», repartido por três números, e "Reflexões sobre o teatro alemão», onde Manuel Alves Guerra reflecte sobre a matéria e faz uma apreciação a alguns trabalhos de Schiller.

À semelhança do que acontece em outras publicações, a temática ligada ao teatro tem, aqui, um pequeno espaço, na medida em que se reconhece que «o teatro, indubitavelmente, é o prazer predilecto de Coimbra... Os bailes, concertos, soirées, qualquer festa enfim, são excepções da vida pautada e regrada da cidade» (n. ${ }^{\circ}$, p. 117, col. 2). Daí a existência de dois textos intitulados «Teatro Académico", onde se dá conta, não só das representações aqui levadas a cabo, mas também das respectivas apreciações críticas.

Ainda no domínio da literatura, uma palavra especial para a temática da literatura de viagens, num texto do mesmo Alves Guerra e intitulado «Uma Viagem ao Faial».

Uma das temáticas abordadas nesta revista é a questão social. Logo no primeiro número, Santos e Silva, no artigo «Associação», reflecte sobre algumas das escolas onde se discute a natureza, origem e leis da sociedade, para concluir da importância que têm o princípio do associativismo, que ninguém ainda renegou, e a instauração de uma democracia social. Se, no dizer de Alexandre Meireles, «o homem isolado seria um aborto da natureza, uma degradação da espécie» (n. ${ }^{\circ}$ 5, p. 97, col. 1), se aquele princípio «é a bandeira conciliadora, que fraterniza o interesse individual com o geral» (n. ${ }^{\circ}$ 1, p. 5, col. 2), a democracia social» quer que se garanta o sustento ao proletário; quer trabalho, instrução, e moralidade para todos; quer a extinção do pauperismo; quer a emancipação industrial; quer que acabe a exploração do homem pelo homem» (Idem, p. 5, col. 2 e p. 6, col. 1).

Ainda a propósito desta questão é Leandro José da Costa Júnior quem, no artigo intitulado «Socialismo», procura dar a conhecer os grandes princípios em que este sistema assenta. Fá-lo, porque reconhece tratar-se, não só de «uma matéria de tanta importância e de tamanho vulto» (n. ${ }^{\circ}$ 5, p. 86, col. 1), mas também de «um sistema realizável» (Idem, col. 2), ao contrário do comunismo, cujos princípios «são revoltantes, por serem exclusivos» (Ibidem).

Outra das questões tem a ver com educação e ensino. É A. A. Geraldes quem, no artigo «Instrução Pública», tece algumas considerações gerais sobre a matéria, para, depois, falar dos liceus e do estudo das Ciências Naturais. 
Também Manuel Alves Guerra se debruça sobre o ensino particular, em três artigos intitulados "Os Colégios de Educação». Depois de se apontarem alguns defeitos na organização, métodos, regulamentos e selecção de pessoal, nomeadamente de professores devidamente habilitados, conclui-se da necessidade de uma intervenção, a qual compete ao Estado, na medida em que «todo o colégio deve ter uma lei, uns estatutos que o regulem, e sirvam de garantia ás pessoas que lhe confiam a educação dos seus filhos» (n. ${ }^{\circ}$ 7, p. 138, col. 2).

No domínio da educação e ensino, algumas reflexões, também, sobre a problemática da instrução primária, nos Açores. Se José Joaquim de Azevedo, em «Aos Açoreanos Ocidentais», tece algumas considerações sobre aspectos vários da vida nos Açores e defende a criação de escolas de instrução primária no arquipélago, é, sobretudo, no artigo «Instrução Primária. Selectazinha clássica para uso das escolas do distrito de Angra» (Cfr. n. ${ }^{\circ} 9$, Agosto de 1854), que se fazem reflexões e se identificam alguns problemas deste nível de ensino.

Ainda num contexto educativo, $\mathrm{o}$ artigo «A infância e mocidade dos grandes homens", onde se procura mostrar aos leitores que os homens que conquistaram a imortalidade, neste mundo, «haviam preparado pela sua conduta e carácter, pelas tendências do seu coração, e pela direcção de sua educação, o papel que depois vieram a desempenhar» (n. ${ }^{\circ} 6$, p. 119, col. 1), como foi o caso de Benjamin Franklin, de que nos fala este artigo.

Sociedade e Economia é outro dos assuntos em estudo, nos artigos «Liberdade de Comércio» e "Do crédito e dos bancos», da responsabilidade de Sebastião José de Carvalho e José Teixeira de Queirós, respectivamente.

De salientar, neste âmbito ainda, as reflexões que Alexandre Meireles faz no seu artigo "Vias de Comunicação» (Cfr. n. ${ }^{\circ} 7$, Junho de 1854). Depois de referir a importância da matéria e de uma breve alusão às finanças públicas, procura, citando exemplos, evidenciar as vantagens que os transportes podem ter na sociedade e na riqueza nacional.

No âmbito da História, há a salientar o artigo, repartido por quatro números, e intitulado «Testamento Político de D. Luís da Cunha» e de A. J. Teixeira, «Tipos Populares», com um estudo sobre a figura da «regateira da praça».

Ainda no domínio de História e para uma história da Sociedade Filantrópico - Académica colhem-se aqui, também, alguns elementos importantes. Para além do «discurso proferido na sessão solene... pelo delegado Alexandre Meireles de Canto e Castro» e dos relatórios de contas (Cfr. n. ${ }^{\text {os }} 4$ e 5), em 
«Correspondência», apontam-se medidas tomadas para melhorar a Sociedade e dão-se informações várias sobre a mesma.

Também no domínio da medicina e biologia, há a salientar o artigo «Fisiologia» de J. A. Santos e Silva e «Dissertação Fisiológica», onde se reflecte sobre a questão da hematose e se apresentam teorias explicativas do fenómeno.

De salientar, finalmente, os artigos de N. C. Pita, «Influências do clima em geral», de Augusto Filipe Simões sobre «Raças Humanas» e de A. A. Geraldes, «Aerostação», a propósito da navegação aérea. 


\section{4 • REVISTA GIENTÍFICA E LITERÁRIA}

Coimbra, Imprensa Académica

Dezembro 1880 - Fevereiro 1881

Directores: António Feijó e Luís de Magalhães

Colaboradores: Manuel Emídio Garcia, Correia Barata, Augusto Rocha, Aristides da Mota, Luís Woodhouse, Carlos Lobo de Ávila, João Pinto dos Santos, Henriques da Silva, Silva Gaio, Luís

Osório, A. Rodrigues Braga, Eduardo de Araújo, Pedro de Mascarenhas, Alfredo Paço Vieira, Miguel Baptista da Silva, António Pinto de Mesquita, Leopoldo Mourão

Formato: $15,5 \times 22,5 \mathrm{~cm}$

Periodicidade: Mensal

Preço: 100 réis

Páginas: 96
Cotas:

BN: J. 334//13 P. BGUC: 9 - (3) - 20 - 9 BPMP: -

BMC: GHC $-19 / 6$

\section{Objectivo}

«A mais poderosa causa do estacionamento das civilizações e da morte das nacionalidades é - como a história no-lo demonstra - a falta de actividade mental. Toda a prosperidade política, económica, moral ou civil de um povo está na razão directa do seu avanço científico e literário. Enquanto uma nação sentir vigoroso o poder da inteligência colectiva, essa nação não morre; mas, se uma causa qualquer lhe atrofiar a força impelente e directora das grandes ideias, não tardará muito que o seu nome seja uma simples recordação na história...

Portugal apresenta este mórbido sintoma, triste e desolador...

Renasceremos?

Extinguir-nos-emos, mais ou menos proximamente, pela debilidade da nossa organização?

Eis o problema fatal que é preciso resolver...

Os redactores desta revista não presumem que vão salvar a pátria com os seus escritos... Criando a Revista Científica e Literária não temos em vista outro fim que não seja o de tornarmos pública uma certa actividade mental, que nos pareceu desaproveitada e estéril pela falta de um campo próprio em que se trabalhasse livremente. 
Depois da Folha as gerações académicas nunca mais tiveram um orgão de trabalho literário, regular e perdurável...

Alargar indefinidamente o âmbito dos assuntos, abrir um campo de publicação não só às manifestações da Arte, mas também às da Ciência, eis o espírito da nossa Revista...» (Revista Científica e Literária, n. ${ }^{\circ}$ 1, Dezembro de 1880, p.p. 1-3).

\section{Conteúdo}

Inserida no contexto do movimento positivista, esta revista procura, conforme propósitos enunciados pelos seus responsáveis, divulgar o maior número de temas possíveis, para ilustração dos cidadãos.

Reconhecendo os directores desta publicação que a sua época «caracterizase pelo enciclopedismo, pela solidariedade das ciências realizada na vasta síntese hierárquica da classificação comteana» (Idem, n. ${ }^{\circ}$ 3, p. 83), o grande tema que domina nesta revista é a defesa e afirmação da ciência como o grande guião da Humanidade, porque, ao prever, permite agir.

Num desdobramento temático mais estreito é possível identificar questões como:

- Fé e Ciência

- Literatura, Arte e Ciência

- Economia e Ciência

- A necessidade de uma nova educação e instrução em Portugal à luz da nova realidade - a instrução secundária. Ainda no contexto da educação positivista veja-se o conto intitulado «Os Pós d'Arroz» da autoria de Luís de Magalhães

Completam esta revista algumas poesias e a secção de "Bibliografia», onde se faz uma apreciação crítica aos livros de Oliveira Martins, Portugal Contemporâneo e Elementos de Antropologia. 


\section{5 • REVISTA DO GIVIL (1)}

Coimbra

1899
Cotas:

$\mathrm{BN}$ : -

BGUC: -

BPMP: -

BMC: -

(1) Segundo Carneiro da Silva, esta revista deve-se à iniciativa de Alberto Costa, mais conhecido por Pad-Zé. Trata-se de uma revista de troça e de crítica de que saíram dois números, em 8 e 15 de Março de 1899. (Cfr. Ob. cit., p. 117). Não conseguimos encontrar nenhum exemplar desta publicação. 


\title{
116 • REVISTA COIMBRÃ
}

\author{
Publicação Quinzenal \\ Cotas: \\ Coimbra, Tip. Reis Leitão \\ 16 Novembro 1899 - 16 Março 1900 \\ BN: J. 451//6 M. \\ BGUC: - \\ BPMP: - \\ BMC: GHC -2
}

\author{
Editor: Francisco Borges \\ Colaboradores: Lourenço de Almeida Medeiros, José \\ Bruno Carreiro, Teixeira de Pascoais, A. A. Pires \\ de Lima, José Castanho, Ferreira Sucena, Maga- \\ lhães da Silva, Francisco Alexandrino, Domingos \\ Pepulim, João de Deus Ramos, Francisco de \\ Ataíde Faria e Maia, António de Noronha, M. \\ Fernandes Laranjeira, João Lúcio, J. Costa, João \\ de Barros, Alfredo Pimenta, Augusto de Castro, \\ Pinheiro Guimarães, José Emídio Soares da Costa \\ Cabral, Ramos Paiva e Bernardo Madureira \\ Formato: $17,5 \times 24,5 \mathrm{~cm}$ \\ Periodicidade: Quinzenal \\ Preço: Seis números -300 réis • Avulso -50 réis \\ Páginas: 96
}

\section{Objectivo}

«Eis, com toda a singeleza, o nosso fim: facultar a expansão livre de várias actividades intelectuais, unindo-as apenas por um laço único - a Revista Coimbrã.

A ninguém se fecham as suas colunas, a ninguém se impõe orientação algu316 ma.

O Bem, o Belo, a Verdade podem ser encarados sob qualquer aspecto ou revestir, qualquer forma.

Como corolário, nem mesmo uma crítica severa entre colaboradores originará a mínima incompatibilidade.

Não. Iniciadores desta revista, aceitamos como dogma a liberdade de pensamento, a liberdade de expressão.

Somente assim - cremos nós - brotará natural, espontâneo, o fruto de cada aptidão, o palpitar de cada temperamento» (n. ${ }^{\circ} 1$, p. 1). 


\section{Conteúdo}

Trata-se de uma pequena revista, aberta a todos, sem restrições, e cujo objectivo fundamental é, não só divulgar cultura, mas também contribuir para o desenvolvimento de toda e qualquer actividade intelectual.

A colecção completa desta revista é de seis números, todos com o mesmo formato e número de páginas.

Aberta a toda a actividade intelectual, para além de uma certa produção literária, em textos em prosa e verso, aqui se tratam diversos assuntos como os que a seguir se indicam:

- Teatro - Com o título de «Teatro Académico e a récita de 1901», Magalhães da Silva e António de Noronha, em posições divergentes, reflectem sobre concepções e problemas vários do teatro e sobre o tipo de teatro que se faz ou devia fazer em Coimbra.

- No domínio da Sociologia, A. A. Pires de Lima, fala-nos não só da problemática dos fenómenos sociais e de sua sistematização, no artigo intitulado «Ensaio de classificação sistemática dos fenómenos sociais», mas também do Estado que ele entende não ser um organismo, mas apenas «uma entidade que se coloca acima da sociedade natural, e se propõe educá-la e dirigi-la» (n. ${ }^{\circ}$ 5, p. 69, col. 1).

- A guerra, os interesses das grandes potências e o direito. Reportando-se ao conflito entre a Inglaterra e o Transval, é Ferreira Sucena quem, no artigo intitulado «A Guerra», reflecte sobre aquela problemática, para concluir que «nem sempre o triunfo do número é a vitória da razão» (n. ${ }^{\circ}$ 1, p. 9, col. 2).

- Sociedade e sentimentos afectivos. Citando A. Comte, Michelet e outros é António de Noronha quem no estudo intitulado «Amor. Casamento. Divórcio. Amor Livre», procura relacionar aqueles com a evolução da sociedade e da civilização. Invocando o instinto de reprodução, fala-nos da mulher, da noção de posteridade, de razões de utilidade, de fraternidade, de monogamia e de poligamia, para, por fim, fazer algumas reflexões sobre a sociedade industrial. 
- O jogo e seus problemas. É Ferreira Sucena quem, no artigo «O Jogo» reflecte sobre esta problemática. Em sua opinião, o jogo é «uma das calamidades que mais corrompe uma sociedade» (n. ${ }^{\circ} 4$, p. 54, col. 1). Aponta, depois, algumas consequências funestas que resultam da prática do jogo.

- Academia e espírito académico. No artigo «Vida Nova», Magalhães e Silva tece algumas considerações sobre o que tem sido o espírito académico, em Coimbra. De há muito que este espírito se resume a «uma trindade malditajogo, bebidas e amores» (n. ${ }^{\circ} 6$, p. 86, col. 1) e as lutas políticas não passam «de um amontoar de ódios violentos» (Idem), quando deviam ser um conjunto saudável e nobre de ideias. Graças à Associação Académica e ao Teatro Académico há, todavia, uma esperança de mudança.

- Ciência e desenvolvimento científico. É Lourenço de Almeida Medeiros quem, em «A atracção universal», nos fala de Newton e das leis do movimento, citando, também, sobre o assunto, pensadores gregos.

Para além destas questões mais centrais, a existência, de textos de índole histórica e cultural como «Irrupção dos bárbaros no Norte no Império Romano do Ocidente», de Pinheiro Guimarães, e «As formas representativas e as raças latinas», de Lourenço de Almeida Medeiros, onde se alude à relação entre as raças e formas políticas, citando exemplos da história.

De referir, finalmente, a secção de «Bibliografia», onde se dá conta das publicações recebidas. De assinalar, também, o sentido de solidariedade que esta revista teve para com a Assistência Nacional aos Tuberculosos, franqueando-lhe as suas colunas.

- Transcreve-se, também, um artigo já publicado no Correio Nacional, de 318 Lisboa, da autoria do Prof. Bernardo Madureira, na passagem do $30^{\circ}$ dia do falecimento do Prof. Júlio Sacadura, da Faculdade de Medicina. 


\section{7 • REVISTA DE COIMBRA}

Folha Bimensal

Coimbra, Imprensa Literária

1 Dezembro 1865 - 15 Abril 1866
Cotas:

BN: J.239//4B.;J.317//1P.; BGUC: J.1386B.;PP.11796V.

BPMP: -

BMC: GHC $-19 / 6$

Director: F. Guimarães Fonseca

Colaboradores: António Maria Seabra de Albuquerque, Aleixo dos Santos, Álvaro de Carvalho, Antero de Quental, João de Deus, M. A. Álvares de Azevedo, Joaquim Vale, João Penha, Luís Jardim e Teófilo Braga

Formato: 18,5 x $27 \mathrm{~cm}$

Periodicidade: Bimensal

Preço: Trimestre -300 réis

Páginas: 72

\section{Objectivo}

«Não tentamos inaugurar um periódico de debates escolares, e fazemos desde já esta declaração, para que se não julgue que vamos entrar em polémica fastidiosa com um ou outro escritor, cujas obras, por ventura, incitassem animadversão da parte dos seus colegas nos trabalhos literários: não visa a tão alto escopo esta humílima publicação. Queremos somente aligeirar as horas de mais sérios estudos.

Houve quase sempre entre nós uma folha literária, quase sempre exclusivamente literária, em que escrevíamos as impressões agradáveis da mocidade, os deliciosos sonhos de nossas almas... e foi sempre assim que se formou a literatura de Coimbra, singela, desataviada de postiças galas dos velhos sábios, moça no colorido e no sangue, alegre e entusiasta, cismadora, por vezes, porque no meio das flores da sua várzea esplêndida olhava também para o céu do futuro...

Pouco importa: escreveremos tudo o que julgarmos bom e útil, sem nos embrenharmos nas estéreis discussões de princípios particulares, que por serem património de um homem notável, ou de uma escola ilustre, nem por isso poderão servir de norma absoluta a quem sonha entre os vergeis da imaginação com as rosas do céu. 
Publica-se esta folha para nos distrairmos das graves lucubrações da ciência; não fazemos com isto mais nada, do que empregar bem o tempo de descanso. Este periódico é para todos os que no silêncio do seu quarto, antes de abrirem os livros, querem voejar entre os jardins da imaginação a delibar o néctar dos deuses e mostrar depois o sentimento suavíssimo das suas almas» (n. ${ }^{\circ} 1$, p. 1).

\section{Conteúdo}

Revista de Coimbra é um espaço de produção e criação, fundamentalmente, literária, visando, como referem os seus responsáveis, dar lugar à imaginação, no sentido de amenizar os intervalos do estudo e de ocupar as horas de lazer.

Compõe-se esta colecção de nove números, todos com o mesmo formato e número de páginas.

Porque de carácter literário, dominam esta revista um conjunto de textos, em prosa e verso, de que salientamos, entre outros, «História de Madalena», o conto intitulado «A estátua viva», poesias várias e «Tanoedo», que é um poema herói-cómico.

A par da prosa e do verso, a existência, também, no domínio da literatura, de dois artigos: «Romance do ciclo greco-romano na poesia popular portuguesa», de Teófilo Braga, e «Da importância da poesia. Manifestada nos primeiros tempos da Grécia e pelos trovadores da Idade Média», da autoria de Aleixo dos Santos. Depois de uma incursão pela história da Grécia e de breves considerações sobre a Idade Média, aqui se reconhece e afirma que «um bom poema é... o meio mais eficaz que se conhece para animar o espírito» (n. ${ }^{\circ} 4$, p. 25, col. 1).

No âmbito da história regional, de salientar o artigo alusivo à heráldica da cidade de Coimbra, da responsabilidade de Seabra de Albuquerque com o título de «Considerações sobre o brasão da cidade de Coimbra».

De referir ainda um conjunto de reflexões sobre o estado da Europa, suas tendências, interesses e contradições da autoria de Luís Jardim, em «Estudos políticos e sociais».

Completa-se esta revista com a secção permanente de «Crónica», onde, a par de uma parte noticiosa, se fala, também, de teatro e questões literárias. 


\section{8 - REVISTA GONTEMPORÂNEA}

De Questões Religiosas, científicas, filosóficas, históricas e sociais

Coimbra, Imprensa Académica

Outubro 1894 - Dezembro 1896
Cotas:

BN: L. $7261 / / 5 \mathrm{~V}$

BGUC: $10-5-9$

BPMP: -

BMC: GHC -2

Director: Fortunato de Almeida

Administrador: José Marques Rito da Cunha

Redactores: Luís Maria da Silva Ramos e Fortunato de Almeida

Colaboradores: A. Gonçalves, Lopo José de Figueiredo Carvalho, José Maria Antunes, Ernesto de Vasconcelos, Luciano Cordeiro

Formato: $15,5 \times 22,5 \mathrm{~cm}$

Periodicidade: Mensal

Preço: $1 \$ 600$ réis anuais

Páginas: $1 .^{\circ}$ Vol. $-392 \bullet 2 .^{\circ}$ Vol. -412

\section{Objectivo}

«Examinar os grandes problemas sociais que agitam o mundo civilizado, discutir as questões científicas de mais viva actualidade, e estudar, à luz de uma crítica justa e esclarecida, os assuntos históricos de maior interesse, - tal é o ideal e o programa da Revista Contemporânea. Para orientação dos nossos trabalhos tomaremos como guia seguro e infalível o critério da filosofia cristã, que foi em todos os tempos, e continuará a ser no futuro, um elemento indispensável para o esplendor das ciências e para o bem-estar das sociedades...

É um facto incontestável que, com a pregação do cristianismo, ficou estabelecida sobre a terra uma nova ordem de ideias, de costumes e de instituições...

Damos de barato, admitimos até, - que não vai nisso nada que ofenda a pureza do dogma cristão —, que o cristianismo está também sujeito à grande lei da evolução... Não é uma crença estacionária, como alguns afirmam sem a conhecerem, mas uma crença sempre antiga, porque é imutável por verdadeira, e sempre nova, porque acompanha o progresso dos conhecimentos humanos e deles recebe novos argumentos para confirmação de que é verdadeira... 
É uma verdade indiscutível, e já vai calando felizmente no espírito de muitos incrédulos, que o socialismo e o anarquismo são uma consequência necessária da legislação e da política anti-cristã dos estados modernos... É necessário voltar aos princípios cristãos, é necessário informar a legislação com estes princípios salvadores, é necessário, numa palavra, que Jesus Cristo reine e governe nas sociedades, para que estas não pereçam nos abismos da anarquia.

Estas são também as verdades que o grande Pontífice Leão XIII tem proclamado ao mundo nas suas imortais Encíclicas, e nomeadamente na Encíclica Rerum Novarum sobre a condição dos operários, que está destinada a operar no seio desta sociedade enferma uma transformação salutar.

Seguindo os ensinamentos de Leão XIII, a quem desde já promete obediência incondicional, a Revista Contemporânea dedicar-se-á muito particularmente ao estudo das questões sociais...

Não é, porém, só a sociologia moderna que combate o dogma católico; combatem-no igualmente a filosofia e a ciência das escolas que prescindem da fé, e por último a história que, nas mãos de certos escritores, é, como disse José de Maistre, uma vasta conspiração contra a verdade.

A Revista Contemporânea, no intuito de bem servir a Igreja e a causa da verdadeira civilização, não pode, pois, abandonar o estudo das questões filosóficas, científicas e históricas.

O nosso desejo é tornar a Revista Contemporânea útil e proveitosa à causa tão brilhantemente sustentada por Leão XIII...

Contamos com o auxílio de todos os homens de boa vontade que se interessam no triunfo desta causa nobilíssima, e, protestando a nossa rendida obediência a todos os mandatos da Cadeira Apostólica, encetamos a nossa missão simultaneamente católica e patriótica» (Revista Contemporânea, Vol. I, Coimbra, Imprensa Académica, 1894-1895, p.p. 1- 6).

\section{Conteúdo}

Trata-se de uma revista de cariz cristão e católico, com «obediência incondicional» a Leão XIII. São propósitos desta publicação servir, não só a igreja, mas também a causa da verdadeira civilização, a qual, no entender dos seus responsáveis, se identifica, não tanto com os novos tempos e as novas conquistas, mas com o pensamento e doutrina da igreja, numa palavra, com a civilização cristã, 
sustentada e defendida por Leão XIII. Daí que, para além da publicação de documentos emanados da Santa Sé, se afirme, nos diversos assuntos tratados, uma perspectiva de dimensão cristã e católica. A reforçar este sentido transcrevem-se, também, artigos, notícias e documentos, já publicados em outros periódicos, como, por exemplo, na Revue Bénédictine da Bélgica, em Novidades e no Correio Nacional.

A colecção completa desta revista é de vinte e quatro números, a que se juntam mais quatro suplementos, todos com o mesmo formato, constituindo dois grossos volumes, que abrangem um total de 804 páginas, com os índices. Todos os números desta revista têm 32 páginas, excepto os nos 7 e 12, do vol. II, que ultrapassam aquela margem.

Com uma periodicidade cumprida quase a $100 \%$, o que é muito raro em publicações estudantis, apenas os nos 8 e 9 , do ano II, foram publicados em conjunto.

Incluídos na parte final do Vol. I, os quatro suplementos não têm todos o mesmo número de páginas. Se os suplementos $n^{\text {os }} 1$ e 4 têm, cada um, 8 páginas, já os outros se fixam com 16, cada. Nestes suplementos publicam-se, não só documentos pontifícios, mas também se dão respostas a questões, de natureza diversa, colocadas pelos assinantes. Documentos pontifícios são, igualmente, publicados em outros números da revista.

Constituindo-se como uma fonte importante para a afirmação da civilização cristã, a Revista Contemporânea trata, como o próprio nome sugere, de assuntos que dominam o tempo. Temáticas como o socialismo, o anarquismo e o ateísmo têm, logo nos primeiros números, um lugar de destaque. Apesar de, nos diversos artigos sobre estes temas, nos serem fornecidos elementos importantes sobre os mesmos, a distinção que lhes é conferida não é, todavia, para se fazer a apologia dos seus valores, mas para os denunciar. No que se refere ao socialismo, é Fortunato de Almeida quem, no artigo intitulado «O Socialismo Alemão», depois de nos falar um pouco da história do socialismo em terra germânica, nos diz, recordando a estratégia de Liebknecht, que «a guerra aberta à religião não era bom processo para se conseguir o ideal socialista, e que a escola, o livre pensamento e a propaganda socialista é que se iriam encarregando de destruir os princípios religiosos» (Vol. I, p. 12).

Com o título de "Anarquia» é, também, Fortunato de Almeida, quem, depois de nos referenciar as origens do anarquismo, seus autores, programas e 
congressos e nos falar deste movimento em diversos países da Europa, nos retrata este tipo de sociedade como sendo «o predomínio do mais forte sobre o mais fraco, o assassinato, o roubo, a desgraça da mulher, toda a espécie de violência e de imoralidade» (Idem, p. 34).

O mesmo se passa quando se fala de ateísmo. Falando-nos sobre os estados ateus, Silva Ramos diz-nos que esses estados «governam como se Deus não existisse e legislam contra todos os princípios de justiça e de moralidade cuja origem única é Deus» (p. 15).

Estes mesmos propósitos estão igualmente presentes nas críticas e no repúdio que Fortunato de Almeida faz às teorias colectivistas, nomeadamente a Marx, no artigo "A Questão Social», onde, citando Emílio de Laveleye, conclui que «não é pela crítica das doutrinas económicas... que hão-de curar-se os males da sociedade actual ... (Só) no Evangelho reina em toda a parte uma grande ternura pelos deserdados, ao mesmo tempo que um sentimento sublime de justiça social» (p. 308).

O mesmo intuito, na apreciação crítica que Silva Ramos, no artigo intitulado «A crítica de um socialista», repartido por três números, faz à dissertação que o Dr. Afonso Costa apresentou, na Faculdade de Direito, para acto de Conclusões Magnas, com o título de A Igreja e a questão social. Análise crítica da Encíclica «De Conditione Opificum» de 15 de Maio de 1891, com um apêndice contendo o texto latino e a versão portuguesa da encíclica, e da qual o autor ofereceu um exemplar à Revista Contemporânea. Dadas as muitas incoerências que apresenta, no dizer de Silva Ramos, as contradições são «uma nota característica da Dissertação» (p. 283). Os erros relativos ao cristianismo, à igreja e à história levam-no a classificá-la como sendo um «trabalho infeliz» (p. 281), retirando-lhe assim credibilidade.

No que à fé diz respeito, o sentido da mensagem cristã é igualmente transmitido na desmistificação que o Dr. José Lapponi, médico particular de Leão 324 XIII, fez na conferência que proferiu em Roma, na Academia dos Árcades, em 20 de Fevereiro de 1895, sobre «Os milagres de Lourdes e as objecções dos médicos», e que nesta revista se publica.

O contributo da Igreja para a cultura, ciência e a civilização dos povos é outra das tónicas em evidência, em artigos e textos, de índole diversa, bem como em relatórios e exposições. Em «A missão científica da Igreja», Silva Ramos dá-nos a conhecer os proveitos que diversas personalidades da igreja católica deram nos vários domínios do saber, desde as ciências filosóficas, teológicas e jurídi- 
cas até à eloquência e belas-artes, passando pelas ciências experimentais, ao longo dos tempos; Fortunato de Almeida, em "Missionários portugueses no Brasil», fala-nos sobre o trabalho «ao mesmo tempo... religioso, civilizador e patriótico» (p. 138), que a Companhia de Jesus, nomeadamente os Padres Leonardo Nunes, Manuel da Nóbrega e Luís de Gram desenvolveram no Brasil; «A igreja e as Universidades» é outro artigo onde Silva Ramos, depois de se referir às origens da Universidade, procura demonstrar que, sempre e em todos os tempos, a igreja esteve com o saber e prestou a devida protecção às universidades, recordando, para o efeito, o pensamento de Carlos Magno, que pensava «que a restauração religiosa dependia em grande parte da científica, e para lograr aquela começou por esta» (p. 213). Citando Leão XIII, não deixa, no entanto, de referir que «o golpe mais profundo e mais certeiro que se pode descarregar sobre o cristianismo é certamente a supressão das escolas superiores de ensino religiosos» (p. 212); numa certa crítica que o Dr. Afonso Costa, na sua dissertação já referida, faz às ordens religiosas, acusando-as de ociosidade e de inutilidade, a Revista Contemporânea responde com o texto «Memórias de outro tempo. Os frades e a agricultura». Este texto mais não é que um conjunto de extractos dos escritos de Frei Fortunato de S. Boaventura, onde se procura demonstrar o contributo que a Ordem de Cister, em vários países da Europa, deu à agricultura. Assim se procura provar e «reavivar algumas páginas históricas que andam esquecidas de muita gente... (e) desfazer preconceitos de que alguns se deixaram possuir a respeito da ociosidade dos frades» (Vol. II, p. 22); no artigo "A igreja católica e a escravatura", Fortunato de Almeida evidencia, não só a doutrina e a acção libertadora do cristianismo e da igreja, mas também a reabilitação e a nobilitação que esta fez em prol do escravo, procurando torná-lo um «membro legítimo da grande família da humanidade» (Vol. II, p. 2); em "Questões Científicas», reflecte-se, numa primeira parte, sobre as diferentes correntes eléctricas e os efeitos que estas podem ter nas execuções capitais dos condenados à morte, para, numa segunda parte, se darem informações sobre pára-raios e novas experiências levadas a efeito nesta matéria.

Ao nível de relatórios e exposições assinalam-se: «Relatório do Superior das Missões do Real Padroado de Huíla relativo à organização de uma rede de missões para a evangelização e ocupação de todos os sertões da província de Angola e à dotação de um seminário por parte do governo para esse fim»; dividido em duas partes, do bispo de Himeria, D. António Barroso, para o governo um relatório sobre "A prelazia de Moçambique no passado/no presente» e «Missões do Cunene Ocidental». Trata-se, neste último, de uma exposição fei- 
ta pelo Superior das referidas missões, o Padre José Maria Antunes, para o Cardeal Ledokowski, prefeito da Sagrada Congregação da Propaganda. Em todos estes e outros documentos como, por exemplo, o artigo intitulado «Grandes heróis do trabalho» (Cfr. Vol. II, p.p. 83-89), se faz a afirmação do papel importante que a igreja desempenhou, como também se colhem muitas informações preciosas para uma história da colonização e evangelização, não só portuguesa, mas também europeia.

A Revista Contemporânea trata também de assuntos como os que a seguir se indicam:

- No âmbito da História de Portugal - Uma atenção muito particular para as questões africanas, fruto, certamente, da política saída da Conferência de Berlim. De assinalar, aqui, o artigo de Ernesto de Vasconcelos, «África Portuguesa - Portos, empórios do futuro, estradas comerciais, caminhos de ferro", onde se reflecte sobre o modo de se cuidarem e desenvolverem os nossos territórios africanos. O mesmo sentir nas palavras de $\mathrm{F}$. de Almeida em «A defesa das colónias portuguesas».

Quanto às campanhas militares publicam-se: o «Relatório de Mouzinho de Albuquerque sobre a captura do Gungunhana» (Cfr. Vol. II, p.p. 193-215) e «Cartas dos Expedicionários» (Idem, p.p. 113-23), que são missivas de oficiais expedicionários, como Paiva Couceiro e outros, onde nos descrevem conflitos vários. De salientar, também, o artigo de Eduardo de Noronha, «A Guerra de África», onde nos transmite as formas como os portugueses resolveram o conflito que se desencadeou, no Sul de Moçambique, em Outubro de 1894.

Dão-se também notícias sobre o decorrer das campanhas e dos reflexos que elas têm em Portugal. Em «As vitórias da África» (Cfr. Vol. II, pp. 95-96), dá-se conta de um telegrama de Lourenço Marques referenciando a destruição do «Kraal do Gungunhana» e do impacto que esta notícia teve no país, nomeadamente em Coimbra, onde a Academia e a Universidade festejaram.

Ainda no âmbito da História de Portugal, de salientar o artigo assinado por Fortunato de Almeida, «Os jesuítas e a restauração de 1640». Aqui se alude à polémica entre Camilo Castelo Branco e Oliveira Martins acerca do papel que os jesuítas desempenharam na restauração, para o autor concluir que «o primeiro de Dezembro de $1640 \ldots$,.., sem eles, talvez não passasse de um sacrifício inútil» (Vol. I, p. 55).

- Universidade de Coimbra - No artigo "A antiga escola de filosofia conimbricense», Fortunato de Almeida propunha-se, para além de outras 
dimensões, «estudar as feições da escola de filosofia conimbricense, delinear os seus vultos mais notáveis, compendiar o nosso movimento científico desse tempo» (Vol. I, p. 163). Infelizmente, este artigo não foi concluído. Depois de nos falar das primeiras universidades europeias e do movimento filosófico europeu -1 . $^{\mathrm{a}}$ escolástica - o autor fica-se pelas relações de Portugal com esse movimento e pelo intercâmbio da nossa universidade com as outras. Apenas uma breve referência a Pedro Hispano.

Outro assunto é a adesão que a Universidade de Coimbra fez à Constituição dogmática Unigenitus Dei Filius de Clemente XI. Com o título de «Uma página brilhante na história da Universidade de Coimbra», Silva Ramos dá-nos conta desta aceitação.

- Saúde - Neste domínio há a salientar as referências ao Congresso Nacional de Tuberculose, que se realizou em Coimbra, em Março de 1895: transcrevem-se alguns extractos do discurso de abertura pronunciado pelo Dr. Augusto Rocha; fornecem-se, também, estatísticas importantes sobre a doença da tuberculose comparada com outras, no período entre 1 de Fevereiro de 1887 e 31 de Janeiro de 1895; publica-se, igualmente, um texto, que é parte da comunicação que o Dr. Lopo de Carvalho fez ao Congresso, com o título de «A cidade da Guarda considerada como estação para tratamento da tuberculose», onde se apontam alguns requisitos que aquela cidade apresenta e que são benéficos no combate à tuberculose.

No domínio da saúde, uma referência, também, para o artigo assinado com as iniciais do G. B. e intitulado «O perigo do alcoolismo e os remédios», onde se reflecte, não só sobre a questão da embriaguez e o seu aumento em Portugal, mas também sobre as consequências funestas do alcoolismo e remédios a aplicar.

- História da Igreja - No artigo intitulado «Roma e Rússia», extraído da Revue Bénédictine, trata-se da questão religiosa na Rússia e na possibilidade de uma união entre a igreja ortodoxa e a igreja de Roma; repartidos por vários números, fala-se da história do poder temporal dos papas e dos estados pontifícios, nos artigos «A queda e o restabelecimento do poder temporal do papa» e "As origens dos estados pontifícios».

Embora com carácter mais restrito, de assinalar ainda o que se diz sobre a vida e a obra de Santo António de Lisboa, em «Um sábio português no século XIII» e «Santo António de Lisboa em França».

- Literatura Portuguesa - É Fortunato de Almeida quem, num pequeno artigo intitulado «João de Deus», nos fala da obra deste poeta e da homenagem 
que a Academia lhe prestou, chamando-lhe «o maior poeta português desde Camões» (Vol. II, p. 129), num segundo texto alude-se à sua morte e publicamse alguns versos.

- Filosofia - Neste âmbito e citando cientistas vários é Silva Ramos quem reflecte sobre o conceito de vida, no artigo «Problemas de Filosofia Natural. O conceito de vida».

- Educação - Embora incompleto, num pequeno artigo intitulado «Educação da Mocidade» (Cfr. Vol. II, p.p. 311-15), reflecte-se sobre a importância que a educação tem nas gerações; citando exemplos históricos, alude-se, depois, ao papel da Igreja nesta matéria; M. F. Martin, no artigo «A reabilitação da mulher», tece algumas considerações sobre a educação feminina, numa perspectiva de espírito cristão, porque só este «revelou à mulher a excelência da sua natureza e a sublimidade da sua missão» (Vol. II, p. 292).

Para além de outros pequenos artigos como «O proteccionismo do Estado», onde Fortunato de Almeida, tomando como base a obra editada em França de J. Novicow, Les Gaspillages des Sociétes Modernes, tece algumas considerações sobre a vida política e administrativa dos estados e «O palácio de D. Maria Teles», completam esta revista secções, que duraram apenas alguns meses, como: «Crónica Contemporânea», dividida em duas subsecções - Interior e Exterior, onde se dão informações várias sobre o que se vai passando no país e no estrangeiro e "Bibliografia», espaço onde se noticiam obras dadas à estampa, periódicos enviados à redacção e se fazem pequenas recensões críticas.

De assinalar, finalmente, a secção «Varia», onde se alude a assuntos múltiplos como observações sobre o solo da lua, o catolicismo no México, o estado da ciência, etc. 


\section{9・A REVISTA LITERÁRIA}

$\begin{array}{ll}\text { Publicação literária de arte Ẽ crítica teatral e } & \text { Cotas: } \\ \quad \text { bibliográfica } & \text { BN: - } \\ \text { Coimbra, Tip. Minerva Central } & \text { BGUC: - } \\ 1899 & \text { BPMP: - } \\ & \text { BMC: GHC -19/6 }\end{array}$

Director: Eugénio Pimentel

Colaboradores: Augusto de Castro, Filho, Alexandre de Albuquerque, Cunha Viana, Ana de Castro Osório, Guedes Teixeira, Campos Lima, Albertina Paraíso, D. João de Castro e Alfredo Serrano Correspondentes Literários: Alfredo Serrano Austria; Valentim de Magalhães - Rio de JaneiroBrasil; Xavier de Carvalho - Paris; Madame Mary Byngham-Hull - Inglaterra; Jacquemard Diven Novgorod-Rússia; Nevado Valdero - GuadalajaraMéxico; Van Buraxest - S.Petersburg-Rússia; Jaime de Vasconcelos - Atenas.

Formato: $16 \times 22 \mathrm{~cm}$

Periodicidade: Não indica

Preço: 50 réis

Páginas: 16

\section{Objectivo}

Não indica.

\section{Conteúdo}

Revista Literária é uma pequena publicação de que saiu apenas o n. ${ }^{\circ}$, que compreende os fascículos A e B. Segundo informação inserida na própria revista, esta veio substituir no mundo das letras a revista $S p h i n x$.

Como o próprio título e subtítulo indicam estamos perante uma revista exclusivamente dedicada às letras. Para além do estudo intitulado «O Fialho», de Augusto de Castro, Filho, preenchem as páginas desta publicação poesias, contos e romances.

A última página é preenchida com novidades literárias e anúncios gratuitos. 


\section{0 • REVISTA LIVRE}

Coimbra, Tipografia França Amado

$1893-1894$

Redactores: João de Freitas, Valério Pires, João da

Nova e Joaquim Madureira (com o pseudónimo

de Fernão Vaz)

Formato: $11 \mathrm{x} 17,5 \mathrm{~cm}$

Periodicidade: Mensal

Preço: 50 réis

Páginas: N. ${ }^{\circ} 1$ tem 24 páginas
Cotas:

BN: J. 972//7P; P.P.5063P.

BGUC: O.S. 605

BPMP: -

BMC: GHC $-19 / 6$

\section{Objectivo}

Não indica.

\section{Conteúdo}

Trata-se de uma pequena publicação que não passou do número dois, e que aposta, fundamentalmente, na crítica e na contestação do existente.

Com o título de «Questões Religiosas» João de Freitas começa por fazer uma alusão ao movimento de dissolução religiosa iniciado com o renascimento, desenvolvido, depois, com os filósofos da Revolução Francesa, para se lamentar que essa «obra demolidora» (p. 1) não tenha sido, até ao presente, mais profunda. Aponta como razões para o facto, por um lado, a resistência dos defensores da religião e, pelo outro, alguns erros tácticos cometidos pelos apóstolos do livre pensamento.

As temáticas da justiça e do casamento, que a elite burguesa defende, a todo o custo, são igualmente questionadas e contestadas. Referindo-se, por exemplo, ao casamento, escrevem: «crime o dessas ligações com um sifilítico, a quem se perdoa a sífilis, porque ele traz um título de nobreza ao casarão verde-amarelo do burguês» (p. 14). 
Determinadas convenções sociais são, igualmente, objecto de profunda censura. Com o título de "Fialho d'Almeida» critica-se o modo como alguns amigos do escritor o quiseram homenagear, à semelhança de um «qualquer salta pocinhas das letras ou da política» (p. 21).

No artigo intitulado «Nuestros hermanos y los de Riff» denuncia-se e critica-se a luta e a ocupação territorial de que povos do Norte de África estão a ser vítimas. A coberto de «intenções humanitárias e civilizadoras... entram no combate bem armados, bem equipados», mas só «com mira na rapina, na opressão» porque «o Rey niño assim o quer» (p.p. 9-10).

Na secção «Memorandum», pequenas referências à política estrangeira, nomeadamente à espanhola, e alguns comentários, não à política portuguesa, mas à politiquice, porque «em Portugal não há partidos políticos, na acepção científica da palavra» (p. 23). 


\section{$121 \cdot$ REVISTA LOURA}

Publicação bimensal de arte, crítica e verdade

Coimbra, Tip. e Lit. Minerva Central

Março 1899

Colaboradores: Eugénio Pimentel, Costa Cabral e Gomes Neto

Formato: 13,5 x $20 \mathrm{~cm}$

Periodicidade: Bimensal

Preço: Trimestre -250 réis $\bullet$ Avulso - 60 réis

Páginas: 16
Cotas:

BN: -

BGUC: -O.S. 605

BPMP: -

BMC: GHC $-19 / 6$

\section{Objectivo}

Não indica

\section{Conteúdo}

Trata-se de uma pequena revista de criação especificamente literária onde, a par de alguma poesia, há a salientar o texto em prosa "Alda", que é um conto de amores, de autoria de Costa Cabral.

Esta revista veio, depois, a fundir-se com a Revista Literária. 


\section{2 - REVISTA NEGRA}

Coimbra, [s.1]

24 Janeiro 1899 - 11 Abril 1899

\section{Objectivo}

Não indica

Director: Alexandre de Albuquerque

Formato: 9,5 x 13,5 cm

Periodicidade: Não indica

Preço: Avulso - 50 réis

Assinatura -8 fascículos $=300$ réis

Páginas: 20 por fascículo
Cotas:

BN: -

BGUC: -

BPMP: -

BMC: GHC -19/6

\section{Conteúdo}

Revista Negra é uma pequena publicação estudantil composta por três fascículos (A, B e C) e que trata, essencialmente, de assuntos literários.

Para além do conto amoroso intitulado «O aroma das flores», que domina todo o fascículo $\mathrm{C}$, aqui se aprecia e louva, embora em traços muito genéricos, a obra de Almeida Garrett, que «não demoliu para constuir; construindo, demoliu» (Fasc. B, p. 5), que «salvo nas líricas fez sempre arte colectiva (p. 6), que "criou um dos cinco tipos de lirismo-português - o lirismo popular» (p. 7) e que «salvou todo um povo da vergonha de não ter literatura dramática» (p. 9).

O mesmo para Guerra Junqueiro e Fialho de Almeida a quem chamam «os dois últimos guerreiros que arrazaram esta sociedade de cretinos com os formidáveis e certeiros tiros dos seus panfletos» (Fasc. A., p. 9), para concluírem, referindo-se à última fase deste literatos, que «o que mais custa é ver este dois homens de talentos superiores... abandonar as letras para tratarem de vinhos...» (p. 13).

Com o título de «A Epidemia dos talentos» critica-se a onda de literatos que abundam na Academia. Focam-se em especial os nomes de Ferreira Soares e Marques dos Santos. 
Apreciações críticas, também, para obras que vão sendo dadas à estampa e de que são exemplos o Naufrago de Afonso Lopes Vieira e a Apoteose de Daniel Rodrigues e ainda um artigo que Trindade Coelho publicou na Arte.

Também uma certa crítica política à pessoa do rei $\mathrm{D}$. Carlos que desdobrando-se em todas as manifestações da actividade humana, «é, sem mescla, a mais pura glória nacional» (Fasc. A., p. 14) e «tendo nós esta pérola de rei é mesmo um bijou, a maior desgraça que nos poderia suceder era perdê-lo» (p. 16), já que com ele à nossa frente «está solidamente garantida a nossa existência nacional pela aliança inglesa que é nos presentes casos, de todas as alianças a mais proveitosa... para eles» (p. 16).

Como revista estudantil que é, uma pequena alusão à Academia e às suas praxes. 


\section{3 • REVISTA NOVA ${ }^{(1)}$}

Coimbra

Abril, 1893

Director: Henrique de Vasconcelos

Colaboradores: Carlos Mesquita, Fernando de Sousa,

Gustavo Santiago, Francisco Couceiro e outros

\section{Cotas:}

BN: -

BGUC: -

BPMP: -

BMC: -

(1) Apesar das diligências efectuadas, não conseguimos encontrar nenhum exemplar desta revista. Segundo Carneiro da Silva, trata-se de uma publicação literária de que saiu apenas um número, em Abril de 1893 (Cfr. Ob. cit., p. 121). 


\title{
$124 \cdot$ RISOS LISOS
}

\author{
Revista literária bimensal \\ Cotas: \\ Coimbra, Tip. de Luís Cardoso \\ 17 Maio 1897 - 1 Setembro 1897 \\ BN: - \\ BGUC: -O.S. 605 \\ BPMP: \\ BMC: GHC -4
}

Redactores: Joaquim Gomes, José Tomás da Fonseca e Lopes de Oliveira

Colaboradores: Artur Xavier, José Roque, José

Laceiras, Hernani Dorá, José Martins, António

Simões e Mário Grave

Formato: 14,5 x $22,5 \mathrm{~cm}$

Periodicidade: Bimensal

Preço: Trimestre -180 réis

Páginas: 60

\section{Objectivo}

«Sem pretensões a sócios da Academie de la Rose Croix, para que acaba de ser agora eleito com muitíssima justiça, Miga-rans, e a que tem imenso jus o Alexandre de Albuquerque pelas suas locuções de lusco-fusco vestindo ideias vazias como zero, resolvemos fundar esta revista onde o intuito (que motivos de força maior tiveram de alterar muito) é rirmo-nos de tudo o que adregue despertar-nos ou a gargalhada em que se mostram as mandíbulas, ou apenas aquele sorriso, liso, de que reza a trova.

Queremos preencher assim com esta nossa alegria inofensiva de rapazes boémios a estuar nestas páginas, uma lacuna de há muito aberta no jornalismo coimbrão, onde, além das verrinas um pouco mazorras, de sediças, das discussões políticas, onde o jornalista Pedro se ri do jornalista Paulo e vice-versa, e dos mútuos elogios com que alguns literatinhos de cá se mimoseiam, e onde os adjectivos pomposos andam sempre às cavaleiras dos substantivos, elogios que nos fazem rir, nada mais há que nos tire desta apatia que nos avassala.

Dela aspiramos nós sair e, nossa máxima aspiração, fazer sair o leitor, criando esta revista» (Risos Lisos, n. ${ }^{\circ}$ 1, Coimbra, 17 de Maio de 1897, p. 1). 


\section{Conteúdo}

Como revista literária, em Risos Lisos denunciam-se não só a decadência das nossas letras, mas também os males da sociedade burguesa.

A estrutura interna desta publicação é bastante uniforme, ao longo dos seus cinco números. De uma maneira geral, cada número abre com um pequeno texto da redacção (de salientar que o texto do n. ${ }^{\circ} 3$ é um diálogo, muito humorado, entre quatro personagens e tem como título «A melhor arma». (Comédia em um acto), seguindo-se-lhes, depois, um conjunto de outros e rubricas várias.

Em nossa opinião, os artigos mais importantes são os que dizem respeito à sociedade e à questão social. Lopes de Oliveira em quatro artigos com o título de «No Modernismo», em «Burgueses» e ainda em «Carta Aberta», Artur Xavier em «Revoltados» e José Martins em «Os Párias» não só defendem, num discurso de protesto, os pobres e os oprimidos, mas também, em palavras de encorajamento, convidam os operários e os desprotegidos a desenvolverem o espírito de classe e a envergarem as suas blusas, para combaterem «denodadamente pelas (suas) reivindicações sociais» (p. 9).

A decadência das nossas letras é outra das temáticas mais em foco. Para além das notas da redacção é o mesmo Lopes de Oliveira quem, em artigo intitulado "A Literatura Moderna», discorre sobre o que foi e o que é, agora, o romance literário em Portugal. Citando Ramalho Ortigão, Júlio Dinis e Camilo Castelo Branco, acaba por concluir que, desaparecidos estes, restam-nos «nulidades sem valor algum, arquitectos de contos desconchavados, flanando na arte por diversão» (p. 5).

O mesmo se passa com a poesia que «vagueia sem norte, em termos endechas de amor, espreguiçando-se na fofa poltrona da inutilidade, como tudo sem alvo, errante e vagabunda» (p. 6). Depois do desaparecimento de João de Deus, o único poeta que nos resta é, segundo Lopes de Oliveira, Guerra Junqueiro.

Quanto à História de Portugal ela é, também, motivo de preocupação. É que, depois da morte de Oliveira Martins, ela desapareceu, porque «os historiadores de hoje são os autores dos compêndios de instrução primária» (p. 5).

Risos Lisos contém ainda: «Camiliana», onde se transcrevem pensamentos de Camilo; «Bibliografia», espaço para as publicações recebidas; recordam-se poetas como Claúdio José Nunes; textos literários em prosa e poesias várias. 


\section{$125 \cdot$ SAUDADE}

Jornal Poético

Coimbra, Imprensa da Universidade

Abril 1859

Colaboradores: G. Fonseca, A. de Melo Varajão, Severino de Azevedo, Ermelinda M. Varajão,

A. P. Caldas

Formato: 12 x 19,5 cm

Periodicidade: Não indica

Preço: Não indica

Páginas: 64
Cotas:

BN: -

BGUC: -

BPMP: -

BMC: GHC -4

\section{Objectivo}

«Saudade! Quem sonhou esta palavra inspirada pelos anjos, ou trazida à terra nas asas de um eco de Deus; quem a sentiu no murmúrio da fonte, que desliza prateada, quando um raio da lua se banha e se espreguiça nas pérolas do arroio... quem a sentiu nos últimos raios de sol, quando, desmaiando-lhe a cor rubra do horizonte, treme e oscila por sobre o escuro do pinheiral... quem sobre tudo a gemeu sózinho no deserto dos seus amores, no deserto das suas esperanças... oh, por mais que lhe amargue o sofrimento, foi venturoso!

Nem a todos, nem a muitos, é permitido esse êxtase do pensamento, esse alar da inspiração, esse reflexo dos prazeres do céu!

E contudo, há quem sonhe estas venturas, quem as calcule até quem as exprima, como se lhe fossem familiares...» (n. ${ }^{\circ}$ 1, p. III).

\section{Conteúdo}

Trata-se de uma publicação que contém exclusivamente poesia.

A colecção completa não vai além de quatro números, que formam um volume de 64 páginas. A identificação dos diferentes números está assinalada no canto inferior esquerdo da página correspondente. Todos os números apresen- 
tam a mesma estrutura, quer quanto ao formato, quer no que respeita ao número de páginas.

Os seus responsáveis suspenderam esta publicação na altura dos exames, época Junho-Julho, e esperavam continuá-la depois das férias, ou seja, «de Outubro por diante» (p. 64). Tal, porém, não veio a acontecer.

Como o próprio subtítulo o indica, trata-se de um jornal que contém apenas poesia.

Muitos poetas de Coimbra colaboravam em acções de beneficência. Assim aconteceu, por exemplo, em Junho de 1856, no teatro de S. João, no Porto, num espectáculo em favor da creche de S. Vicente de Paula, onde foi recitada uma poesia da autoria de A. P. Caldas e da qual se transcreve a seguinte quadra:

«Aqui não se ostentam os quadros brilhantes, As pompas grandiosas d'um régio festim;

É nobre homenagem prestada à virtude, É um feudo à desdita, - por isso aqui vim» (n. ${ }^{\circ} 3$, p. 33) 


\section{6 - A SEBENTA}

Semanário cómico-sério

Coimbra, [s.1.]

29 Fevereiro 1896 - 28 Março 1896
Cotas:

BN: J. 965//45 P.

BGUC: -

BPMP: -

BMC: GHC -4

Redactores: Simplício, Caturra Pimponibusque

Formato: $20 \times 28,5 \mathrm{~cm}$

Periodicidade: Semanal

Preço: Mensal - 80 réis

Páginas: 4

\section{Objectivo}

«Não são interesses mesquinhos e vaidades mal cabidas, que nos levam a tomar à conta das nossas forças a importante e extraordinária revista - A Sebenta. Não; uma lacuna importante estava por preencher, e como todas as lacunas o têm sido, não queríamos que alguém, quer de dentro quer de fora, se erguesse a dizer-nos (ao curso) que não havia por cá homens capazes de pôr mãos à obra. A hora presente é de luta e por isso é preciso que todos os homens de boa vontade empunhem as armas e entrem em campo.

O operário não tem pão; propomos com Mons. Bourgeois que o estado o aposente, mas com ele rejeitamos o socialismo.

A guerra está hoje acesa nas quatro partes do globo; propomos que se formem grandes federações para evitar a guerra, mas entendemos que a guerra produziu sempre benéficos resultados.

340 Nós os inteligentes e os meninos bonitos (ex.: Coelho Manso e Neto); nós os literatos (ex: Correia Teles e Simões Baião); nós os ursos (Macário e semelhantes); nós os músicos (a maior parte); nós os cábulas (uma outra não pequena); nós, enfim, que com nossos feitos e obras cegaremos os grandes sóis, os grandes talentos, nós, não podíamos deixar de levantar bem alto o estandarte da solidariedade jurídico...académica. Presunção e água benta, cada um toma a que quer.

E agora, um ao leme e dois aos remos, lá vamos nós, Mondego abaixo, sobre as águas murmurantes, enquanto a cabra nos fizer andar neste errar... A 
nossa barca já flutua! Ó Pedro deita ali uma tábua ao cais; segura tu o Caetano; vá rapazes, toca a entrar; cá está a bolsinha aberta, são quatro vinténs e no fim da viagem beberemos todos à solidariedade académica e à irmã querida de Minerva!» (n. ${ }^{\circ} 1$, pp.1-2).

\section{Conteúdo}

A Sebenta é um pequeno periódico ilustrado e litografado, que não foi além de oito números, que se insere na categoria de publicações que classificamos de entretenimento e informação, porque a sua finalidade principal é divertir, dizendo algumas verdades. Daí o carácter «cómico-sério» com que, por vezes, se afirmam.

De interesse bastante modesto, esta pequena revista foca, fundamentalmente, assuntos e factos relativos à comunidade estudantil, acompanhados, por vezes, de jocosas observações. Para além de uma breve referência à morte do Hilário, de alusões às sebentas e erros que comportam, às «chamadas» que os professores fazem nas suas aulas, a feitos e peripécias de colegas que se afirmam, no seio da comunidade, por determinadas características e singularidades, tecemse, também, breves considerandos sobre a vida política na academia. Numa referência às principais facções partidárias, comenta-se: «Quanto ao Centro Monárquico, lá está ele com a sua bandeira a drapejar aos ventos da Rua do Norte. Do «Centro Republicano» dizem-nos que vive» (n. ${ }^{\circ} 1$, p. 3, col. 2).

Sobre questões de política partidária, diz-se ainda: «O partido republicano tem recrutado soldados aguerridos nos primeiros anos das diversas faculdades... o partido monárquico tem conseguido muitas adesões entre quartanistas e quintanistas. Todos os caloiros lá de casa estão em 2a classe com interrogação» (n. ${ }^{\circ}$ 3, p. 2, col. 1).

Completa-se esta pequena revista com poesias e breves referências à insurreição em Cuba, às campanhas portuguesas em África e à ocupação deste continente por ingleses, franceses, italianos e alemães. Numa crítica a esta invasão e ao que ela representa, questionam-se: «Quando é que a África será para os africanos»? (n. ${ }^{\circ} 1$, p. 2). 


\section{$127 \cdot$ A SILFIDE}

Coimbra, Tip. J. T. A. Pacheco

Outubro 1857 - Janeiro 1858

Administrador: Joaquim Teotónio de Andrade Pacheco

Redactores: Augusto César Rodrigues Sarmento, Augusto César da Silva Matos, António Xavier Rodrigues Cordeiro e J. A. Sanches da Gama

Formato: 14 x $22 \mathrm{~cm}$

Periodicidade: Trimensal

Preço: Não indica

Páginas: 64
Cotas:

BN: J. 1294 B.

BGUC: -

BPMP: -

BMC: GHC -2

\section{Objectivo}

Não indica

\section{Conteúdo}

É um pequeno periódico, de interesse relativamente modesto, de que se publicaram oito números, todos com o mesmo formato e número de páginas, onde se escreveram, exclusivamente, poesias.

Trata-se, assim, de um jornal poético por excelência. 


\section{$128 \cdot$ A SOGIAL}

Revista Quinzenal de Estudos Sociais

Coimbra, [s.1.]

9 Janeiro 1897 - 9 Março 1897
Cotas:

BN: J. $964 / / 20$ P.

BGUC: $10-9-25$ - 24

BPMP: -

BMC: GHC -3

Colaboradores: José Emídio Soares da Costa Cabral,

A. Carlos Borges, Guedes Teixeira, Teixeira Bastos,

Magalhães Lima, Jacinto Nunes, Gonçalves

Cerejeira, Costa Ferreira, Luís Duarte e Heráclito

Fernandes

Formato: 16 x $22 \mathrm{~cm}$

Periodicidade: Quinzenal

Preço: Não indica

Páginas: 64

\section{Objectivo}

«Não vamos traçar um programa, o nome que demos a esta revista é o bastante para indicar o caminho que de nós para nós mesmos traçamos; vamos apenas dizer quem somos, de onde vimos e para onde vamos.

Novos, crentes que o futuro trará melhores dias... tomamos sobre nossos ombros a árdua missão de, por o caminho da justiça e do bem, levarmos, quanto em nossas forças caiba, o pão do espírito aos que dele são pobres, o gládio augusto da justiça social aos oprimidos, fazermos chegar às mãos daqueles que, em esfrangalhadas esteiras, levam uma vida de dor, de miséria e talvez de infâmia, a luz da razão, o eco dos seus direitos.

Aos ricos e poderosos levaremos as nossas preces, implorando pão, agasalho, amor e fraternidade; para os pobres e que nada valem, seremos mensageiros do progresso, da luz e da civilização...

Vindos de diversos cantos do país... aqui estamos; novos, sem valor talvez, animados de uma confiança sem limites, pregando o evangelho do Cristo, respeitando César, e, reclamando em favor de Job, não atacando homens, por todos pedindo, dizendo àquele; - sê justo! - e a este: - sê prudente!; - somos os pregoeiros do progresso, os mensageiros da civilização. 
Vindos da humilde cabana, do escalvado das serranias, e do nobre solar brasonado, das grandes cidades, aqui vamos caminhando sempre no trilho da honra, no caminho da verdade, para a perfeição social... Estamos apresentados.

A Social não é produto híbrido de diversos ideais políticos, miscelânea confusa de muitos modos de pensar; é o lugar em que o maior reaccionário, o conservador puro sangue, o republicano oportunista, o radical pedindo pólvora, o socialista impetrando justiça, e, o anarquista reclamando-a em nome da sociedade, têm lugar para fazer as suas reclamações; a todos, é permitido erguer a voz..., com a condição única de o fazerem de luva branca e baseando-se em factos e teorias que tenham um cunho científico.

A Social não aparece como capricho nosso... é uma necessidade urgente, ideia por nós amadurecida, publicação muito pensada...

A Social não tem política; Sua Majestade El-Rei o Senhor D. Miguel II e os seus prosélitos podem ter aqui um paladino...; Sua Majestade El-Rei o Senhor Dom Carlos I tem entre nós uns defensores a tudo prontos, atentos e diligentes, se nos convencer que segue um rumo racional e útil à sua, e também nossa, Pátria.

Sua Excelência o Presidente da República Portuguesa pode contar connosco... Os socialistas... apenas nos provem que, postos os seus ideais em prática, eles nos levarão, por caminho seguro, à felicidade humana.

Aqui, no extremo ocidente da Europa, recostado sobre o mar, adormecido nos braços das glórias passadas, jaz um Povo que foi grande...

O egoísmo empolgou audaz e horrível este Povo... Portugal... parece ruir já no despenhadeiro formidável do desaparecimento dos povos, fruto da sonolência em que nos encontramos, da ignorância em que nos vimos. Como grito de protesto contra essa sonolência, contra essa ignorância, aí está - $A$ Social.

344 Quanto à segunda dúvida, a Literatura é também uma parte da alma da nação e aí lhes oferecemos uma secção literária...

Pregamos a Paz; esta revista tem uma secção dedicada á sua defesa... Como pregoeiros do progresso, caminhamos na sua senda intelectual e organicamente; como mensageiros da civilização, erguemos bem alto o lema de 1789:Liberdade, Igualdade e Fraternidade.

O nosso programa, como já dissemos, encerra-se em poucas palavras:

- Liberdade e Honra, Igualdade e Justiça, Fraternidade e Amor» (A Social, n. ${ }^{\circ}$, Coimbra, 9 de Janeiro de 1897, p.p. 1-4). 


\section{Conteúdo}

Trata-se de uma pequena revista que, abordando questões concretas da sociedade da época, procura não só esclarecer e instruir, contribuindo assim para um melhor encontro de soluções, mas também revolucionar mentalidades. Em artigos vários, na «Secção Doutrinária», os seus colaboradores, ao denunciarem e criticarem situações, não escondem as simpatias que nutrem pelos cânones positivistas e pelas ideias republicanas. Com alguma razão se intitulam "pregoeiros do progresso» e «mensageiros da civilização».

Compõe-se esta pequena colecção de quatro números, todos com o mesmo formato e número de páginas. Em sinal de homenagem, a redacção da revista dedicou o último número ao Prof. Guilherme Alves Moreira, da Faculdade de Direito.

Com excepção para o primeiro número, em termos de estrutura interna, todos os outros apresentam uma «Parte Literária», de pequena dimensão, e uma «Parte Científica». Naquela inscrevem-se textos literários, nomeadamente poesia. Destacamos, aqui, uma da autoria de Costa Ferreira, intitulada «Via Dolorosa», por ser um símbolo da literatura. finissecular, um reflexo vivo das realidades e convulsões da época e, como tal, de uma certa crise social e mental.

A «Parte Científica» é composta por artigos, alguns deles repartidos por diferentes números, que abrangem temáticas diversas e onde se inclui a já referida «Secção Doutrinária».

Nestes artigos perpassam dois grandes temas: o mais importante é, indubitavelmente, a Questão Social e as reflexões múltiplas que sobre esta matéria Costa Cabral produz. Em seu entender, esta questão é «a primeira de entre todas, como a maior das preocupações particulares e públicas» (n. ${ }^{\circ} 1, \mathrm{p}$. 6); o outro tem a ver com a célebre Questão Ibérica, ou seja, o debate entre os partidários do unitarismo e do federalismo. Citando autores vários e a moção aprovada, por aclamação, no Grupo Republicano de Estudos Sociais, Gonçalves Cerejeira não só faz uma crítica à monarquia e seus adeptos, como também afirma, peremptoriamente, que «a organização federal dos Estados livres da Península Ibérica impõe-se irresistivelmente a todos os espíritos sensatos como uma conquista do progresso e uma garantia da nossa liberdade autonómica» (n. ${ }^{\circ}$ 3, pp. 34-35). Em seu entender, a federação ibérica só a República a pode realizar. 
Em artigos outros, questões há, mais diluídas, que podemos sintetizar em rubricas como:

- Educação e Sociedade: o Instituto de Coimbra e os cursos nocturnos para operários; educação feminina (mentalidades; a questão da união livre - suas implicações);

- Poder e Contra-poder na Sociedade: o triângulo: massas populares, instrução e política - Que relação?; a contestação do existente (Anarquismo e Colectivismo); a importância do poder militar (exército) numa nação;

- Ciência e Sociedade: sociedade de hoje e sociedade do futuro (a sujeição do homem e suas acções aos princípios racionais da ciência; a importância da ciência social).

Para além da apreciação de algumas obras dadas à estampa como, por exemplo, Socialismo libertário ou Anarquismo de Silva Mendes e de algumas críticas ao governo pela perseguição movida ao Prof. Guilherme Moreira, por este «ter crenças republicanas» (n. ${ }^{\circ}$ 2, p. 29), completam esta publicação dois títulos: «Política Externa. Carta d'um diplomata», onde se indicam as grandes questões que dominam o mundo, em finais de 1896, e «Consultas», espaço reservado a questões e respostas diversas tais como: «Que influência exerce em nossos tempos a religião para a regular existência, desenvolvimento e transformação das sociedades humanas?» (n. ${ }^{\circ}$ 1, p. 10) e «Que lugar deve ocupar a matemática na classificação geral das ciências?» (Idem, p. 11). 


\section{9・SOCIOLOGIA E DIREITO ${ }^{(1)}$}

1891

Cotas:

BN:

BGUC: -

BPMP: -

BMC: -

Responsáveis: Abel de Andrade e Fernando Martins de Carvalho

(1) Segundo nos informa Carneiro da Silva, esta revista não passou do prospecto (Ob.cit., p. 126) 


\section{$130 \cdot$ SUL DE PORTUGAL}

Coimbra, Tip. de A. D. Areosa

1 Abril 1874 - 5 Junho 1874
Cotas:

BN: -

BGUC: B - $18-42-7$ - A

BPMP: -

BMC: GHC -21/3

Formato: 34,5 x $46,5 \mathrm{~cm}$

Periodicidade: Semanal

Preço: Trimestre - 500 réis

Páginas: 4

\section{Objectivo}

«Não vendemos as nossas penas, nem nos pomos em almoeda. Não nos amedrontam ameaças, nem tememos os inimigos. Somos moços crentes e apóstolos de uma ideia sublime, grandiosa - progresso.

Quem quiser marchar na rectaguarda, que marche, nós marcharemos no piquete avançado... Somos soldados voluntários de um grande exército, que não enverga farda nem botões amarelos, mas que empenha a pena para defender os interesses da sua pátria» (n. ${ }^{\circ}$, p. 1, col. 1).

\section{Conteúdo}

Apesar de se desconhecerem os responsáveis por esta publicação, por nela não estarem indicados quaisquer nomes, sabemos, contudo, que este periódico é redigido por estudantes algarvios. Refere-o Carneiro da Silva (Ob. cit., p. 127), pode deduzir-se do próprio título do periódico, à semelhança do que já havia acontecido com Grémio Alentejano (1861) e O Minho (1862), e confirma-o um artigo inserto num dos seus números, a propósito do Seminário de Faro, onde se lê: «será bom que façamos saber aos nossos leitores que alguns dos jovens académicos que redigem este jornal estiveram naquele estabelecimento» (n. ${ }^{\circ} 8,24$ de Maio de 1874, p. 2, col. 1).

Simpatizantes, politicamente, das ideias republicanas, comungando na ideia de progresso, são seus propósitos lutar pelos interesses da pátria, em geral, e pelos do Algarve, em particular. Daí o carácter político e noticioso da publicação. 
Segundo Carneiro da Silva, a colecção completa deste periódico é de 14 números. Infelizmente, nas bibliotecas de Coimbra existem apenas 5 números. Deve tratar-se de uma colecção bastante rara, na medida em que até Cândido Augusto Nazaré, um apaixonado coleccionador de coisas de Coimbra, só «tem alguns números», conforme nos refere Pinto Loureiro (ob. cit., p. 65, col. 2).

Nos números consultados, a estrutura interna é idêntica em todos. Um artigo de fundo, que pode ter ou não título, a dominar a primeira página e, depois, artigos outros, que vão de encontro à renovação de mentalidades e, consequentemente, a uma certa sensibilização dos leitores.

É, fundamentalmente, nos artigos de fundo que se tecem fortes considerações críticas aos governos e suas políticas. Com o título de «A política no Algarve», reconhece-se que esta região do país paga para tudo, mas carece de grandes melhoramentos como estradas, caminhos de ferro e escolas. Contestando esta política, escrevem: «dizemos a todos os partidos -a nossa política não é a que vós praticais; sois os vendilhões do templo, saí, dai lugar às novas gerações que trazem a nova ideia» (n. ${ }^{\circ} 7$, p. 1 , cols 3 e 4).

O mesmo sentido crítico nas visitas que os ministros fazem ao Algarve. Em «O Sr. Fontes no Algarve», acusam-no, não só de esbanjar os dinheiros públicos, mas também de corrupção: «Quem encomenda os festejos? O governo. Quem os paga? O povo. E o ministro como recompensa? Com a corrupção» (n. ${ }^{\circ}$ 13, p. 1, col. 2).

Mas é, também, nos artigos de fundo que, com entusiasmo e esperança, se avança na prossecução da nova ideia que é a República. Com o título de «Emílio Castellar», estes jovens redactores dão-nos conta, não só da sua adesão às ideias republicanas, mas também do acolhimento que Coimbra e a Academia dispensaram ao ex-presidente da República Espanhola, na visita que fez a esta cidade. Do discurso que então proferiu, recorda-se o dever que os estudantes tinham em contribuir para a realização dos Estados-Unidos da Europa e que esse caminho só era possível com a República.

Mas a divulgação do projecto republicano passa, também, por outros textos como, por exemplo, «O Seminário de Faro». Aqui se fala do que deve ser a educação do clero, das condições que devem prevalecer num bom seminário, para se concluir que aquela instituição está muito longe de satisfazer os requisitos necessários, uma vez que as pessoas que a servem não têm a formação adequada. 
Críticas igualmente duras ao clero e um apelo às autoridades em «O Partido Liberal e a reacção», onde se dá conta do mal que os jesuítas provocam no povo. Jesuitismo é sinal de abuso e de fanatização. Daí o apelo às autoridades administrativas e ao bispo para intervirem, uma vez que não são correctos os meios usados pelos religiosos do convento de Santa Teresa, pois já «é tempo de não zumbar dos direitos dos cidadãos» (n. ${ }^{\circ} 13$, p. 2, col. 3).

Para além de algumas poesias, completa-se este jornal com as seguintes secções: "Revista Estrangeira», onde se dão notícias do que se vai passando além-fronteiras; «Secção Oficial», onde se dão resumos do Diário do Governo e se publicitam os actos oficiais que interessam ao Algarve; "Correspondência», onde se faz eco do que diz a imprensa e do que se vai passando por Lisboa, Alcantarilha, Silves, Olhão, Lagos e Portimão; «Secção Noticiosa», com notícias várias de Coimbra e outros lugares.

De salientar, finalmente, a publicação que se faz sobre o movimento do Hospital da Universidade e os folhetins intitulados «Instrucção Primária» e «A Educação da Mulher», ambos da autoria de D. António da Costa.

Uma parte da última página é reservada a publicidade. 


\section{1・TIRA-TEIMAS}

Semanário Universa

Coimbra, Imprensa Literária

1 Novembro 1861 - 11 Abril 1862
Cotas:

BN: J. 209 B.

BGUC: -

BPMP: -

BMC: GHC -2

Director: Rodrigo Augusto Cerqueira Veloso

Colaboradores: João de Deus Cerqueira Lobo, Bruno de Vasconcelos, J. Simões Dias, Elmano da Cunha, Santos Valente, Abreu Gouveia, Rodrigo Menezes, Caetano Teixeira Coelho, L. C. Simões Ferreira, Henrique Ferreira, Teófilo Braga, Eugénio de Barros, Alexandre Braga, Alberto Sampaio, Antero de Quental, Correia Bandeira, António Barata, Zeferino Brandão, Faustino Sarmento e outros

Formato: 15,5 x $22,5 \mathrm{~cm}$

Periodicidade: Semanal

Preço: Trimestre - 400 réis

Páginas: 192

\section{Objectivo}

«Santo Deus! Misericórdia... misericórdia... Que século, que época e que terra!

Coimbra, nobre solar da crítica, capitólio da literatura, alcaçar da ciência, que mal esperas do inocente, inocentinho, prodigiosamente inocente Tira-Teimas, para o receberes tão friamente e sem sobressaltos de júbilo?...

O Tira-Teimas, senhores, não tem aspirações a Tiranete de Tragédia, nem é negra a bandeira que o guia; longe disso a sua missão é toda de paz.

A sua profissão de fé, franca e leal, lavra-se em duas palavras - a batina.

Representante único da Academia nas lides da imprensa, a nada mais mira o Tira-Teimas que a ser o eco de tantas vocações esperançosas que aí definhariam à míngua de um periódico, onde estampar suas deliciosas produções» (n. ${ }^{\circ}$ 1, p. 1).

\section{Conteúdo}

Tira-Teimas é uma publicação literária que procura abrir as suas colunas a poetas e prosadores, para nelas verterem as suas produções, em virtude da es- 
cassez, no seio da Academia, de publicações deste género. Aliás, alguém, referindo-se a este periódico, lhe chamou «a arca da aliança da academia», na medida em que «vai guardando alguma coisa que encante o espírito» (n. ${ }^{\circ}$ 7, p. 53, col. 1).

A colecção completa deste periódico é de vinte e quatro números, todos com a mesma estrutura, tanto no formato como na paginação, formando um volume com 192 páginas.

Tratando-se de uma publicação de carácter literário, é a produção poética, que aqui é muito variada, que ocupa um lugar por excelência, quer através da simples quadra e soneto, quer em pequenos poemas como o intitulado «Bruxedo. Poemeto Nacional» de Bruno Teles de Meneses de Vasconcelos, que «é uma genuína inspiração dos nossos hábitos e crenças nacionais em matéria de superstições populares» (n. ${ }^{\circ}$ 2, p. 12, col. 1). Também textos literários em prosa, sejam eles fragmentos de livros em preparação ou a publicar, sejam histórias, em contos e romances, como o intitulado «Um padre como há pou$\cos »$.

Também as questões relacionadas com a língua e a literatura dominam, em artigos que se repartem por vários números como acontece, entre outros, com "Um lance de olhos pela língua», onde Caetano Teixeira Coelho reflecte sobre a perda da vernaculidade de nossa língua. Em seu entender, esta perda deve-se a causas como: influência da imprensa, filosofia do século, a educação com as consequentes aprendizagens das línguas francesa e inglesa, as ciências e até as artes «nos mil produtos, que do estrangeiro nos manda, manda-nos mil desonestidades para a língua» (n. ${ }^{\circ}$ 12, p. 89, col. 1) e, finalmente, as traduções. Conclui que, em matéria de idioma nacional, cabe ao governo uma palavra, nomeadamente, o mandar reimprimir muitos bons livros clássicos que, agora, são raros. Citam-se autores como D. Francisco Manuel de Melo e Francisco 352 Rodrigues Lobo, entre outros.

Também um ensaio crítico de Henriques Ferreira ao poemeto de Elmano da Cunha, A Filha do Deserto, que, depois, levou a uma réplica entre aquele e Abreu Gouveia.

No domínio da literatura ainda um pequeno artigo sobre Camilo Castelo Branco.

De salientar ainda a apreciação crítica de algumas obras como, por exemplo, aquela que Rodrigo Veloso, em cinco pequenos artigos, faz a Arzila, que é um romance histórico da autoria de Bernardino Pinheiro; também Magalhães 
Cardoso ao livro Nobiliarquia Conimbricense de António Maria Seabra de Albuquerque.

No campo da história, referências à morte de D. Pedro V e do Infante D. João.

Completa-se este periódico com uma secção permanente, «Crónica», onde, como o próprio título indica, se dão notícias várias e relatam factos e acontecimentos diversos passados, não só em Coimbra, mas também em outras localidades. Do meio da publicação em diante, um espaço para o teatro, na secção «Revista Teatral».

Finalmente, alguns passatempos com charadas, logogrifos e adivinhas. 


\section{2 • O TRABALHO}

Semanário Democrático

Coimbra, Imprensa da Universidade

17 Março 1870 - 20 Junho 1870

Redactores: Manuel Emídio Garcia, Fernando Crisóstomo, Adriano Antero de Sousa Pinto, Manuel Joaquim Massa e Custódio de Almeida

Colaboradores: Manuel de la Reville, M. Azevedo Pacheco, G. Vasconcelos Abreu e B. Doutel

Formato: 21,5 × $30 \mathrm{~cm}$

Periodicidade: Semanal

Preço: Coimbra - 600 réis (Trimestre)

- Fora de Coimbra - 700 réis

Páginas: 88
Cotas:

BN: J. 443//17 M.;

J. $2458 / / 44$ V.

BGUC: $10-1-24-4$;

$10-9-13$

BPMP: P/B/1085

BMC: GHC - 4

\section{Objectivo}

“O Trabalho é um jornal modesto. Os apóstolos que nele evangelizam são obscuros e sem nome; mas vale muito, porque são nobres, elevadas e santas as doutrinas que defende a propaga...

Empreendendo esta humilde publicação, fora nosso intuito: Dedicar ao Trabalho e estudo algumas horas vagas, promovendo assim a nossa própria instrução e desenvolvimento: Esclarecer o povo, os homens pobres de conhecimentos, indicando-lhes um melhor futuro e remédio para os seus males, fazendo-os conhecer o que são, o que valem e qual o seu destino, obrigações e direitos: Combater falsas ideias e instituições caducas, que a civilização e o progresso não podem aceitar, substituindo-as por outras mais justas, necessárias, verdadeiras e em harmonia com a natureza humana.

Aos homens de ciência e ilustração, a quem os nossos escritos serão de pouco ou nenhum auxílio, não é dirigido o nosso trabalho.

Os mestres pedimos alento, conselho e protecção, a todos benignidade e acolhimento...

Alumiados pela luz esplendida da razão, protegidos pela força invencível da justiça, da moral e do direito, alimentados pelo estudo e reflexão, animados pela coragem e consolação de uma consciência austera, teremos por aspiração in- 
cessante e desejo fervoroso - o maior bem, o maior progresso de cada um e de todos. Apóstolos decididos e intrépidos da liberdade, desse sublime atributo do homem... não cessaremos de o proclamar em todas as suas grandiosas manifestações, como defenderemos todos os demais princípios e leis que regem o homem, como indivíduo e membro da sociedade. Não podemos transigir com os abusos e aberrações sociais, com práticas inveteradas, absurdas e anti-progressistas, com certas ideias falsificadas e costumes corrompidos...

Queremos que se melhore a sorte de todos, e nesse intuito trabalharemos para que sejam aliviados e protegidos os que sofrem.

Sois exaltados e revolucionários, sonhais, as vossas ideias não podem ter aplicação, - exclamam os tímidos conservadores e os inimigos da luz e do progresso, que tudo esperam do passado e nada do futuro...

Sonhamos, porque cremos na lei irresistível do progresso indefinido, na perfectibilidade sempre crescente do género humano e nestas aspirações ardentes das nossas almas...

Somos revolucionários, mas não queremos o derramamento de sangue, nem as lutas fratrícidas... Somos revolucionários nas ideias e na instrução, pela palavra e raciocínio, com o trabalho, virtudes e exemplo...

Não somos filhos ingratos para rejeitar o passado... Portugal deve mostrar, como sempre, que não é indiferente a estes movimentos, que tendem a melhorar a sorte das nações» (n. ${ }^{\circ}$ 1, p.p. 1-2).

\section{Conteúdo}

Segundo nos informa Carneiro da Silva, O Trabalho foi «o primeiro periódico republicano que veio à luz em Coimbra» (Ob. cit., p. 128). Eram propósitos dos seus responsáveis esclarecer o povo, divulgando não só uma nova mensagem política, mas também criticar ideias e denunciar atitudes e comportamentos, sobretudo dos responsáveis políticos. O discurso utilizado é, simultaneamente, de esperança e de protesto. De esperança, porque a República é a consagração da tríplice democracia: religiosa, civil e política; de protesto, porque é preciso abafar «a náusea que nos causam as pústulas gangrenosas dos nossos corpos políticos» (n. ${ }^{\circ}$ 3, p. 21, col. 2).

A colecção completa de $O$ Trabalho compõe-se de onze números. Todos eles apresentam o mesmo formato e número de páginas. 
Quanto à sua estrutura interna poderemos dizer que, de um modo geral, a primeira página é dominada por um artigo de fundo, seguindo-se um conjunto de textos e artigos, sobretudo de origem doutrinária. De salientar a existência das secções de «Política Externa» e «Política Interna», onde se dão a conhecer acontecimentos políticos, pondo assim o leitor a par do que se passa lá fora, mas também internamente, discutindo, analisando e apreciando actos da governação e a marcha dos negócios públicos.

Nos artigos de $O$ Trabalho perpassa um grande tema: propagandear a mensagem republicana. Esta missão desenvolve-se em textos e artigos como: "Democracia e Demagogia», "Necessidade de organização do partido democrático em Portugal», ambos da autoria de Fernando Crisóstomo; "Os missionários» e "O veto" de Manuel Joaquim Massa; "A República» do leitor M. Azevedo Pacheco e «Refutação dos principais argumentos com que se pretende combater o governo republicano», assinado por F. R. entre outros. Para além de louvores à Revolução Francesa, que intitulam de "grande revolução" (n. ${ }^{\circ}$ 1, p. 3, col. 2), aos seus ideais de Liberdade, Igualdade e Fraternidade com os quais se identifica a democracia, da defesa dos direitos individuais, das críticas às ideologias anarquista e comunista que acusam de demagógicas; a afirmação de anticlericalismo, quando se acusam os padres de serem os "pregadores da falsa ideia» (n. ${ }^{\circ}$ 1, p. 6, col. 2) e, por isso, se aconselham, face ao seu zelo, a irem para a Ásia e para a África, onde são mais precisos; reflexões várias sobre a teoria da soberania popular e o veto dos reis que «é o não quero formal, oposto à vontade legítima dos representantes da nação» (n. ${ }^{\circ}$ 5, p. 35, col. 1); críticas aos adeptos da monarquia, porque a república não tem um evangelho onde se leia "favoritismo, hereditariedade, privilégio, sinecura" (n. ${ }^{\circ}$, p. 27, col. 2) e defesa importante de um partido democrático forte, nas suas convicções, que leve a luz da ciência e do progresso aos homens mais desfavorecidos. Reconhecimento da necessidade e importância que a instrução pública tem num país, conforme refere B. Doutel no artigo intitulado mesmo «Instrução Pública».

A enriquecer esta mensagem republicana, Manuel Emídio Garcia, no artigo «O pauperismo", fala-nos sobre a história da pobreza e suas conexões políticas, para esclarecer que com a República haverá igualdade jurídica e liberdade económica.

Acompanham ainda as ideias republicanas reflexões sobre o que tem sido a vida da realeza e das monarquias. Adriano Antero, por exemplo, no seu artigo "A realeza em frente da razão» não deixa de reflectir sobre o que foi a sua his- 
tória, para dizer que «a realeza tem sido forçada a reconhecer o grande princípio da soberania popular, embora reaja contra ele a cada instante» (n. ${ }^{\circ} 1$, p. 5 , col. 2).

Fortes críticas também para o militarismo do duque de Saldanha e para as prepotências dos seu ministério, assim como para o iberismo unitário que jamais se aceita, porque a haver uma união com a Espanha, ela só será feita de «uma única forma - a república federativa» (n. ${ }^{\circ} 9$, p. 65 , col. 2).

Completa-se este periódico com a análise e apreciação de algumas obras, nomeadamente, o Cântico dos Cânticos sobre o qual G. Vasconcelos Abreu nos diz que o seu «carácter predominante é o sensualismo; nada tem de religioso, nada nos fala de Deus» (n. ${ }^{\circ}$ 8, p. 62, col. 1), a Filosofia do Direito de J. M. Rodrigues de Brito e O Papa-Rei e o Concílio de Manuel Nunes Geraldes.

Publicidade também para o jornal República a aparecer em Lisboa e do qual se publica o programa.

De referir, finalmente, uma poesia de Guerra Junqueiro intitulada "Orgia», já publicada em $A$ Folha, mas, agora, novamente reproduzida, porque ela «pinta em linguagem poética o abismo que separa a demagogia da verdadeira república» (n. ${ }^{\circ}$, p. 71, col. 2). 


\section{3・O TROVADOR}

Colecção de poesias contemporâneas redigidas por uma sociedade de académicos

Coimbra, Imprensa de E. Trovão

$1844-1848$

Redactores e Colaboradores ${ }^{(1)}$ : A. Cabral Couceiro, A. Gonçalves Dias, A. Maria do Couto Monteiro, A. Pereira da Cunha, A. de Serpa, A. X. R. Cordeiro, A. Lima, Aires de Sá Pereira e Castro, Evaristo Basto, F. de Castro Freire, F. Palha, H. O'Neill, J. da Costa Cascais, J. Freire de Serpa, J. Frutuoso, D. João de Azevedo, J. de Lemos, J. M. Borges, J. A. Palmeirim, L. Correia Caldeira, L. da Costa Pereira, L. da Silva Mouzinho de Albuquerque, Nuno Maria de Sousa Moura

Formato: 12,5 x $20 \mathrm{~cm}$

Periodicidade: Não indica

Preço: Não indica

Páginas: 398

\section{Cotas:}

BN: J.2414P.;P.P.22994 V.

BGUC: -

BPMP: U - 1 - 40

BMC: GHC -2

\section{Objectivo}

Este periódico não indica o objectivo da sua publicação. No entanto, para melhor o situar e definir, transcrevemos algumas linhas de um artigo publicado na Revista Universal Lisbonense, de 20 de Janeiro de 1848, e reproduzido no final do volume que contem a colecção de $O$ Trovador.

«O Trovador não é um simples jornal, que represente o pensamento de um homem, nem é também a expressão de uma corporação como talvez parece...

Os sons maviosos com que a sua lira louva a religião de nossos maiores, as canções em que a honra e o valor português brilham cercadas pela glória, são o pensamento da nova geração. O Trovador irá até à posteridade coroado com

(1) Não faz a distinção entre redactores e colaboradores. 
os louros que o adornam, porque traz no peito como divisa a cruz, e traja as cores nacionais» (Apud, O Trovador, p. 392).

\section{Conteúdo}

Compõe-se $O$ Trovador de 24 números dedicados, exclusivamente, à poesia.

Todos os números têm o mesmo formato e número de páginas, dezasseis, formando um volume com 384 páginas. A identificação de cada número é feita no fundo da página respectiva.

De salientar a existência, no fim do volume, de mais um número, que inclui um artigo da Revista Universal Lisbonense, de 4 de Julho de 1844, precedido de uma advertência de A. F. de Castilho. Contém, também, um juízo sobre $O$ Trovador, extraído da mesma revista com data de 20 de Janeiro de 1848, perfazendo-se, assim, um total de 398 páginas, incluindo o índice. 


\section{4 - O ULTIMATUM}

Folha Académica

Coimbra, Tip. Operária

23 Março 1890

Colaboradores: Afonso Costa, Silvestre Falcão,

A. Carvalho, Albertino de Pinho, Alberto Osório

de Castro, Armando Zuniga, António José de

Almeida e B. Fraústo

Formato: 35 x $45,5 \mathrm{~cm}$

Periodicidade: Bisemanal

Preço: Avulso - 20 réis • Série de 24 nos -500 réis

Páginas: 4
Cotas:

BN: J. $775 / / 55$ A.

BGUC: -

BPMP: -

BMC: GHC -152

\section{Objectivo}

«Somos anti-monárquicos. Esta simples e formal declaração parece que bastaria que definir a nossa futura linha de conduta, encerrando-se nela tudo quanto possa dizer-se acerca dos intentos do nosso jornal. Não obstante julgamos ser dever nosso acrescentar o seguinte.

Não atacamos pessoas, nem apreciamos individualidades particulares; mas discutiremos princípios aberta e francamente, comentaremos as ocorrências com a maior imparcialidade e combateremos com toda a energia do nosso ânimo as instituições monárquicas, por nos parecer que elas são perfeitamente antagónicas com as aspirações populares, e porque reconhecemos, como todos os homens de mente sã reconhecem, que no estado actual das sociedades há uma

360 desarmonia completa entre as conveniências de uma coroa e as legítimas necessidades de um povo.

Não nos iludimos acerca do futuro do nosso jornal. Sabem de antemão que graves obstáculos se lhe hão-de antepor e que terá de ser dificultosa e árdua a nossa tarefa...

Seremos intransigentes em questões de interesse público; e enquanto nos alentar um sopro de vida havemos de sempre, e por todos os modos, pugnar pelo engrandecimento da pátria, pelo seu progresso material e moral, não cessando jamais de gritar, com toda a força do nosso entusiasmo: abaixo os governos 
dissolutos! Fora os traidores à pátria! Abaixo a aliança inglesa! Viva a soberania popular!» (O Ultimatum, n. ${ }^{\circ}$ 1, 23 de Março de 1890, p. 1).

«... Quando qualquer estudante - mesmo fora de Coimbra - se sentir extremamente incomodado com um acréscimo de ódio às instituições vigentes ou ao governo, ou a D. Carlos... não hesite um momento: sirva-se do nosso jornal como que de uma válvula de segurança, e ofereça uma parte do seu ódio à publicidade, para desabafar.

Politicamente, pois, só consentimos artigos anti-monárquicos..., fora deste âmbito, na ciência, nas letras, em qualquer assunto que interesse, todo o académico pode exercer a sua actividade, e servir-se do nosso jornal para que o público a aprecie...» (Idem, p. 2, col. 1).

\section{Conteúdo}

Trata-se de um periódico republicano, que não passou do primeiro número, e a cujo próprio título não é estranha a imposição - Ultimatum - que a Inglaterra fez a Portugal, em 11 de Janeiro de 1890, por causa da tentativa de Portugal ocupar os territórios compreendidos entre Angola e Moçambique.

Este acontecimento provocou no nosso país, uma onda muito grande de indignação e de protestos. Foi, sobretudo, ao nível dos escritores, das instituições culturais (recordamos o manifesto que os estudantes de Coimbra dirigiam ao país, em 13 de Novembro de 1890), e da imprensa republicana que as manifestações se fizeram sentir com mais violência. Não admira, por isso, que publicações estudantis apareçam espontaneamente, como reflexo de acontecimentos da vida nacional e académica. Com objectivos bem definidos e visando respostas críticas, inserem-se nesta perspectiva publicações de cunho, fundamentalmente, político e satírico. Entre outros, é o caso de O Ultimatum, que, no fundo, mais não é que um libelo acusatório contra o rei, a monarquia e o governo. Logo no primeira página, António José de Almeida é extraordinariamente contundente nos ataques que faz ao rei D. Carlos e ao regime monárquico, no artigo intitulado «Bragança, o último».

Também Afonso Costa, no artigo «A Federação Académica», dirigindo-se aos estudantes congressistas, que se reuniram, em Coimbra, nos dias 23, 24 e 25 de Março de 1890, não só responsabiliza o governo e o trono pelo atraso do país, mas também insiste na necessidade em estabelecer uma federação, para unir fraternalmente todos os estudantes portugueses, pois é necessário que es- 
tes venham a extinguir todos os obstáculos, isto é, a «derrubar a monarquia, estabelecer a república, e em seguida instruir, edificar, moralizar o povo» (p. 1, col. 5).

Críticas ao governo, também, pela pena de Albertino de Pinho, no artigo «Fora os malandros» e na escrita de A. Carvalho, em «O país vinhateiro e a crise filoxérica», pela falta de medidas, para a crise agrícola que afecta o país.

Como jornal republicano procura, igualmente, dar a conhecer a mensagem e o projecto republicano. Em «A revolução de 1890", Armando Zuniga não só defende o fim da monarquia, como divulga as ideias de uma república federativa, seja em relação à Espanha, seja com os Estados Unidos. Termina o seu artigo identificando a doutrina de S. Pedro com a doutrina de Comte. Para tal, basta substituir, naquela, os princípios do Cristianismo pelos da filosofia positivista.

Completa-se este periódico com notícias sobre a reconstrução do teatro académico, publicidade, na última página, um folhetim e poesia, onde, também, os ministros são censurados: «Os ministros actuais,/Uns famosos figurões,/ Querem com a lei das rolhas/Salvar as instituições» (p. 1, col. 5).

Face às fortes críticas vindas, essencialmente, da imprensa republicana, em 29 de Março, o próprio ministro da Justiça viu-se obrigado a legislar em matéria de liberdade de imprensa, para terminar com os ataques ao governo, à monarquia e ao rei. Assim se explica a vida efémera deste periódico, pelo consequente processo que foi movido a António José de Almeida e ao tipógrafo Pedro Augusto Cardoso, proprietário da Tipografia Operária, local onde $O$ Ultimatum foi impresso.

Bibliografia: Luís Reis Torgal, António José de Almeida e a República, Discurso de uma vida ou vida de um discurso. Selecção de imagens de Alexandre Ramires, Casais de Mem Martins, Círculo de Leitores, 2004, pp. 39-60; Alberto Sousa Lamy, A Academia de Coimbra. 1537-1990. História. Praxe. Boémia e Estudo. Partidas e Piadas. Organismos Académicos, Lisboa, Rei dos Livros, 1990, p. 600; Alice Godinho Rodrigues, «Ultimatum - Cem anos para não esquecer (1890-1990)», O Despertar, Coimbra, 26 de Setembro de 1990. 


\section{A AERDADE}

19 Março $1896^{(1)}$

Director: Barreto

Formato: $21 \times 27 \mathrm{~cm}$

Periodicidade: Não indica

Preço: 60 réis

Páginas: 4
Cotas:

$\mathrm{BN}$ : -

BGUC: -

BPMP: -

BMC: GHC -20/10

\section{Conteúdo}

Sabemos muito pouco deste periódico. Trata-se de um jornal copiografado de alunos do liceu e de que se publicaram poucos números. Na B.M.C. existe apenas o n. ${ }^{\circ}$, que apresenta algumas manchas, tornando-se, assim, difícil a sua leitura. Continuado do número anterior, é de salientar um artigo com o título de «O catolicismo e a república».

Fala-se, também, das campanhas de África. Uma breve referência aos espanhóis em Cuba.

Completa-se com um folhetim e pequenas notícias.

(1) Esta data diz respeito ao n. 3 (Cfr. Carneiro da Silva, ob. cit., p. 132). 


\section{6・A VERDADE EM TRIUNFO}

Coimbra, Na Imprensa da Rua dos Coutinhos

7 Maio 1823 - 28 Maio 1823

\section{Objectivo}

«Não foi o espírito de novidade quem nos estimulou a lançar mão da pena, nem tão pouco a em todos os tempos luciferina paixão, que ao mais lamentável estado conduziu o rico, de que nos fala o Evangelho. Nunca fomos avarentos: sempre desejamos tão somente o necessário para mantermos a vida no desempenho de nossas obrigações. Muito menos nos influiu o aparatoso nome de escritor, só o amor e predilecção que tributamos à verdade, só a glória, a impagável glória de sermos úteis à nossa cara Pátria a tanto nos arrebata, e nos faz desta arte aparecer em público; a paz, e nada mais desejamos ver estabelecida entre os portugueses, e que uma reforma mais filha dos céus, que dos homens, os fizesse entrar no conhecimento dos fins para que foram criados... Mas já que a nossa madura e pacífica imaginação nos obriga a tanto saíremos a campo não para combater gigantes...

$364 \quad O$ triste labirinto que a lembrança do passado, e de tantos erros políticos nos despertam, a vista das desgraças da nossa amabilíssima Pátria, e do mais pavoroso quadro que funestamente se nos antolha, e que nos faz estremecer, nos faria igualmente permanecer em um perpétuo silêncio, e ainda quando a nossa consciência, demais a mais, severamente não acusasse de fraqueza e cobardia, o temor de patentearmos a verdade, assim mesmo nos proporíamos a expôr os nossos mais que puros sentimentos... o amor da humanidade, a salvação da Pátria e o esplendor da monarquia tanto exige de nós, e lhe somos obrigados a prestar. 
A empresa que tentamos, e temos em vista, é assim difícil e perigosa pela diversidade dos modos, porque cada um pensa; mas como não podemos já duvidar que os diversos raciocínios até aqui produzidos por muitos sábios, de nada aproveitarão para a união dos dois continentes, manifestaremos os nossos, que quando não sejam os mais profícuos, não deixarão de utilizar em parte, e talvez façam aparecer outros, cujas ideias por mais elevados apresentem o grande plano da nossa reconciliação com os filhos do novo mundo...» (n. ${ }^{\circ}$, 14 de Maio de 1823, p.p.1-2).

\section{Conteúdo}

A Verdade em Triunfo é um pequeno periódico, de linha católica-liberal, cujo objectivo fundamental era contribuir para um estreitamento das relações entre Portugal e o Brasil.

A colecção completa desta publicação é de quatro números, todos com o mesmo formato e número de páginas.

Indo de encontro ao objectivo traçado, a temática dominante neste modesto jornal, que ostenta poucos títulos, é o apelo insistente que o seu director, um estudante brasileiro, que, reconhecendo ter havido, no passado, alguns desentendimentos nas relações entre Portugal e o Brasil, procura, agora, contribuir, na medida do possível, para uma real e efectiva aproximação dos dois povos irmãos. Fá-lo, não só na pessoa de D. João VI, de quem «o Brasil não pode deixar de lembrar-se de um Rei que tão liberalmente o encheu de graças» (n. ${ }^{\circ}$ 1, p. 1, col. 2), mas também invocando o sentido fraterno da doutrina cristã, ao questionar: «Nascemos para adorar a Deus sobre todas as coisas, e para amarmos ao próximo como a nós mesmos - e fazemos nós por cumprir este saudável fim da nossa criação? Dizei-nos Portugueses de aquém e de além-mar, portugueses obstinados em vossos defeitos, surdos às vozes do Cristianismo... haveis de perseverar tão vergonhosamente em vossos crimes?» (n. ${ }^{\circ} 4$, p. 1, cols. 1 e 2). Vai-se mais longe e chega-se mesmo a invocar o nome de Deus: «procuremos que dos Céus nos venham os traços da nossa reconciliação com o Brasil, e peçamos a Deus que nos ensine os caminhos por onde possamos acertadamente marchar...» (n. ${ }^{\circ}$ 3, p. 2, col. 1). 
No âmbito da história do Brasil, há que referir a publicação de uma proclamação do Senado do Recife, a propósito de uma certa agitação em Pernambuco.

Publica-se, também, uma declaração dos estudantes do $4 .^{\circ}$ Ano de Cânones, insurgindo-se contra o modo, pouco curial, como o jornal Minerva Constitucional se refere ao Professor José Caetano da Silva.

Completam este jornal uma descrição muito sucinta sobre a maneira como Coimbra e a Universidade festejaram o aniversário natalício de D. João VI e também poesia, alguma da qual é dedicada ao próprio soberano, pelo motivo acima referido. 


\section{7 - A VESPA}

Jornal humorístico

Coimbra, Imprensa Académica

4 Março 1877 - 4 Junho 1877
Cotas:

BN: J.326//4 P; J.965//50 P.

BGUC: $10-5$ - 19

BPMP: XI - 1 - $10(\mathrm{~A})$

BMC: GHC $-20 / 2$

Director: José de Azevedo Castelo Branco

Colaboradores: Eduardo Burnay, José Maria Barbosa de Magalhães, José Pinto de Mesquita, João Rubio, Vicente Pinheiro de Melo

Formato: 19,5 x 27,5 cm

Periodicidade: Semanal

Preço: Coimbra - 600 réis - Trimestre

Páginas: 96

\section{Objectivo}

«Depúnhamos a retórica. Não vai arreada das prometedoras frases de um programa a nossa Vespa e nisto está talvez o seu direito à vossa amiga estima.

No país, onde, desde o organizar-se de um corrilho político até à inauguração duma filarmónica em Figueiró dos Vinhos, nada se diz, nada se faz desacompanhado das declamações tradicionais da nossa índole, não ter um programa, nada prometer cousa alguma, é mais do que estranho, é ser-se quase original.

A Vespa, investindo assim com tão radicadas costumeiras, deverá porém parecer um perigo social, um torpedo armado ao incauto repouso da burguesia sensata, de que a polícia não poderá levantar mão sem o eminente risco de uma crise enorme...

A Vespa não se afirma em política senão talvez pelo lado estético. E sob tal ponto de vista não desadora a palidez romântica do Sr. Barjona, sem dispensar-se de achar que é de mais a polposa carnação do prelado de Viseu.

Do que se infere que nos não pruem cobiças de alevantadas hierarquias burocráticas que, obscurecendo-nos a plástica franzina do Sr. Braamcamp - o estítico, nos adelgaçassem a corpulência sadia do Sr. Sampaio - o rústico.

E neste meio termo, neste equilíbrio artístico é que estão firmadas as pagãs opiniões políticas da nossa hebdomadaria Vespa. Que eles, pois, se não enervem, 
que busquem na higiene da alma e na limpeza do corpo a imunidade às ferretoadas do insecto, que, ainda assim, os pouparia vendo-os verminosos a ressumar das verdes podridões.

$\mathrm{Na}$ literatura a Vespa esvoaça estonteada das relambórias endeixas de um romântico de província para as fesceninas trovas dos vates realistas... Que nos dêem o critério das modernas letras portuguesas, que esta luta asfixia-nos...

Na sua missão, qualquer que ela seja, a Vespa vestir-se-á das cores modestas dos quadros aprazíveis em que possas repousar o espírito assustado dos desperdícios fazendários dos teus ministros ou dos vulcânicos programas dos teus estúrdios repúblicos.

Nesse emmeio recebê-las-ás com agradável complacência, rirás dos seus maus ditos, terás as gargalhadas sonoras das compleições sadias para as coisas picarescas do teu meio social, colaborando assim com o teu bom senso prático na destruição das coisas risíveis e no ostracismo dos teus retóricos oficiais.

E deste modo a missão da Vespa acentuá-la-ás tu; serão filhas de ti mesmo, do teu trabalho inconsciente, as ideias práticas que colheres da leitura das suas crónicas ligeiras ou da inspecção dos quadros alegóricos» (n. ${ }^{\circ}$ 1, pp. 1-2).

\section{Conteúdo}

A Vespa é um pequeno periódico ilustrado e crítico que procura satirizar a sociedade portuguesa, em geral, e a classe política, em particular. Para além dos dizeres, em prosa e verso, fá-lo, também e muito humoristicamente, nas várias ilustrações que integram o jornal.

Compõe-se esta colecção de doze números, todos com o mesmo formato e número de páginas.

Em colunas como «Fototipias em prosa» e «Caricaturas» criticam-se, não só figuras do mundo da política como António Rodrigues Sampaio, o Marquês

de Ávila, vários deputados, os governadores civis de Braga e de Coimbra, este, em virtude de enviar circulares que se caracterizam por «um desprimor gramatical» (n. ${ }^{\circ} 12$, p. 89), mas também personalidades outras como o prestamista Bolson e, no mundo eclesiástico, o bispo do Porto e um sacerdote do Convento das Terezinhas. Alguém, ridicularizando, fisicamente, este clérigo, poetisou assim: 
«Dou-te um figo de comadre,

E afirmo que não é pôdre,

Se me disseres se o padre

Que ora prega, ó Santa Madre!

É homem, ou pança ou ôdre» (n. ${ }^{\circ}$ 2, p. 14, col. 1)

Críticas ao governo e à sua política em «Boletim Político»e, na prosa de Vasco Ascêncio (pseudónimo de José de Azevedo Castelo Branco), em «O Novo Ministério", mas também no quadro intitulado «Apresentação do Novo Ministério. Extracto da Sessão», onde o Marquês de Ávila apresenta o seu programa.

Também o jornalismo português é alvo de fortes críticas. No artigo intitulado mesmo «Jornalismo português», o seu autor categoriza os diferentes estilos jornalísticos, para, depois, melhor os criticar.

De salientar ainda neste periódico a apresentação de figuras típicas de Coimbra e as críticas aos dramas de António Enes, em «A Romaria». Veja-se a este propósito a ilustração intitulada «Ennes, o Saltimbanco e o Engeitado» (pp. 52 e 53).

Completa-se este periódico com uma «Secção Literária», onde se trata, exclusivamente, de poesia. 


\section{8 - A VIA LATINA}

Folha Semanal (1)

Coimbra, Tip. União

28 Novembro 1889 - 9 Maio 1890
Cotas:

BN: J. 1708//34 V.; J. $2459 / / 40 \mathrm{~V}$. J. $3591 / / 158$ M.

BGUC: -

BPMP: P/C/1064

BMC: GHC $-152 / 5$

Redactores: José Benevides, Caetano Gonçalves, Celestino Henriques (2)

Formato: $32,5 \times 44 \mathrm{~cm}$

Periodicidade: Semanal

Preço: Trimestre -300 réis $\bullet$ Avulso -20 réis

Páginas: 4

\section{Objectivo}

«Ser influenciado, obedecer é a lei suprema da evolução humana. Revoltem-se contra ela os filósofos, os tolos e os revolucionários, mas destruam-lhe, se podem, a verdade da realização...

É que, fundamentalmente, as acções humanas não são mais que o produto do meio.

É por isso que a Via Latina não faz programa - de todo o ponto inexequível se os redactores não tiverem o apêndice da faculdade de previsão. Mas nem os redactores têm apêndices extra-normais, nem querem seguir de futuro com o rélismo de um programa não cumprido na onda da costumeira do jornalismo indígena.

No entanto, tomem de memória as más línguas cá da terra (sem alusão ao Sr. Barros Lobo) que a afirmação da teoria mesológica é o «produto de uma

370 convicção bem funda, e não o instrumento preparado para futuras flexibilidades de espinha às imposições dos fortes».

A Via Latina só reconhece uma força - a da inteligência» (n. ${ }^{\circ}$ 1, p. 1, col. 1).

(1) A partir do n. ${ }^{\circ} 8$, inclusive, Via Latina tem como subtítulo «Jornal Académico».

(2) José Benevides deixou de fazer parte da redacção «por motivo de incompatibilidade de opiniões» (n. ${ }^{\circ} 8$, p. 1, col. 3). 


\section{Conteúdo}

Recusando adoptar qualquer programa, mas atenta ao que se passa à sua volta, cá dentro e lá fora, A Via Latina faz eco, não só de notícias e acontecimentos nacionais e estrangeiros, mas fundamentalmente do pulsar da vida académica, da comunidade estudantil, seus projectos e preocupações. A Via Latina é, assim, uma fonte de grande importância para a história da Academia de Coimbra e da própria Universidade.

Compõe-se esta primeira série de $A$ Via Latina de doze números, todos com o mesmo formato e número de páginas. A estrutura interna é sensivelmente a mesma ao longo da colecção. Ao contrário do que acontece com outros periódicos, não existe um artigo de fundo a dominar a primeira página. Predominam textos e artigos, de natureza bastante diversa, alguns mesmo sem qualquer título.

Nutrindo algumas simpatias pelas ideias republicanas e vivendo-se em Portugal uma conjuntura política exacerbada, em virtude do Ultimatum que a Inglaterra impôs a Portugal, em 11 de Janeiro de 1890, um dos temas mais importantes e que dominam neste periódico é, sem dúvida, o debate e o posicionamento da academia em torno desta questão. A testemunhá-lo, um conjunto de textos e artigos como, por exemplo, "A tendência inglesa», "A grande subscrição nacional», "A questão Crawford», «O movimento académico» e «Indústria e Marinha Portuguesa», entre outros. Também ao nível da poesia esta questão não passou despercebida. Aqui se sente, também, a mesma repulsa e o mesmo sentimento antibritânico, de que são exemplos, entre outros, os poemas: «Ódio ao inglês» e «Canalhas».

É à volta desta temática que se fazem referências e considerações a Portugal e às colónias; se historia a posse dos territórios a norte e sul do Zambeze e as pretensões inglesas; se debate a questão africana e se tecem fortes e contundentes críticas à Inglaterra, porque, ao contrário da França que «empregava somente a guerra» (n. ${ }^{\circ}$ 3, p. 2, col. 2), a Inglaterra «usa de todos os processos mansos e ocultos, que a falta de escrúpulos pode sugerir» (Idem); da importância da Liga Patriótica do Norte e da grande subscrição nacional, porque os governos só consomem os dinheiros públicos.

Para além de notícias diversas sobre o protesto dos académicos contra a Inglaterra, anote-se a publicação da mensagem enviada pela academia ao ministro da Guerra; as mensagens de apoio que os estudantes de Coimbra receberam 
dos seus colegas espanhóis de Santiago de Compostela e de Madrid; o fracasso dos esforços desenvolvidos para a expulsão do cônsul inglês da cidade do Porto e, sobretudo, a constatação do pouco interesse manifestado pelas autoridades no levantamento do espírito nacional, face ao ultraje sofrido, o que levou os académicos a dizer: «Nós saímos do paço convencidíssimos de que o mal estava alí» (n. ${ }^{\circ}$ 10, p. 1, col. 4).

Uma outra temática, à qual não é totalmente alheia a conjuntura política vivida, é a do associativismo estudantil, nomeadamente, a criação da Federação Académica Portuguesa, cuja grande finalidade era «promover a renascença social portuguesa», que passava por vários desmembramentos, nomeadamente, $\mathrm{o}$ «nacionalizar o comércio e acabar completamente com a importância inglesa» (Cfr. Estatutos da Federação Académica Portugueza, Coimbra, 1890, p.p. 3-4). Para além de notícias dispersas é em textos e artigos como «O princípio da Associação Académica», "A nossa atitude» e «Fraternitas», por exemplo, que esta temática é assumida. Aqui se dá conta do movimento associativo académico francês; se critica o governo de Portugal pela atitude que tomou ao dissolver a Associação Académica de Lisboa (transcreve-se a mensagem que a Academia de Coimbra enviou aos estudantes de Lisboa, numa atitude de solidariedade e de simpatia); dão-se notícias da reunião que houve, no Porto, onde se aprovaram as bases da Federação Académica de todos os estudantes portugueses, a qual será «um corpo que para o futuro há-de ser tido em conta na solução das questões vitais da nossa pátria» (n. ${ }^{\circ} 7$, p. 1 , col. 1 ) e, finalmente, da aprovação dos seus estatutos, o que se verificou, em congresso, em Coimbra, nos dias 23, 24 e 25 de Março de 1890 (Publicam-se os Estatutos).

Para além destas duas grandes temáticas, encontramos em Via Latina outras questões e problemas, de natureza e importância muito diversa, que sintetizamos assim:

- Questões e factos académicos:

- As assembleias gerais da academia - o que são e como decorrem?

- Problemas de habitação - as condições desconfortáveis em que muitos estudantes vivem, em «excêntricos ménages a que a tradição conserva o nome de repúblicas» (n. ${ }^{\circ}$ 5, p. 1, col. 2) e as epidemias

- Teatro Académico - o projecto do novo teatro académico, seu autor (Nicola Bigaglia) e obras (publica-se uma carta de Emídio Navarro para António Luís Gomes, presidente da Associação Académica). 
- A Tuna de Salamanca em Coimbra

- Récitas de despedida

- Faculdade de Teologia - contributo para a sua história (referências à Memória escrita pelo Dr. Jacinto Fragoso; às relações Estado/Igreja; defende-se a ideia de que a superintendência sobre o ensino deve pertencer ao Estado

- Agruras de um estudante - a pouca simpatia que Diógenes (pseudónimo de António José de Almeida) tem pelo estudo da matemática

\section{- História do Brasil:}

- O movimento político brasileiro - causas do seu êxito; deseja-se para o Brasil que «o momento histórico que o atravessa seja não revolucionário mas evolutivo» (n. ${ }^{\circ}$ 1, p. 2, col. 1)

- A proclamação da república no Brasil

- Reacções em Portugal - noticia-se um jantar republicano onde estiveram presentes vários estudantes de Coimbra. Citam-se os seus nomes (Cfr. n. ${ }^{\circ}$ 2, p. 3, col. 2).

\section{- Política/Imprensa}

- A morte de D. Luís e as exéquias na capela da Universidade

- Críticas à política monárquica que «entre nós já não toma caminho» (n. ${ }^{\circ}$ 1, p. 1, col. 3)

- A questão ibérica - a federação ibérica

- Partido republicano - a vitória dos candidatos republicanos em Lisboa

- Política e imprensa

- A questão da liberdade de imprensa

Completam esta publicação um artigo de Caetano Gonçalves intitulado «Crítica. Realismo na Arte», algumas poesias e notícias várias de Coimbra, da Academia e até do estrangeiro. 


\section{$139 \cdot 21$ DE MARCCO}

Número único comemorativo da festa final do Curso

Cotas:

do quinto ano jurídico de 1884-85

Coimbra, Imprensa Progresso

BN: -

BGUC: -

21 Março 1885

BPMP: -

BMC: GHC $-20 / 4$

Colaboradores: Abel Augusto Garção, Abílio Braga, Agostinho de Almeida Rego, A. Toscano Júnior, Costa Macedo, Solano de Abreu, Francisco

Ferreira da Silva, Cardoso Pimentel, Jacinto José Tavares, José Lopes Ferreira dos Santos, Sebastião Horta, M. L. Coelho da Silva, F. Augusto Martins Vicente, Júlio de Lemos Macedo, Cupertino de Andrade, Fernandes Pinto, Santos Melo e José Maria de Figueiredo

Formato: 23,5 x $32 \mathrm{~cm}$

Periodicidade: N. ${ }^{\circ}$ único

Preço: Não indica

Páginas: 8

\section{Objectivo}

Não indica

\section{Conteúdo}

Como o subtítulo refere, trata-se de uma publicação de comemoração. No caso, a despedida do 5. Ano jurídico de 1884-85. De uma maneira geral, este tipo de publicações caracterizam-se por serem números únicos e nelas colaborarem vários estudantes. De salientar também que, normalmente, estas publicações não ostentam qualquer preçário. Ou são gratuitas ou cada comprador poderá contribuir com aquilo que entender, uma vez que o produto das vendas reverte a favor de instituições de beneficência, que, aqui, é a Sociedade Filantrópico-Académica. Assim, no dizer de Sebastião Horta, o 5. ${ }^{\circ}$ ano jurídico cumpre «a missão de caridade para com aqueles que precisam do seu auxílio, afim de progredirem nos caminhos da ciência e da civilização» (p. 6, col. 2). 
Para além de uma certa produção literária, em textos de prosa (contos e romances) e verso (publicam-se os versos recitados na festa de despedida do $5 .^{\circ}$ ano jurídico), neste pequeno jornal descrevem-se, também, breves quadros da vida académica: pequenas alusões da chegada do novato a Coimbra, referências à boémia e à praxe e, por fim, o adeus a Coimbra e o terminar da vida de estudante, que levaram A. Toscano Júnior a dizer: «ao despirmos a capa e batina para envergarmos outros hábitos, que profunda saudade!... que crítica situação!» (p. 2, col. 2).

De salientar, finalmente, breves reflexões, em pequenos artigos sobre questões como: liberdade de imprensa; recrutamento militar e a Humanidade através da História. 


\section{$140 \cdot$ VOZ DO PORVIR}

Hebdomadário Republicano

Coimbra, Tip. e Lit. Minerva Central

7 Março 1897 - 2 Maio 1897
Cotas:

BN: J.774//47 A.; J.1689//9V.

BGUC: -

BPMP: -

BMC: GHC -152

Editor: José Maria dos Santos Nazaré

Redactores: Artur Anselmo Ribeiro de Castro, José Nepomuceno Fernandes Brás e João Vitorino Mealha

Colaboradores: Alexandre de Matos, Patrício Judice, Gonçalves Cerejeira, Fazenda Júnior, Jacinto Maia, A. Feliciano Rodrigues

Formato: $30,5 \times 45 \mathrm{~cm}$

Periodicidade: Semanal

Preço: Trimestre -400 réis

Páginas: 4

\section{Objectivo}

«Na corrupção da sociedade e no esfacelamento das instituições, impõe-se uma reforma imperiosamente, e exige-se que corações ainda jovens e ardentes saibam, pela propaganda e pelo doutrinamento, apressar os giros da evolução.

Vimos, com o peito pujante em amor, em procura de um ideal, ainda há pouco envolto em trevas de obscurantismo, mergulhado sob o peso imenso duma injusta opressão, mas que hoje se nos apresenta já próximo, espalhando a economia e aconselhando a moralidade, procurando o bem-estar dos povos e elevando as nacionalidades.

Somos jovens, mas independentes; vivemos sob o peso odioso da repressão

376 mas ambicionamos a liberdade. E levados pelo sangue, e impulsionados pela natureza lançamo-nos hoje nas já vastas fileiras em que a liberdade dos povos é um lema, e as instituições republicanas um ideal próximo à prática.

Com este fim, com esta única mira, pegamos na pena como meio de divulgação e propaganda, ensinando que a natureza protesta contra a escravidão, que o sagrado tema da liberdade foi uma constante aspiração que precisa de ser reduzida à prática e não um mero termo de que impunemente se zombe, que constantemente se conspurque com afrontas e se ludibrie com mentirosas promessas. 
Ensinaremos a todos a maneira de preparar o futuro, mas um futuro em que a honra não seja um mito, nem a moralidade objecto de escárnio; em que a economia não seja, como é hoje, sinónimo de desperdícios inúteis e funestos, nem o trabalho causa de desdens e vilezas...

Somos académicos, e como académicos saberemos viver...

Foi para nos animar a procurar a ventura, a divinizar a Liberdade: eis o que fazemos, eis o lema da Voz do Porvir» (Voz do Porvir, n. ${ }^{\circ}$ 1, Coimbra, 7 de Março de 1897, p. 1, cols. 1 e 2).

\section{Conteúdo}

Voz do Porvir é um pequeno jornal organizado por estudantes republicanos do qual saíram apenas sete números.

A primeira página é dedicada ao artigo de fundo e um ou outro texto, seguindo-se, depois, um conjunto de outros temas e rubricas várias.

De uma maneira geral, os artigos de fundo, da responsabilidade da redacção, centram-se numa forte crítica ao regime monárquico, porque «a monarquia é a imunda chaga que nos consome e nos degrada» (n. ${ }^{\circ} 1$, p. 1) e à má política dos governos que «com as suas torpezas, a sua desmoralização, os seus desvarios, a sua falta de patriotismo» (Idem), nos conduzem ao abismo.

Num ou noutro destes artigos é ainda notório, sobretudo na sua parte final, um discurso de esperança, na apologia que fazem da República que é entendida como «recurso único e seguro» (n. ${ }^{\circ}$ 3, p. 1), para a nossa «Salvação».

Desdobrando temáticas é possível identificar as seguintes questões:

- Republicanismo: Partido Republicano - organização; manifesto republicano de Silves;

- Vida Académica: resposta do Dr. Guilherme Moreira a João Franco por aquele ter sido prejudicado na sua nomeação para professor catedrático da Faculdade de Direito; protesto de João de Freitas ao Conselheiro José Luciano de Castro por aquele ter sido preterido na ocupação de uma vaga do $4 .^{\circ}$ Grupo, no ensino secundário; mensagem que os estudantes portugueses enviaram ao povo grego; recepção, em Coimbra, à Academia de Lisboa (o n. ${ }^{\circ} 5$ é dedicado exclusivamente a este assunto); o aparecimento, em Coimbra, de uma nova revista «A Social»;

- Defesa da Liberdade: textos relativos à Grécia, Brasil e imprensa republicana; 
- Questão Social: greves;

- Algumas considerações sobre a nossa ortografia.

Completam este periódico um conjunto de notícias várias, alguma poesia e um folhetim. 


\section{$141 ・$ O VULGÃO}

Justo e Crítico

Coimbra, [s.l.]

26 Outubro 1884
Cotas:

BN: -

BGUC: -

BPMP: -

BMC: GHC $-19 / 2$

Formato: $11 \times 16,5 \mathrm{~cm}$

Periodicidade: N. $^{\circ}$ único

Preço: Não indica

Páginas: 2

\section{Objectivo}

«Meus Senhores, Minhas Senhoras

Quando em 1284 a tropa holandesa subiu ao trono era eu então vice-reitor da Universidade Espanhola. Agora que sou mais novo que então já não o sou. Querem saber porquê? Porque deixei de o ser. Não obstante ainda me acho com fraqueza para empreender uma publicação semanal, com que me divertirei à custa de mim e dos outros» (n. ${ }^{\circ} 1$, p. 1$)$.

\section{Conteúdo}

Trata-se de um jornal manuscrito, número único, cuja finalidade era ridicularizar o Prof. Pedro Augusto Rocha. 


\section{2・ZABUMBA}

Diário de poesia a todo o transe

Coimbra, [s.l.]

1 Maio 1871 - 6 Maio $1871^{(1)}$
Cotas:

BN: -

BGUC: -

BPMP: -

BMC: GHC - 4

Director: João Penha

Formato: 14 x 20,5 cm

Periodicidade: Não indica

Preço: Não indica

Páginas: Não indica

\section{Conteúdo}

Trata-se de um modesto periódico litografado que, utilizando a forma poética, graceja, humoristicamente, de figuras de Coimbra, nomeadamente lentes e estudantes. Assim:

«Tamagnini da Encarnação

Poros na ponta do nariz

O colorido feliz

D’uma rosa do Japão»

Um outro exemplo com o título «Pregão»

«Bradava um homem na feira

- Há por ahí alguém que merque

Vassoiras da bigodeira

380

De Bernardo d'Albuquerque»

Bibliografia: Álvaro Júlio da Costa Pimpão, «Algumas notas sobre a estética de João Penha», Biblos, vol. XV, tomo II, Coimbra, Coimbra Editora, Ld a, 1939, p. 552.

(1) A. Carneiro da Silva, ob. cit., p. 137. 


\section{3・ZÉ P'REIRA}

Coimbra, Imprensa Académica

12 Março 1881 - 24 Março 1881

Redactores: António Feijó, Eduardo de Abreu e Sérgio de Castro ${ }^{(1)}$

Formato: $33,8 \times 47 \mathrm{~cm}$

Periodicidade: Não indica

Preço: 20 réis

Páginas: 4
Cotas:

BN: J.775//60 A.; BGUC: J.1689//22 V.; J. 3593 M.

BPMP:

BMC: GHC -152

\section{Objectivo}

«Nem um distúrbio, nem um motim, nem sequer uma desordem sem importância, veio perturbar a grave compostura e a seriissima atitude que os estudantes de Coimbra tomaram em frente do proceder virulento e tumultuário do Sr. José Pereira Pinto. E é talvez único, na história da vida académica, este caso de a Academia, em luta com a autoridade, não ter recorrido a excesso algum, e ter-se mantido estritamente dentro do protesto veemente, mas legal.

A conservação, porém, apesar da ofensa feita à Academia, e dos protestos desta, e a despeito de todas as conveniências de ordem e segurança pública, do Sr. José Pereira Pinto dos Santos à testa da administração superior deste distrito, obriga e compele a Academia a manter-se firme e inquebrantável no posto de honra a que os seus brios a levaram, e a não desprezar meio algum dos que podem fazer vingar o seu nobre propósito de obter para a sua dignidade e para os seus direitos solene e publicamente ofendidos uma pública e solene reparação.

É este o elevado motivo que nos traz ao jornalismo. Esta folha não é de indivíduo algum, nem de nenhuma parcialidade. Nem serve paixões facciosas nem obedece a misteriosos impulsos. Não há nada de maquiavélico aqui. O nosso programa é franco e claro: somos o orgão da Academia, de toda a Academia,

(1) Cfr. Carneiro da Silva, ob. cit., p. 137. 
podemos altivamente dizê-lo, e o nosso escopo é a desforra indispensável que exige o decoro académico conspurcado, e o castigo da autoridade que tão inepta e duramente nos desconsiderou...

A política não tem aqui lugar... o que nós reclamamos é que nos reparem uma ofensa brutal e injustificada, e que seja punido o funcionário que transgrediu a lei e traiu os deveres mais elementares do seu cargo" (Zé P'reira, $12 \mathrm{de}$ Março de 1881, p. 1, col. 2).

\section{Conteúdo}

Este pequeno periódico, do qual saíram dois números, aparece para dar resposta ao conflito que, em finais de 1880 e primeiros meses de 1881, opôs a Academia ao então governador civil de Coimbra, o Dr. José Pereira Pinto dos Santos. As desinteligências entre o governador e a Academia surgiram por causa da prisão de um estudante inocente.

Vieram, depois, a agudizar-se por excessos por parte das autoridades.

Este conflito deu mesmo origem a uma campanha chamada a Zé Pereirada (onde se insere este periódico), que pedia a exoneração do governador. Criouse ainda uma sociedade secreta de treze membros, cuja finalidade era raptarem o governador. Tal não chegou a acontecer, por este ter sido demitido com a queda do governo (Cfr. Trindade Coelho, In Illo Tempore, Pub. Europa-América, n. ${ }^{\circ} 287$, p.p. $\left.84-93\right)$.

Este conflito chegou mesmo a ser discutido na Câmara dos Deputados. Este periódico reproduz na íntegra, essa mesma discussão. Dá-nos também uma narração dos factos.

O número dois do jornal é em verso. Com o título de «Requiescat in pace!», canta-se a saída de Coimbra do Zé Pereira:

«Hoje que vais partir, adeus, meu caro Zé!

Agarra-te à sovela, ao cabedal, ao pez,

E deixa para sempre a vara do poder,

Por que eu sei muito bem que tens para comer

(Idem, n.o 2, 24 de Março de 1881) 


\section{$144 \cdot$ ZUMBIDOS}

Chronica mensal

Coimbra, Imprensa Literária

Março 1880 - Abril 1880
Cotas:

BN: J.1258 B.;H.G. 10643 V.

BGUC: $10-13$ - 1

BPMP: V'-8-74

BMC: GHC -2

Responsáveis: Ego e Alter, (pseudónimos de Luís de Magalhães e Carlos Lobo de Ávila)

Formato: 11,3 x 15,5 cm

Periodicidade: Mensal

Preço: 200 réis

Páginas: 80

\section{Objectivo}

«Nós, querido leitor, nem fazemos programa nem te pedimos benevolência. Apresentando-nos diante de ti só te suplicamos uma coisa - que nos leias.

Nós somos dois sujeitos obscuros, cujos nomes tu não tens visto nos jornais, cujos peitos preferem às veneras rutilantes as violetas perfumadas, mas enfim, que sentimos um prurido de mostrar ao país que se pode ser sensato sem se ser comendador.

Em face das nossas instituições nós não nos armamos do camartelo demolidor, não nos atiramos à Carta como $\mathrm{S}$. Tiago aos mouros, ... não atacamos rudemente os primeiros magistrados nem os grandes homens da nossa pátria. Oh! Não... Nós, em volta desse grupo pacato das instituições e dos homens do nosso país, vamos simplesmente levar os zumbidos dumas pequenas ironias aladas, inofensivas, sinceras e de algumas modestas verdades, que poderão ser impertinentes, como um zumbido importuno, mas que nunca serão malévolas.

Nós queremos contudo declarar-te amigo leitor, que... nem militamos em nenhum partido político, isto é, que temos educação e independência.

A nossa linguagem não será talvez primorosa... As nossas ideias não serão novas, mas serão sãs e independentes...

Os nossos Zumbidos tanto hão-de importunar os ouvidos conservadores do Sr. Fontes, como o timpano constituinte do Sr. Dias Ferreira. O Sr. Braamcamp é quem está de melhor partido porque nos há-de ouvir menos. A culpa, po- 
rém, não há-de ser nossa... Quem o há-de salvar é o seu aparelho auditivo. Para alguma coisa há-de servir o ser surdo.

O nosso critério é todo moderno, todo oposto ao carácter metafísico das fiç̧ões que nos regem...

Em arte, sinceramente preferimos Eça de Queirós...Isto não implica uma completa aderência a todos os desvarios de neo-realismo, o que significa é um protesto contra o estertor idiota do romantismo moribundo.

As nossas convicções filosóficas levam-me a estas conclusões estéticas. A exploração lamurienta e perniciosa dos falsos aspectos da vida e dos deletérios devaneios de fantasias alucinadas, queremo-las nós substituída pela observação severa e pela análise rigorosa dos complexos fenómenos da actividade biológica e social.

E assentes estas explicações, e trocado um cordeal shake-hands com esse grande amigo colectivo, que é a suprema consolação do escritor - o público, comecemos a nossa tarefa. Que ele nos proteja, e sobretudo, repetimos, - que ele nos leia» (Zumbidos, n. ${ }^{\circ}$ 1, Março de 1880, pp. 5-9).

\section{Conteúdo}

Quando os redactores de Zumbidos escrevem, nas palavras que dirigem aos leitores, que «o nosso critério é todo moderno, todo oposto ao carácter metafísico das ficções que nos regem» (Zumbidos, n. ${ }^{\circ} 1$, p. 7 ), isto mais não significa que afirmarem-se como positivistas.

O ideário de Comte entendia a sociedade como uma realidade total. Daí a insistência na sua doutrinação e o papel fundamental que, neste contexto, cabe à ideologia.

A crença em que a verdadeira transformação e reorganização da sociedade tinha de passar pelos axiomas da ciência não podia deixar de provocar algumas rupturas e evoluções. Daí, também, um empenho em transformar mentalidades.

Como revista positivista que é, Zumbidos reflecte todas estas preocupações. As questões abordadas ao longo dos dois números editados repartem-se pelos seguintes temas:

- Um primeiro grupo de textos diz respeito à dimensão do que se entende por espírito público ou opinião pública de um país, para se concluir que é «a ideia predominante entre a maioria da população sobre a política, a ciência, a 
filosofia, a literatura, a indústria, etc., manifestada pelos actos externos correspondentes - o sufrágio popular, a instrução, a moralidade, as leituras favoritas, o género de trabalho, etc» (n. ${ }^{\circ} 1$, p. 10).

Comparando Portugal com a França, verifica-se que enquanto em França «o espírito público tende... para o positivismo» (Idem), Portugal «não tem uma opinião pública de vistas largas, de ideia determinada e convicta. Ela não tem religião definida na crença, não tem filosofia definida, não tem tendência artística definida, não tem indústria definida, não tem política definida, não tem nada de definido - à excepção da ignorância e da indiferença» (Idem, p. 20).

- Um segundo grupo de textos e artigos de natureza essencialmente crítica e doutrinária:

- Textos de crítica política: ao regime em si que apelidam de «geringonça constitucional» (p. 38); aos partidos políticos que apostados na prática da «empenhoca» são denominados, ironicamente, de «partido dos sogros» (p. 27) e de «bandos políticos» (p. 38); aos deputados que sabem muito pouco e que como António Cândido, a quem chamam «positivista granjola» (p. 39), vão "para a câmara reforçar com o seu auxílio e animar com o prestígio da sua palavra, a defesa cavilosa de um ministro, que advogou todas as violências, todas as viciações eleitorais, que são o veneno corrosivo que inquina o sistema representativo, e corrompe e perverte moralmente o país» (p. 39); aos inquéritos parlamentares, "para se provar a inocência daqueles de quem ninguém dúvida» (n. ${ }^{\circ}$ 2, p. 56) e ao governador civil de Lisboa que identificam com o «celebérrimo intendente Pina Manique» (Idem, p. 47), pelas medidas repressivas que tomou na capital, para manter a ordem pública durante a noite.

- Textos de crítica à religião católica e à acção do clero: se a religião é «hoje, no estado actual da sociedade, absolutamente improfícua, para o fim de moralizar, de conter, de educar, de organizar» (n. ${ }^{\circ} 1$, p. 56), se a religião é vista como «um agente de repressão moral... um freio» (p. 61), também o clero, hoje, não tem razão de ser, porque o seu «período passou: já depois dele veio o da metafísica, que, pela sua vez, também está a render a alma ao Criador. Agora é o nosso, o período positivo: é a vez da concepção filosófica, que o Dr. Garcia tão brilhantemente defende» (p. 54). A decadência do sentimento religioso que os teólogos pensam existir, mais não é, na óptica dos positivistas, que «um sinal evidente de renovação" (p. 57).

Publicam-se, também, textos relativos à arte e literatura: critica-se, na pessoa de Pinheiro Chagas, a escola romântica e defende-se a escola realista e naturalista, na medida em que «o realismo não é uma simples mania literária 
de alguns cérebros desvairados. O realismo é uma manifestação lógica do espírito das sociedades de hoje» (n. ${ }^{\circ} 2$, p. 12).

Completam a estrutura desta revista um texto de carácter moralizante (critica-se a comissão encarregada de organizar no Porto, as comemorações do Tricentenário da morte de Camões, por pretender levar à prática um concurso de beleza feminina, para, depois, se defender a família e uma educação especial para a mulher); notícias sobre estas mesmas comemorações na Academia de Coimbra; apreciação crítica do livro Contos de Aldeia de Alberto Braga e notícias ainda sobre o modo como esta revista foi recebida pelo público. 